Historic, Archive Document

Do not assume content reflects current scientific knowledge, policies, or practices. 


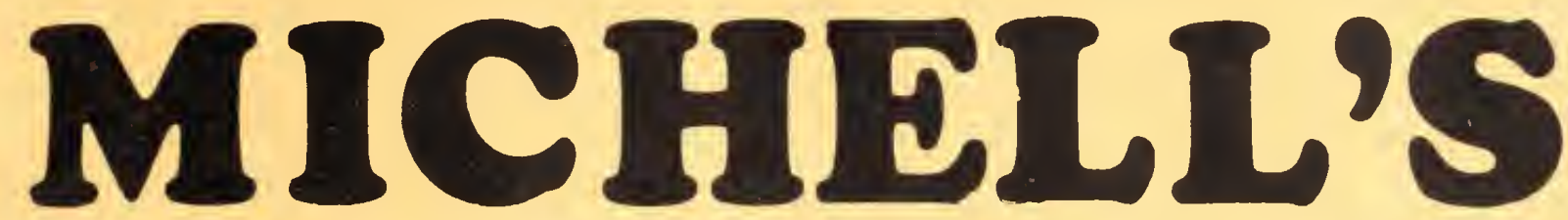

Wholesale Catalogue I93

\section{BULBS, SEEDS, PLANTS} Supplies for Florists and Market Gardeners

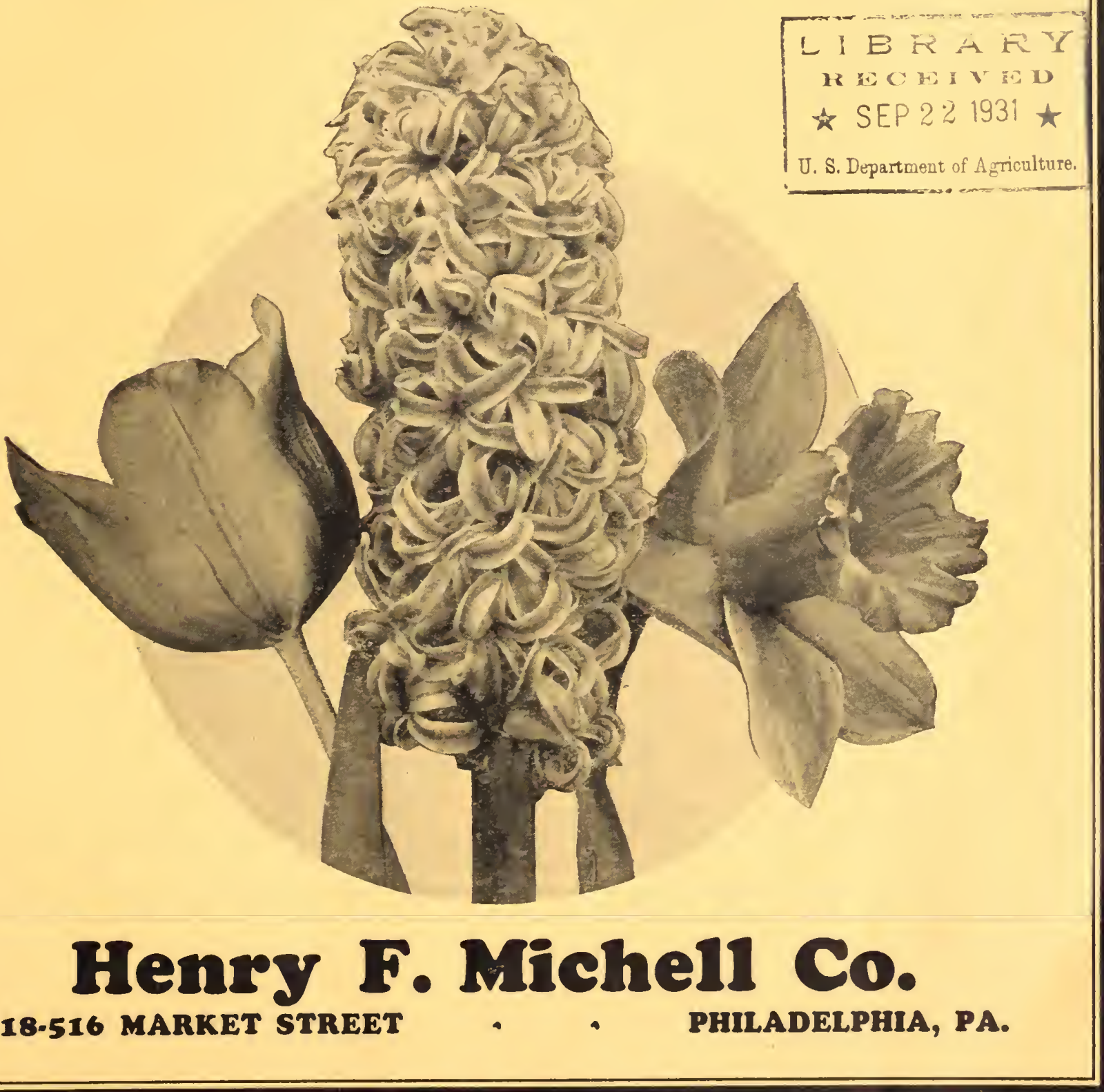


PLEASE NOTICE

Orders at prices in this catalog will be filled only for those engaged in the florist, landscape gardening and market gardening business, or others entitled to such prices. We reserve the right to refuse to fill orders for otbers not entitled to tbese priees.

As a protection to our customers who are entitled to wholesale or florists' prices we ask that they do not lend this catalog to peryons not entitled thereto. It will save us considerable embarrassment. Tell them to send for our "Seed Book"-Free upon request.

\section{NOTICE TO CUSTOMERS OUTSIDE}

OF THE UNITED STATES

In remitting for purchases at the time of ordering, or when paying accounts, by reason of the Exchange we ask that you please send P. O. Money order in U. S. Funds or a check or draft on a New York or Philadelphia Bank in par U. S. Funds.

\section{WE ESPECIALLY INVITE}

CIIARGE

A charge account is more convenient than to remit for each order at the time it is sent us; you pay no more for your goods by reason of this accommodation. As to our responsibility, we refer you to Dun's or Bradstreet's Mercantile Agency or any bank or trust compauy

When scnding your first charge order, refer preferably to someone in either your own or our line of business witl whom you have a charge account. This frequently saves delay.

\section{DISCOUNTS}

On bilts for Flower Seeds, Vegetable Seeds and Bulbs, a discount of $2 \%$ for payment 10 days from date of bill may be deducted $5 \%$ cash discount is allowed on all orders of Flower Seeds and $3 \%$ cash discount on all orders of Vegetahłe Seeds and Bulbs wheu remittance accompanies the order, unless on items specially

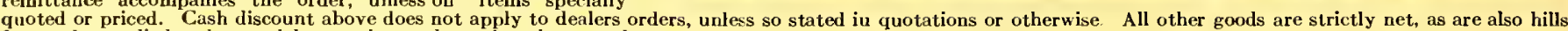
for goods supplied under special quotations unless otherwise agreed upon.

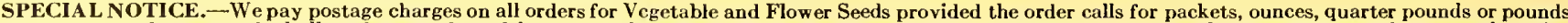

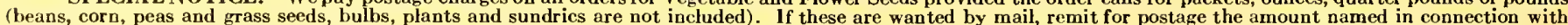
the item up to and including the third zone; for other zones add additional postage All postage is charged on dealers orders regardless of items ordered.

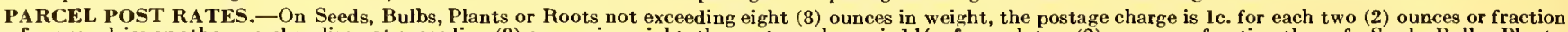

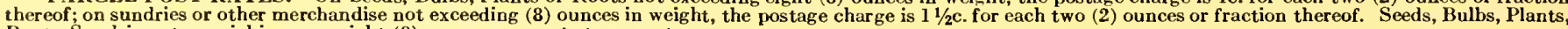
Roots, Sundries, etc., weighing over eight (8) ounces, are sent at zone rates.

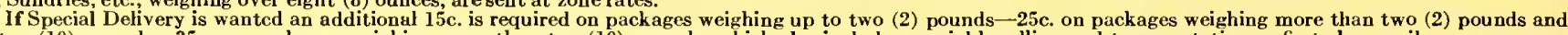
up to ten (10) pounds-35c. on packages weighing more than ten (10) pounds, which also includes special handling and transportation as first-class mail.

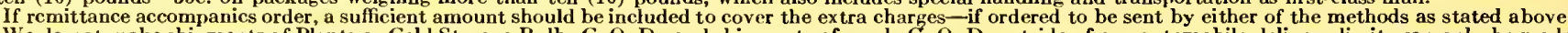

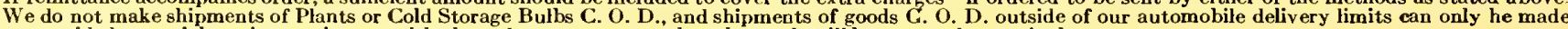
that way provided a partial remittance is sent with the order to guarantee that the goods will be accepted on arrival.

IMPORTANCE NOTICE.-All shipments of plants, perishable stock and cold storage bulbs are made at buyers' risk only.

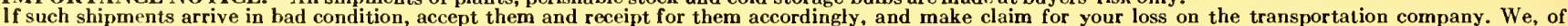

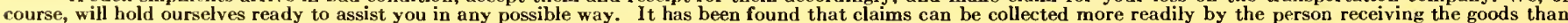
by the shipper.

Our custom to guarantee the actual arrival of goods (except at points where there is no freight or express agent), will still he continued, and claims for loss or non-arrival of merchandise not perishable will, as in the past, be carcd for hy us, so you run no risk of having to make claims for lost goods.

\section{CONDITIONS OF SALES}

All contraets, sales and acknowledgments of orders are contingent upon crop failures, our ability to import and make deliveries in conformity with the "Plant Quarantine Act,"partial deliveries by growers or manufacturers. strikes, or otber unavoidable causes beyond our control, clerical errors ineluded; also unsatisfactory creditstanding. All quotations are subject to market changes and goods being unsold on receipt of order. Ilenry F. Michell Co. give no warranty, expressed or implied, as to the deacription, purity or productiveness of any seeds, plants or bulbs they send out, and they cannot be in any way responsible for the crop. If the customer does not accept the goods on tbese terms, be must notify us at once, and we will give instructions for disposition of goods.

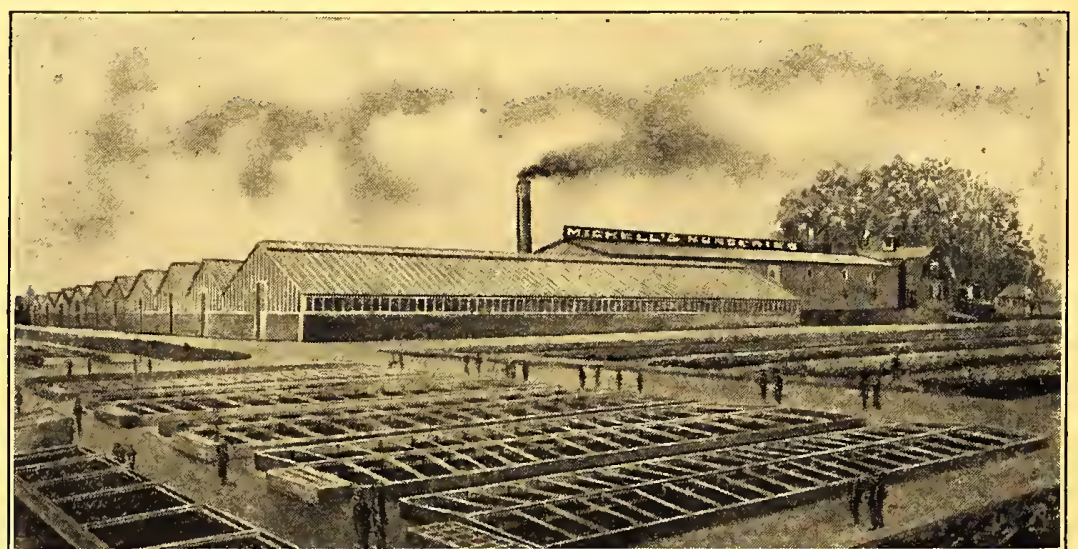

Please note parcel post charges quoted by us are for delivery in the United States only. HENRY F. MICHELL $\left\{\begin{array}{l}\text { PRESIDENT } \\ \text { SECRETARY }\end{array}\right.$

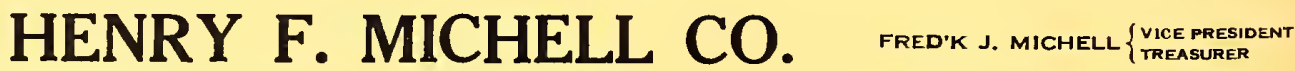

SEEDS BULBS, PLANTS, GARDEN SUPPLIES, FLORISTS' SUPPLIES,
518-516 MARKET ST., PHILA.

NURSERIES AND PLANT HOUSES, ANDALUSIA, PA.
BELL AND KEYSTONE

TELEPHONES 


\section{HENRY F. MICHELL CO. S18-516 MARKET STILADELPHA, PA,}

L.

Zone

Ship to

NAME $\overline{\text { Please prefix Mr.. Mrs. or Miss }}$

Street-

Date

193

Post Office.

P. O. Box

R. F. D. No

Please DO NOT Write

in This Space

Freight or Express Address.

County.

If Different from P.O.

State

Charge to

Charge Address

\begin{tabular}{|c|c|c|c|c|c|c|c|}
\hline 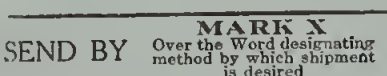 & FREIGHT & EXPRESS & BOAT & $\begin{array}{l}\text { PARCEL } \\
\text { POST }\end{array}$ & $\begin{array}{l}\text { BAGGAGE } \\
\text { MASTER }\end{array}$ & $\begin{array}{c}\text { LOCAL } \\
\text { EXPRESS }\end{array}$ & DELIVERY \\
\hline
\end{tabular}

PRICED BY

ORDER

FILLED BY

DATE

FILLED

DOUBLE

CHECKED BY

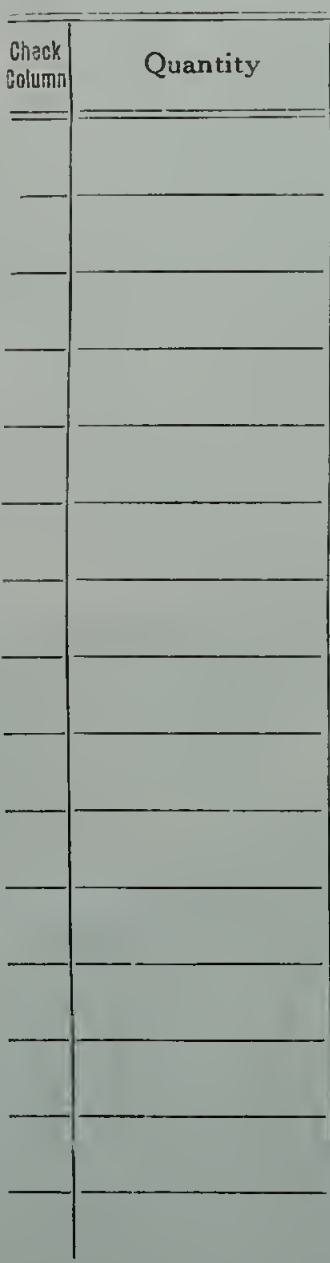

\begin{tabular}{|c|c|c|c|c|c|}
\hline Veg. Seeds & Flo. Seeds & Bulbs & Plants & Tools & Sundries \\
\hline & & & & \\
\hline & & & &
\end{tabular}

Insect.

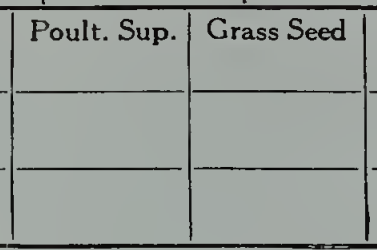

Fertil.

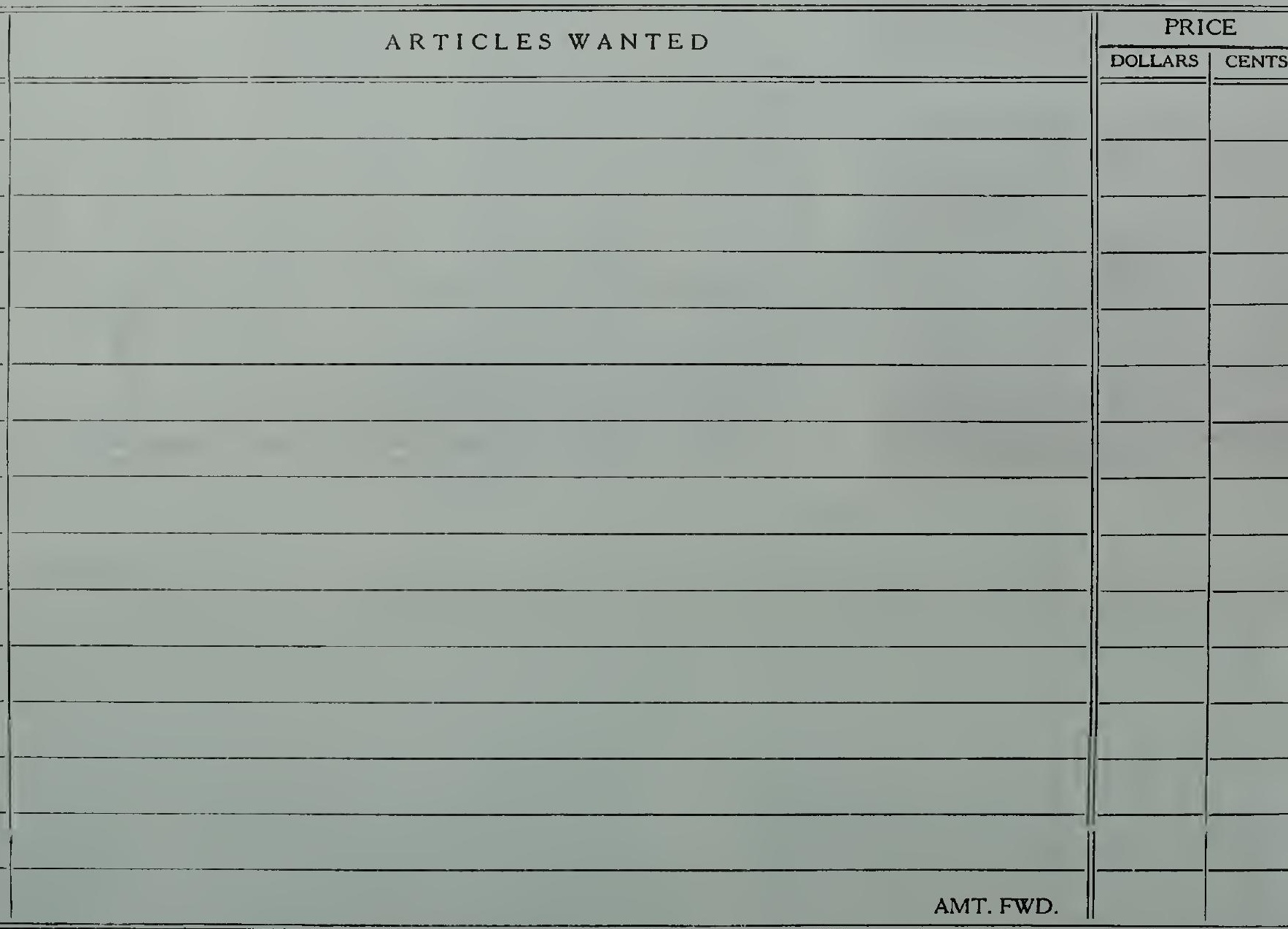

HENRY F. MICHELL CO. give no warranty, expressed or implied, ae to the description, purity or productivenese of any seeda, plants or bulbs tbey mend out and they cannot be in any way responsible for the crop. If the customer does not accept the goods on these terino, they can be returned at once. 


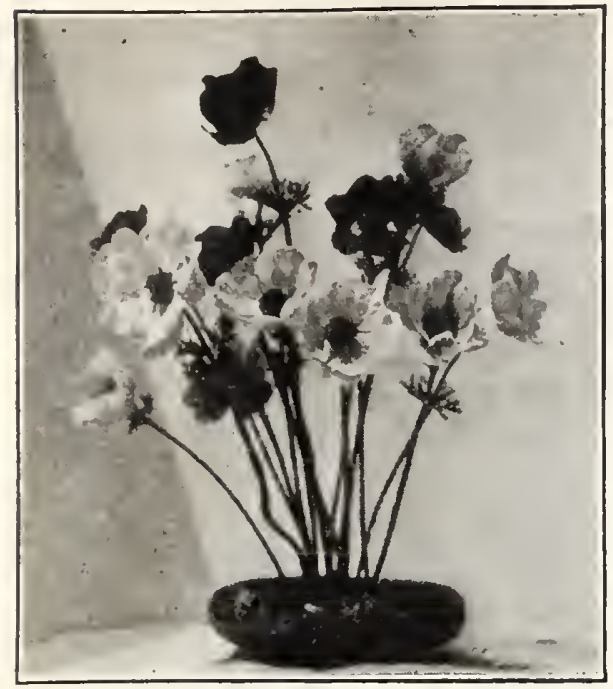

Anemone

The varieties on this page have been selected as specialties that are real profit providers for the florist.

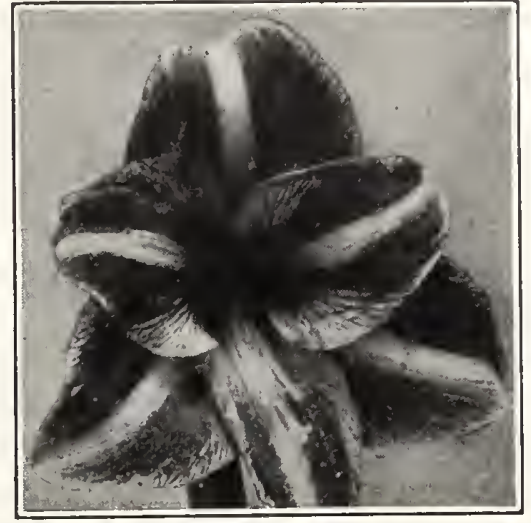

Amaryllis

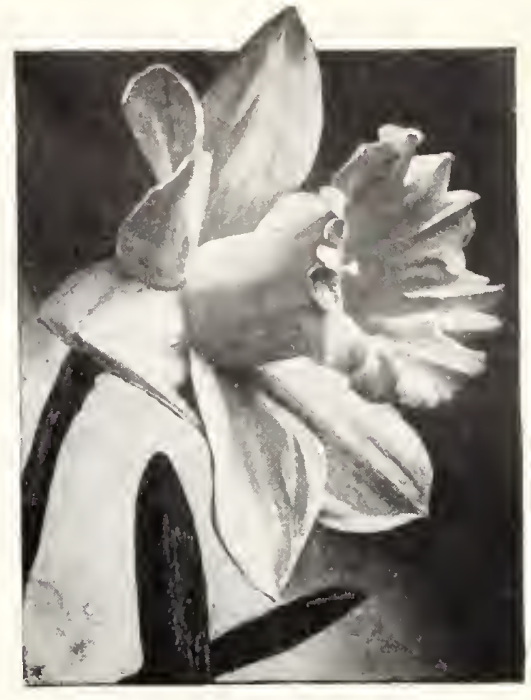

Narcissus, Emperor
AMARYLLIS

\section{GIANT AMERICAN HYBRIDS}

One of the finest strains in cultivation; flowers are of enormous size and beautifully striped and flaked. Florists will find this a very profitable pot plant for store sales as they can be flowered in a short time and will sell readily when in bloom at a good price. 50 c. each; doz., $\$ 5.25 ; \$ 40.00$ per 100 .

\section{ANEMONE}

These make delightful flowering plants for pot culture and will sell readily with any florist who has a store trade; also excellent for cutting. They require little attention and grow easily in a cool greenhouse.

DeCaen. Single French, mixed, 40c. per doz.; per 100, $\$ 2.75$; $\$ 22.00$ per 1000 .

His Excellency. Large flowering Poppy Anemone; deep scarlet. 55 c. per doz.; per $100, \$ 3.50 ; \$ 30.00$ per 1000 .

St. Brigid. Semi-double; various colors. 65c. per doz.; per 100 , $\$ 3.75 ; \$ 32.50$ per 1000 .

\section{IRIS FILIFOLIA}

A strain of Spanish Iris flowering 2 or 3 weeks earlier. Imperator. Deep blue; one of the best for

Wedgewood. Light blut $\$ 0.60 \quad \$ 3.75 \quad \$ 32.50$

\section{NARCISSUS, POETAZ}

Laurens Koster. Pure white with orange cup; especially recommended for pans; excellent cut flower variety. Monster bulbs, $85 \mathrm{c}$. per doz.; per $100, \$ 5.75 ; \$ 50.00$ per 1000 .
NARCISSUS
Bicolor Victoria. Perianth creamy white, trumpet yellow. First size bulbs, $\$ 1.10$ per doz.; per $100, \$ 7.50 ; \$ 67.50$ per 1000 . Monster bulbs, $\$ 1.30$ per doz.; per $100, \$ 9.50 ; \$ 87.50$ per 1000 .

Emperor. Pure yellow trumpet, primrose perianth. First size bulbs, $\$ 1.10$ per doz.; per $100, \$ 7.50 ; \$ 67.50$ per 1000 . Monster bulbs, $\$ 1.30$ per doz.; per $100, \$ 9.50 ; \$ 87.50$ per 1000 .

King Alfred. Perianth and trumpet golden yellow. First size bulbs, $\$ 1.35$ per doz.; per $100, \$ 10.25 ; \$ 95.00$ per 1000 . Monster bulbs, $\$ 2.00$ per doz.; per $100, \$ 13.75 ; \$ 130.00$ per 1000 .

Sir Watkin. Medium trumpet; sulphur yellow, cup tinged with orange. $\$ 1.15$ per doz.; per $100, \$ 8.25 ; \$ 75.00$ per 1000 .

\begin{tabular}{|c|c|c|c|c|c|c|}
\hline \multicolumn{7}{|c|}{ NARCISSUS } \\
\hline \multirow[t]{3}{*}{ MICHELL'S } & B I G & BL & $\mathbf{O M}$ & PAPER & \multicolumn{2}{|c|}{ WHI TE } \\
\hline & & & & & 5,000 & 10,000 \\
\hline & & & & & $\begin{array}{l}\text { lots, per } \\
1000\end{array}$ & $\begin{array}{c}\text { lots, per } \\
1000\end{array}$ \\
\hline & & $\$ 0.4$ & $\$ 3$. & $\$ 25$. & $\$ 24$ & $\$ 23.50$ \\
\hline & & .5 & 3. & 28.50 & 27 & 27.00 \\
\hline & & .65 & & 32.00 & 31.00 & 30.50 \\
\hline & & .75 & 4.25 & 36.00 & 35.00 & 34.50 \\
\hline
\end{tabular}

\section{RANUNCULUS Buttercup}

This has become very popular as a florists cut flower; easily grown in a cool greenhouse for winter blooming or in cold frames for spring.

Palaflor Strain $(N e w)$. Flowers extra large and full. A beautiful range of colors, such as subtle shades and pastel colorings of pinks and yellows, as well as other new shades. $\$ 1.50$ per doz.; per $100, \$ 10.50 ; \$ 100.00$ per 1000 .

Giant Fringed Mixed. Extra large bulbs $45 \mathrm{c}$ per doz.; per 100, $\$ 2.53 ; \$ 20.00$ per 1000 .

\section{MICHELL'S BULBS FOR ROCK GARDENS}

The demand for rock gardens has become so great, there is no doubt but that a great many florists and landscape gardeners have a considerable number of inquiries for the proper arrangement of the garden and calls for planting material for same. We have compiled a carefully selected list of bulbs best suited for such purposes and which can be successfully grown in conjunction with perennials. The proper arranging and planting of such a garden will certainly increase your trade.

\section{Lilies.}

Elegans Mixed.

Elegans, Leonard Joerg.

Krameri.

Rubellum.

Tenuifolium.

Umbellatum.

Narcissus.
Bulbocodium Conspicuus.
Cervantes.
Thalia.
William Goldring.
W. P. Milner.
Jonquils.

Tulips. Botanical or Species. Aconite, Winter.

Brodiaeas.

Calochortus (Bullerfly Tulip).

Chionodoxa.

Colchicum (Autumn Flouering Crocus).
Crocus.

Erythronium (Dog's Tooth V'iolet)

Grape Hyacinths.

Fritillaria Meleagris.

Scillas.

Snowdrops.

Zephyranthes (Fairy Lily).

For description and prices see body of this catalog under their respective headings. 
IMPORTANT NOTICE.-It should be borne in mind that Easter 1932 comes on March 27th, and it is of importance that florists keep this in mind, particularly when planting and handling their bulbous stock.

Our Tulip Bulbs are grown in the best districts of Holland to insure perfect development and full sized stock. Those who place their orders with us may be sure of getting bulbs that will not only bloom, but also prove true to name.

The asterisk $\left(^{*}\right)$ preceding the variety denotes that it is suitable for forcing as well as bedding. The letters $\mathrm{E}, \mathrm{F}, \mathrm{G}$ and $\mathrm{H}$ following the variety indicate their relative time of blooming, the E's being the earliest to bloom. The figures indicate the normal height in inches. Tulip bulbs are packed 250 in a bag; please order in units of this number if possible.

If Tulip bulbs are wanted by Parcel Post, add 10c. per doz., 25c. per 100, for postage.

\section{DARWIN TULIPS}

These are the most profitable Tulip for the florist to grow. The flowers being borne on long stems, make them valuable for cutting. Our prices are based on the best quality and for topsized bulbs.

Afterglow (Catherine Havemeyer). F26.

Rosy orange, salmon tinted edge.

Doz. $\quad 100 \quad 1000$

Aphrodite. F32. Silvery rose pink, with white base; large flowers.....

*Baronne de la Tonnaye. F26. Rose pink, shading paler towards edges of petals

*Bartigon. F24. Fiery red, white base...

Bleu Aimable. F25. Lavender, with white base, starred blue.

*Centenaire. E30. Rich violet rose with large blue center; enormous flowers; excellent for border or for early forcing

*City of Haarlem. F27. One of the best scarlet varieties; steel blue base with white outline.

* Clara Butt. G21. Delicate salmon pink; extra fine forcer; good bedder...........

*Dream. G24. Rosy lilac and mauve...

${ }^{*}$ Farncombe Sanders. F25. Brilliant scarlet; flowers of large size.

Feu Brilliant. F28. Glowing vermilion scarlet; flowers large..............

*Gretchen or Margaret. H22. Soft salmon rose; splendid for cutting...........

*King George V. F25. Salmon scarlet shaded rose, blue base................

La Candeur or White Queen. F24. White, tinted blush when opening.......

* La Fiancee. G30. Deep rose shading to old rose, delicate pink at edges.........

La Tulipe Noire. G25. Deep maroon black, with a velvety sheen...........

*Le Notre. E24. Beautiful pink ........ silvery margin; fine forcer.

Mrs. Potter Palmer. G26. Rich purple. .

Orange Perfection. G26. Salmon orange, shading to scarlet as it ages............

*Phillippe de Commines. E24. Deep purple; flowers large...............

*Pride of Haarlem. F26. Rosy carmine.

*Prince of the Netherlands. F31. Cerisescarlet edged rose, blue base...........

*Princess Elizabeth. F23. Clear pink, changing with age to a deeper shade.....

*Professor Rauwenhoff. F26. Cherry red, blue star at base; large flowers. . . . . . . . . .

${ }^{*}$ Rev. H. Ewbank. F20. Light heliotrope edged lavender; very fine.............

*Roi d'Islande (Matchless). F27. A rare shade of old rose; very effective.........

Venus. F30. Silvery rose, white base with pale blue ring

${ }^{*}$ W. Copeland. E24. Delicate lavender.

*William Pitt. E24. Deep crimson.....

Darwin Mixed. All colors. .
$\$ 0.60 \quad \$ 3.75 \quad \$ 32.50$

$.90 \quad 6.25 \quad 57.50$

$\begin{array}{lll}.45 & 3.00 & 25.00\end{array}$

$\begin{array}{lll}.50 & 3.50 & 28.50\end{array}$

$60 \quad 3.75 \quad 32.50$

$.50 \quad 3.25$

27.50

$.65 \quad 4.25$

37.50

$.45 \quad 3.00$

24.00

$\begin{array}{lll}60 & 3.75 & 32.50\end{array}$

$.45 \quad 3.00$

25.00

.65

4.00

35.00

$.45 \quad 3.00 \quad 25.00$

$\begin{array}{lll}85 & 6.00 \quad 55.00\end{array}$

$\begin{array}{lll}60 & 3.75 & 32.50\end{array}$

$\begin{array}{lll}.70 & 4.50 \quad 40.00\end{array}$

$.60 \quad 3.75$

32.50

$\begin{array}{lll}.50 & 3.50 & 28.50\end{array}$

$45 \quad 3.00 \quad 25.00$

$\begin{array}{lll}.65 & 4.25 & 37.50\end{array}$

$2.00 \quad 14.00 \quad 135.00$

$\begin{array}{lll}60 & 3.75 & 32.50\end{array}$

$\begin{array}{lll}.45 & 3.00 & 25.00\end{array}$

$\begin{array}{lll}.50 & 3.50 \quad 30.00\end{array}$

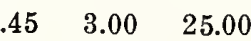

$\begin{array}{lll}50 & 3.25 & 27.50\end{array}$

$\begin{array}{lll}.50 & 3.25 & 27.50\end{array}$

$\begin{array}{lll}60 & 3.75 & 32.50\end{array}$

$.85 \quad 6.00$

$.50 \quad 3.50$

$.50 \quad 3.50$

$.45 \quad 2.75$
28.50

30.00

22.50

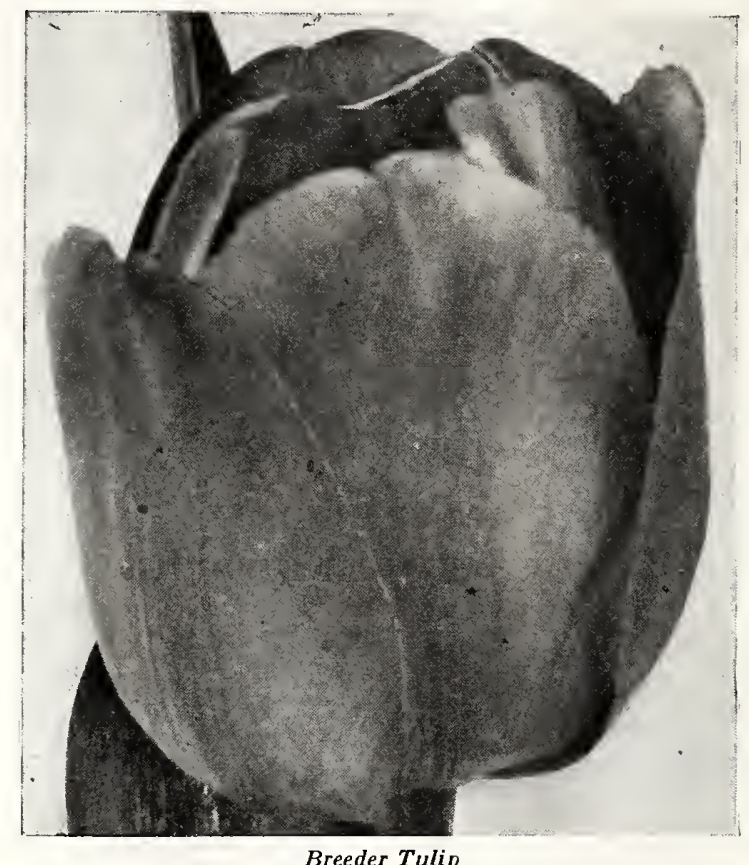

\section{DUTCH BREEDER TULIPS}

A May-flowering type, similar to the Darwins, in their tall, strong growth, but an entirely different range of colors, running mostly in shades of bronze, terra cotta and buff.

Apricot. G26. Bronzy buff, shaded apricot, base olive green..............\$0.65

Aspasia. G24. Wine red, shaded purple... .65

Bacchus. F28. Dark violet blue, base

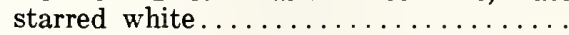

*Bronze Queen. G28. Soft buff, inside tinged golden bronze................. flushed rosy brown...............

*Dom Pedro. G24. Coffee brown, shaded

maroon, inside mahogany ................

Jaune d'Oeuf. H23. Apricot, inside bronzy yellow....................... Louis XIV. G28. Dark purple, broad marLucifer. G24. Large, reddish-orange. MacMahon (Turenne). F24. Purplish

brown, margined soft yellow ..........
Madame Lethierry. F26. Deep rose pink

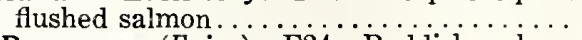

*Panorama (Fairy). F24. Reddish mahogany, with bronze shading. . . . . . . . .

*Pink Pearl. Lilac pink, inside rose..... .

*Prince of Orange. G24. Terra cotta brown shaded yellow ...................

St. James. G28. Chestnut brown flushed

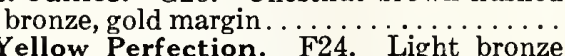

*Yellow Perfection. F24. Light bronze yellow, edged and shaded golden yellow. .

Breeder Tulips. Mixed................
Doz. 100

1000

$\$ 4.00 \quad \$ 35.00$

$4.00 \quad 35.00$

$80 \quad 4.75$

42.00

$.50 \quad 3.25$

28.00

$.60 \quad 3.75$

32.50

$.70 \quad 4.25$

$\begin{array}{ll}.75 & 4.50\end{array}$

37.50

$.60 \quad 3.75$

40.00

$.50 \quad 3.25$

32.50

$.85 \quad 6.00$

27.50

$60 \quad 3.75$

55.00

$.75 \quad 5.00$

32.50

.60

1.00

3.75

7.00

45.00

$.60 \quad 3.75$

32.50

65.00

$.60 \quad 3.75$

32.50

.65

4.00

32.50

$.45 \quad 3.00$

35.00

25.00

Write for special prices on larger quantities of Tulip Bulbs 


\section{MICHELL'S DARWIN TULIPS}

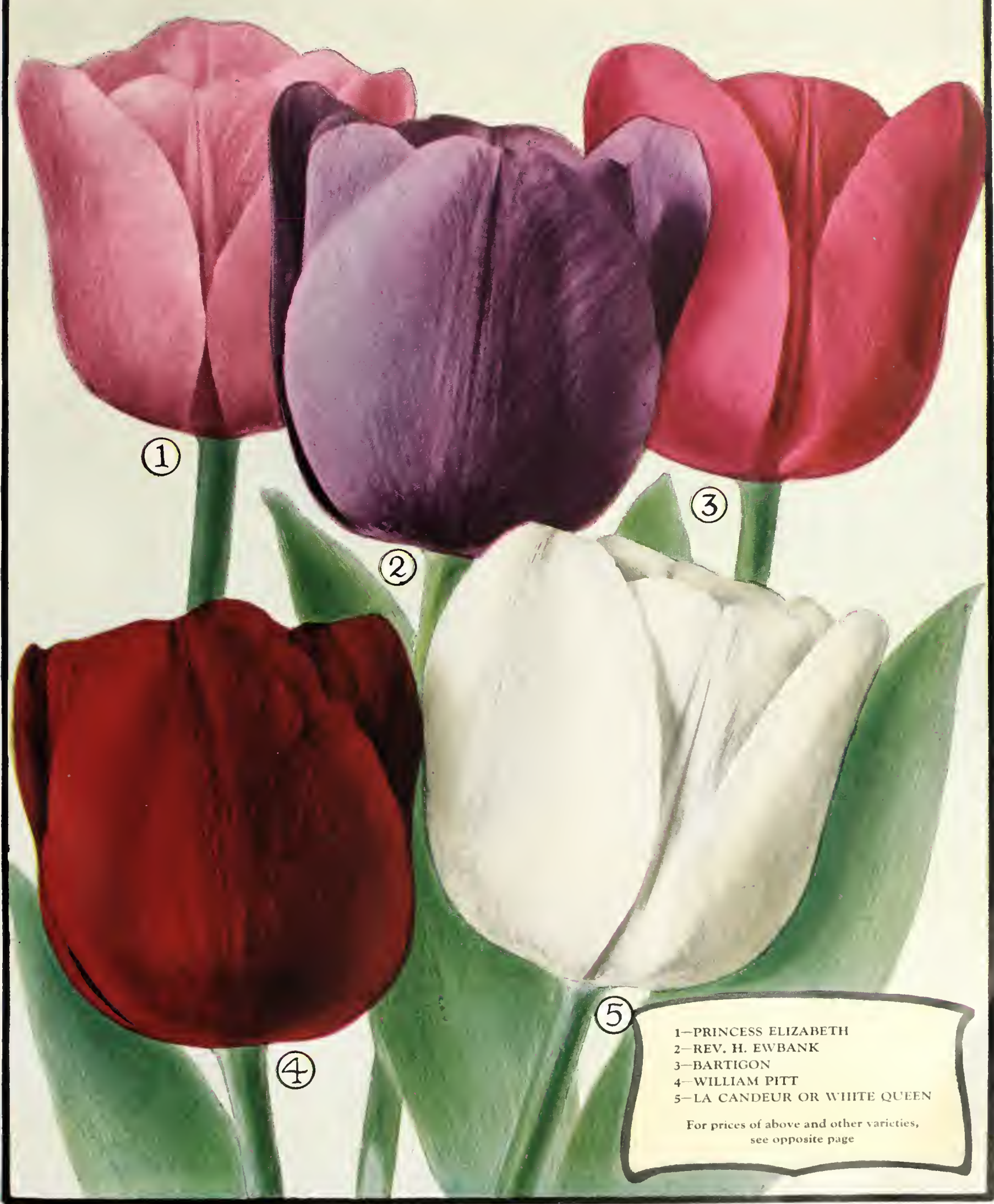


If Tulip Bulbs are wanted by Parcel Post, add 10c. per doz., 25c. per 100, for postage.

\section{MAY FLOWERING OR COTTAGE TULIPS}

Desirable for outdoor planting for a supply of brilliant cut blooms in May; some varieties also being valuable for forcing. All single flowering except where noted.

The asterisk preceding the variety denotes that it is suitable for forcing as well as bedding. The letters $\mathrm{E}, \mathrm{F}, \mathrm{G}$ and $\mathrm{H}$ following the variety indicate their relative time of blooming, the E's being the earliest to bloom. The figures indicate the normal height in inches.

Ambrosia (New Hybrid). F25. Outside color, lilac rose, edged apricot, inside color,

bright orange changing to tan........... \$1.0

Argo. F22. Golden yellow mottled red,

passing to reddish brown .................. .75

Blue Flag (Double). G19. Violet blue...
Dido. G30. Large, well formed flowers

deep, rich pink, shaded salmon yellow with soft orange suffusion at edges of petals; very fragrant..................... * Fairy Queen. G20. Rosy heliotrope, * Gesneriana Lutea. H24. Golden yellow. Gesneriana Spathulata. G24. Rich scarlet, blue-black center.

Grenadier. F24. Brilliant orange red....

* Inglescombe Pink. F24. Salmon pink...

*Inglescombe Yellow. F20. Bright yellow; often called Yellow Darwin.

John Ruskin. G18. Apricot rose, edged pale yellow.

Lord Carnarvon. F24. White, with large violet rose margin, intensifying to wine red; this variety belongs to the Triumph class.

Doz. $100 \quad 1000$

$1.00 \$ 7.00 \quad \$ 65.00$

$\begin{array}{rrr}.75 & 5.00 & 45.00 \\ 1.10 & 8.00 & 75.00\end{array}$

$\begin{array}{lll}.90 & 6.50 \quad 60.00\end{array}$

$45 \quad 3.00 \quad 25.00$

$\begin{array}{lll}.50 & 3.25 & 28.00\end{array}$

$\begin{array}{lll}50 & 3.50 & 30.00\end{array}$

$\begin{array}{lll}.60 & 3.75 & 32.50\end{array}$

$.45 \quad 2.75 \quad 22.50$

$\begin{array}{lll}.50 & 3.25 \quad 28.00\end{array}$

* Moonlight. H24. Canary yellow......

* Mrs. Moon. H24. Large golden yellow.

Orange King. G24. Glistening deep orange, shaded rose, yellow center. White

*Picotee (Maiden's Blush). G20. White with distinct pink edged border......... shading to lighter at edge; inside petals shell pink with ivory base............

Sarah Bernhardt (Hobbema or Le Reve). E12. Soft rose, shaded apricot........

*The Fawn. G20. Pale rose fawn, changing to blush rose; flowers egg-shaped. .... margined pale pink, with white base; a lily-flowering type.

May Flowering Tulips (Single). Mixed.

$\begin{array}{lll}.65 & 4.00 \quad 35.00\end{array}$

$\begin{array}{lll}.45 & 3.00 & 25.00\end{array}$

$\begin{array}{lll}.50 & 3.25 & 28.00\end{array}$

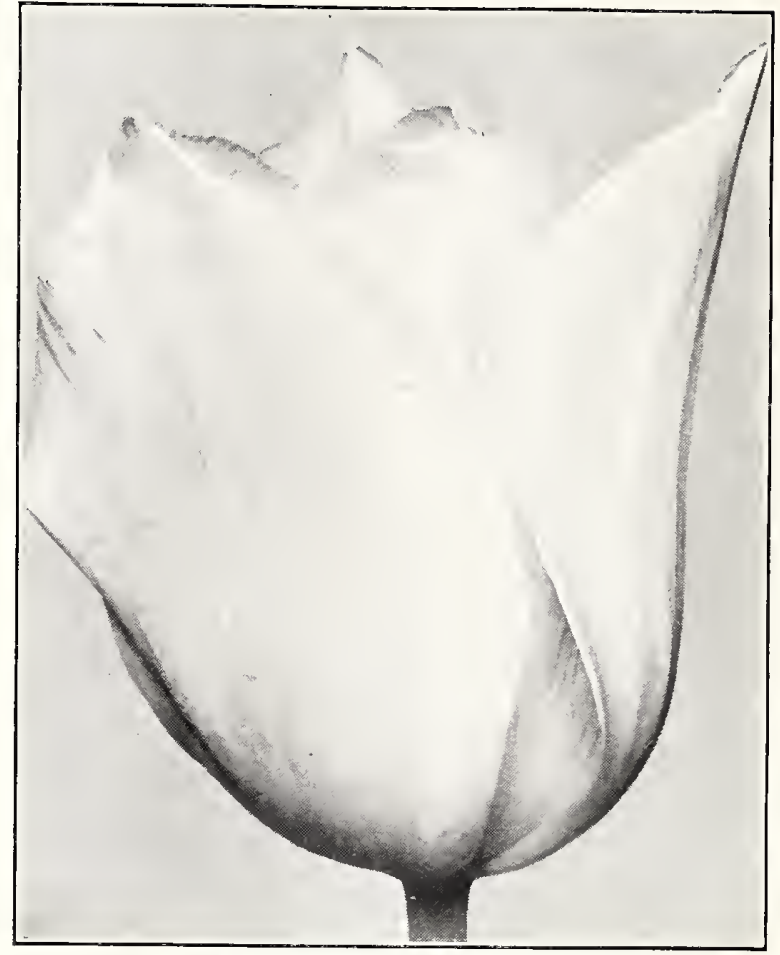

May Flowering or Coltage Tulip

\section{DOUBLE EARLY TULIPS}

The Double Tulips usually flower a few days later than the Single Early varieties. They are very popular both for bedding and forcing. 'The asterisk $\left({ }^{*}\right)$ preceding the variety denotes that it is suitable for forcing as well as bedding. The letters $\mathrm{A}, \mathrm{B}$ and $\mathrm{C}$ following the variety indicate their relative earliness to bloom, the A's being the earliest, followed by the B's and later by the C's. The figures indicate the normal height in inches.

*Azalea. B12. Beautiful deep rose, flush-

Doz. $100 \quad 1000$

ed salmon; excellent for forcing....... $\$ 0.60$

*Boule de Neige. B10. Pure white..... . .60

Couronne d'Or (Crown of Gold). B12. Rich golden yellow, flushed orange.......... 6

Electra. B12. Rosy violet red........ $\quad .75$

*Imperator Rubrorum. B10. Brilliant scarlet; extra fine................. $\quad .75$

*Lucretia. B14. Rose feathered violet. . $\quad .50$

*Mr. Van der Hoef (Yellow Murillo). A10. Rich golden yellow.

*Murillo. B10. Delicate rose pink..... $\quad .50$

*Peach Blossom. B12. Bright rose pink, flushed white, deepening to carmine rose with age...................... 60

Rubra Maxima. B10. Dazzling scarlet. . .60

*Salvator Rosa. B10. Deep rose pink... .65

*Tea Rose. B12. Sulphur yellow, shading to orange..............................

Toreador. A10. Reddish orange, with yellow border.................... .75

*Tournesol, Red and Yellow. B8..... .75

*Vuurbaak. B12. Brilliant orange scarlet .65
$\$ 3.75 \$ 32.00$

$3.75 \quad 32.00$

$4.00 \quad 35.00$

$5.00 \quad 45.00$

$4.50 \quad 40.00$

$4.00 \quad 34.00$

$3.25 \quad 28.00$

3.75

32.50

$3.75 \quad 32.00$

$4.00 \quad 35.00$

$3.50 \quad 30.00$

$5.00 \quad 45.00$

$4.75 \quad 42.50$

$4.00 \quad 35.00$
$3.25 \quad 28.00$

\section{DOUBLE MIXED TULIPS}




\section{MICHELL'S SUPERB TULIP BULBS}

The asterisk $\left(^{*}\right)$ preceding the variety denotes that it is suitable for forcing as well as bedding. The letters A, B and C following the variety indicate their relative earliness to bloom, the A's being the earliest, followed by the B's and later by the C's. The figures indicate the normal height in inches. Tulip bulbs are packed 250 in a bag; please order in units of this number if possible.

If Tulip bulbs are wanted by Parcel Post add 10c. per doz., 25c. per 100, for postage.

\section{SINGLE EARLY TULIPS}

Doz. 100

*Albion (White Hawk). A12. Pure white; excellent forcer and bedder...........\$0.60 $\$ 3.75 \$ \$ 32.50$

*Belle Alliance. B8. Rich scarlet; one of the finest forcing and bedding varieties.

*Brilliant Star. A12. Vermilion scarlet. .

*Chrysolora. B10. The finest golden yellow for bedding; also fine for forcing

* Couleur de Cardinal. C10. Bright scarlet; for forcing or bedding.

*Cramoise Brilliant. C10. Glowing scarlet, with yellow base..

*De Wet (Fireglow). B15. Beautiful golden yellow flushed and stippled fiery orange scarlet................................... lighter, white stripe in center of petals . . .

*Fred Moore. B12. Bright orange, sweet scented; fine for forcing.............

${ }^{*}$ Ibis. B12. Bright carmine pink, very large flowers ..................... border; for forcing or bedding..........

*Lady Boreel (Joost Van Vondel White). B12. Pure white and of splendid form........

* La Reine. B12. White, flushed faintly with pink; an early forcer............

${ }^{*}$ Mon Tresor. A10. Golden yellow......

*Pink Beauty. B12. Bright cherry rose, center of petals striped white.........

*Primrose Queen (Herman Schlegel). B10. Pale yellow; fine form..............

*Prince of Austria. B12. Orange scarlet shading to brick red................

*Proserpine. A12. Rosy carmine, white center; large, sweet scented flowers......

*Prosperity. B9. Delicate rosy pink....

*Rising Sun. B15. Rich golden yellow; one of the largest tulips in existence.....

*Rose Luisante. C10. Deep rose pink; flowers large..................

*Vermilion Brilliant. B10. Brilliant vermilion scarlet; early forcer............

Wouverman. B9. Rich claret purple.....

*Yellow Prince. B10. Golden yellow; excellent for early forcing or bedding......

$65 \quad 4.00$

$\begin{array}{lll}.50 & 3.25 & 27.50\end{array}$

$.65 \quad 4.25 \quad 37.50$

$.65 \quad 4.00$

34.00

$.50 \quad 3.25$

27.50

$.80 \quad 5.50$

50.00

$\begin{array}{lll}.50 & 3.50 \quad 30.00\end{array}$

$\begin{array}{lll}50 & 3.50 \quad 30.00\end{array}$

$.50 \quad 3.25 \quad 28.00$

$\begin{array}{lll}.75 & 4.75 & 42.50\end{array}$

$\begin{array}{lll}.75 & 4.50 \quad 40.00\end{array}$

$\begin{array}{lll}45 & 3.00 & 25.00\end{array}$

$\begin{array}{lll}.75 & 4.75 & 42.50\end{array}$

$\begin{array}{lll}.85 & 6.00 \quad 55.00\end{array}$

$\begin{array}{lll}.60 & 3.75 & 32.50\end{array}$

$\begin{array}{lll}.50 & 3.50 \quad 30.00\end{array}$

$\begin{array}{lll}.75 & 4.75 & 42.50\end{array}$

$\begin{array}{lll}.50 & 3.25 & 28.50\end{array}$

$\begin{array}{lll}.65 & 4.00 \quad 35.00\end{array}$

$\begin{array}{lll}.65 & 4.00 \quad 35.00\end{array}$

$\begin{array}{lll}.60 & 3.75 & 32.00\end{array}$

$\begin{array}{lll}.75 & 5.00 \quad 45.00\end{array}$

$\begin{array}{lll}.65 & 4.00 \quad 35.00\end{array}$

\section{SINGLE TULIPS IN MIXTURE}

Our mixtures are made up from large flowering varieties with a wide range of bright colors and will give excellent satisfaction.

$\begin{array}{rrrr}\text { Early Varieties, Superfine Quality...... } \$ 0.45 & \$ 3.00 & \$ 25.00\end{array}$

\section{REMBRANDT TULIPS}

These belong to the Darwin Class; flowers striped, blotched and marked with different shades and colors; they flower about the same time as the Darwins. Height, 18 to 22 inches.

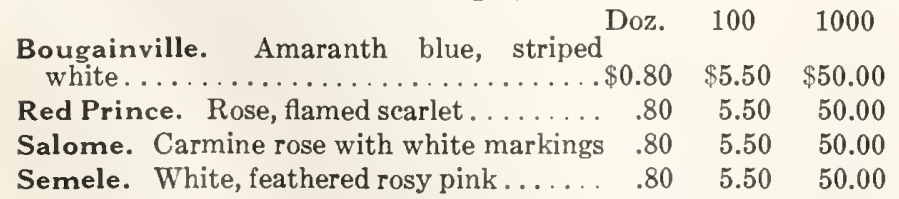

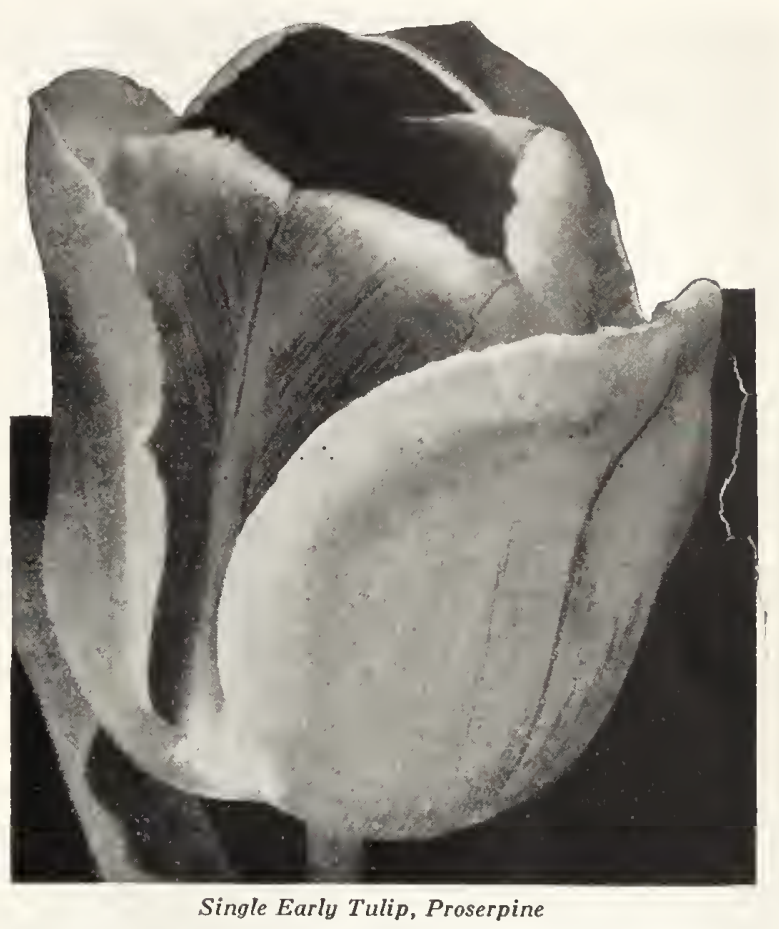

BUNCH FLOWERED TULIPS (New)

Monsieur Mottet. Ivory white; produces Doz. $100 \quad 1000$. 4 to 6 blooms on a stem; an excellent cut flower variety; height, 24 inches . . . . . . \$0.75 $\$ 5.00 \quad \$ 45.00$

\section{BOTANICAL OR SPECIES TULIPS}

*8 Clusiana (Lady Tulip). Outer petals cherry red, inner petals creamy white, with violet base ................... $\$ 0.7$ Doz. $\quad 100 \quad 1000$

11 Eichleri. Immense crimson-scarlet, shad$\begin{array}{llll}\text { ed orange; black center marked with gold } & .90 & 6.50 & 60.00\end{array}$

10 Greigi. Large, brilliant orange-scarlet flowers, with yellow and black center ... $1.35 \quad 9.50 \quad 90.00$

6 Kauf manniana. Creamy white, tinged carmine; one of the earliest..........

14 Marjoletti. Soft primrose shaded carmine red at base; early bloomer.

15 Sylvestris (Florentina Odorato). Rich yellow, fragrant flowers

$\begin{array}{lll}.90 & 6.50 \quad 60.00\end{array}$

$\begin{array}{lll}.75 & 5.00 \quad 45.00\end{array}$

$\begin{array}{lll}70 & 4.50 \quad 40.00\end{array}$

\section{PARROT OR DRAGON TULIPS (Late)}

These belong to the late flowering class and on account of their peculiar markings and shadings are much in demand. The petals have feathered edges and in addition to other colors combine shades of green.

Constantinople. Dark red shaded and tipped with orange.

Fantasy. Beautiful, true salmon-rose, with ragged edges and fantastically shaped petals, outside of which are marked apple green; erect, long stems; grows about 21 inches high

Doz. 100

1000

Lutea Major. Bright yellow with crimson and green stripright

Markgraaf of Baden. Large yeliow, striped scarlet and green

$\$ 0.65 \$ 4.00 \$ 35.00$

Mixed. All colors

$2.00 \quad 15.00 \quad 145.00$

$\begin{array}{lll}65 & 4.00 & 35.00\end{array}$

$65 \quad 4.00 \quad 35.00$

$\begin{array}{lll}60 & 3.75 & 32.00\end{array}$

Write for special prices on larger quantities of Tulip Bulbs 
SPECIAL NOTICE.-We have exercised unusual precaution to see that our growers send us full size bulbs as listed in centimeters; some offerings are being made at low prices under the headi 1 gs of First, Second and Third Size, without reference to the measurements.

PLEASE NOTE.-Original packages of Hyacinth Bulbs contain the following quantities: First size, 50 bulbs; second size, third size, and unnamed, 100 bulbs; miniature, 250 bulbs; if possible please order in these unit quantities.

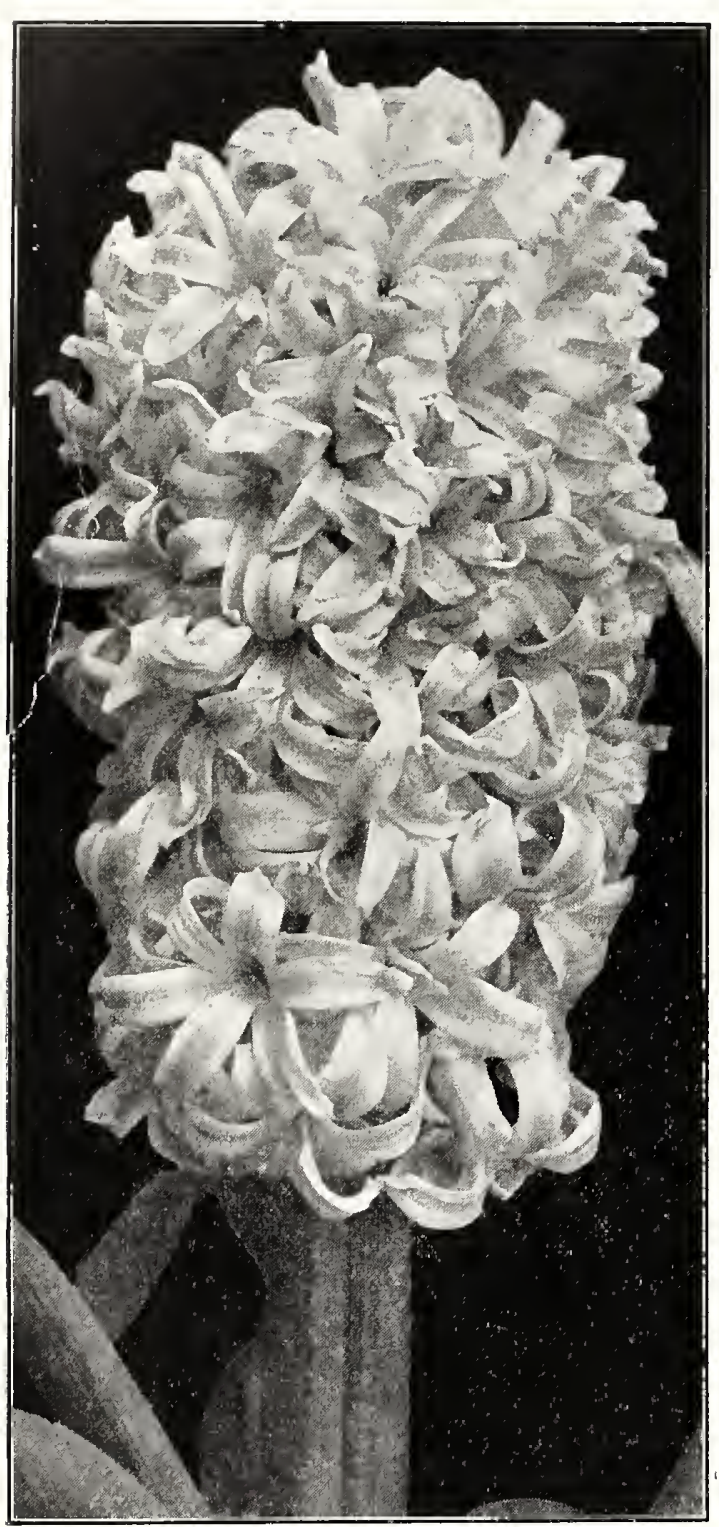

Single Hyacinth

\section{EXHIBITION SIZE \\ (19 СТM. up)}

We offer the largest or top root bulbs that will produce extra large, well filled spikes; we offer them in single varieties only. If wanted by Parcel Post, add 20c. per doz. for postage. Gertrude. A. Deep rose... Grand Maitre. B. Bright porcelain blue. King of Blues. D. Deep blue.

King of Yellows. C. Orange yellow. Lady Derby. A. Delicate pink. La Grandesse. C. Pure white

La Victoire. A. Beautiful bright scarlet.

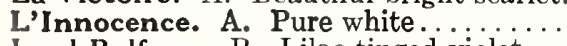
Lord Balfour. B. Lilac tinged violet... Marconi. B. Rich rose pink... Perle Brilliante. B. Pale blue. Queen of Pinks. C. Rose pink. Queen of the Blues. D. Silvery blue Roi des Belges. A. Deep red. Yellow Hammer. A. Pure yellow or pans.
Doz. $\quad 100 \quad 1000$ $\$ 1.00 \quad \$ 6.50 \quad \$ 60.00$

As there is a slight variation as to the time of blooming of the various sorts, we have indicated their relative time of flowering by letters following the variety, the A's being the earliest, the D's the latest.

\section{SINGLE FIRST SIZE (18-19 ctm.}

These are especially desirable for growing in pots or glasses, or for high grade bedding, bearing large well developed spikes.

If wanted by Parcel Post, add 20c. per doz. for postage.

City of Haarlem. C. Golden yellow

Gertrude. A. Deep rose..

Gigantea. C. Flesh pink.

Grand Maitre. B. Bright porcelain blue

King of Blues. D. Deep blue.

King of Yellows. C. Orange yellow ....

Lady Derby. A. Delicate pink.

La Grandesse. C. Pure white...

La Victoire. A. Beautiful bright scarlet. . .

L'Innocence. A. Pure white.

Doz. $\quad 100 \quad 1000$

Lord Balfour. B. Lilac tinged violet.

Marconi. B. Rich rose pink...

Perle Brilliante. B. Pale blue.

Queen of the Blues. D. Silvery blue

Queen of the Pinks. C. Rose pink.

Roi des Belges. A. Deep red.

Yellow Hammer. A. Pure yellow . .

\section{SINGLE SECOND SIZE (17-18 $\mathrm{ctm}$.}

For bedding, these are ideal and are also well adapted for forcing in pats

If wanted by Parcel Post, add 15c. per doz.; 50c. per 100, for postage.

City of Haarlem. C. Golden yellow..............

Gertrude. A. Deep rose.

Gigantea. C. Flesh pink...

Grand Maitre. B. Bright porcelain blue.

King of Blues. D. Deep blue.

King of Yellows. C. Orange yellow

Lady Derby. A. Delicate pink. ...

La Grandesse. C. Pure white.

La Victoire. A. Beautiful bright scarlet

Doz. $\quad 100 \quad 1000$

L'Innocence. A. Pure white.

Lord Balfour. B. Lilac tinged violet.

Marconi. B. Rich rose pink...

Perle Brilliante. B. Pale blue

Queen of the Blues. D. Silvery blue

Queen of the Pinks. C. Rose pink.

Roi des Belges. A. Deep red.

Yellow Hammer. A. Pure yellow

\section{SINGLE THIRD SIZE}

EXTRA LARGE BULBS (16-17 ctm.)

Just the grade of bulbs for the florist whose trade demands moderately priced hyacinths. These are excellent for either forcing or bedding.

If wanted by Parcel Post, add 15c. per doz.; 50c. per 100, for postage. City of Haarlem. C. Golden yellow...

Gertrude. A. Deep rose.

Gigantea. C. Flesh pink.

Grand Maitre. B. Bright porcelain blue

King of the Blues. D. Deep blue.

Lady Derby. A. Delicate pink.

La Grandesse. C. Pure white.

La Victoire. A. Beautiful bright scarlet

L'Innocence. A. Pure white.

Lord Balfour. B. Lilac tinged violet.

Perle Brilliante. B. Pale blue.

Queen of Pinks. C. Rose pink.

Queen of the Blues. D. Silvery blue. .

Roi des Belges. A. Deep red..........

Doz. $\quad 100 \quad 1000$

$\begin{array}{lll}\$ 0.70 & \$ 4.75 & \$ 42.50\end{array}$

\section{HYACINTH GLASSES}

A few Hyacinths started in these glasses will increase your sales wonderfully. We offer them in assorted colors.

Belgian Style. Tall... Each Doz.

$\ldots \ldots \ldots \ldots \ldots \ldots+30 \quad \$ 3.25$

Write for Special Prices on Larger Quantities of Hyacinths 


\section{MICHELL'S HYACINTHS}

PLEASE NOTE.--Original packages of Hyacinth Bulbs contain the following quantities: First size, 50 bulbs; second size third size, and unnamed, 100 bulbs; miniature, 250 bulbs; if possible please order in these unit quantities.

\section{DOUBLE FIRST SIZE 18-19 СТМ.}

While these do not as a rule produce as fine spikes as the single varieties, they are however very satisfactory for bedding or pot culture.

If wanted by Parcel Post, add 20c. per doz. for postage. Blocksberg. Light blue.

Bouquet Tendre. Dark carmine

Delicata. Pale blue............ Doz. $100 \quad 1000$

Garrick. Blue, dark center......... $\quad \begin{array}{lll}\$ 0.90 & \$ 6.00 & \$ 55.00\end{array}$

Lord Wellington. Rich pink.

Prince of Waterloo. Pure white

Sunflower. Pure yellow........

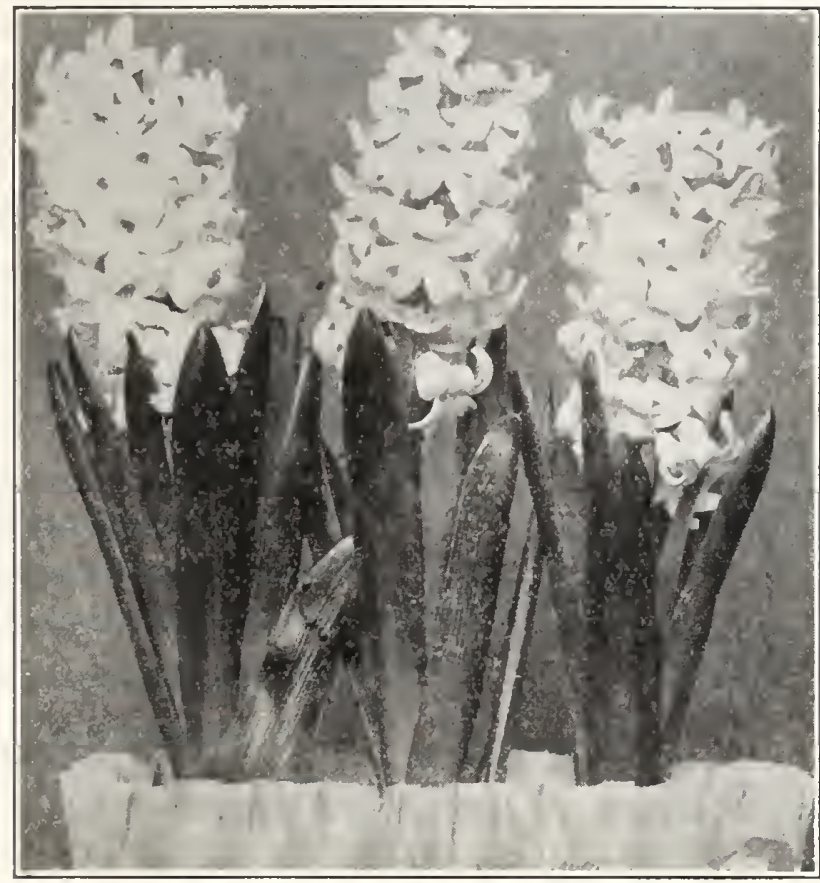

. Tiniature or Dutch Roman Iyacinths

\section{MINIATURE OR DUTCH ROMAN H Y A CINTHS (14-15 ctm.)}

Excellent for growing in pots, pans or boxes. Valuable for designs and center pieces.

If wanted by Parcel Post, add 15c. per doz.; 50c. per 100 , for postage.

Gertrude. Deep pink

Grand Maitre. Bright porcelain blue

King of the Blues. Deep blue.

Lady Derby. Delicate pink.

La Grandesse. Pure white.

La Victoire. Beautiful bright scarlet.... Doz. $100 \quad 1000$

L'Innocence. Pure white............ $\$ 0.60 \quad \$ 3.75 \quad \$ 32.50$

Lord Balfour. Lilac, tinged violet

Queen of the Blues. Silvery blue.

Queen of the Pinks. Rose pink.

Roi des Belges. Deep red

Yellow Hammer. Pure yellow.

\section{SPECIAL NOTE}

We call the attention of our customers to the fact that bulbs of Miniature or Dutch Roman Hyacinths we offer are $14-$ to $15-\mathrm{ctm}$. Therefore, please do not compare our prices with those that may be offered in smaller sizes and at lower prices.

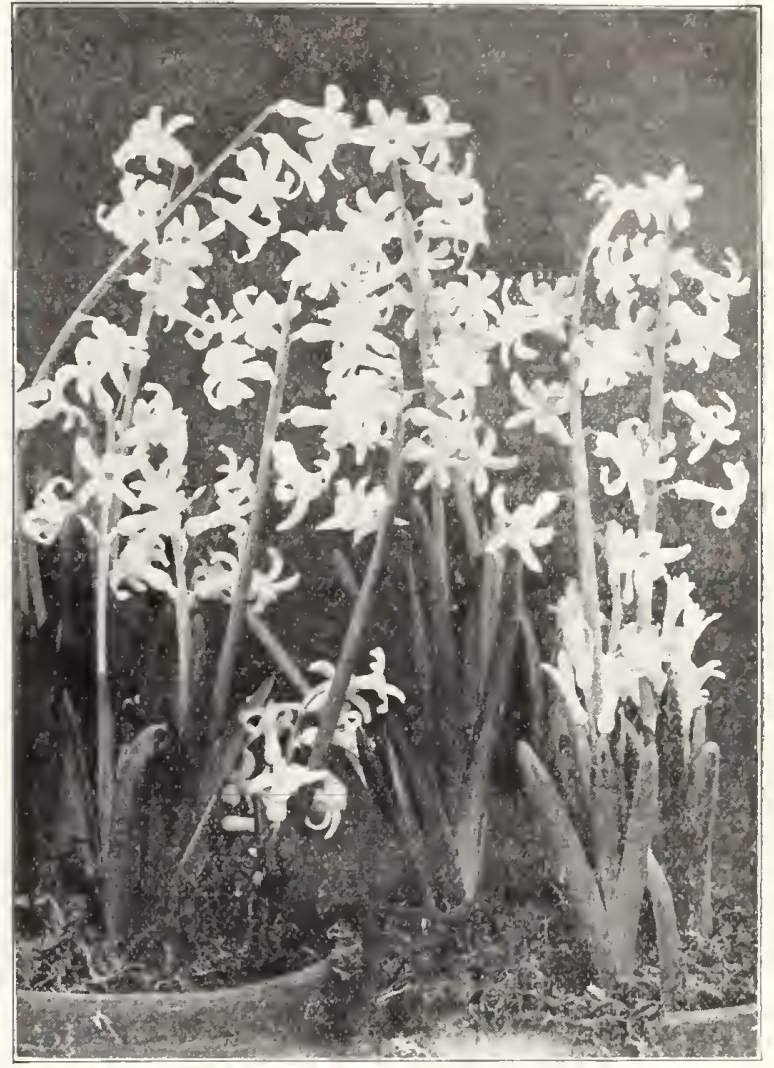

Michell's II hite Roman IIyacinths

\section{FRENCH RONAN HYACINTHS}

These are very useful for those who grow for their own cut flower work; excellent for design work.

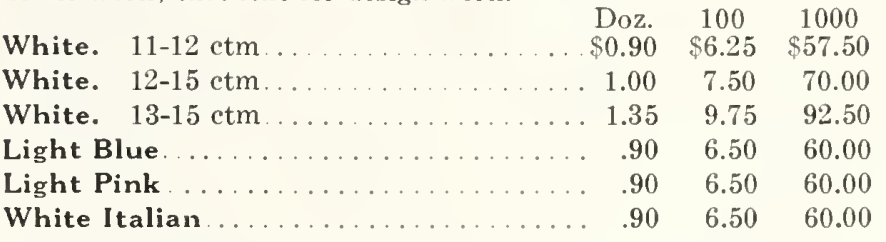

Write for special prices on larger quantities of Hyacinths.

\section{DON'T LET YOUR BULBS FREEZE}

Every year near Easter time, when the florist is looking forward to a banner lot of Hyacinths, Tulips and Narcissus, for sale at that season, there are some who suffer losses they could easily avoid by a little forethought. When potting bulbs give them a thorough watering and place in a frameif you have one-on a bed of cinders or ashes, this will allow the excess moisture to drain away. When the bulbs are potted and placed they should be covered with screened ashes or sand to a depth of at least three inches above the top of pots. When permanent cold weather sets in, cover with long straw manure (do not use leaves). During severe winter and on cold nights, keep sash on the frames, you cannot expect the best results from bulbs if they are allowed to freeze excessively, it ruins the flower germ.

It is, of course, understood, that this suggestion applies to northerly latitudes. In all cases bulbs should be unpacked and stored or planted upon arrival. 


\section{AMERICAN GROWN}

In offering these bulbs, we are pleased to advise our customers that we have contracted with the best growers in this country for our stock, especial care having been given to quality and grading and we are confident that the stock we offer will be of the very best procurable. We advise early ordering, to assure delivery of varieties and quantities desired. The letters, following the varieties, indicate their relative time of flowering, the A's being the earliest to bloom, the D's the latest.

If Narcissus bulbs are wanted by Parcel Post, add 15c. per doz., 40c. per 100, for postage.

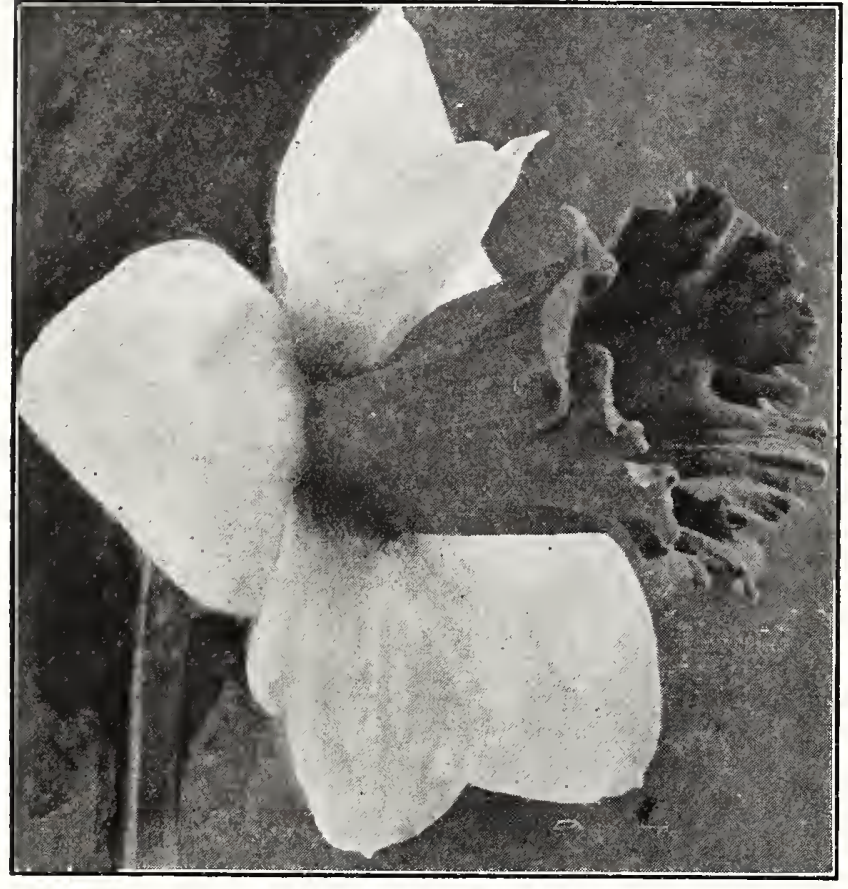

Narcissus, Glory of Sassenheim

\section{SINGLE NARCISSUS GIANT TRUMPET VARIETIES}

Admiral Tromp. D. White perianth, yel- Doz. 100 low trumpet; flowers large ........... \$2.75 $\$ 20.00$

Aeolus. B. Snow white perianth, large yellow trumpet, frilled and recurved brim . . . $5.25 \quad 40.00$

Bicolor Victoria. C. Perianth creamy white; trumpet yellow; first size . . ..... 110

Bicolor Victoria. Monster bulbs ......

Bulbocodium Conspicuus (Hoop Petticoat $)$. B. Golden yellow................ 3.25

Cervantes. B. Early; pale yellow trumpet. 1.15

Emerson. C. Light yellow perianth, rich yellow trumpet; good forcer...........

Emperor. C. Pure yellow trumpet, primrose perianth; first size . . . . . . . . . 1.10

Emperor. Monster bulbs .............. 1.30

Empress. C. White perianth, yellow trumpet, first size...

1.10

Empress. Monster bulbs................. 1.30

Fair Bostonian. C. White perianth, yellow trumpet; extra large . . . . . . . . . . . .

Giant Princeps. B. Perianth sulphur white,

trumpet rich yellow; monster bulbs.......
Glory of Sassenheim. B. White and yel-

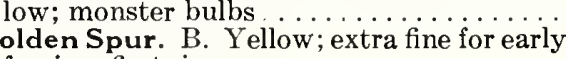

Golden Spur. B. Yel

$4.25 \quad 32.50$

Golden Spur. Monster bulbs.......... 1.25

Herbert Smith. C. Immense deep yellow trumpet, large yellow perianth.

King Alfred. B. Golden yellow; excellent for cut flower purposes; first size

King Alfred. Monster bulbs

Minister Talma. A. Large, bright yellow; early forcer

$1.00 \quad 7.25$

65.00

Mrs. E. H. Krelage. B. Often referred to as the "White King Alfred;" one of the finest pure white trumpet varieties

$1.00 \quad 7.00$

.75

$2.75 \quad 20.00$

$1.35 \quad 10.25$

$2.00 \quad 13.75$

95.00

$\begin{array}{lll}1.60 & 11.25 & 105.00\end{array}$

Olympia. B. Large yellow; monster bulbs .

Prince of Wales. C. Light yellow, bold and free flowering; long stems.

95.00

62.50

80.00
$1.25 \quad 8.75$

\section{GIANT TRUMPET VARIETIES-Continued}

Robert Sydenham. A. Sulphur yellow; excellent forcer .................\$2.75 \$20.00\$190.00

Spring Glory. B. Perianth white, trumpet yellow.................... $1.50 \quad 11.00 \quad 100.00$

Tresserve. B. Very large; light yellow ...... $1.75 \quad 12.50 \quad 115.00$

Van Waveren's Giant. B. Primrose peri-

anth, bright yellow trumpet; monster bulbs $2.75 \quad 21.00 \quad 200.00$

William Goldring. B. Pure white perianth,

primrose trumpet............. $3.25 \quad 22.50$

W. P. Milner. C. Sulphur trumpet. . . . . $3.25 \quad 22.50$

\section{MEDIUM TRUMPET VARIETIES}

Barrii Conspicuus. C. Perianth yellow, Doz. $100 \quad 1000$ dark yellow cup, edged scarlet . . . . . . .\$0.85 $\$ 5.75$

$\$ 50.00$

Bath's Flame. C. Deep yellow perianth; deeply edged orange red trumpet.......2.25 $\quad 16.50 \quad 155.00$

Incomparabilis Lucifer. C. Perianth white, trumpet orange scarlet. ..........

Incomparabilis Bernardino. C. Creamy

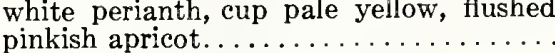

Leedsii, Mrs. Langtry. D. White.........
Leedsii, White Lady. C. White perianth, canary yellow cup.................

$\begin{array}{lll}1.00 & 6.75 & 60.00\end{array}$

Sir Watkin. C. Sulphur yellow, cup tinged with orange.

$1.15 \quad 8.25$

\section{ORCHID FLOWERED NARCISSUS THALIA}

This new variety has caused a sensation both in England and Holland and wherever shown; it is a real prize winner. Grows to a height of 15 inches or over; the color of this grand variety is white; 3 to 4 blooms are produced on a stem and so arranged as to remind one of orchid blooms; the flowers are of gigantic size and of the Triandus or Leedsii class. Excellent for February forcing, requiring the same treatment as all other Narcissus. Per doz., $\$ 10.50 ; \$ 80.00$ per 100 .

\section{POET'S AND POETAZ NARCISSUS}

Doz. 100

1000

Poetaz, Admiration. C. Pale yellow, cups

Poetaz, Elvira. B. Pure white, with delicate yellow cup; monster..............

Poetaz, Helios. C. Creamy yellow, pure

yellow cup..........................
Poetaz, Laurens Koster. B. Pure white, with orange yellow cup; monster..........
oetaz, Soliel Brilliant. A hardy form of

Poetaz, Soliel Brilliant. A hep orange cup $2.25 \quad 16.50 \quad 155.00$

Poeticus, Orange Cup. C. Creamy white,

cups orange; monster.................
Poeticus, Ornatus. C. White and scarlet; mammoth. ... $\begin{array}{lll}85 & 5.75 & \$ 50.00\end{array}$

$\begin{array}{lll}1.25 & 9.00 & 82.50\end{array}$

$\begin{array}{lll}.85 & 5.75 & 50.00\end{array}$

$8.25 \quad 75.00$

$5.75 \quad 50.00$ edged scarlet; monster.............. $\$ 3.25 \$ 22.50$ 


\section{MICHELL'S RELIABLE NARCISSUS BULBS}

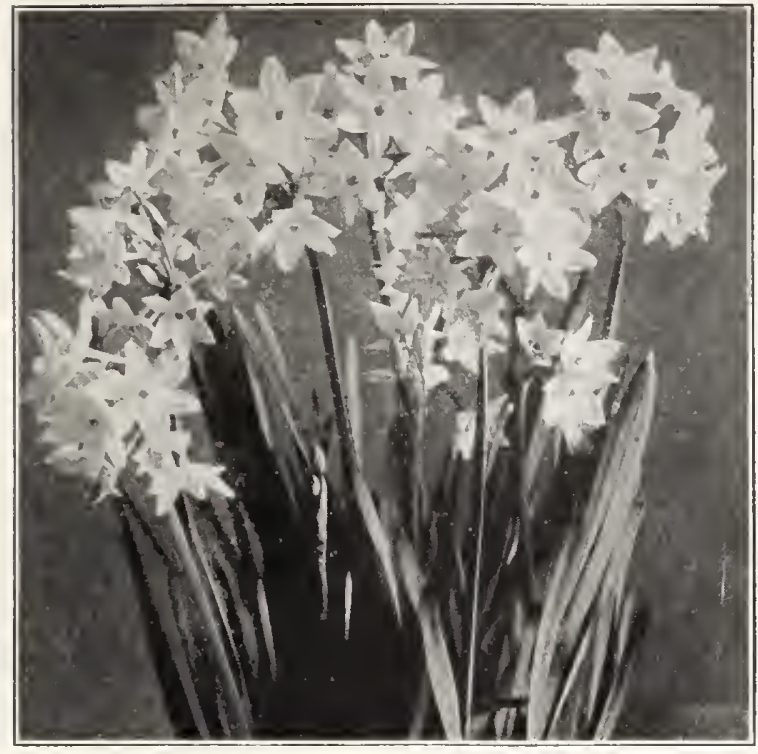

Narcissus, Big Bloom Paper White

\section{NARCISSUS, POLYANTHUS VARIETIES}

If wanted by Parcel Post, add 15c. per doz.; 40c. per 100, for postage.

Michell's Big Bloom Paper White

$5,000 \quad 10,000$

lots lots

per per

Doz. $100 \quad 1000 \quad .1000 \quad 1000$

First size, 13 ctm. up....... \$0.45 $\$ 3.00 \$ 25.00 \$ 24.00 \$ 23.50$

Mammoth, 14 ctm. up ..... $.55 \quad 3.50 \quad 28.50 \quad 27.50 \quad 27.00$

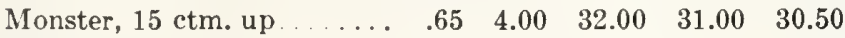

Jumbo, 16 ctm. up ........ $\quad .75 \quad 4.25 \quad 36.00 \quad 35.00 \quad 34.50$

Write for prices on larger quantities of Paper White Grandiflora Narcissus.

Grand Soleil d'Or. Rich yellow with orange

Doz. $100 \quad 1000$ red cup.

13 to $14 \mathrm{ctm} . .$.

$\$ 1.15 \$ 8.00 \$ 75.00$

14 to $15 \mathrm{ctm}$.

$1.25 \quad 9.25 \quad 87.50$

\section{NARCISSUS, DOUBLE VARIETIES}

If wanted by Parcel Post, add 15c. per doz.; 40c. per 100, for postage.

Alba Plena Odorata Aoz. $100 \quad 1000$ Incomparable. C. Yellow and orange...... $1.15 \quad 8.25 \quad 75.00$ Orange Phoenix. C. White, orange center.... $1.25 \quad 8.75 \quad 80.00$ Primrose Phoenix. C. Primrose yellow ..... $1.60 \quad 11.25 \quad 105.00$ Sulphur Phoenix. C. Creamy white with

sulphur yellow center. $\begin{array}{lllll}1.25 & 8.75 & 80.00\end{array}$

Von Sion. C. Golden yellow; first size . . . . . . $\quad .90 \quad 6.50 \quad 57.50$

Von Sion. Monster................. $1.25 \quad 8.50 \quad 77.50$

\section{NARCISSUS, IN MIXTURE}

We offer an excellent mixture, which can be depended upon for best results. Extra large bulbs, per doz., 75c. (by Parcel Post, 90c.); $\$ 5.25$ per 100 (by Parcel Post, $\$ 5.65$ ); per $1000, \$ 45.00$.

Treat your bulbs with Semesan before planting.

\section{CHINESE SACRED LILY BULBS}

These sell readily on the store counter, and yield a handsome profit. We would recommend to force a few into flower, which can be done in about five weeks, and place the bulbs you desire to sell on the counter with the blooming plant.

If wanted by Parcel Post, add 20c. per doz. for postage.

Monster Size Bulbs

Doz. $100 \quad 1000$

$\$ 0.85 \quad \$ 6.00 \quad \$ 55.00$

Show and price cards on Chinese Lilies furnished free.

Note.-If Chinese Lilies are to be grown in water, they will flower more satisfactorily if not started until late, thus giving the bulbs time to be thoroughly ripened and cured.

\section{GOLDEN CHINESE LILY}

Doz. $\quad 100 \quad 1000$

Clusters of rich yellow flowers; deep, orange red cup. Mammoth bulbs ........\$1.25 $\$ 9.25 \quad \$ 87.50$

\section{PEBBLES FOR CHINESE LILIES}

Per qt., 8c.; 85c. per doz. qt. packages; per $100, \$ 6.50 ; 50$ at 100 rate. In bulk, $55 \mathrm{c}$. per pk.; bu., $\$ 2.00 ; \$ 4.00$ per bbl. sack.

PEARL CHIPS FOR BULB BOWLS, ETC.

White or assorted colors. 15c. per pkg.; 6 pkgs. for $80 \mathrm{c}$; $\$ 1.50$ per 12 pkgs.; 25 pkgs. for $\$ 3.00 ; \$ 11.00$ per 100 pkgs. In bulk, 5 lbs., $65 \mathrm{c}$.; $\$ 1.25$ per 10 lbs.; 25 lbs., $\$ 2.75 ; \$ 5.00$ per 50 lbs.; 100 lbs., $\$ 9.00$.

\section{JONQUILS}

These are perfectly hardy and are suitable for either outdoor planting or forcing. They are delightfully fragrant, and are worthy of extensive cultivation.

If wanted by Parcel Post, add 15c. per doz.; 40c. per 100, for postage.

Campernelle Rugulosus Single yellow,

larger than the plain Campernelle...... \$0.85 $\$ 6.00 \quad \$ 55.00$

Golden Sceptre. Elegant flowers on stems averaging 20 inches in height; color, rich golden yellow; sweet scented........... $1.10 \quad 7.75 \quad 70.00$

Double (Odorous Plenus). Flowers very

double, deep golden yellow .............. $\quad .85 \quad 6.00 \quad 55.00$ Single. Rich yellow, very fragrant....... $\quad .80 \quad 5.75 \quad 52.50$

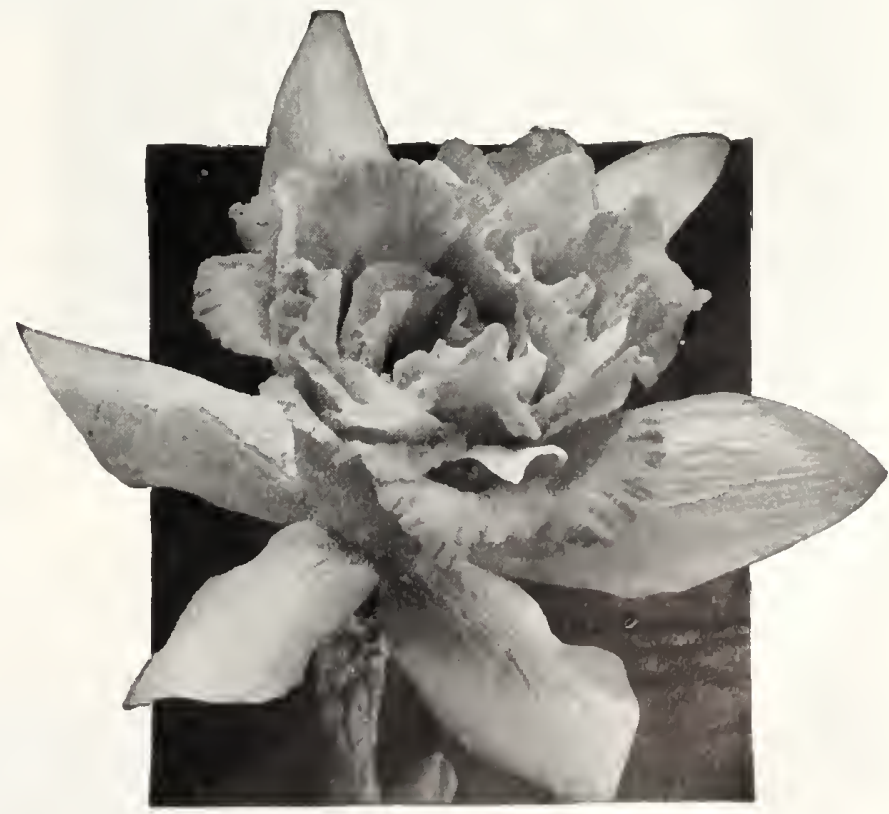

Double Narcissus, Von Sion 


\section{CALLA LILIES}

WHITE CALLAS (AETHIOPICA)

Clean healthy bulbs.

Doz. $100 \quad 1000$

diameter.........\$1.00 \$6.50 $\$ 58.50$

$11 / 2$ to $13 / 4$ inches in diameter . . . . . . . $1.65 \quad 12.50 \quad 120.00$

$13 / 4$ to 2 inches in diameter ................ $2.25 \quad 16.50 \quad 158.00$

2 to $2 \frac{1}{2}$ inches in diameter........... $3.50 \quad 24.50 \quad 238.00$

\section{GODFREY EVERBLOOMING CALLA} sales.

This is a popular variety for either cut-flower or pot-plant

$\begin{array}{lll}\text { Doz. } 100 \quad 1000 & \end{array}$

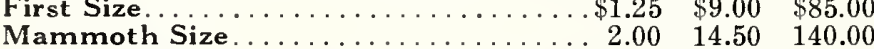

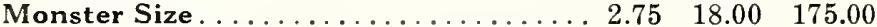

YELLOW CALLA (ELLIOTTIANA) (True)

(Ready in November)

Doz. $100 \quad 1000$

Mammoth Size. 2 to $21 / 2$ inches diameter. $\$ 2.75 \$ 19.50 \$ 190.00$ Monster Size. $21 / 2$ to 3 inches diameter . . . $3.50 \quad 26.00 \quad 255.00$ Jumbo Size. 3 to $3 \frac{1}{2}$ inches diameter . . . . $4.75 \quad 35.00 \quad 345.00$

\section{SPOTTED CALLAS}

Flowers white; foliage green, spotted white. Ready in November. Large bulbs, $\$ 2.75$ per doz.; per $100, \$ 18.00 ; \$ 175.00$ per 1000 .

If Callas are wanted by Parcel Post, add 20c. per doz., for postage.

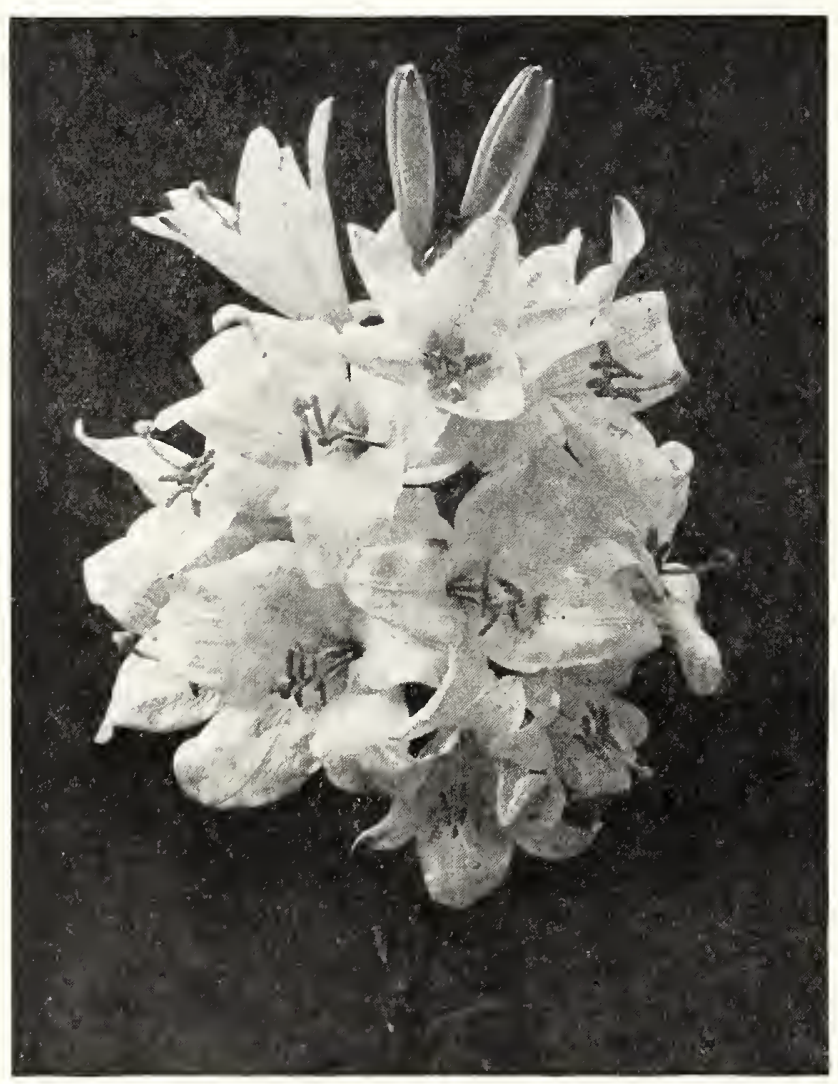

Lilium Candidum

\section{LILIUM CANDIDUM}

Madonna, Annunciation or St. Joseph's Lily)

We wish to lay particular stress upon the quality of our Lilium Candidum, which are larger and better than usually sold. Our bulbs are of strong, healthy growth, free from disease and produce an ab undance of thick petaled flowers.

\begin{tabular}{|c|c|c|c|c|}
\hline 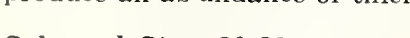 & Doz. & By P.P. & 100 & 1000 \\
\hline $20-Z 2 \mathrm{ctm}$ & $\$ 1.25$ & $\$ 1.40$ & $\$ 8.75$ & $\$ 80.00$ \\
\hline & 1. & 1.70 & 10.75 & 100.00 \\
\hline Siz & 1.? & 2.00 & 12.75 & 120.00 \\
\hline size, $26 \mathrm{ctm}$. and $\mathrm{u}$ & ? & 2.55 & 16.50 & 155.00 \\
\hline
\end{tabular}

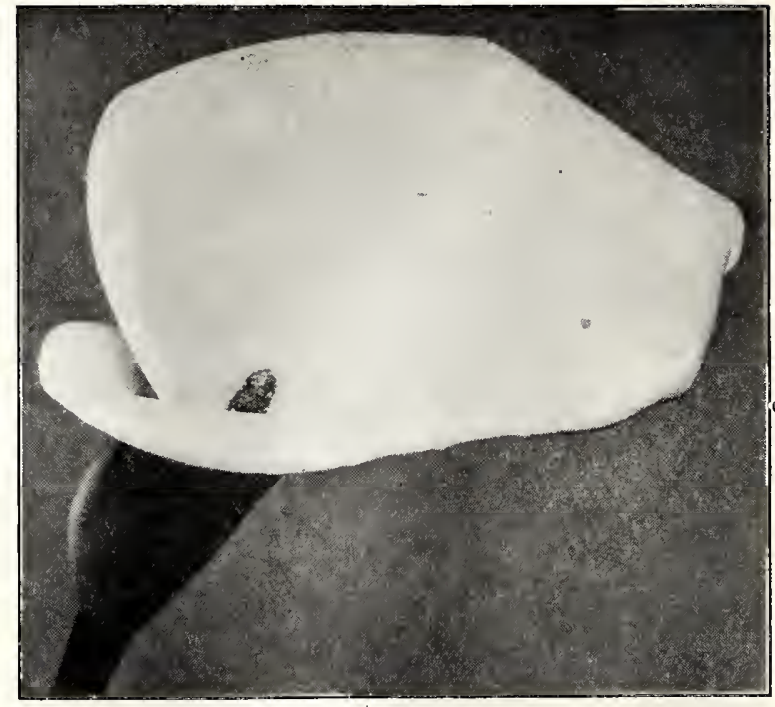

White Calla

\section{HARDY JAPANESE LILIES Special Notice Regarding Delivery}

Most of the varieties listed below will arrive in time for fall planting. It often happens however that some varieties reach us too late for autumn planting. Orders for these will be held for early spring delivery. When ordering please specify if you desire fall or spring delivery.

It is advisable to prepare your lily bed in the early autumn and cover with 3 or 4 inches of litter, this will preven freezing and will permit safe planting of the late arrivals.

Lilium Album (Praecox). Pure white.

“ Auraturn (Golden Banded Lily)....... Prices will be

“ Magnificum. Rich crimson....... established later.

“ Melpomene. Pink spotted red.

“ Rubrum or Roseum. Pink.

We can supply the above in 8 to 9 inch; 9 to 11 inch; 11 to 13 inch.

“ Tigrinum Flore Pleno. Double.... Doz. $\quad \begin{aligned} & 100 \\ & \$ 2.75\end{aligned}$

“ Tigrinum Splendens. Single......... $2.75 \quad 18.00$

Auratum Platyphyllum (Macranthum). Giant

Golden Banded Lily.

$3.25 \quad 22.00$

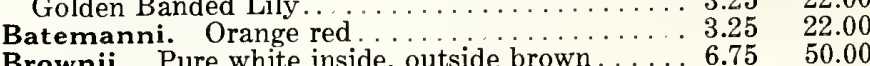

Brownii. Pure white inside, outside brown..... $6.75 \quad 50.00$

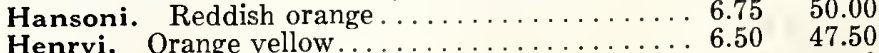

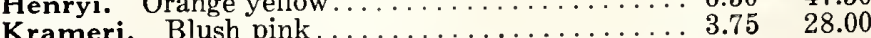

\section{MISCELLANEOUS HARDY LILIES} (Ready in October)

Doz. 100

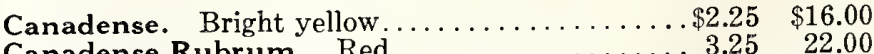

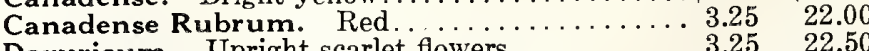

$\begin{array}{llll}\text { Davuricum. Upright scarlet flowers . . . . . . . . } 3.25 & 22.50 \\ \text {. } & 1.75 & 12.00\end{array}$

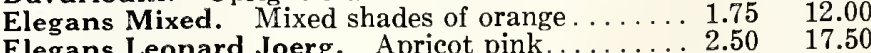

Elegans Leonard Joerg. Apricot pink......... $2.575 \quad 17.50$

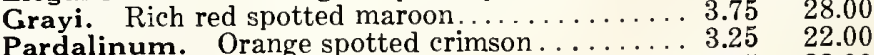

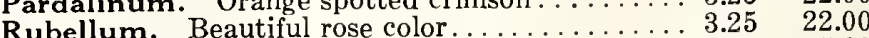

Superbum. Orange red ...............2.25 15.00

Szovietzianum Colchicum. Yellow ......... $6.75 \quad 50.00$

White outside, inside pale apricot... 2.75 27.50

e. 30.00

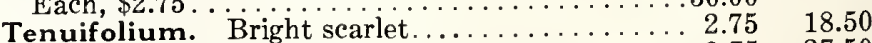

Umbellatum. Orange scarlet............. $3.75 \quad 27.50$

\section{LILY REGALE OR MYRIOPHYLLUM}

Doz. $100 \quad 1000$

$\$ 2.00 \$ 14.00 \$ 130.00$

6 to 7 inches..................... $2.00 \quad \$ 21.00 \quad 200.00$

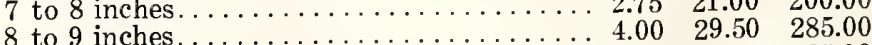

9 inches and up.................. $5.50 \quad 43.50 \quad 425.00$

If Lilies are wanted by Parcel Post, add 25c. per doz., for postage. 


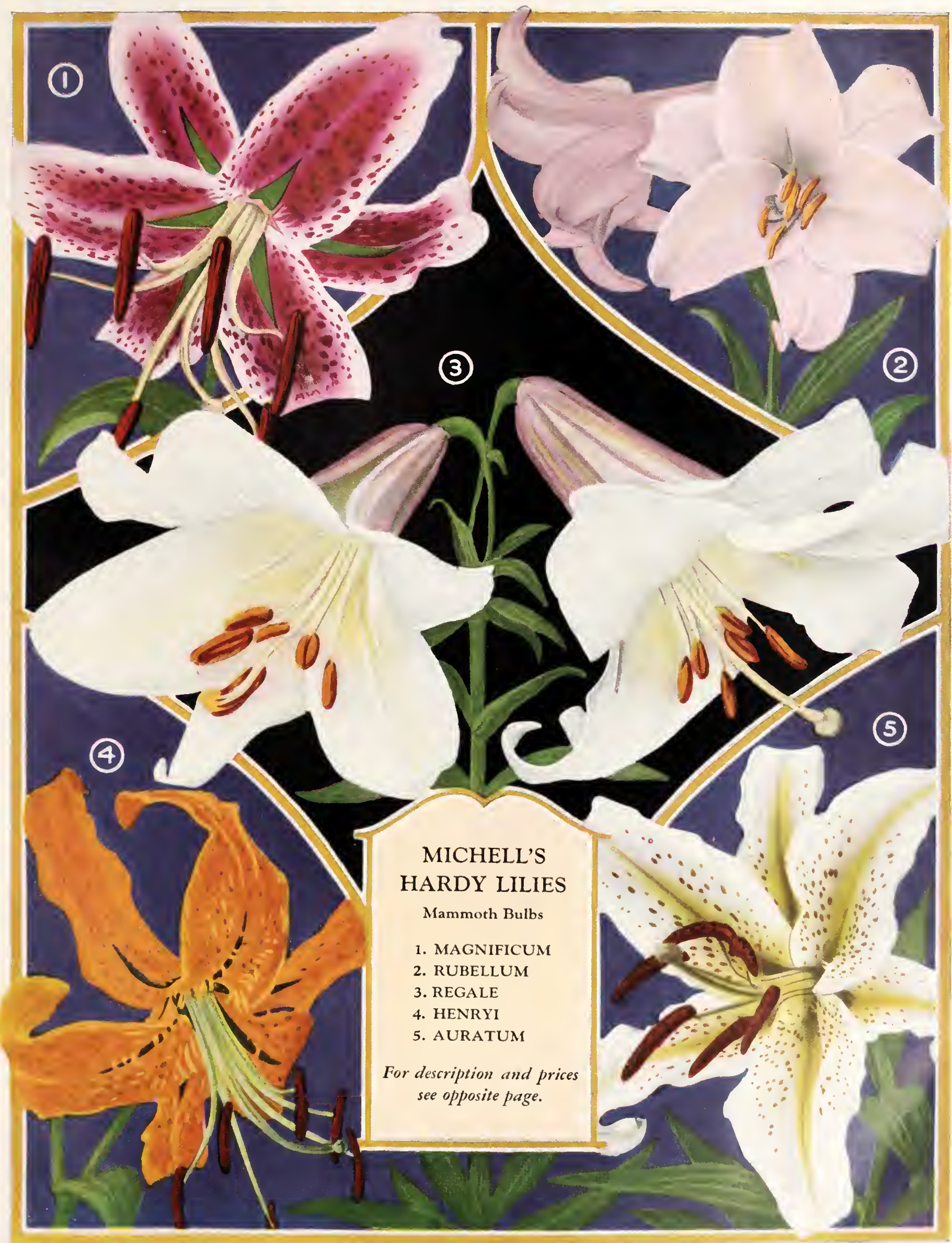




\section{${ }^{8 A}$ MICHELL'S SUPERB EASTER LILY BULBS}

Our house is among the largest direct importers, paying particular care to quality and grading; all bulbs are of standard packing and selected from best cultures.

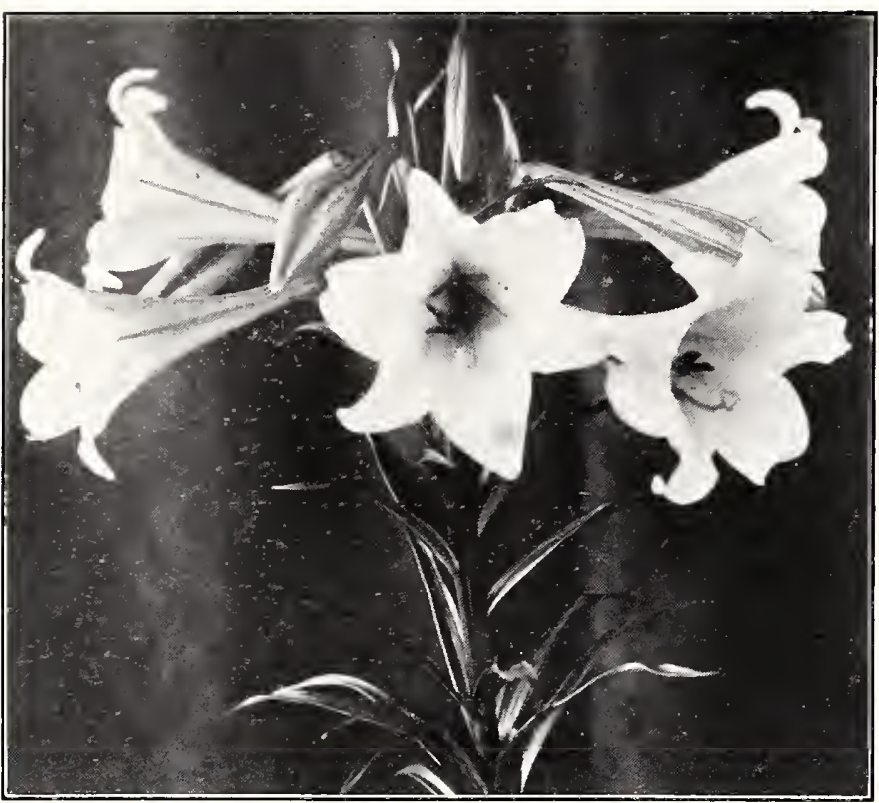

Lilium Erabu

\section{EASTER IN 1932 COMES ON MARCH 27th}

\section{LILIUM HARRISII \\ MICHELL'S SPECIAL BRAND}

These are the cream of the Bermuda Lily Crop, being a selection of bulbs from the most uniform plants. Our Harrisii last season gave the best of results and our growers assure us the same quality for this season. We recommend this lily for early spring flowering.
Size

6 to 7 inch

7 to 9 inch

8 to 10 inch

9 to 11 inch.
Bulbs per case

200

200

100
Doz. 100 Per Case $\$ 1.60 \quad \$ 9.50 \quad \$ 26.50$ $\begin{array}{lll}2.25 & 15.50 & 26.50\end{array}$ $\begin{array}{lll}2.75 & 20.00 & 26.50\end{array}$ $\begin{array}{lll}3.50 & 26.50 & 26.50\end{array}$

\section{LILIUM LONGIFLORUM GIGANTEUM MICHELL'S SPECIAL FORCING BRAND} True Northern Mountain Grown

Grown for us by the most reliable Lily-growers in Japan.
Size

6 to 8 inch

7 to 9 inch

7 to 9 inch

8 to 9 inch

8 to 10 inch

8 to 10 inch

9 to 10 inch

9 to 10 inch

10 to 12 inch.
Bulbs per case

$400 \ldots \ldots$
$100 \ldots \ldots$
$300 \ldots \ldots$
$.250 \ldots \ldots$
$100 \ldots \ldots$
$225 \ldots \ldots$
$100 \ldots \ldots$
$200 \ldots \ldots$
$150 \ldots \ldots$

\section{LILIUM LONGIFLORUM GIGANTEUM MICHELL'S BONIN TYPE \\ Southern Japan Grown}

This type is taller growing than our regular brand of Giganteum and produces larger blooms. It is recommended for early flowering, which should be followed up with our regular brand for

\begin{tabular}{|c|c|}
\hline Size & Bulbs per case \\
\hline 6 to 8 inch & $\ldots .400 \ldots$ \\
\hline 7 to 9 inch & .300 \\
\hline 8 to 9 inch & 250 \\
\hline $\begin{array}{l}8 \text { to } 10 \text { inch } \\
9 \text { to } 10 \mathrm{inch}\end{array}$ & 225. \\
\hline
\end{tabular}

Prices will be established later later crops.

\section{LILI UM LONGIFLORUM MULTIFLORUM \\ True Narrow Leaf Type}

We carry the true narrow leaf strain which is the only type to use for best results.

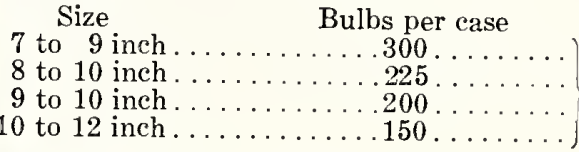

Prices will be established later

\section{LILIUM NOBILI}

A new Easter Lily, highly recommended for pot culture, requiring treatment similar to that of Multiflorum; flowers large and of heavy texture.

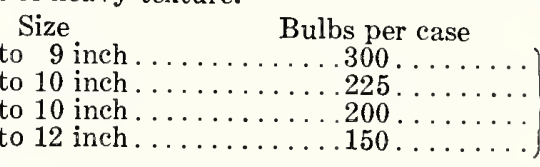

Prices will be established later

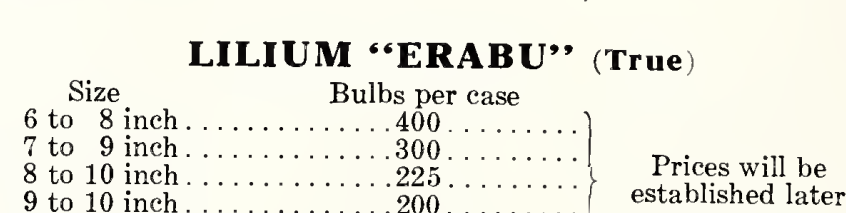

established later
Prices will be established later

\section{LILIUM SINENSIS (True)}

A new variety of proven merit, requiring treatment similar to the Harrisii; should not be subjected to either extreme heat or cold; large flowers of heavy texture and deep glossy foliage; grows fairly tall.
Size

7 to 9 inch

9 to 10 inch.
8 to 10 inch
Bulbs per case 300 . 225 . 200
Prices will be established later

\section{LILIUM FORMOSUM (Dark-Stem Type) Erabu Isle Grown \\ Size Bulbs per case} 6 to 8 inch..........400....

7 to 9 inch ................

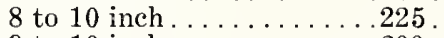

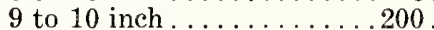

10 to 12 inch........... 150 . .

Prices will be established later
Please note that Japanese Lily Bulbs are shipped upon arrival; we will be glad however to retain them in cold storage for your account for shipment as you desire, at a cost of 25 c. per case, per month, commencing December 1 st.

\section{COLD STORAGE LILIES}

We carry a complete line of all Lilies in cold storage, that are profit providers for the florist. Let us quote you on your requirements. 


\section{MICHELL'S MISCELLANEOUS BULBS AND ROOTS}

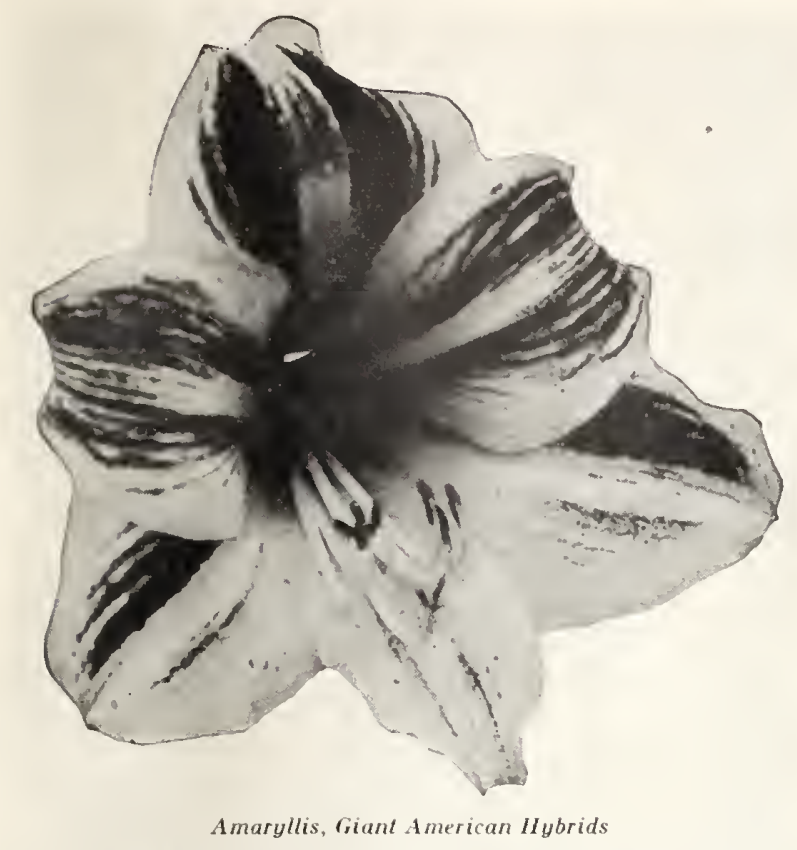

AMARYLLIS Ready in October)

Florists will find Amaryllis a splendid pot plant for store sales; they can be flowered in a remarkably short time and will sell on sight when in bloom at a good price.

If wanted by Parcel Post, add 25c. per doz. for postage.

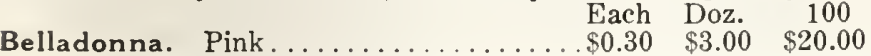

Formosissima. Crimson ............... $50 \quad 5.25 \quad 40.00$

Hippeastrum Equestre. Bright red......... $.30 \quad 3.00 \quad 20.00$

Giant American Hybrids. The finest race

of Amaryllis in cultivation; flowers are

beautifully striped and flaked. Large

bulbs.

$\begin{array}{lll}.50 & 5.25 & 40.00\end{array}$

\section{$\begin{array}{ccc}\text { ACONITE } \\ \begin{array}{c}\text { (Erianthus) } \\ \text { Doz. } 100\end{array} & \text { By P.P. } 1000\end{array}$

$\begin{array}{llll}\text { Doz. } & 100 & \text { By P.P. } & 1000 \\ \$ 0.45 & \$ 2.50 & \$ 2.65 & \$ 18.50\end{array}$

Winter

\section{BEGONIAS (Tuberous Rooted)}

(Ready about January 1st)

Very choicest giant flowering type.

If wanted by Parcel Post, add 10c. per doz.; 25c. per 100, for postage.

Single Begonias (Large Bulbs)

Doz. $\quad 100 \quad 1000$

Crimson. $\$ 1.75 \$ 12.50 \$ 120.00 \quad$ Scarlet. $\$ 1.75 \quad \$ 12.50 \quad \$ 120.00$

$\begin{array}{lllllllll}\text { Orange. } & 1.75 & 12.50 & 120.00 & \text { White... } & 1.75 & 12.50 & 120.00\end{array}$

$\begin{array}{llllll}\text { Pink and } & \text { Yellow } & 1.75 & 12.50 & 120.00\end{array}$

$\begin{array}{llllllll}\text { Rose... } & 1.75 & 12.50 & 120.00 & \text { Mixed... } & 1.75 & 12.50 & 120.00\end{array}$

Salmon.. $1.75 \quad 12.50 \quad 120.00$

Double Begonias (Large Bulbs)

$\begin{array}{llllll}\text { Doz. } & 100 & 1000 & \text { Doz. } & 100 & 1000\end{array}$

Crimson. $\$ 2.00 \quad \$ 13.50 \$ 130.00 \quad$ Scarlet. $\$ 2.00 \quad \$ 13.50 \$ 130.00$

$\begin{array}{llllllll}\text { Orange. . 2.00 } & 13.50 & 130.00 & \text { White. . 2.00 } & 13.50 & 130.00\end{array}$

$\begin{array}{llllll}\text { Pink and } & & \text { Yellow... 2.00 } & 13.50 & 130.00\end{array}$

\begin{tabular}{lll|lllll} 
Rose... 2.00 & 13.50 & 130.00 & Mixed .. 2.00 & 13.50 & 130.00
\end{tabular}

Salmon $2.00-13.50-130.00$

\section{BEGONIA CRISPA (Large Bulbs)}

A beautiful frilled or crested type, producing very large single flowers.

Doz. $100 \quad 1000$

Orange. $\$ 2.25 \$ 14.50 \$ 140.00$

Pink and

$\begin{array}{llllllll}\text { Rose... 2.25 } & 14.50 & 140.00 & \text { Yellow. . 2.25 } & 14.50 & 140.00\end{array}$

\begin{tabular}{llll|lll} 
Salmon.. 2.25 & 14.50 & 140.00 & Mixed... 2.25 & 14.50 & 140.00
\end{tabular}

BEGONIA, HANGING BASKET TYPE

Unsurpassed for vases and hanging baskets, also porch and window boxes.

Mixed Colors

Doz. $\quad 100 \quad 1000$

$\$ 2.25 \$ 14.50 \$ 140.00$

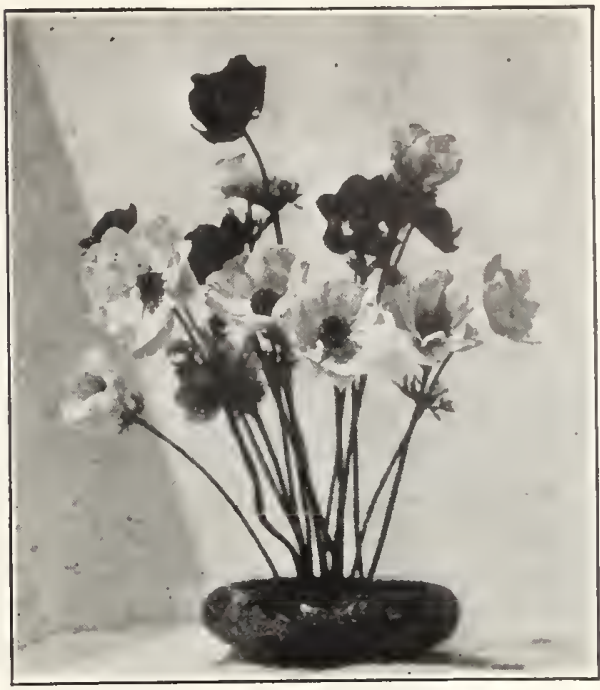

Anemone

\section{ANEMONE (Ready in October)}

These make delightful flowering plants for pot culture and will sell readily with any florist who has a store trade. They require little attention and grow easily in a cool greenhouse. Plant 3 bulbs in a 4 -inch pot. The pots can be placed immediately on the bench, or under the bench; if the latter, bring them to the top when about an inch high, where the plant will develop.

DeCaen. Single French, mixed Doz. 100 By P.P. 1000

His Excellency. Large flowering

Poppy Anemone; deep scarlet, thick petals, long stems

St. Brigid. Semi-double, various colors ................. $65 \quad 3.75 \quad 3.90 \quad 32.50$

\section{BRODIAEAS}

Choice Mixed. A small bulb producing grassy leaves near the ground; slender, stiff stems with small waxy flowers in shades of blue and purple. Doz., 70c.; $\$ 4.00$ per 100 ; per $1000, \$ 35.00$.

\section{FANCY LEAVED CALADIUMS (Ready in January}

These are grown for us on contract by one of the leading hybridizers of the world. Our list is composed of the best named standard and newer sorts, including the best of the Brazilian types and cover a wide range of the brightest colorings and markings, which are difficult to describe accurately. Do not allow them to get chilled, and at all times grow them in a warm, shaded place.

Strictly First Size Bulbs, in highly colored, choice named varieties. Per doz., $\$ 2.75$ (by parcel post, $\$ 2.85$ ); $\$ 17.00$ per 100 (by parcel post, $\$ 17.25$ ); per $1000, \$ 165.00$.

Mixed Varieties. Per doz., \$2.25 (by parcel post, \$2.35); $\$ 14.50$ per 100 (by parcel post, $\$ 14.75$ ); per $1000, \$ 140.00$.

\section{CALLAS, See Page 8 CALOCHORTUS OR MARIPOSA TULIP (Also Known as Butterfly Tullp)}

Mixed Colors. Our mixture comprises all the pleasing shades, pink, rose, white, lavender and primrose. Doz., 75c.; $\$ 4.50$ per 100; per $1000, \$ 40.00$.

\section{CAMASSIA}

Leichtlini. A hardy bulbous plant thriving under ordinary garden conditions or when naturalized in open moist woods or in not too dense a grassy growth. Stems 4 feet high with as many as 100 large, star-shaped flowers to a stem. Color, shades of deep blue and creamy white. Doz., $\$ 1.10 ; \$ 7.50$ per 100 ; per 1000 , $\$ 70.00$.

\section{CANNAS}

We will have an extensive list of these to offer for next spring, including the newer varieties. Send us your list of requirements for special prices. Complete list with prices ready November 15 th. 


\section{MICHELL'S MISCELLANEOUS BULBS AND ROOTS}

\section{CHIONODOXA (Glory of the Snow)}

Doz. 100 By P.P. 1000

Luciliae. Porcelain blue..... $\ldots . \ldots 0.45 \quad \$ 2.50 \quad \$ 2.65 \quad \$ 20.00$ $\begin{array}{llllll}\text { Sardensis. Deep blue............. } & .50 & 2.75 & 2.90 & 22.00\end{array}$

\section{CROCUS}

If wanted by Parcel Post, add 15c. per 100 for postage.

\begin{tabular}{|c|c|c|c|}
\hline & Doz. & 100 & 1000 \\
\hline aron von Brunow. Blue. & $\$ 0.45$ & $\$ 2.50$ & $\$ 20.00$ \\
\hline loth of Gold. Yellow ............ & .45 & 2.50 & 20.00 \\
\hline ing of the Blues. Purple. & 45 & 2.50 & 20.00 \\
\hline t Blanc. White..... & .45 & 2.50 & 20.00 \\
\hline urpurea Grandiflora. Rich purple. . & .45 & 2.50 & 20.00 \\
\hline tt. White, striped lilac... . . & .45 & 2.50 & 20.00 \\
\hline & .35 & 2.00 & 15.00 \\
\hline d & .35 & 2.00 & 15.00 \\
\hline & .35 & 2.00 & 15 \\
\hline ow. Extra large monster & .60 & 3.50 & 30 \\
\hline ellow. Mammoth. & .50 & 3.00 & 25 \\
\hline llow. First size & .45 & 2.50 & \\
\hline All & .30 & 1.75 & 14.00 \\
\hline am & .45 & 2.50 & 20.00 \\
\hline
\end{tabular}

\section{AUTUMN FLOWERING CROCUS}

\section{(Colchicum Autumnale)}

This variety will bloom without soil or water by placing in the sun in a dish or saucer; lavender colored flowers. An excellent novelty for counter trade. Extra large bulbs. $\$ 4.25$ per doz.; per $100, \$ 32.00$.

\section{DIELYTRA OR DICENTRA (Bleeding Heart)}

Spectabilis. Excellent for forcing. $\$ 3.50$ per 10 ; per $100, \$ 30.00$.

\section{ERYTHRONIUM (Dog's Tooth Violet)}

Revoluta. Charming woodland plants; lily-like flowers in various shades of white, pink, creamy yellow and rose; mottled leaves. Doz., 80c.; $\$ 5.50$ per 100 ; per 1000, $\$ 50.00$.

\section{FREESIA, PURITY (True}

\begin{tabular}{lrrrrr} 
& & & & per & per \\
& Doz. & \multicolumn{1}{c}{100} & 1000 & 1000 & 1000 \\
First size, $1 / 2$ to $5 / 8$ inch..... $\$ 0.20$ & $\$ 1.00$ & $\$ 7.50$ & $\$ 6.50$ & $\$ 6.00$ \\
Mammoth, $5 / 8$ to $3 / 4$ inch..... & .35 & 2.25 & 17.00 & 16.00 & 15.50 \\
Monster, $3 / 4$ to $7 / 8$ inch...... & .50 & 3.00 & 25.00 & 24.00 & 23.50 \\
Jumbo Bulbs, $7 / 8$ inch and up. & .65 & 4.25 & 37.50 & &
\end{tabular}

\section{ELDER'S GIANT WHITE FREESIA}

Giant pure white blooms, with very long stems.

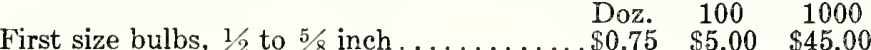
Mammoth bulbs, $5 / 8$ to $3 / 4$ inch .......... $85 \quad 5.50 \quad 50.00$

\section{COLORED FREESIAS}

California. Bright golden yellow.

Doz. $100 \quad 1000$

First size bulbs, $1 / 2$ to $5 / 8$ inch $\ldots \$ 0.45$

Mammoth bulbs, $5 / 8$ to $3 / 4$ inch........ .55

Carmencita. Orange-salmon, buff shading. First size bulbs, $1 / 2$ to $5 / 8$ inch...... $\quad 45 \quad 3.00 \quad 24.00$

Mammoth bulbs, $5 / 8$ to $3 / 4$ inch.......

Carrie Budau. Lavender pink.

First size bulbs, $1 / 2$ to $5 / 8$ inch . . . . . . . . .65 $4.25 \quad 36.00$

Mammoth bulbs, $5 / 8$ to $3 / 4$ inch........

Coreo. Bright orange red.

First size bulbs, $1 / 2$ to $5 / 8$ inch . . . . . . . .65 $4.25 \quad 36.00$

Mammoth bulbs, $5 / 8$ to $3 / 4$ inch........ $\quad .75 \quad 4.75 \quad 39.00$

General Pershing. Bronzy pink.

First size bulbs, $1 / 2$ to $5 / 8$ inch........ $.35 \quad 2.50 \quad 19.00$

Mammoth bulbs, $5 / 8$ to $3 / 4$ inch.........

Golden Daffodil. Golden yellow with or-

ange blotch on lower lip.

First size bulbs, $1 / 2$ to $5 / 8$ inch . . . . . . . .50 $3.50 \quad 30.00$

Mammoth bulbs, $5 / 8$ to $3 / 4$ inch........ $.60 \quad 4.00 \quad 35.00$

Monster bulbs, $3 / 4$ to $7 / 8$ inch ........... $70 \quad .70 \quad 4.50 \quad 40.00$

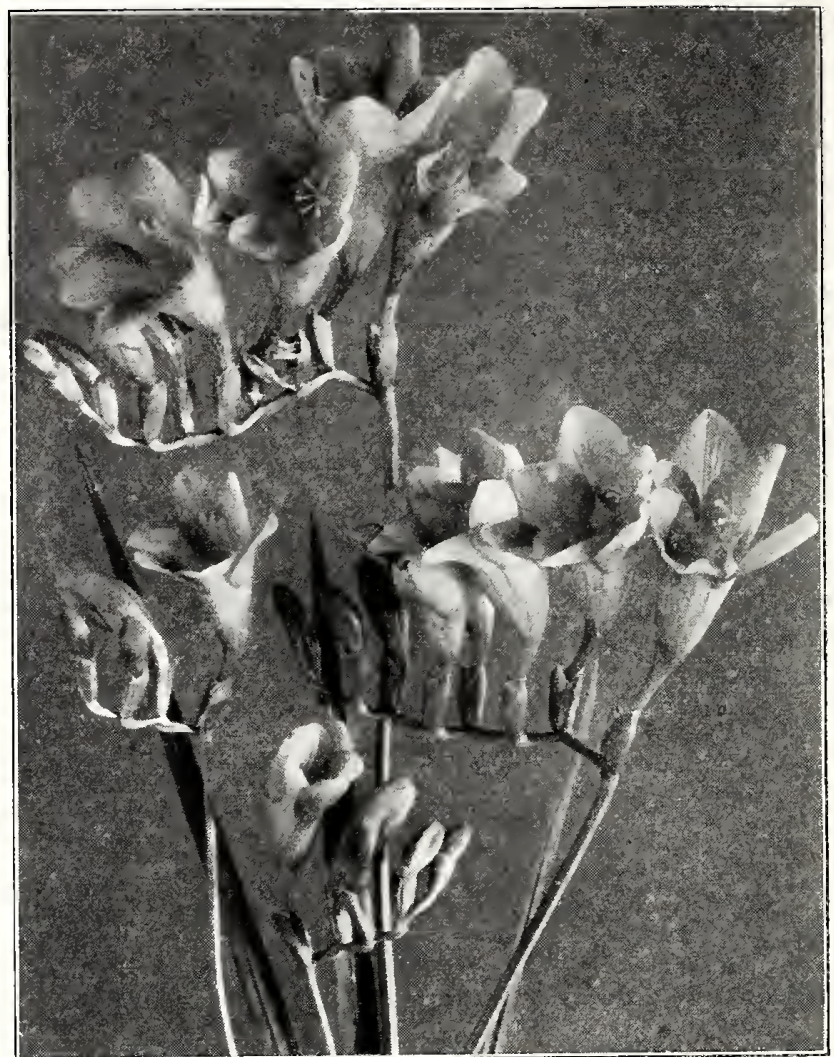

Freesia, Golden Daffodil

Golden Treasure. Light yellow with lavender marking on center of each petal.

First size bulbs, $1 / 2$ to $5 / 8$ inch. ........\$0.50 $\$ 3.50 \quad \$ 30.00$

Mammoth bulbs, $5 / 8$ to $3 / 4$ inch ....... $\quad .60 \quad 4.00 \quad 35.00$

Monster bulbs, $3 / 4$ to $7 / 8$ inch.......... $\quad .70 \quad 4.50 \quad 40.00$

June Michelsen. Deep rose pink with white

throat; lower petals veined crimson.

First size bulbs, $1 / 2$ to $5 / 8$ inch . . . . . . . .75 $5.25 \quad 46.00$

Mammoth bulbs, $5 / 8$ to $3 / 4$ inch........ $\quad .85 \quad 5.50 \quad 50.00$

Mendota. A new giant yellow variety.

First size bulbs, $1 / 2$ to $5 / 8$ inch. . . . . . . $\quad .50 \quad 3.75 \quad 31.00$

Mammoth bulbs, $5 / 8$ to $3 / 4$ inch.......

Mrs. Marc Peters. Deep rosy salmon,

blotched golden yellow; very early.

First size bulbs, $1 / 2$ to $5 / 8$ inch ....... $\quad .75 \quad 5.25 \quad 46.00$

Mammoth bulbs, $5 / 8$ to $3 / 4$ inch ........ $\quad .85 \quad 5.50 \quad 50.00$

Splendens. Lavender.

First size bulbs, $1 / 2$ to $5 / 8$ inch...... $\quad .35 \quad 2.50 \quad 19.00$

Mammoth bulbs, $5 / 8$ to $3 / 4$ inch.......

Yellow Prince. Deep yellow.

First size bulbs, $1 / 2$ to $5 / 8$ inch . . . . . . . $45 \quad 3.00 \quad 24.00$

Mammoth bulbs, $5 / 8$ to $3 / 4$ inch . . . . . $\quad .55 \quad 3.25 \quad 27.00$

Rainbow Mixture.

First size bulbs, $1 / 2$ to $5 / 8$ inch ....... . . . $35 \quad 2.50 \quad 19.00$

$\begin{array}{lllll}\text { Mammoth bulbs, } 5 / 8 \text { to } 3 / 4 \text { inch ....... } & .45 & 2.75 & 22.00\end{array}$

FRITILLARIA IMPERIALIS (Crown Imperial)

Doz. $\quad 100$

Mixed Colors

$\$ 4.00 \$ 30.00$

FRITILLARIA MELEAGRIS

Doz. $100 \quad 1000$

Very Fine Mixed ...................\$0.70 \$4.00 \$35.00 


\section{MICHELL'S MISCELLANEOUS BULBS AND ROOTS}

\section{BABY GLADIOLUS (FOR FORCING) COLVILLEI TYPE (Ready in October)}

The demand for these as a late Winter and early Spring flower under glass is constantly on the increase. They require little attention and are practically immune from attacks by insects or plant diseases.

$\begin{array}{lll}\text { Doz. } & 100 & 1000\end{array}$ California Pink Perfection. Rich pink. .\$0.70 $\$ 4.50 \quad \$ 39.00$ Fiery Night. Brilliant carmine........ . .70 $4.50 \quad 39.00$ Peach Blossom. Soft pink........... .60 $\quad 3.75 \quad 32.00$ The Bride. Pure white............. .50 $3.50 \quad 30.00$

Also the Primulinus and regular type of Gladiolus in special forcing varieties. List and prices upon application.

\section{GLOXINIAS}

(Ready about January 1st

We offer extra fine large bulbs.

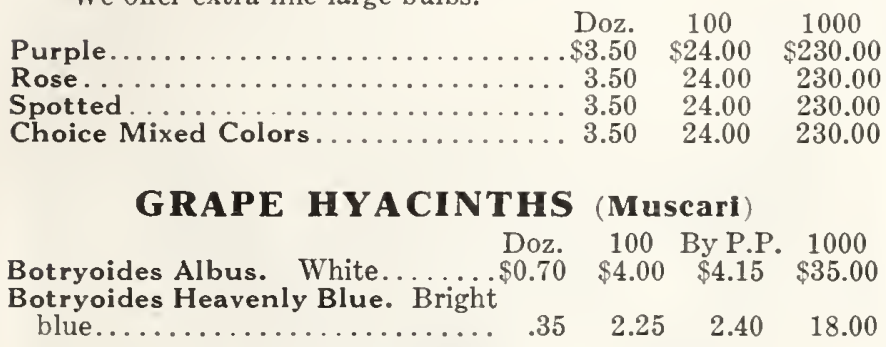

\section{HYACINTHS. See pages 4 and 5}

\section{SPANISH IRIS (Ready in October)}

The flowers are beautiful and very delicate; used for bedding or forcing. For the latter purpose, they should be planted thickly in flats, wintered in a cool place and brought to heat gradually. They take little space in the greenhouse and require little or no special attention after planting.

On all our Iris we offer the largest size bulbs, grown and selected for forcing.

If Iris is wanted by Parcel Post, add 15c. per 100, for postage.

Cajanus. Canary yellow, with orange Doz. $100 \quad 1000$

blotches................................. $\$ 0.25 \quad \$ 37.50$

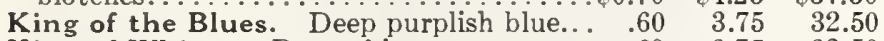
King of Whites. Pure white.......... $.60 \quad 3.75 \quad 32.50$ Prince Henry. Bronze................. .70 $4.25 \quad 37.50$

\section{IRIS FILIFOLIA}

A strain of Spanish Iris flowering 2 or 3 weeks earlier. Doz. $100 \quad 1000$ Imperator. Deep blue; one of the best for

forcing; large bulbs only............ \$0.60 $\$ 3.75 \quad \$ 32.50$ Wedgewood. Light blue, very early..... $1.75 \quad 13.00 \quad 125.00$

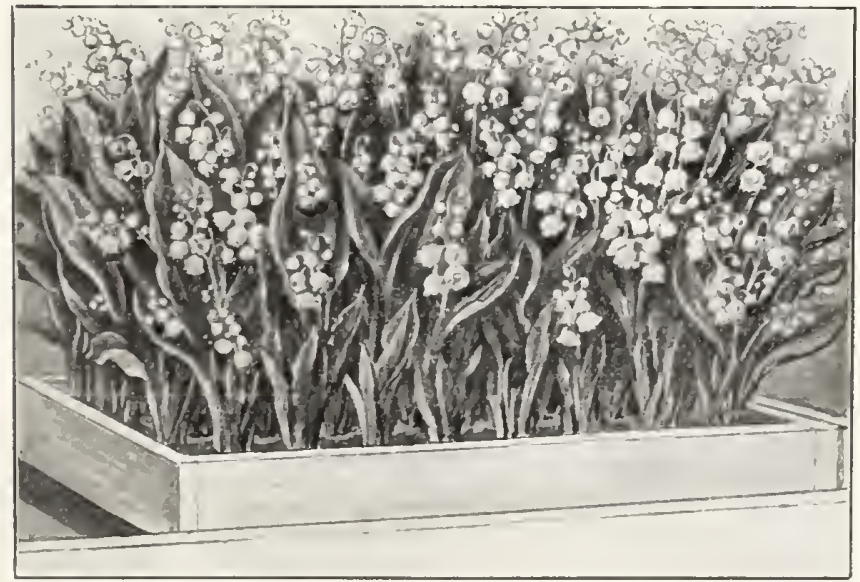

Lily of the Valley

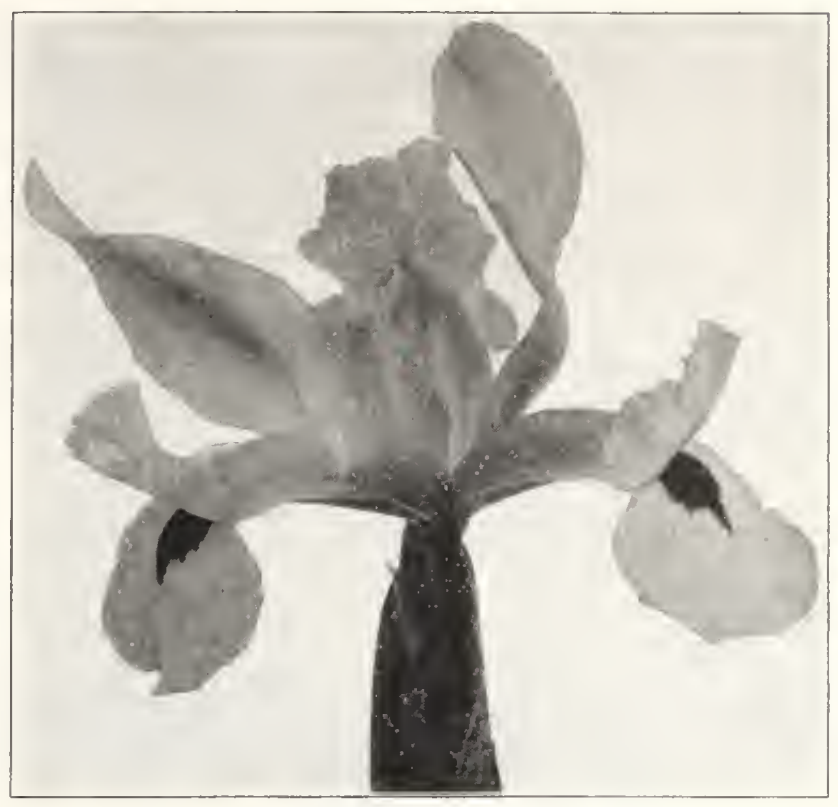

Iris Filifolia, Imperator

\section{DUTCH IRIS (Holiandia}

Best described as a giant strain of very early flowering Iris Hispanica, blooming fully two weeks in advance of the Spanish Iris. Flowers are of enormous size and of remarkable substance.

$\begin{array}{llll}\text { Doz. } & 100 & 1000 \\ \text { A. Bloemard. } & \text { Purplish blue; very early . } \$ 0.70 & \$ 4.25 & \$ 38.50\end{array}$ Adrian Backer. Purplish lilac......... $\quad .80 \quad \begin{array}{r}5.25 \\ 47.50\end{array}$ D. Haring. White tinted lilac; early.......... $.60 \quad 3.75 \quad 32.50$ Leonardo Da Vinci. White and yellow; tall and early . Brilliant blue; extremely

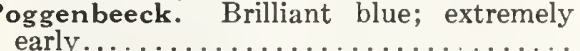

Theresa Schwartze. Standard lilac, falls

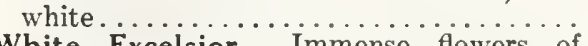

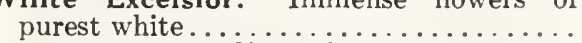
$\begin{array}{lll}80 & 5.25 & 47.50\end{array}$ $\begin{array}{lll}75 & 4.75 & 42.50\end{array}$ $\begin{array}{lll}75 & 4.50 \quad 40.00\end{array}$ $\begin{array}{lll}.75 & 4.50 & 40.00 \\ 65 & 4.00 & 35.00\end{array}$

\section{IXIA}

Scarlet Doz. 100 By P.P. 1000 Extra Fine Mixture............. $\quad .35 \quad 2.50 \quad 2.65 \quad 20.00$

\section{LEUCOJUM VERNUM (Spring Snowflake}

A fine hardy spring flowering bulb with flowers like a Snowdrop, but larger in size. 80c. per doz.; per $100, \$ 5.00 ; \$ 45.00$ per 1000 .

\section{LILY OF THE VALLEY (Ready in December}

Fancy Giant Flowering ( New Crop). Large pips, often producing 15 or more bells to the spike. Prices will be established.

\section{LILY OF THE VALLEY}

Bundles or Clumps (For Outdoor Use Only)

These are excellent for landscape work. Bundles contain 15 good size pips with good root growth, all of which will flower with the proper care; they are especially imported from abroad, the best of the crop being selected for us, carefully packed and can be stored in a cold cellar. These pips should not be compared with native grown stock which usually throw an average of 2 to 3 flowers to the clump; pips are washed clean and packed in peat moss thus making transportation light. We can make shipment of these from November until May. The Japanese Beetle quarantine does not affect the shipment of this stock. 50c. per bdl.; doz. bdls., $\$ 5.00 ; \$ 40.00$ per 100 bdls.

\section{COLD STORAGE LILY OF THE VALLEY GIANT FLOIVERING}

For a number of years we have made a specialty of these and our strains are reputed to be among the finest.

Prices upon application. 


\section{2 MICHELL'S MISCELLANEOUS BULBS AND ROOTS}

\section{MONTBRETIAS (Ready in February)}

Beautiful summer flowering bulbous plants, resembling miniature Gladiolus. Should be planted in masses for the best effect.

We expect to receive a shipment of choice named varieties, list of which, with prices, will be announced later.

\section{ORNITHOGALUM (Star of Bethlehem}

Arabicum. An attractive flowering bulb for either indoor or outdoor culture; petals pure white, streaked light green, with

black flower center. For indoor culture, treat like hyacinths.

$\$ 1.00$ per doz. (by P. P., $\$ 1.10$ ); per $100, \$ 7.00$ (by P. P., $\$ 7.30$ ); $\$ 65.00$ per 1000 .

\section{OXALIS}

If wanted by Parcel Post, add 10c. per 100 for postage.

$\begin{array}{lllll}\text { Grand Duchess. White } & \text { Doz. } & 100 & 1000\end{array}$

“ “ “

“ “ “

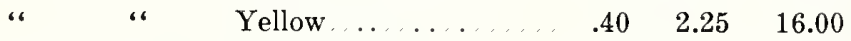

Bermuda Buttercup. Yellow ......... . .45 $2.50 \quad 17.50$

Boweii. Finest pink variety; giant bulbs ... $\quad .50 \quad 3.00 \quad 25.00$

Hirta. Pink. . . . . . . . . . . . . . . . . . $35 \quad 2.00 \quad 15.00$

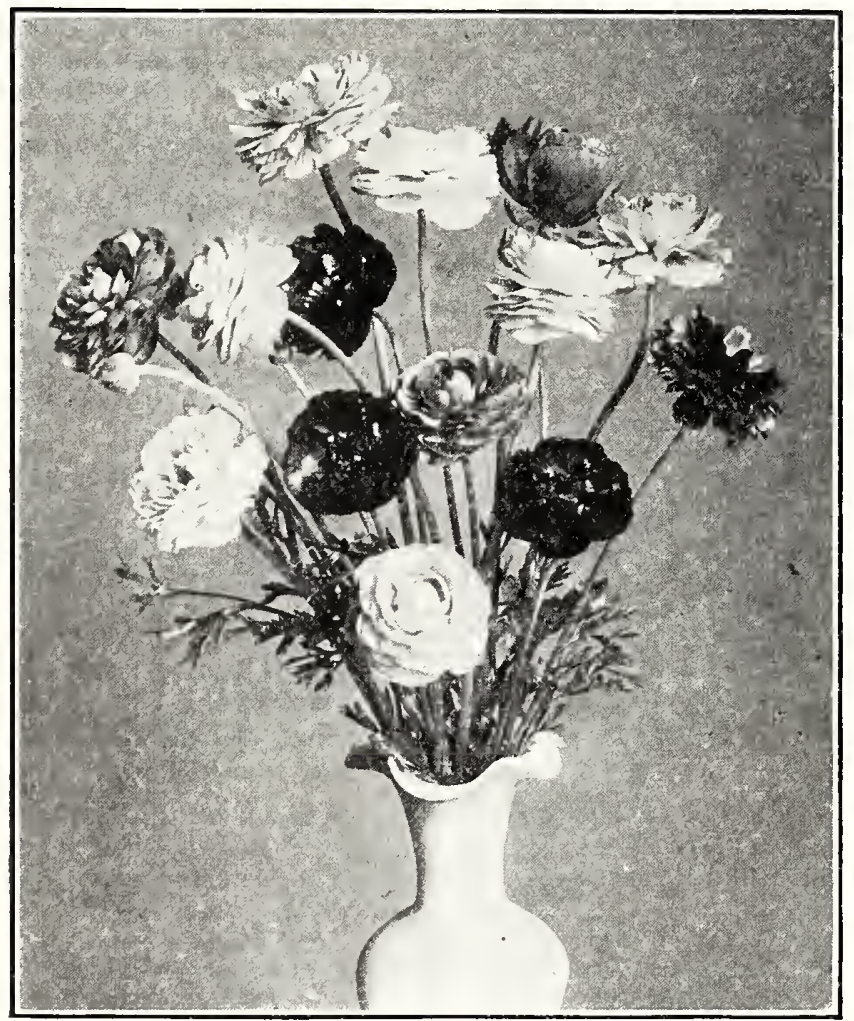

Ranunculus

\section{RANUNCULUS (Buttercups}

Dwarf flowering bulbs, easily grown in pots for Winter bl ooming or in cold frames for Spring.

Palaflor Strain, Choice Mixed. A new strain that produces flowers twice as large and about four times as full as other types. The flowers are in a beautiful range of colors, such as subtle shades and pastel colorings of pinks and yellows and other shades heretofore never produced. $\$ 1.50$ per doz.; per 100 , $\$ 10.50$ (by P. P., $\$ 10.65$ ); $\$ 100.00$ per 1000 .

Giant Fringed Mixed. 45c. per doz.; per 100, $\$ 2.50$ (by P. P., $\$ 2.65) ; \$ 20.00$ per 1000 .

\section{SCILLAS (Squills)}

Excellent for planting around beds of tulips, hyacinths or daffodils. Also do well if planted indoors in pots or pans.

If wanted by Parcel Post, add 15c. per 100 for postage.

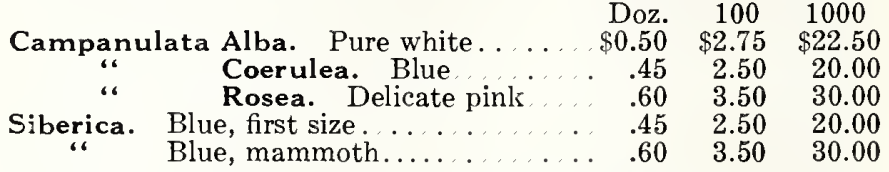

\section{SNOWDROPS (Galanthus)}

Beautiful early flowering bulbs, for edging bulb beds or for planting in masses. $\quad$ Doz. 100 By P.P. 1000 Double. White .............. \$0.70 $\$ 4.00 \quad \$ 4.15 \quad \$ 35.00$ Single. White............ $.50 \quad 3.00 \quad 3.15 \quad 25.00$

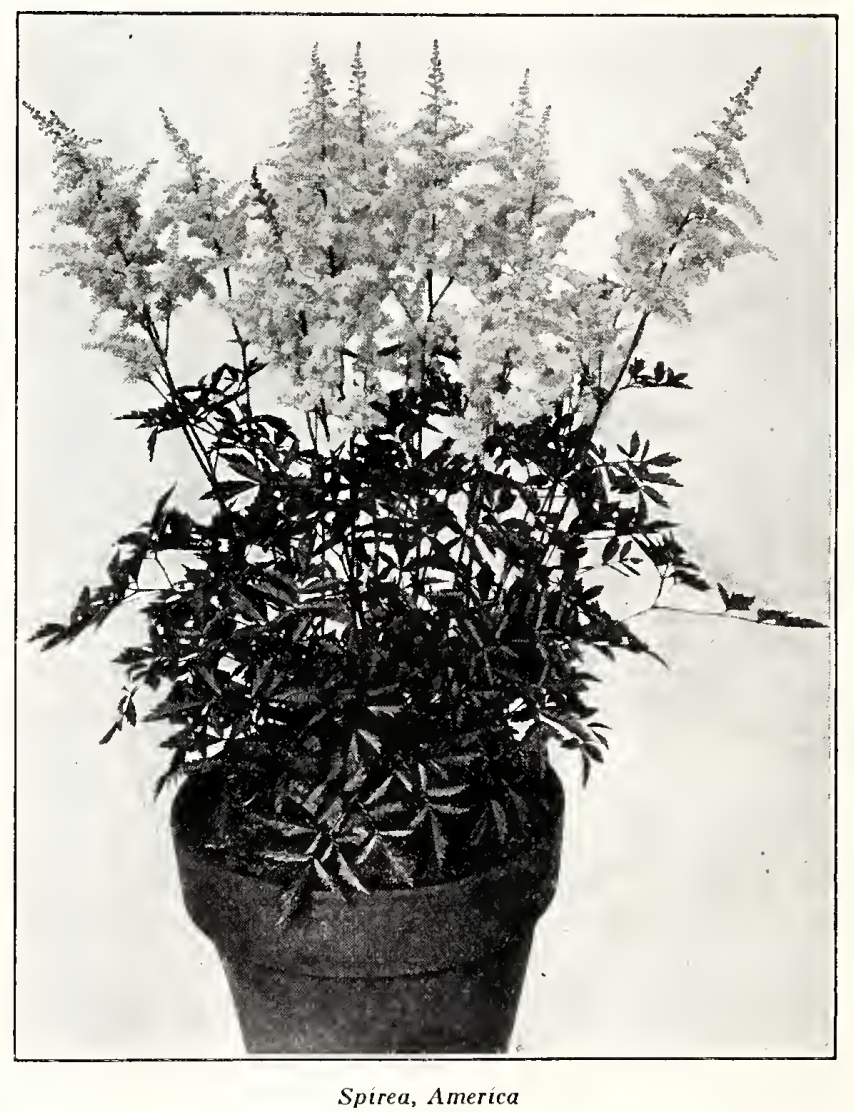

\section{SPIREA (Ready In December)}

Large clumps with plenty of flowering eyes. Doz America. Lilac rose . . . . . . . . . . . . . . . \$ \$4.25

Deutschland. Pure white ........... 5.00

Gladstone. Best white for forcing . . . . . . . 4.25

Gloria. Exquisite rose; excellent for forcing........ 4.25

Peach Blossom. Pale rose; forcing variety...... 4.25

Queen Alexandra. Beautiful pink; Easter variety, 4.25

TRITONIA Doz. 100

100

$\$ 30.00$

37.50

30.00

30.00

30.00

30.00

Crocata. A splendid pot plant, treated like the freesia; also excellent for cutting; large

orange-red flowers ............... \$0.65 $\$ 3.75$

1000

\section{WA TSONIA}

Hybrids. These are for growing in pots or pans and are treated similar to forcing gladiolus ........................ $1.25 \quad 9.00$

85.00

\section{ZEPHYRA NTHES (Fairy Lily}

Dwarf bulbous plants; planted outdoors in May, they will flower the entire season; also well adapted for pot or pan culture.

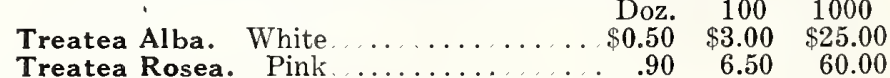


IMPORTA NT-The stock, offered by us, is the best obtainable and will give best satisfaction to the most critical buyer. Hou'ever we cannot guarantee the success of the grower, who purchases the stock, cxcept if the stock turns out not being true to name, and in such casc, our liability is limited to the invoice value at the time of shipment.

We recommend all shipments to go by express, exccpt small shipments, which can readily go by mail.

If shipments arrive in bad condition, accept them and receipt for them accordingly and enter claim to the transportation company. We, of course, will assist you in cvery possible way.

Any complaints as to the quality cannot be entcrtained, unless made to us within two days after receipt of goods.

\section{GERANIUM “MICHELL'S SENSATION”}

(A Cross between Ricard and Jean Viaud.)

Well named, as it is really a "Sensation," and surpasses all red varieties, now in existence.

As a pot plant for Easter Sales or Mothers' Day, or as a bedding plant it has no equal in brilliancy of color, free-flowering and habit of plant. Below are a few of the outstanding features of this sterling novelty.

A-Very vigorous grower.

B-Free-flowering qualities, not known in any other variety.

C-Handsome foliage of leathery substance. Light green with dark zone.

D-Brilliant red, Poinsettia colored. Double flower heads, expanding 5 to 6 inches across.

E-Covered continuously with flower heads, often 6 to 7 at one time.

F-May be had in bloom for Christmas. Most valuable as an Easter plant.

Per 25 Per 100 Per 1000 $2 \%$-in. Pot Size(ready at any time desired) $\$ 4.00 \$ 12.00 \quad \$ 100.00$ Rooted Cutting (ready October and later) $\quad 7.00 \quad 60.00$

\section{NEWER AND STANDARD VARIETIES OF GERANIUM, 21/4 IN. STOCK}

Good stock of Geranium will be scarce, but we have provided a fine stock of well grown $2 \frac{1}{4} \mathrm{in}$. stock for shipment from October to April. No order will be executed for less than 25 plants of any one variety. Order early.

$$
\begin{array}{cc}
21 / 4 \text {-inch } & \text { stock } \\
100 & 1000
\end{array}
$$

Helen Michell. Compact; free-flowering. The old

reliable scarlet. . . . . . . . . . . . . . . . . \$7.00

Alphonse Ricard. Bright vermilion. . . . . 6.50

Beaute Poitevine. Light salmon........... 6.50

Fiat (New). Beautiful pinkish salmon .......... 10.00

Mme. Buchner. Double white . . . . . . . . 6.50

Mme. Landry. Bright salmon............ 6.50

Mrs. Gloede. Deep carmine pink.......... 7.00

Mrs. Lawrence. Salmon pink........... 7.00

Pink Barney. Shrimp pink. . . . . . . . . . 6.50

Irvington Beauty (New). Rose pink.

Radio. Intense scarlet. . . . . .

Salmon Ideal (New) ................

$9.00 \quad 80.00$

Red Barney. Brilliant scarlet

$6.50 \quad 60.00$

$10.00 \quad 90.00$

S. A. Nutt. Dark red.

60.00

$6.00 \quad 55.00$

\section{ASPARA GUS}

\begin{tabular}{|c|c|c|c|}
\hline \multicolumn{4}{|c|}{ Per 25 Per 100 Per 1000} \\
\hline Plumosus & lanus. $2 \frac{1}{4}$-inch pots. & & $\$ 60.00$ \\
\hline Plumosus & anus. 3 -inch pots, extra strong. 3.50 & 12.00 & 110.00 \\
\hline Sprengeri. & $21 / 4$-inch pots......... & 7.00 & 60.00 \\
\hline Sprengeri. & 3 -inch pots..... & 12.00 & 110.00 \\
\hline
\end{tabular}

HENRY F. MIC HELL CO.

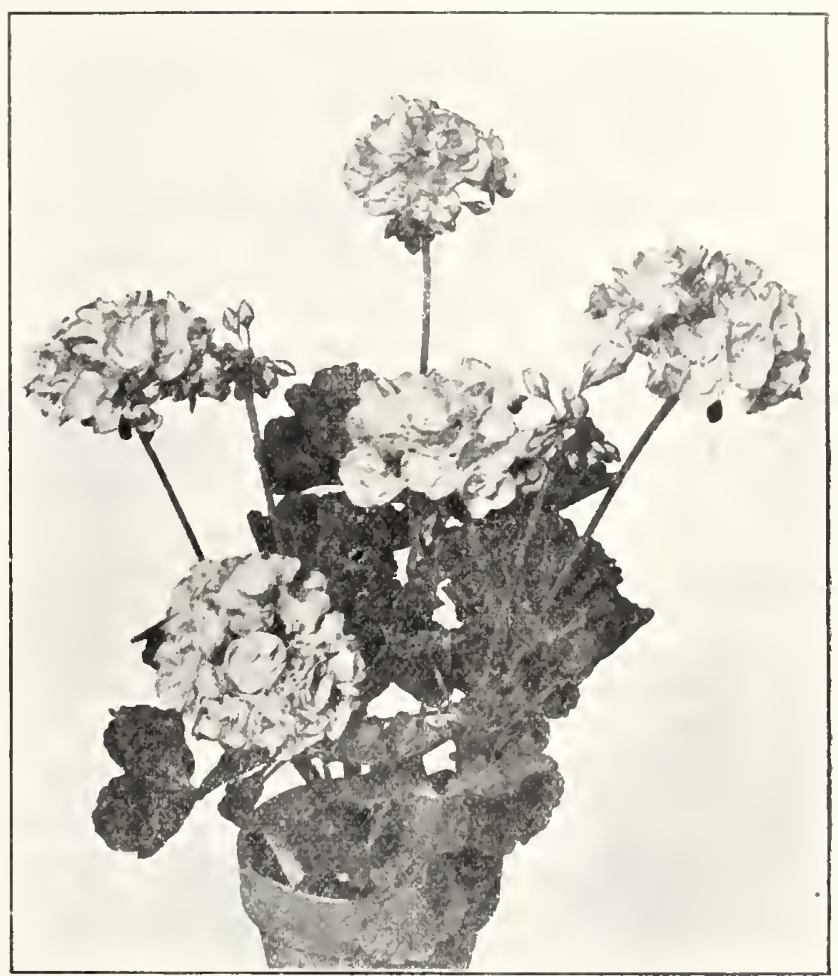

Geranium "Michell's Sensation"

\section{BEGONIA $\left(2 \frac{1}{4}\right.$ in. Pots $)$}

Per 25 Per 100 Per 1000

Albert Martin. Dark carmine .......... $\$ 2.00 \quad \$ 6.50 \quad \$ 55.00$

Alba perfecta grandiflora. Pure white.. 2.50 $8.00 \quad 75.00$

Feasti or Beefsteak.................... $3.00 \quad 11.00 \quad 100.00$

Luminosa. Deep red................ $2.00 \quad 6.50 \quad 55.00$

Primadonna. Rose shaded carmine.... 2.00 $6.50 \quad 55.00$

M. D. Lesseps. Foliage silvery spotted,

flowers pink and white...... 2.50

Mrs. Townsend. Broad foliage: pink flowers $2.50 \quad 9.00 \quad 80.00$

Salmon Queen. Salmon pink............ $2.00 \quad 6.50 \quad 55.00$

X-Mas Cheer. Crimson-scarlet.......... 2.00 6.50 55.00

Rex. A fine assortment of many varieties... $4.50 \quad 15.00 \quad 140.00$

\section{CALCEOLARIAS (21/4in. Pots) (Fall Delivery)}

For Easter and Mothers' Day there is no potted plant that will equal the Calceolaria.

Amber King. Amber-colored.

Bronze Queen (Shrubby Type). Beautiful orange... $8.00 \quad 25.00$

Pink Beauty. Rose pink................. $8.00 \quad 25.00$

Eureka Compacta Jamesoni. Half-dwarf in beautiful colors as Maroon, Cerise, Apricot, etc. .

Hybrida grandiflora (Kelway's strain).

Stewartii. Canary yellow.

$8.00 \quad 25.00$

Lymanni. Cinnamon-red ................ $8.00 \quad 25.00$

Hybrida Compacta. Dwarf; including all the best

colors ........................ 4.00

14.00 


\section{CINERARIA $\left(2 \frac{1}{4}\right.$ in. Pots $)$}

Ready from September to November. mixed . . . . \$7.00 \$65.00 Multifora Nana (Potsdam Strain) ............. $7.00 \quad 65.00$ Cremer's Prize Strain. Cross of Multiflora com-

pacta, grandiflora Hybrida and stellata. Won

first prize at all Flower shows. . . . . . . . . . . . $11.00 \quad 100.00$

\section{CYCLAMEN PLANTS}

Grown from our Giant Show Strain of seed, which is grown for us by Specialists and cannot be excelled for the large size and beautiful coloring of the flowers. In separate colors, Perle of Zehlendorf, Blood Red, Bright Red and Rose Pink. 3-inch pot plants, $\$ 3.00$ per doz.; $\$ 20.00$ per $100 ; \$ 180.00$ per 1000 . 4 -inch, $\$ 5.50$ per doz.; per $100, \$ 40.00 ; 4$-inch extra heavy, $\$ 6.25$ per doz.; per $100, \$ 45.00$.

See Page 23 for Cyclamen Seed

\section{CRASSULA}

(Jade Plant or Chinese Rubber Plants)

We have a fine stock of these, which are now very popular in making up indoor gardens.

Arborescens. $2 \frac{1}{4}$ in..

Per 100 Per 1000

$\$ 12.00 \$ 100.00$

3 in. (extra heavy)......... $35.00 \quad 320.00$

\section{DAISIES (For Cutting)}

Unexcelled for cut flowers; flowers keep well after being cut. We offer extra fine stock in $2 \frac{1}{4}$-inch stock.

Boston Yellow. 21/4-inch Giant White or Mothers Favorite. $2 \frac{1}{4} /$-inch..... $7.50 \quad 65.00$

DRA CAENA

Massangueana. Excellent house plants.

4-inch pots.

Doz. 100 $\$ 12.00 \$ 90.00$

\section{DRACAENA INDIVISA}

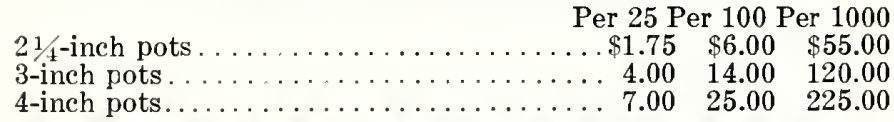

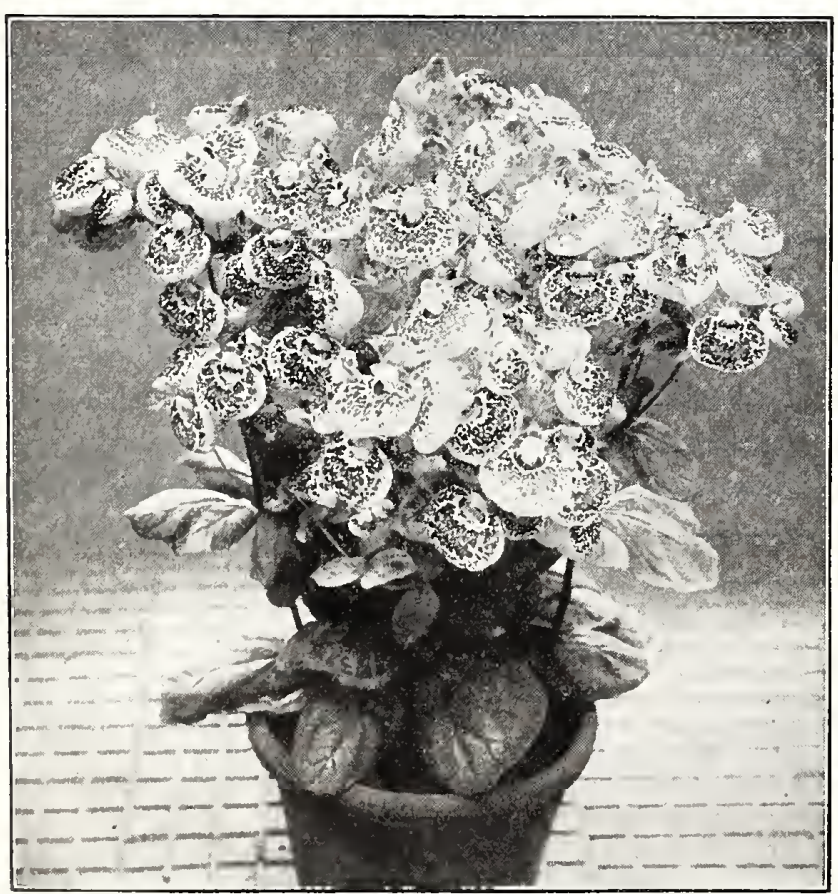

Michell's Grandifora Calceolaria

\section{EPIPHYLLUM TRUNCATUM \\ OR XMAS CACTUS}

Splendid for Japanese Gardens or indoor Rockeries.

Per 25 Per 100

$21 / 4$-inch pots . . . . . . . . . . . . . $\$ 3.00$ \$11.00

3 -inch pots........................ ${ }_{20.00}$

\section{ERLANGEA TOMENTOSA}

Ageratum-blue; fine for Winter cutflowers. Price for $2 \frac{1}{4}$-inch pot plants. $\$ 7.00$ per 100 ; per $1000, \$ 65.00$.

\section{EUPHORBIA JACQUINIFLORA}

One of the finest and most useful plants for mid-winter flowering. The lovely orange scarlet flowers are produced on long, graceful sprays, that are adapted for any decoration. 21/4-inch pot plants, per $25, \$ 4.50 ; \$ 15.00$ per 100 ; per $1000, \$ 140.00$.

\section{FERNS $(21 / 4$ inch Stock $)$}

Although usually for delivery from May to July, we have made arrangements to supply stock throughout the year. Extra fine clean stock.

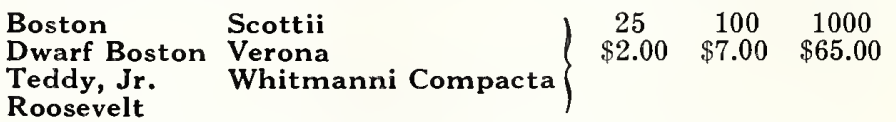

Not less than 25 of any one variety sold.

\section{FERNS (4 Inch Stock)}

\begin{tabular}{|c|c|c|c|}
\hline & $\operatorname{Re}$ & & \\
\hline $\begin{array}{l}\text { Boston } \\
\text { Dwarf Boston } \\
\text { Teddy, Jr. }\end{array}$ & $\begin{array}{l}\text { Scottii } \\
\text { Verona } \\
\text { Whitmanni }\end{array}$ & $\begin{array}{c}25 \\
\$ 12.50\end{array}$ & $\begin{array}{l}100 \\
\$ 40.00\end{array}$ \\
\hline
\end{tabular}

Not less than 25 of any one variety sold.

\section{FERNS (6 Inch Stock)}

\section{Ready now}

These plants are all pot-grown and are not to be compared with the unshapely plants sometimes grown in benches. Prices are for strong plants from 6 -inch pots.

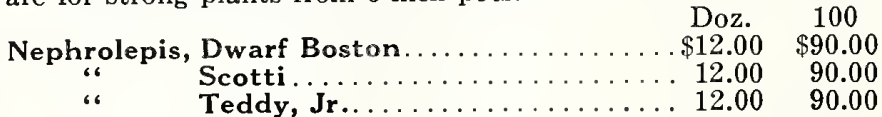

\section{TABLE FERN SEEDLINGS}

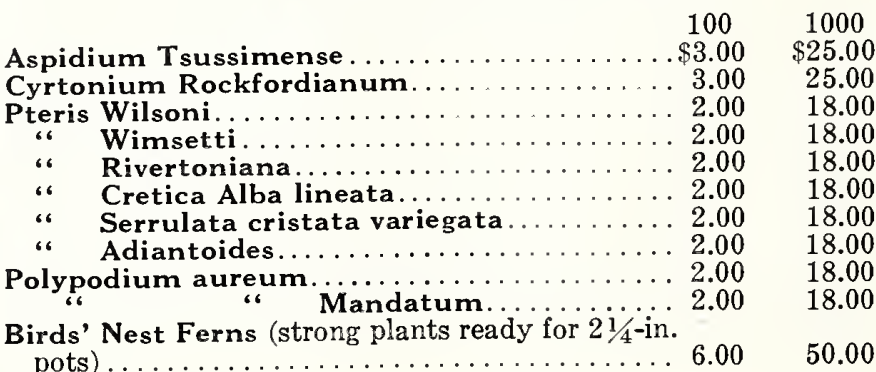

\section{TESTIMONIAL ON MICHELL'S CYCLAMEN}

Oct. 15 th, 1930.

We are more than pleased with the Cyclamens, which we received from you. The same produced the most wonderful plants and from now on will only grow your strain. Hanover Floral Co., Inc.

Hanover, N. J. 


\section{MICHELL'S CHOICE PLANTS FOR FLORISTS}

No order filled for less than 25 plants of any one variety, except where noted.

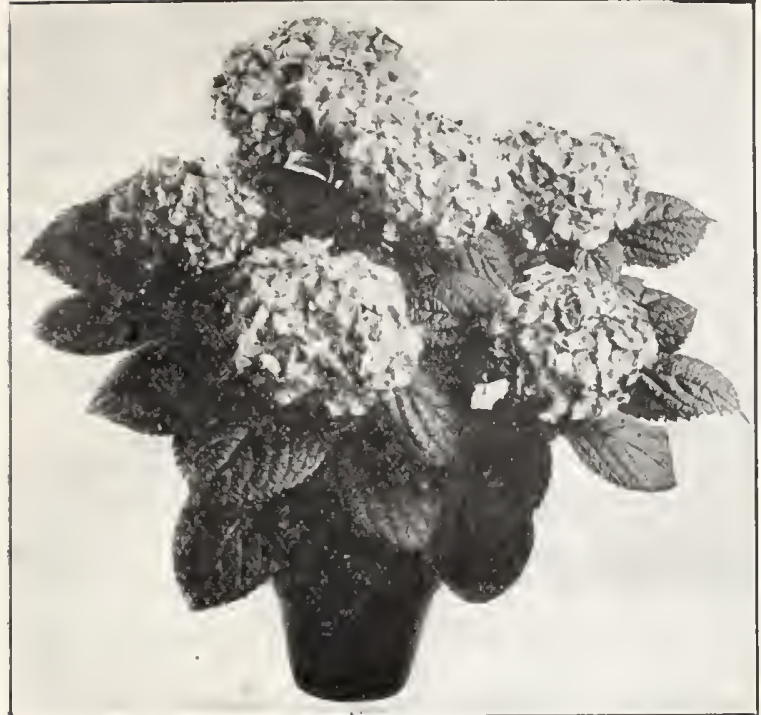

Hydrangea "Goliath"

\section{GERA NIUM}

(See Page 13)

\section{GERBERA JAMESONI (Transvaai Daisy)}

We offer these in extra strong two-year divisions. Wonderful assortment of colors.
Jersey Beauty. Dark pink

Ruby Queen. Crimson.

Salmon Beauty. Salmon red

Storm King. Pure white. . .

Sulphurea. Yellow.

Mixed Hybrids. All colors
Per doz. Per 25 Per 100 $\$ 8.50 \quad \$ 15.00 \quad \$ 50.00$ $8.50 \quad 15.00 \quad 50.00$ $8.50 \quad 15.00 \quad 50.00$ $\begin{array}{lll}8.50 & 15.00 & 50.00\end{array}$ $\begin{array}{lll}6.50 & 12.00 & 40.00\end{array}$ $\begin{array}{lll}8.50 & 15.00 & 50.00\end{array}$

\section{MYOSOTIS, MICHELL'S GIANT}

\section{WINTER-FLOWERING FORGET-ME-NOTS}

The finest Winter-flowering Myosotis in the market, producing large flowers of deep blue color. Plant in September for flowering from November and all through the winter.

Strong $21 / 4$-inch plants: Per $25, \$ 3.00 ; \$ 10.00$ per 100 ; per $1000, \$ 80.00$.

\section{PANDANUS}

Veitchi. We have an excellent stock of good heavy plants in 6 -inch pots, well colored, at $\$ 1.50$ each.

\section{PRIMULAS}

We offer the very best monster strain of Primula Obconica, also Primula Malacoides and Chinensis in the largest and best types. Write for a list of varieties and prices.

\section{SAINTPA ULIA IONANTHA (African Vioiet)}

We offer fine strong $21 / 4$-inch pots of this desirable variety. Price: Per 25 plants, $\$ 7.50 ; \$ 25.00$ per 100

\section{SANSEVIERIA ZEYLANICA LAURENTII}

Extra heavy, well colored, 6-inch pot plants, $\$ 1.50$ each.

\section{SMILAX}

Per 100 Per 1000

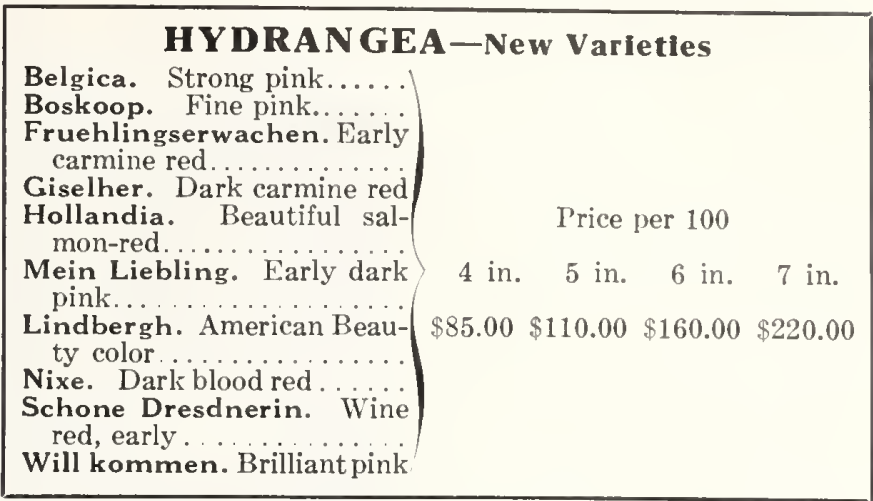

\section{H Y D RA N GEAS \\ Standard and Newer Varieties Price per 100} Deutschland. Salmon pink ....\$45.00 \$65.00 $\$ 85.00 \$ 110.00$ Juliana. Peach pink and white... $45.00 \quad 65.00 \quad 85.00 \quad 110.00$ Koenigin Wilhelmina. Rose... $45.00 \quad 65.00 \quad 85.00 \quad 110.00$ La France. Good for blueing. . . . 45.00 $455.00 \quad 85.00 \quad 110.00$ Mignon. Pink............ $45.00 \quad 65.00 \quad 85.00 \quad 110.00$ Paris. Good for steel blue coloring. $45.00 \quad 65.00 \quad 85.00 \quad 110.00$ Freya. Glossy carmine......... $35.00 \quad 55.00 \quad 75.00 \quad 90.00$ Gertrude Glahn. Dark rose... $35.00 \quad 55.00 \quad 75.00 \quad 90.00$ Goliath. Truly a giant........ $35.00 \quad 55.00 \quad 75.00 \quad 90.00$ Niedersachsen. Good for steel blueing ................ $35.00 \quad 55.00 \quad 75.00 \quad 90.00$ Odin. Deep carmine......... $35.00 \quad 55.00 \quad 75.00 \quad 90.00$ Gudron. Clear pink.......... $35.00 \quad 55.00 \quad 75.00 \quad 90.00$ Helge. Soft red............ $35.00 \quad 55.00 \quad 75.00 \quad 90.00$ Marechal Foch. Deep carmine... $35.00 \quad 55.00 \quad 75.00 \quad 90.00$ Parsifal. Red fringed petals .... $35.00 \quad 55.00 \quad 75.00 \quad 90.00$ Lorelei. Carmine red......... $32.50 \quad 45.00 \quad 65.00 \quad 80.00$ Rheingold. Brilliant pink..... $32.50 \quad 45.00 \quad 65.00 \quad 80.00$ Splendens. Clear red.......... $32.50 \quad 45.00 \quad 65.00 \quad 80.00$ Trophee. Early red........... $32.50 \quad 45.00 \quad 65.00 \quad 80.00$ Chautard. Pink............ $32.50 \quad 45.00 \quad 65.00 \quad 80.00$ E. G. Hill. Clear pink....... $32.50 \quad 45.00 \quad 65.00 \quad 80.00$ G. Moulliere. White ......... $32.50 \quad 45.00 \quad 65.00 \quad 80.00$ Otaksa. The old reliable ...... $32.50 \quad 45.00 \quad 65.00 \quad 80.00$

\section{PELARGONI UMS $\left(2^{1 / 4}\right.$ inch Pots $)$}

Extra fine, healthy plants; no white fly.

No orders filled for less than 25 plants of any variety.

Edith North (New). Rose pink, shaded

Per 25 Per 100 Per 1000 deeper in upper petals, blotched dark

brown.................... \$3.00 \$11.00

$\$ 95.00$

Gardeners Joy. Apple blossom, upper petals brown... A. Cattleya blue; crimson

German Glory. Cattleya blue; crimson

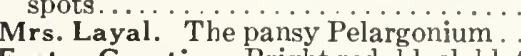

Easter Greeting. Bright red, black blotch 3.00

Lucy Becker. Rosy pink.......... 3.00

Swabian Maid. Brilliant salmon ...... 3.00

Wurtembergia. Deep red.......

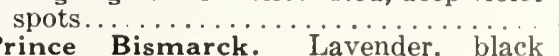

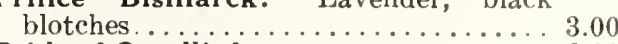

Pride of Quedlinburg. . . . . . . . . . .

Springtime $(N e w)$. Beautiful white and

pink ruffled ................. 4.00

11.00

95.00

11.00

11.00

11.00

11.00

11.00

11.00

11.00

11.00

11.00

14.00

95.00

95.00

95.00

95.00

95.00

95.00

95.00

95.00

95.00

125.00

\section{TESTIMONIAL}

January 28, 1931.

We wish to express our appreciation for the fine plants of Geranium "Michell's New Sensation" you have sent to us. They proved all you claimed them to be. American Fork, Utah 


\section{STEVIA}

Double True Half Dwarf. Best for greenhouse forcing. 21/4inch pots, $\$ 6.00$ per 100 ; per $1000, \$ 50.00$.

\section{VINCA VARIEGATA}

We offer, an extra fine quality of these indispensable florist's plants; extra heavy stock, well variegated.

Clumps. Extra large, field grown (ready October). $\$ 8.00 \quad \$ 75.00$

Layer Plants (ready October) . . . . . . . . 2.50 20.00

$21 / 4$-inch pots ready from January on ........ $6.00 \quad \mathbf{5 5 . 0 0}$

3 -inch pots. . S ready from January on......... 13.50

\section{SNAPDRAGON (Antirrhinum $2 \frac{1}{4}$ inch Stock)}

Per 25 Per 100 Per 1000

Afterglow. New bronze.............\$2.00 $\$ 7.00 \quad \$ 65.00$

Cheviot Maid. Clear pink ........... 2.00 $7.00 \quad 65.00$

Ceylon Court. Canary yellow.......... $1.75 \quad 6.50 \quad 60.00$

Chapman's Pink................. $1.75 \quad 6.50 \quad 60.00$

Chapman's Yellow............... $1.75 \quad 6.50 \quad 60.00$

Geneva. Rose pink................ $1.75 \quad 6.50 \quad 60.00$

Golden Pink Queen................ $1.75 \quad 6.50 \quad 60.00$

Happiness (New). Clear pink.........2.00 $7.00 \quad 65.00$

Helen. Delicate salmon............. $1.75 \quad 6.50 \quad 60.00$

Indian Summer. Copper colored....... $1.75 \quad 6.50 \quad 60.00$

Keystone. Pink ................ $1.75 \quad 6.50 \quad 60.00$

Orlando. Lovely bronze............ $1.75 \quad 6.50 \quad 60.00$

Philadelphia Pink............... $1.75 \quad 6.50 \quad 60.00$

Roman Gold. Combination of pink, copper

and yellow..................... $1.75 \quad 6.50 \quad 60.00$

Rose Queen $(N e w)$. Real rose.......... $1.75 \quad 6.50 \quad 60.00$

Sunburst Improved. Yellow .......... $1.75 \quad 6.50 \quad 60.00$

White Rock................... $1.75 \quad 6.50 \quad 60.00$

\section{PANSY SEEDLINGS}

Produced from Michell's Giant Exhibition strain of seed in choicest mixture of colors. 75c. per $100 ; \$ 2.75$ for $500 ; \$ 5.00$ per 1000 .

\section{MYOSOTIS SEEDLINGS}

Splendid stock of Alpestris Victoria variety. 75c. per 100; $\$ 2.75$ for $500 ; \$ 5.00$ per 1000 .

\section{DAISY OR BELLIS PERENNIS SEEDLINGS}

In Monstrosa or Giant flowering type.

White and Pink, each separate. 75c. per $100 ; \$ 2.75$ for 500 ; $\$ 5.00$ per 1000 .

NOT LESS THAN 100 SEEDLINGS OF A KIND SOLD

These travel best by Parcel Post. Add 20c. per 100 for postage.

PLEASE NOTE.-Shipments of perishable goods can only be made at your risk.

If shipments arrive in bad condition, accept them and receipt for them accordingly and make claim for your loss on the transportation company. We, of course, hold ourselves ready to assist you in any possible way. It has been found that claims can be collected more readily by the person receiving the goods than by the shipper.

\section{AZALEA INDICA \\ OWN ROOT STOCK}

This type of Azaleas is especially adapted for basket work and has been successfully grown by a large number of progressive florists. Some varieties are most suitable for pots and will give wonderful plants for Easter. Cultural directions will be mailed with each order. While they should not be confused with the grafted stock, formerly imported from Belgium, they are most appropriate Easter plants and have a great decorative value. We offer the same in the following varieties, ready in October. Varieties marked (P) are especially suitable for pot plants.

(P) Pink Beauty. Large flowering, compact grower; flowers light pink.

George Franke. Early, large flowering, low growing sorts; to be used for basket work; salmon pink with red throat.

(P) Salmon Queen. Early tall growing variety. Free bloomer; rich salmon pink.

(P) Illuminator. Early flame colored with slightly purple throat. Compact grower.

(P) Coraline. A beautiful coral color with small flowers and foliage. Dwarf, compact grower.

Prince of Orange. Orange red, large flowers, free bloomer.

(P) Pride of Dorkin. A beautiful cerise.

(P) Pink Pearl. A beautiful light pearl pink. Very compact grower.

Salmon Beauty. A late blooming salmon; large flowering. A splendid variety.

(P) Coccinea. A dark satiny red; one of the best varieties for Easter.

(P) Harry Deitch. A heavy frilled rose pink; large flowers; compact grower; very desirable.

Ivereana. A variegated pink and white; a good strong grower.

Formosa. The hardiest and strongest grower of all. Color deep lavender to purple. Either for pots or landscape use.

(P) Rose Queen. A strong very compact grower. Very late blooming. A beautiful frilled rose pink.

Mrs. Arthur Freed. A late blooming white striped with pink.

(P) Blushing Bride. A delicate light pink; very large flower.

(P) Albert Elizabeth. The most beautiful of all white, margined with red.

(P) Xmas Star. A dark single red; one of the earliest; strong grower.

(P) Madame Moreau. Very heavily frilled variegated pink and white; similar in color to Vervenaena.

(P) Hexe. Dark red; strong compact grower.

Firefly. Deep red; tall growing; fine for landscaping.

(P) Kurume Hinomaya. One of the best Japanese types. Very free bloomer.

Hinodegiri. Bright red; compact grower. Good for forcing and landscape work.

Price of above Azaleas

Each Dozen

$10-12$-inch heads.................. \$1.10 \$12.00

$12-15$-inch heads. . . . . . . . . . . . . $1.75 \quad 20.00$

$15-18$-inch heads.................... $2.75 \quad 30.00$ 
Prices quoted are for extra strong one-year-old field roots, not Seedlings. Not less than 25 of any one variety at 100 rate. No Order accepted for less than 10 of any variety, except where noted.

An investment ill Perennials is most profitable. We send out strong field grown plants, which will give splendid results the first season. Perennials bloom at a time of year when greenhouse cut flowers are scarce. Grow your own supply.

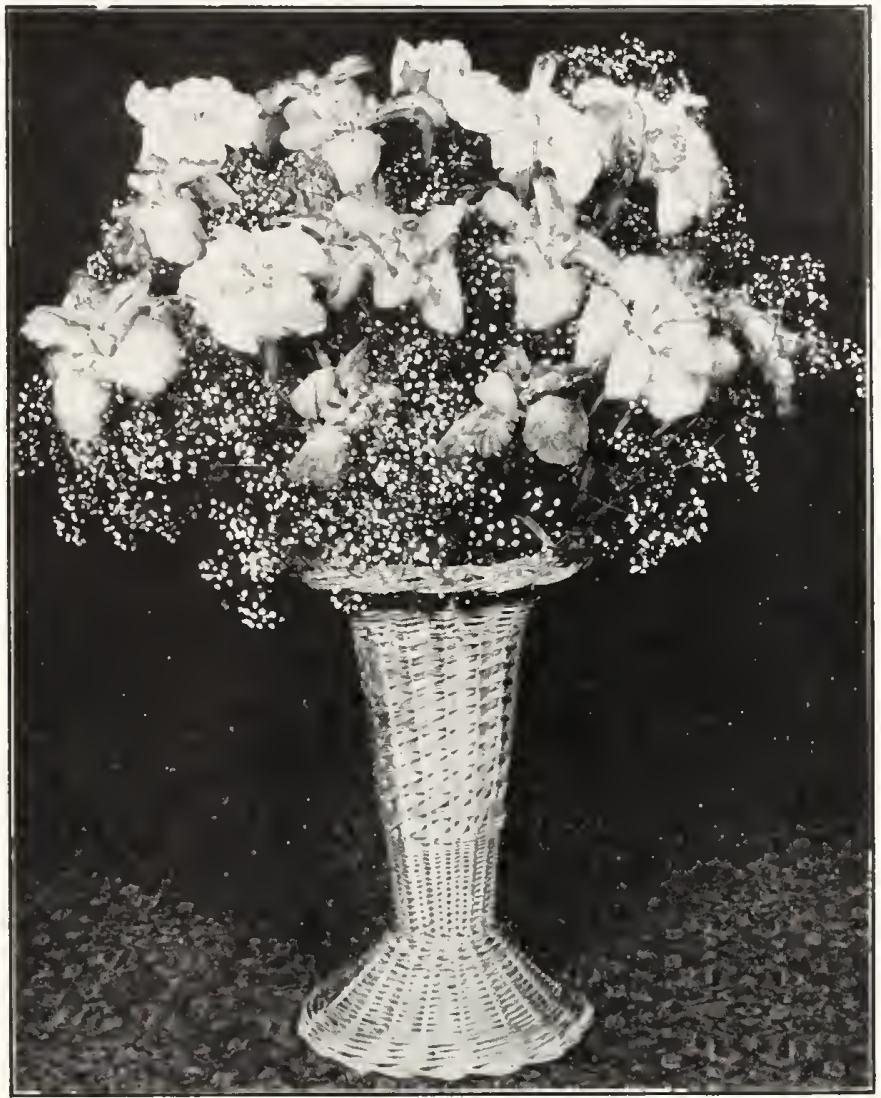

IMPORTANT FOR FLORISTS
The plants, we send out, must measure up to a high standard. We are constantly experimenting with new varieties and discarding others. The following list represents only field grown hardy plants of worthy varieties.

As time goes on, there are more forists realizing the fact that the use of perennials is an important factor in their business throughout the dull summer months.

Within the past few years many florists have made plantings of perennials in some vacant land adjoining or close to their greenhouses. They are finding it more important every year to be able to cut outdoor flowers while they are changing soil and preparing their houses for their usual run of greenhouse stock.

We are advised by many leading florists, who have made a practice of this, that the benefits derived from a perennial planting are beyond explanation by mere words. While the greenhouse is idle, perennials fill the gap in the way of supplying fresh flowers which are suitable for general florists use, and thus prevents them from ordering flowers from distant wholesale markets. They are able at all times to cut fresh flowers for their special work throughout the months of July, August and September, when there is practically no greenhouse flowers to be had. An investment in perennials is indispensable and pays returns each year that are many times larger than the original amount invested.

Our perennials are grown especially for florists use. The best of the plants are supplied. We are always striving to furnish the best plants in the several varieties that we offer suitable for cutting purposes. We are glad to recommend special lists which cover a long period of bloom out of doors. By having a collection of the cut flower perennials you need not worry as to where you are going to secure flowers for a job which must be completed in a limited time.

(R) Achillea Argenteum. Yellow.

*-Boule de neige. Double white.

*-Filipendula. Yellow.

-Millefolium Roseum. Pink

*-Perry's White. White.

* - The Pearl. Pure white

(R)-Tomentosa. Yellow

Aconitum Bicolor. White and blue

-Fischeri. Pale blue.

- Sparks Variety. Deep blue

Wilsoni. Mauve...

Agrostemma Atrosanguinea. Deep red

*-Walkerii. Brilliant rose.

(R) Alyssum Argenteum. Yellow

(R)-Rostratum. Pale yellow.

R)-Saxatile compactum. Golden

Anchusa I talica Dropmore. Blue

(R)-Myosotidiflora. Blue

Opal. Pale blue.

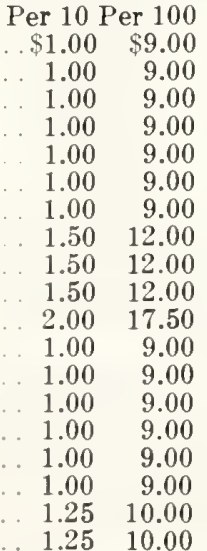

Anemone Giant Blanche. Double white.

- Mount Rose. Double pink.

-Vitifolia Hupehensis. Single pink

-Sylvestris. White.

Aquilegia alpina. Dark blue

(R) - Canadensis. Red and yellow

- Chrysantha. Golden yellow.

-Dobbie's Imperial Hybrids. New strain.

*-Martins Superb Pink. The best pink

-Mrs. Scott Elliotts' Hybrids. Mixed

- Nivea grandiflora. Pure white.

- Long spurred Hybrids. Mixed

(R) Arabis alpina. Pure white

(R) - Nana compacta. Very dwarf; white.

(R) Arenaria grandiflora. Pure white

(R)-Montana. White.

(R)-Verna. Mossy like; white

(R) - Verna caespitosa. White

(R) Armeria Formosa. Light pink
Per 10 Per 100

$\$ 1.50 \$ 12.00$

$1.50 \quad 12.00$

$1.50 \quad 12.00$

$1.50 \quad 12.00$

$\begin{array}{ll}1.00 & 9.00\end{array}$

$1.00 \quad 9.00$

$\begin{array}{ll}1.00 & 9.00\end{array}$

$1.25 \quad 10.00$

$1.50 \quad 12.00$

$1.50 \quad 12.00$

$.00 \quad 9.00$

$1.00 \quad 9.00$

$1.00 \quad 9.00$

$1.00 \quad 9.00$

$\begin{array}{ll}1.00 & 9.00\end{array}$

$1.00 \quad 9.00$

$1.00 \quad 9.00$

$\begin{array}{ll}1.00 & 9.00\end{array}$

$\begin{array}{ll}1.00 & 9.00\end{array}$

Varieties marked (*) are especially suitable for cutting, while varieties marked $(\mathrm{R})$ are indispensable for rockeries (wh) 
Per 10 Per 100

(R) Armeria Laucheana. Deep pink.........\$1.50 \$12.00

* Asclepias Tuberosa. Orange-scarlet........... $1.25 \quad 10.00$

* Aster Abendroethe. Rosy red ............. $1.00 \quad 9.00$

*-Beauty of Colwall. Double lavender ....... $1.00 \quad 9.00$

*_Climax. Lavender blue . . . . . . . . . . . . . $1.00 \quad 9.00$

*-Climax White. . .

* Elta. Pale lilac................. 1.00

* Feltham Blue. Aniline blue............. 1.00

* - Highland Morn. Delicate blue . . . . . . . 1.00

*-Maggie Perry. Soft mauve.............. 1.00

*-Mons. Reddish violet. ................ 1.00

*-Novae Anglia Ypres. Rosy red.......... 1.00

*_Perry's Blue........................ 1.00

*_Queen Mary. Dark blue (New) ............. 1.25

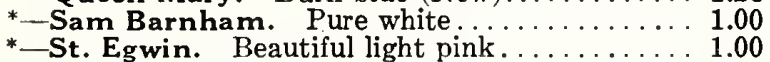

\section{DWARF ALPINE ASTERS}

Acris. Lavender pink.

Excellent for Rockeries

Per 10 Per 100

Alpinus Magnificus. White............... $1.25 \quad 10.00$

Subcoeruleus. Bluish violet.............. $1.25 \quad 10.00$

\begin{tabular}{lll}
\hline R) Aubrietia Bridesmaid. Blush white....... $\$ 1.50$ & $\$ 12.00$
\end{tabular}

(R) -Crimson King. Rich crimson........... $1.50 \quad 12.00$

(R) - Graeca. Violet................... $1.50 \quad 12.00$

Boltonia Latisquama. Lavender pink.......... $1.00 \quad 9.00$

* Buphtalmum cordifolium. Orange yellow.. $1.50 \quad 10.00$

(R) Calamintha Alpina. Blue ............ $1.25 \quad 10.00$

Campanula calycanthema. Blue........... $1.00 \quad 9.00$

- - Pink..................... 1.00

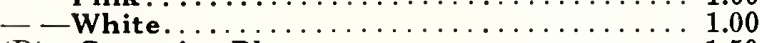

(R)-Carpatica Blue..............

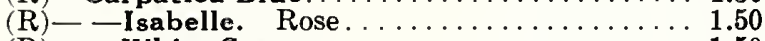

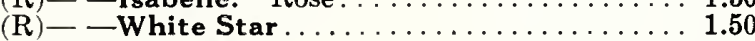

-Medium Blue..................... 1.00

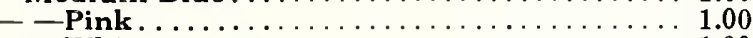

- White..................... 1.00

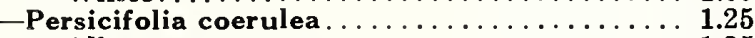

- Alba......................... 1.25

-Rotundifolia.

- Lavender Queen

1.25

1.50

* Carnations Giant Pink

$1.25 \quad 10.00$

$1.25 \quad 10.00$

*-Grenadin Red..................... 1.25

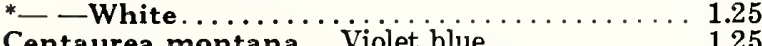

(R) Cheiranthus Allioni. Fiery orange...............

Chelone Barbatus Torreyi. Scarlet............ 1.00

* Coreopsis Lanceola ta Grandiflora. Yellow. . . . . 1.00

(R) Crucianella Stylosa. Bright purple....... 1.00

* Delphinium Belladonna. 1 year old........ 1.00

* - . 2 year old . . . . . . . ............... 1.25

* Bellamosum. 1 year old . . . . . . . . . 1.00

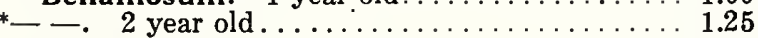

*-Chinensis Blue. . . . . . . . . . . . . . 1.00

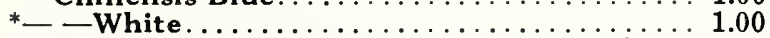

*-Blackmore \& Langdon Hybrids. 1 year old . . 1.25

10.00

*_. - - - 2 year old . . ............. $1.50 \quad 12.00$

\section{DIA NTHUS PRINCE BISMARK}

A most desirable novelty. Grows 12 in. high, flowers all summer; absolutely hardy. The large Rosy pink, sweet scented flowers are excellent for cutting. $\$ 1.50$ for 10 ; per $100, \$ 12.00$.

Dianthus Arenarius. White, carmine ring......\$1.25 $\$ 10.00$

*-Alwoodi Alpinus. New hybrid........... $1.25 \quad 10.00$

- Her Majesty. Pure white............... 1.5012 .00

*-Atroccineus FI. PI. Scarlet . ... $\quad 1.00 \quad 9.00$

*-Plumarius Cyclops. Red hybrids. . . . . . . . $1.25 \quad 10.00$

*_-Mrs. Simkins. Pure white............ $1.25 \quad 10.00$

*_Plumarius Semperflorens. Mixed .......... $1.00 \quad \mathbf{9 . 0 0}$

* Dianthus Barbatus White Beauty......... $1.00 \quad 9.00$

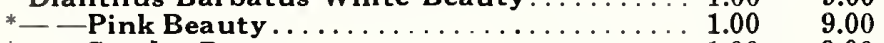

* - Scarlet Beauty.................. $1.00 \quad 9.00$

-Mrs. Simkins. Pure white; clove scented... $1.25 \quad 10.00$

Dielythra Spectabilis (Bleeding Heart; Dicentra). Heart shaped red flowers; excellent for forcing. $\$ 3.50$ per 10 ; per 100 , $\$ 30.00$.

\section{CHRYSANTHEMUM MAXIMUM}

(Shasta Daisy)

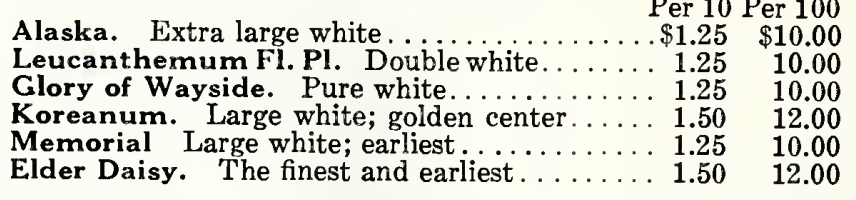

Per 10 Per 100

Dictamnus Fraxinella Alba. White........\$2.00 $\$ 17.50$

- -Rubra. Red..................2.00 17.50

Digitalis Giant Shirley. Mixed ........... $1.00 \quad \mathbf{9 . 0 0}$

*_Monstrosa mixed. Large flowering . . . . . . . 1.00 9.00

—Gloxinioides Alba. White . . . . . . . . . . $1.00 \quad 9.00$

- -Rubra. Rose................. $1.00 \quad 9.00$

- - Purpurea. Purple............... $1.00 \quad \mathbf{9 . 0 0}$

*Lutzii Hybrids. New; salmon colored . . . . . $1.25 \quad 10.00$

*Doronicum Excelsum. Yellow .............. $1.75 \quad 15.00$

*Echinops Ritro. Metallic blue, thistle-like flowers $1.25 \quad 10.00$

(R) Erigeron alpinus. Purple............ $1.50 \quad 12.00$

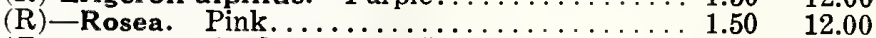

*Eupatorium Coelestinum. Lavender . . . . . . . .

*Euphorbia Corrollata. White............. $1.00 \quad 9.00$

Funkia Lanceolata. Lilac................. $1.25 \quad 10.00$

- Undulata varieg. picta. Variegated ............ $1.50 \quad 12.00$

-Argentea. Golden foliage...................... $1.75 \quad 15.00$

- Subcordata Grandiflora ............. $1.50 \quad 12.00$

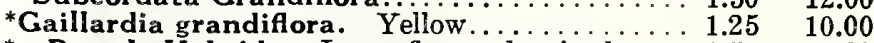

* - Portola Hybrids. Large flowered; mixed. . . . . $1.50 \quad 12.00$

* -Le Mastodonte. Yellow, red center......... $1.50 \quad 12.00$

Geum coccineum Mrs. Bradshaw. Fiery red..... $1.50 \quad 12.00$

-Lady Strathedon. Golden yellow . . . . . . . . . $1.50 \quad 12.00$

-Atrosanguineum. Crimson.............. $1.50 \quad 12.00$

${ }^{*}$ Gypsophila acutifolia. Lilac rose... . . . . \$1.50 \$12.00

*-Ehrli. Pure white double............ $3.00 \quad 25.00$

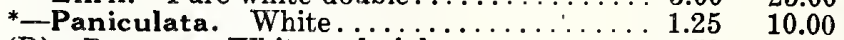

(R)-Repens. White and pink .......... $1.50 \quad 12.00$

*-Bristol Fairy. Double white........... $3.00 \quad 25.00$

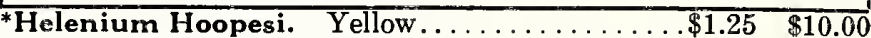

*-Riverton Gem. Old gold................... $1.25 \quad 10.00$

(R) Helianthemum Buttercup. Golden yellow. . $1.50 \quad 12.00$

(R) -Fireball. Red.................... 1.50 12.00

(R) Helianthemum Mutabile. Rose, white and yellow.............................. 17.50

*Heliopsis Lalvis. Golden yellow; daisy like..... $1.00 \quad 9.00$

-Pitcheriana. Deep yellow.............. $1.00 \quad 9.00$

* - Scabia zinniaflora. Large yellow............. $1.50 \quad \begin{aligned} & 9.00 \\ & 12.00\end{aligned}$

Hemerocallis Aurantiaca. Bright orange..... $1.25 \quad 10.00$

-Dr. Regal. Rich yellow.................. $1.50 \quad 12.00$

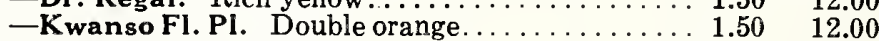

-Thunbergii. Yellow ................... $1.50 \quad 12.00$

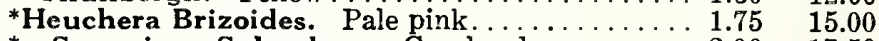

*-Sanguinea Splendens. Coral red........... 2.00 17.50

-Hibiscus Crimson Eye. White, crimson throat. . $1.00 \quad 9.00$

-Moscheutos Roseus. Bright pink.......... $1.00 \quad 9.00$

-Mallow Marvels. Mixed................ $1.00 \quad 9.00$

*Hollyhock, New Lilac Beauty. Double... . . . . $1.25 \quad 10.00$

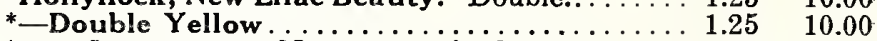

* - Imperator. New type, mixed .......... $1.50 \quad 12.00$

* - - Queen of Sheba. Primrose, rosy reflex . . . 2. $2.00 \quad 17.50$

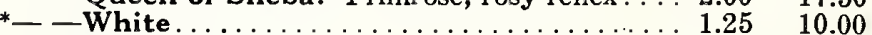

*-Maroon . . . .

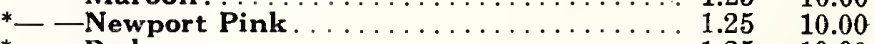

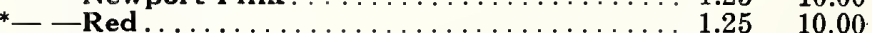

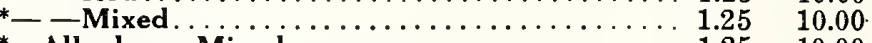

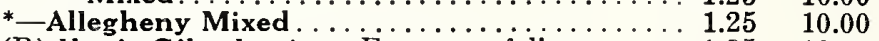

(R) lberis Gibraltarica. Evergreen foliage . . . . $1.25 \quad 10.00$

(R) -Sempervirens. White............ $1.25 \quad 10.00$

PLEASE NOTE.-Shipments of perishable goods can only be made at your risk.

If shipments arrive in bad condition, accept them and receipt for them accordingly and make claim for your loss on the transportation company. We, of course, hold ourselves ready to assist you in any possible way. It has been found that claims can be collected more readily by the person receiving the goods than by the shipper.

Varieties marked $\left({ }^{*}\right)$ are especially suitable for cutting, while varieties marked (R) are indispensable for rockeries (wh) 


\section{MICHELL'S HARDY PERENNIAL PLANTS}

\section{IRIS GERMANICA (German Iris)}

Per 10 Per 100

Afterglow. Grayish Lavender.............. \$0.75 $\$ 6.00$

Alcazar. Pale lilac standard, bronze throat...... $\quad .75 \quad 6.00$

Ambassadeur. Reddish violet standards, falls deep yellow. .

$\begin{array}{ll}1.75 & 15.00\end{array}$

Asia. Pale silvery lavender, purple falls . . . . . . $2.75 \quad 25.00$

Caprice. Purple, heavily veined...

.756 .00

Chasseur. Tallest and best yellow..

$2.25 \quad 18.00$

Dream. Soft clear pink.

Gold Imperial. Yellow, self colored.

$2.25 \quad 18.00$

$2.00 \quad 17.50$

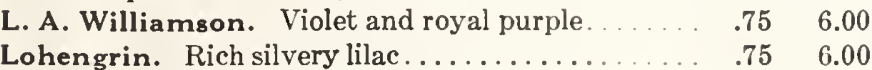

Loreley. Marine blue, bordered yellow ......... $\quad .75 \quad 6.00$

Mrs. Allen Gray. Beautiful rosy mauve........ $\quad .75 \quad 6.00$

$\begin{array}{lll}\text { Madam Chobaut. Cream, shaded buff and pink . . } 2.00 & 17.50\end{array}$

Nibelungen. Deep olive-buff with violet falls . . . . $\quad .75 \quad 6.00$

Opera. Bright violet red............... $1.75 \quad 15.00$

Primrose. Deep yellow, falls paler............ $3.25 \quad 27.50$

Queen Caterina. Lavender violet, orange beard . . $1.25 \quad 10.00$

Regan. Violet standards, ageratum falls......... $\quad .75 \quad 6.00$

Shekinah. Pale yellow, lemon colored beard....... $1.25 \quad 10.00$

True Delight. Pure white, edged bright yellow, deep

maroon falls..................... $2.25 \quad 18.00$

\section{IRIS KAEMPFERI（Japan IrIs)}

Astarte. Double, dark violet.

Per 10 Per 100

.\$1.50\$12.00

Gekka-No-Nomi. White; very early . . . . . . . . $1.50 \quad 12.00$

Gold Bound. Fine double pure white........ $1.50 \quad 12.00$

Hercule. Double, clear lilac................. $1.50 \quad 12.00$

Iso-No-Nami. Double blue, silvery veins . . . . . . . $1.50 \quad 12.00$

Kagaribe. Lavender with yellow spot......... 2.00 $\quad 17.50$

Koko-No-Iro. Purple and gold . . . . . . . . . . . $1.50 \quad 12.00$

Melpomene. Soft blue; double............. $1.50 \quad 12.00$

Mahogany. Purplish mahogany red.......... $1.50 \quad 12.00$

Neptune. Mahogany colored . . . . . . . . . . . $1.50 \quad 12.00$

Patrocle. Single, dark violet. . . . . . . . . . . $1.50 \quad 12.00$

Prosperpine. Single, rich blue on white........ $1.50 \quad 12.00$

Reine des Bulgares. Deep blue, white veins . . . . $1.50 \quad 12.00$

Ski-No-Roy. Double blue and white... . . . . . $1.50 \quad 12.00$

Sueren. Pure white with cream stigma . . . . . . 2.00 17.50

Uchiu. Cerulean blue, golden center........... $1.50 \quad 12.00$

William Tell. Cream white with lilac......... $3.50 \quad 30.00$

Yezonishitai. Red lavender shaded purple...... $2.00 \quad 17.50$

*Lathyrus Latifolius White Pearl......... 1.00

*_-Pink....................... 1.00

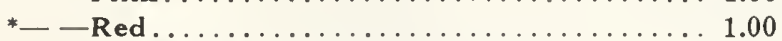

*Lavendula Vera. True sweet lavender........ 1.50

(R) Leontopodium alpinum (Edelweiss) . . . . 1.50

${ }^{*}$ Liatris pycnostachia. Rich purple......... 1.25

*-Scariosa. Purple.................... 1.25

${ }^{*}$ Lupinus Polyphyllus White.... . . . . . . . . 1.50

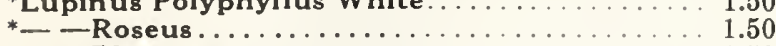

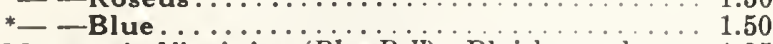

Monarda Didyma Cambridge Scarlet (Oswego

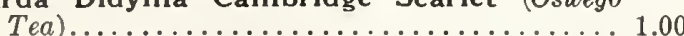

(R) Myosotis Palustris Semperflorens. Rich blue 1.00

(R) Nepeta Mussini (Ground Ivy). Lavender..... 1.50

(R) Oenothera Missouriensis. Yellow............

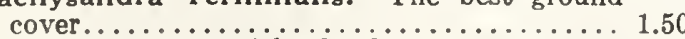

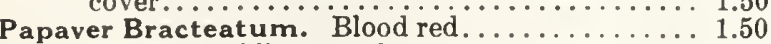

Papaventale. Brilliant scarlet.......................... $1.50 \quad 12.00$

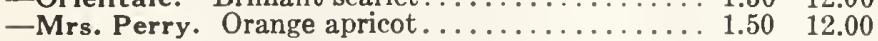

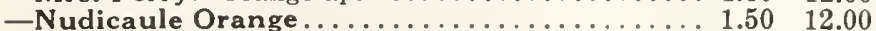

- White............................... 1.5012 .00

- - Yellow................................ 1.5012 .00
HARDY PHLOX (Phlox decussata)

Per 10 Per 100

Africa. New. Brilliant carmine red

$\$ 1.50 \$ 12.00$

Baron v. Dedem. Blood red.

Baur's Pink. Brilliant deep pink.

Beacon. Brilliant cherry red

B. Compte. Amaranth.

Brilliant. New deep rose.

Commander. New. Crimson red

Deutschland. Brilliant red.

Firebrand. Brilliant orange scarlet

Jules Sandeau. Pink.

Miss Lingard. Pearly white

Mme. P. Langier. Bright red

Mme. P. Dutrie. Soft pink. .

M. French. New. Vermilion

Pantheon. The peerless pink

Rheinlander. Salmon-pink with claret eye.

1.50

1.00

1.00

1.00

1.50

1.50

1.00

1.50

1.50

1.00

1.00

1.25

1.50

R. P. Struthers. Rosy carmine, shaded orange 1.00

Sir Edwin Landseer. Bright crimson . . . . . . 1.00

Special French. Glowing pink.

Von Lassburg. Pure white

Von Hochberg. Brilliant red.

12.00

9.00

9.00

12.00

12.00

9.00

12.00

9.00

9.00

10.00

12.00

9.00

9.00

9.00

9.00

9.00

9.00

1.00

12.00

\section{Phlox SUbulata (Moss Pinks)}

Most valuable for the rockery, the border and for carpeting.

Amoena. Pink.

Alba. Pure white

Per 10 Per 100

Lilacina. Light lilac.

$\$ 1.00 \$ \$ 9.00$

Rosea. Rose pink.

$\begin{array}{rr}1.00 & 9.00 \\ 1.00 & 9.00\end{array}$

$\begin{array}{rr}1.00 & 9.00 \\ & 1.00\end{array}$

Vivid. Bright pink, fiery red eye .......... $1.50 \quad 12.00$

G. F. Wilson. Lavender

$\begin{array}{ll}1.50 & 12.00\end{array}$

*Pentstemon Coral Gem. Coral pink....... \$1.50 \$12.00

*-Laevigatus. Pure white.............. $1.50 \quad 12.00$

*-Shell Pink...................... $1.50 \quad 12.00$

*_Campanulatus Purpureus. Purple......... 1.50 12.00

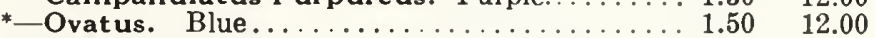

*Physalis Francheti (Chinese Lantern Plant) .... $1.00 \quad 9.00$

*Physostegia Virginiana. Purplish red and pink.. $1.25 \quad 10.00$

*-Alba. Pure white............ $1.25 \quad 10.00$

*_Virginica Vivid. Deep pink...................... 1.2510 .00

(R) Platycodon Grandiforum. Blue ........ $1.25 \quad 10.00$

(R) - - Alba. White........... $1.25 \quad 10.00$

(R)-Mariesi Alba. Dwarf white................ $1.25 \quad 10.00$

(R)-Grandif. Nanum Album. Dwarf white... $1.25 \quad 10.00$

(R) Plumbago Larpentae. Deep blue ....... $1.25 \quad 10.00$

*Pyrethrum Atrosanguineum. Dark crimson. . $1.25 \quad 10.00$

*-Roseum Hybridum. Shades of pink and red... $1.25 \quad 10.00$

*-Uliginosum. White.. $.25 \quad 10.00$

*Ranunculus Acris Fl. Pl. Golden yellow ....... $1.50 \quad 12.00$

*Rudbeckia Newmanni. Orange, purple cone.... $1.00 \quad 9.00$

Salvia Azurea Grandiflora. Sky-blue. . . . $\quad 1.00 \quad 9.00$

-Pitcheri. Deep indigo blue................... $1.25 \quad 10.00$

*Scabiosa Caucasica. Lavender................ 1.50 12.00

(R) Sedum Acre (Mossy Stone Crop) ........... $1.00 \quad 9.00$

-Album. Foliage green, flowers white.......... $1.00 \quad 9.00$

-Kamschaticum. Orange stone crop........ $1.00 \quad 9.00$

-Sarmentosum. Forms soft carpet; yellow .... $1.25 \quad 10.00$

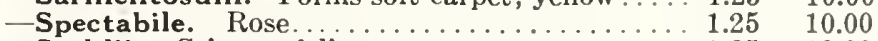

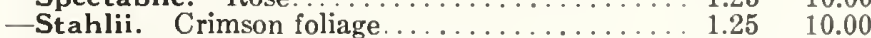

Sidalcea Rosy Gem. Bright rose........... $1.50 \quad 12.00$

${ }^{*}$ Stokesia Cyanea (Blue Cornflower Aster) . . . . . . . . $1.25 \quad 10.00$

*Statice Latifolia (Sea Lavender). Blue......... 1.25 10.00

*Thalictrum Aquilegifolium. White......... 1.25 10.00

*-Adiantifolium. Yellow.

(R) Thymus Albus. Pure white

(R)-Coccineus. Bright red

Tritoma Pfitzeri (Red Hot Poker)

Trollius Europaeus (Globe Flower). Yellow

(R) Tunica Saxifraga. Pink.

*Valeriana Coccinea. Old rose

*-Officinalis. Rose, tinted white.

(R) Veronica Amethystina. Amethyst blue

(R)-Elegans. Pink

*-Longifolia Subsessilis. 'Deep blue

(R) - R upestris. Blue.......

1.25

1.50

1.50

1.50

1.50
1.00

1.00

1.00
1.25

1.25

1.50

1.50

1.50 


\section{FERENNIALS FOR FORCING}

Owing to the ever increasing popularity of Hardy Perennials for Forcing, we offer herewith an assortment of such varieties, which will do best for that purpose. Any one of these will prove a moneymaker and every Florist should grow at least a few of them.

All Forcing Perennials, which we send out are properly prepared and frost cured before shipping and are ready for immediate planting, when received. This is part of our service to our patrons.

Price

Campanula Medium Blue . . . . . . . . . $\$ 1.00 \$ 9.00$

per 10 per 100

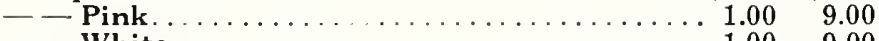

- White........................... $1.00 \quad 9.00$

C - Pink...................... $1.00 \quad 9.00$

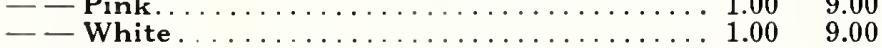

Delphinium Belladonna (2 year old). Clear tur-

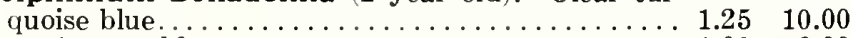

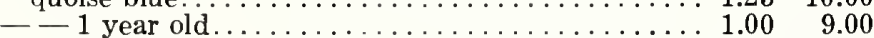

- Bellamosum (2 year old). Dark blue .......... 1.2510 .00

- -1 year old ...................... $1.00 \quad 9.00$

- English Hybrids (Blackmore \& Langdon Strain).

All colors, stems about 30 inches long (2 year old). .

Dielytra Spectabilis (Bleeding Heart)............ $3.50 \quad 30.00$

Elder Daisy (True Memorial Daisy)............. $1.50 \quad 12.00$

While they never fail to flower outdoors on $\mathrm{Me}$ morial Day, they give wonderful results in a cool house. Plant on a bench in a 45 degree house in January, which will give a great quantity of flowers in late March and April, surpassing in size and length of stem anything in the way of Marguerites.

Funkia Undulata Variegata. Pot up in January and in a few weeks will make attractive pot plants. 1.50

Violets "Prince of Wales." Single deep blue. The

best of all. ...................... 1.50

12.00

12.00

\section{MICHELL'S SELECT PAEONIES}

\section{A SELECT LIST OF THE BEST VARIETIES}

The divisions of varieties listed are of 3 to 5 eyes from twoyear-old clumps, with balanced roots, free from disease, and absolutely true to name.

Price

per 10 per 100

Albatre. Pure white, carmine on center petals. . \$ $\$ 2.75 \$ 22.50$

Albert Crousse. Soft shell pink............. $3.00 \quad 25.00$

Alexander Dumas. Brilliant pink................ $2.75 \quad 22.50$

Baroness Schroeder. White with shadings of flesh $4.50 \quad 40.00$

Chas. McKellipp. Rich crimson . ...........4.50 40.00

Chestine Gowdy. Silvery pink . . . . . . . . $4.50 \quad 40.00$

Duchess De Nemours. Pure white, sulphur white collar.

Edulis Superba. Deep mauve pink....

Eugenie Verdier. Flesh pink.

Felix Crousse. Medium bright red .......... 4.00

Festiva Maxima. Pure white, crimson markings . . 3.00

Floral Treasure. Midseason pink........... 2.75

Germaine Bigot. Excellent pink.......... 4.00

Jeanne De Arc. Soft pink, with sulphur, white and

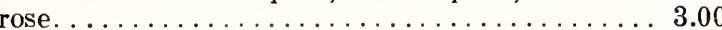

Jubilee. Ivory white . . . . . . . . . . . . .

Karl Rosenfield. Pure rich crimson......... 4.00

Kelways Queen. Mauve-rose, with carmine pink. $\$ 3.50$ each

La Fee. Mauve rose, collar creamy white.

$\$ 1.25$ each 11.00

La Perle. Delicate lilac-white, center violet rose. 5.00

Madam Crousse. Soft salmon pink........... 3.00

Marie Jacquin. Cup-shaped white flowers. . . . . 3.50

Modeste Guerin. Light solferino red........ 3.00

Mons. Du Pont. Ivory white, center carmine... . 4.00

Mons. Jules Elie. Glossy lilac pink.......... 5.00

Mme. August Dessert. Violet rose, center carmine 6.00

Pres. Roosevelt. Deep, rich brilliant red....... . 5.00

Primevere. Sulphur white, deep sulphur yellow center. $\$ 1.25$ each . . . . . . . . . . . . 11.00

Reine Hortense. Uniform hydrangea pink . . . . 5.00

Sarah Bernhardt. Apple blossom pink ....... 6.00

Souv. De Chas. Gombault. Rose pink, cream col-

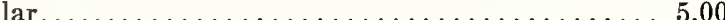

Therese. Rich satiny pink. $\$ 1.25$ each.......... 11.00

22.50

35.00

25.00

22.50

35.00

25.00

50.00

35.00

\section{ROSES FOR EASTER FORCING}

We supply extra strong, 2 year old budded stock, strictly A No. 1 Grade. Ready November and December. Price per 10 per 100

Baby Rambler (Mme. Levavasseur). Crimson. . . . $\$ 4.00 \$ 35.00$ Baby Edith Cavell. Brilliant scarlet......... $4.00 \quad 35.00$ Baby Ellen Poulson. Cherry pink.......... $4.00 \quad 35.00$

Baby Erna Teschendorf. Rose pink........ 4.00 35.00

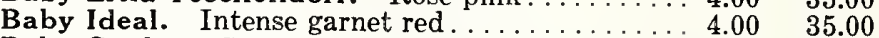

Baby Gurley. Strong grower; deep crimson . . . . . . 4.00 35.00

Baby Lafayette. Brilliant cherry red......... 4.00 35.00

Baby Orleans. Geranium red .............. $4.00 \quad 35.00$

Baby Triomphe d'Orleans. Cherry red......... 4.00 35.00

Baby Verdun. Deep rose................ 4.00 35.00

Climbing Eugene Jacquet. Cherry red......... $4.00 \quad 35.00$

Climbing Paul's Scarlet. Best scarlet....... . 4.00 35.00

Magna Charta. (H. P.) Bright pink......... 4.00 35.00

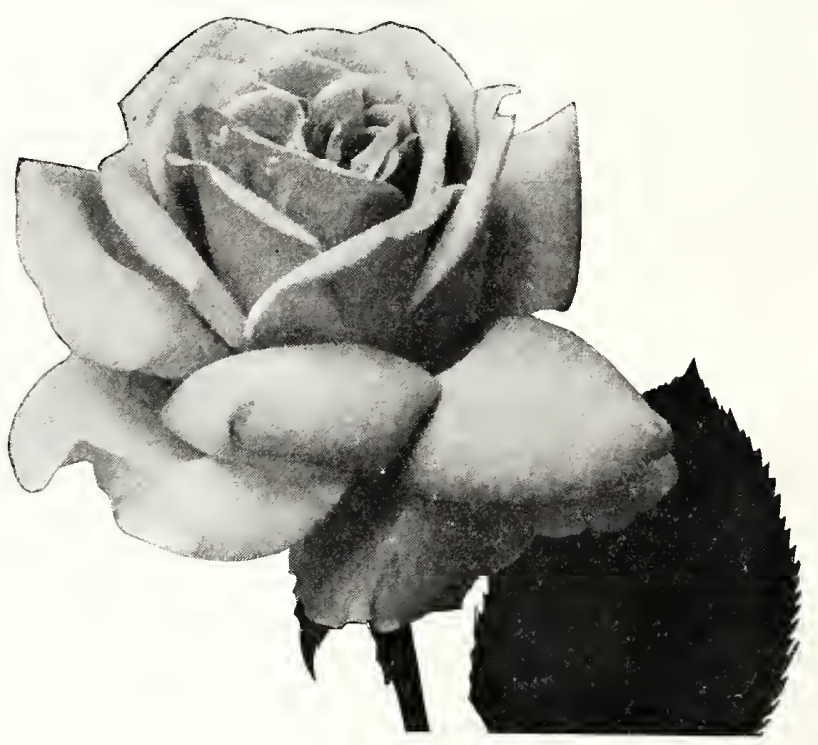

Iybrid Tea Rose, Columbia

\section{MICHELL'S ROSES FOR SPRING SALES}

Extra heavy A No. 1 Grade (ready in December).

Betty. (H. T.) Coppery rose.

22.50 Briarcliff. (H. T.) Glowing rose pink.

22.50 Chas. K. Douglas. (H. T.) Crimson scarlet.

Columbia. (H. T.) Rose pink.

Etoile de France. (H. T.) Crimson.

Gen. Mac Arthur. (H. T.) Crimson scarlet.

Gruss an Teplitz. (H. T.) Brilliant crimson.

Independence Day. (H. T.) Orange apricot.

J. J. L. Mock. (H. T.) Deep imperial pink.

John Russell. (H. T.) Large crimson.

Killarney Pink. (H. T.) Beautiful pink.

Lady Hillingdon. (H. T.) Deep apricot yellow.

Los Angeles. (H. T.) Flame pink.

Mme. Butterfly. (H. T.) Soft pink.

Mme. Caroline Testout. (H. T.) Satin rose.

Mme. Edouard Herriot. (H. T.) Coral red.

45.00 Mme. Jules Bouche. (H. T.) Pure white, tinted pink.

25.00 Miss Lolita Armour. (H. T.) Chrome yellow.

32.50 Mrs. Aaron Ward. (H. T.) Indian yellow.

25.00 Mrs. Henry Bowles. (H. T.) Clear pink.

35.00 Mrs. Wakefield Christie Miller. (H. T.) Beautiful soft pink.

45.00 Mons. Julien Potin. (H. T.) Pure flesh pink.

55.00 Radiance. (H. T.) Bright pink.

45.00 Red Radiance. (H. T.) Cerise red.

Rev. F. Page Roberts. (H. T.) Golden yellow, edged red.

Talisman. (H. T.) Yellow, gold and pink.

45.00 William F. Dreer. (H. T.) Yellow, shaded old rose.

55.00 Willowmere. (H. T.) Rich pink, yellow sheen.

Price of the above varieties, $\$ 4.00$ per 10 ; per $100, \$ 35.00$.

45.00 Put up in bundles of 10 . We cannot furnish less than 10 of a variety and no order will be executed for less than 50 plants. 


\section{MICHELL'S “DISTINCTIVE” FLOWER SEEDS}

"Distinctive" Strains of Flower Seeds for the florist is one of our specialties and no trouble or expense is spared in our endeavor to supply only the best and most improved strains, both from home and foreign growers.

For full descriptions see our Retail Catalog, a copy of which will be mailed free upon application.

NOTE-Half trade packets are only supplied where listed; where smaller quantities are wanted than that listed, retail packets may be ordered at a discount of $331 / 3$ per cent. from our retail catalog prices.

On all Flower Seeds quoted in this Catalog there is no extra charge for Parcel Post, excepting for Special Delivery or Insurance.

\begin{tabular}{|c|c|c|c|}
\hline \multicolumn{4}{|c|}{ Fractions of ounces are supplied as follows } \\
\hline Where price & Where price & & \\
\hline per oz. is & per oz. is & $1 / 2 \mathrm{oz}$ & $1 / 4 \mathrm{oz}$. \\
\hline $\begin{array}{l}\$ 0.15 \\
20\end{array}$ Where price per & $\begin{array}{r}\$ 0.65 \\
75\end{array}$ & $\$ 0.35$ & $\$ 0.20$ \\
\hline .25 less, half ounces & 1.00 & .50 & 30 \\
\hline .30 can be supplied & 1.25 & .65 & .35 \\
\hline .35 at a slight in- & 1.50 & .75 & .40 \\
\hline .40 crease in price. & 1.75 & .90 & .50 \\
\hline $.50 \quad 1 / 2 \mathrm{oz} .1 / 4 \mathrm{oz}$. & 2.00 & 1.00 & .60 \\
\hline$\$ 0.30 \$ 0.20$ & 2.25 & 1.15 & .60 \\
\hline & 2.50 & 1.25 & .65 \\
\hline
\end{tabular}

\section{ACANTHUS}

Latifolius. A stately perennial foliage plant with Trade pkt. Oz. large decorative leaves.

\section{ACHILLEA}

Ptarmica, A. pl. "The Pearl." Perennial, flowering continuously all summer; pure white double flowers

\section{ACONITUM (Monk's Hood}

Napellus. Perennial; long spikes of blue flowers. .

\section{ADONIS}

Vernalis. A choice spring flowering perennial; large yellow flowers.

\section{A GROSTEMMA (Mullein PInk}

Hardy perennial; silvery foliage, showy flowers.

Coronaria. Deep crimson ................... 15

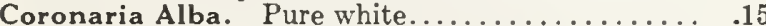

\section{ALYSSUM}

Michell's Bouquet. Forms a perfect bouquet of miniature white flowers; a perfect gem for edging. $(1 / 4 \mathrm{lb} ., \$ 2.75 ; \$ 5.00$ per $1 / 2 \mathrm{lb}$.

Saxatile Compactum. Perennial; golden yellow. . .20

\section{AMPELOPSIS}

Veitchi (Boston or Japanese Ivy) ......(1/4 lb., \$0.75) $\quad .15$

\section{ANCHUSA}

An excellent hardy perennial; very popular. Italica, "Dropmore Variety." Bright blue

Italica, Opal. Large pale blue flowers.........

\section{ANEMONE (Windflower)}

Hardy perennial; excellent for cutting.

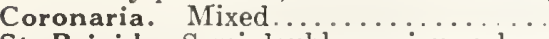

St. Brigid. Semi-double; various colors

\section{ANTHEMIS Hardy Marguerite}

Tinctoria Kelwayi. Daisy-like, bright yellow flowers; excellent for cutting

\section{ARABIS (Rock Cress)}

Alpina. Dwarf, spring flowering perennial for edging and rockery; flowers pure white.............

ARMERIA (Sea Pink or Thrift)

Formosa. A fine edging or rockery plant, with deep

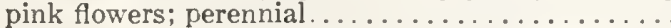
Laucheana. Perennial; flowers bright, rosy red.

\section{ANTIRRHINUM}

\section{Special Forcing Varieties}

Afterglow (New). Golden bronze. Trade pkt., $\$ 1.50$; $\$ 7.00$ uer 5 pkts.

Rose Queen (New'). Dark pink. Trade pkt., $\$ 2.00$; $\$ 5.00$ per 3 pkts.

Happiness (New). This super variety is the latest novelty in this class; color clear pink, neither washy or dull; flowers large, with smiling faces-whence its name. Trade pkt., $\$ 2.00$.

Ceylon Court. Canary yellow. Trade pkt., $\$ 1.00$; $\$ 2.50$ per 3 pkts.

Chapman's Pink. Premier Rose color. Trade pkt., $\$ 1.00 ; \$ 2.50$ per 3 pkts.

Chapman's Yellow. Trade pkt., $\$ 1.00 ; \$ 2.50$ per 3 pkts.

Cheviot Maid. Clear pink. Trade pkt., $\$ 1.00 ; \$ 2.50$ per 3 pkts.

Geneva Pink. Glistening rose pink. Trade pkt., $\$ 1.00 ; \$ 2.50$ per 3 pkts.

Golden Pink Queen. Trade pkt., $\$ 1.00 ; \$ 2.50$ per 3 pkts.

Helen. Lovely salmon color. Trade pkt., $\$ 1.00 ; \$ 2.50$ per 3 pkts.

Jennie Schneider. True Columbia Rose color. Trade pkt., $\$ 1.00 ; \$ 2.50$ per 3 pkts.

Judd's Early Dark Pink. Trade pkt., $\$ 1.00 ; \$ 2.50$ per 3 pkts.

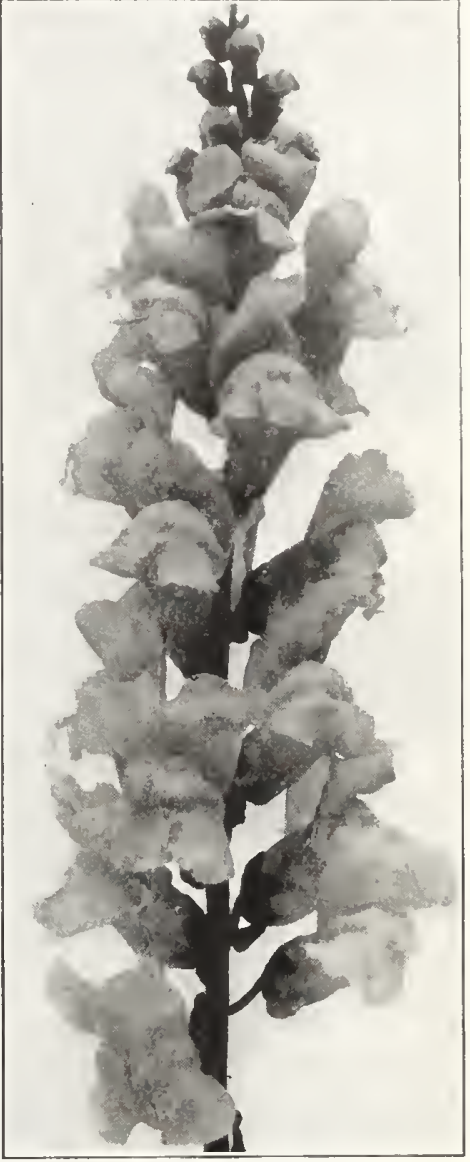

Antirrhinum, Ceplon Conrt
Judd's Early Light Pink. Trade pkt., $\$ 1.00 ; \$ 2.50$ per 3 pkts.

Keystone. Rose pink. Trade pkt., 50c.; $\$ 1.00$ per $1 / 8 \mathrm{oz}$.

Michell's Salmon Pink. Long spikes. Trade pkt., 30c.; $\$ 2.00$ per oz.

Orlando. Beautiful bronze color. Trade pkt., 75c.; $\$ 1.50$ per $1 / 8$ oz.

Philadelphia Pink. Pure pink. Trade pkt., 50c.; $\$ 1.00$ per $1 / 8$ oz.

Philadelphia Pink. Originator's stock. Trade plit., $\$ 1.00$; $\$ 5.00$ per 6 pkts.

Roman Gold. Deep golden yellow, suffused pink. Trade pkt., $\$ 1.00 ; \$ 2.50$ per 3 pkts.

Silver Pink (Ramsburg's). Trade pkt., 50c.; $\$ 1.25$ per $1 / 8 \mathrm{oz}$.

Improved Sunburst. Color of Sunburst Rose. Trade pkt., $\$ 1.00 ; \$ 2.50$ per 3 pkts.

White Rock. Extra early, pure white. Trade pkt., $\$ 1.00 ; \$ 2.50$ per 3 pkts.

\section{MAXIMUM VARIETIES}

Extra large flowers on strong stems. These are also forcing

.15 .50 varieties.

center...$\% 0.30 \quad \$ 2.00$

Cattleya. 'Silvery rosy lilac.................. $\quad .30 \quad 2.00$

Copper King (Indian Summer), Coppery scarlet... $\quad .30 \quad 2.00$

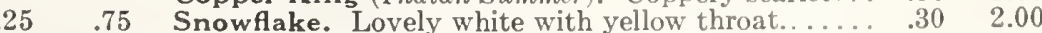

$.40 \quad 4.00 \quad$ Mixed Colors. Maximum varieties....................... 


\section{AQUILEGIA (Columbine)}

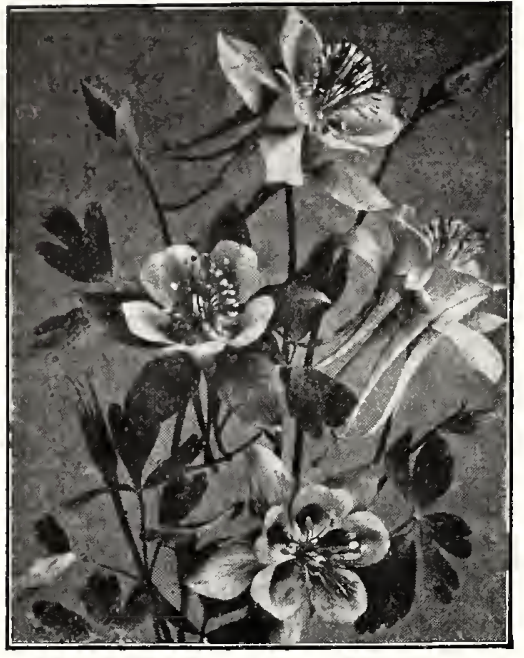

Aquilegia, Long Spurred per oz. per oz.
One of the most popular hardy perennials and very desirable for cutting. Californica Hybrida. Mixed colors. Trade pkt., 40c.; $\$ 2.00$ per oz.

Canadensis. Scarlet and yellow. Trade pkt., 50c.; $\$ 2.50$ per oz.

Chrysantha. Yellow. Trade pkt., 40c.; $\$ 2.00$

Coerulea. Blue and white. Trade pkt., 40c.; $\$ 2.00$ per oz.

Nivea Grandiflora. Pure white. Trade pkt., 25c.; $\$ 1.00$ per oz.

Rose Queen. Deep rose. Trade pkt., 50c.; $\$ 3.50$

Double Mixed. Trade pkt., 15c.; 60c. per oz. Single Mixed. Trade pkt., 15c.; 50c. per oz.

\section{LONG SPURRED VARIETIES}

An extra fine strain producing large flowers.

Blue Shades. Trade pkt. Oz. $\ldots 0.50 \quad \$ 3.50$

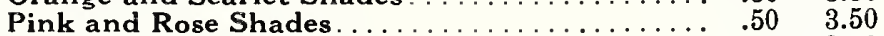
Snow Queen. Pure white. .................... $\quad .50 \quad 3.50$

Mrs. Scott Elliot's Select Strain............... .60 4.00

\section{ASPARAGUS PLUMOSUS NANUS}

This has been one of our specialties for many years; our seeds are of high germination and will produce extra fine stock.

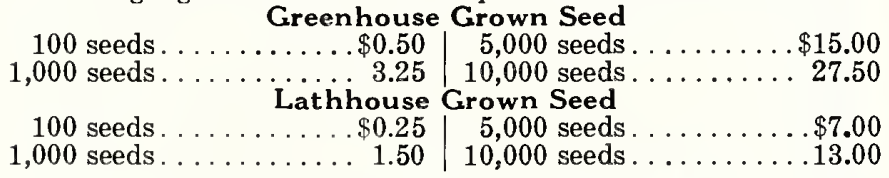

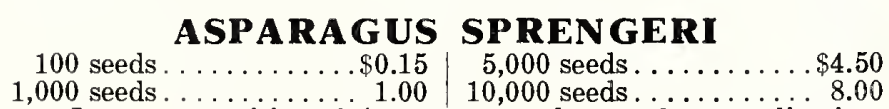

Larger quantities of Asparagus seed quoted on application.

ASPERULA Trade pkt. Oz.

Odorata (Sueet Woodruff). Dwarf, hardy perennial with white flowers.

$\$ 0.20 \quad \$ 0.75$

\section{PERENNIAL ASTER (Michaelmas Daisy)}

One of the showiest of our late flowering perennial plants; star-like single flowers.

Alpinus. Purple with large yellow center Trade pkt. Oz. Alpinus Albus. White . . . . . . . . . . . . . . . . $\quad .40 \quad 2.00$ Choice Mixed.

$.40 \quad 2.00$

\section{A UBRIETIA}

Deltoides. A dwarf, spring flowering perennial; fine for rockeries; lavender blue flowers.

AURI CULA (Primula Auricula)

Choice Mixed. Hardy perennial with flowers of many beautiful colors.

\section{BAPTISIA (False Indigo}

Australis. Tall showy perennial plants, with spikes of deep blue flowers

\section{BOCCONIA (Plume Poppy)}

Cordata. Hardy perennial; creamy white flowers.

Elata Coerulea. Blue

\section{BROWALLIA}

Speciosa Major. Most desirable variety as a pot or basket plant; large, rich blue flowers

\section{BEGONIA SEMPERFLORENS}

An excellent bedding plant for semi-shady locations; also valuable as pot plants for winter flowering. Easily grown from seed.

Christmas Cheer. Bright, crimson scarlet; fine for Trade pkt. Oz.

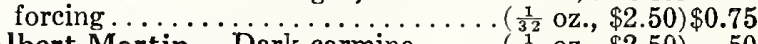

Albert Martin. Dark carmine........ ( $\left(\frac{1}{32}\right.$ oz., $\left.\$ 2.50\right) \quad .50$

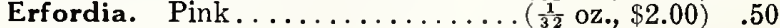

Glory of Erf urt (Improved). Rosy carmine; flowers

large....................... ( $\frac{1}{32}$ oz., \$3.00) 1.00

Gustave Knaake. Large flowering pink, salmon

shadings; splendid for pot culture.... ( $\frac{1}{32}$ oz., $\left.\$ 2.50\right) 1.00$

Salmon Queen. Salmon red.......( $\frac{1}{32}$ oz., $\left.\$ 2.00\right) \quad .50$

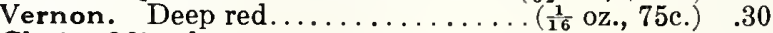

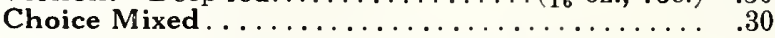

$\$ 3.50$

\section{BEGONIA GRACILIS}

This type produces very compact little plants that are literally covered with flowers; an easy seller.

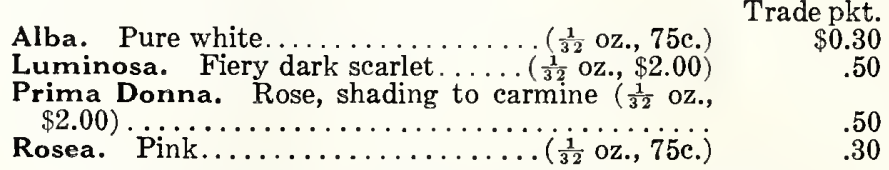

BEGONIA, TUBEROUS ROOTED

These are easily raised from seed, produce enormous flowers and are excellent for bedding, window boxes or pot culture.

Single Mixed $\ldots \ldots \ldots \ldots \ldots \ldots \ldots\left(\frac{1}{32}\right.$ oz., $\left.\$ 3.00\right)$
Trade pkt.
$\$ 1.00$
1.00

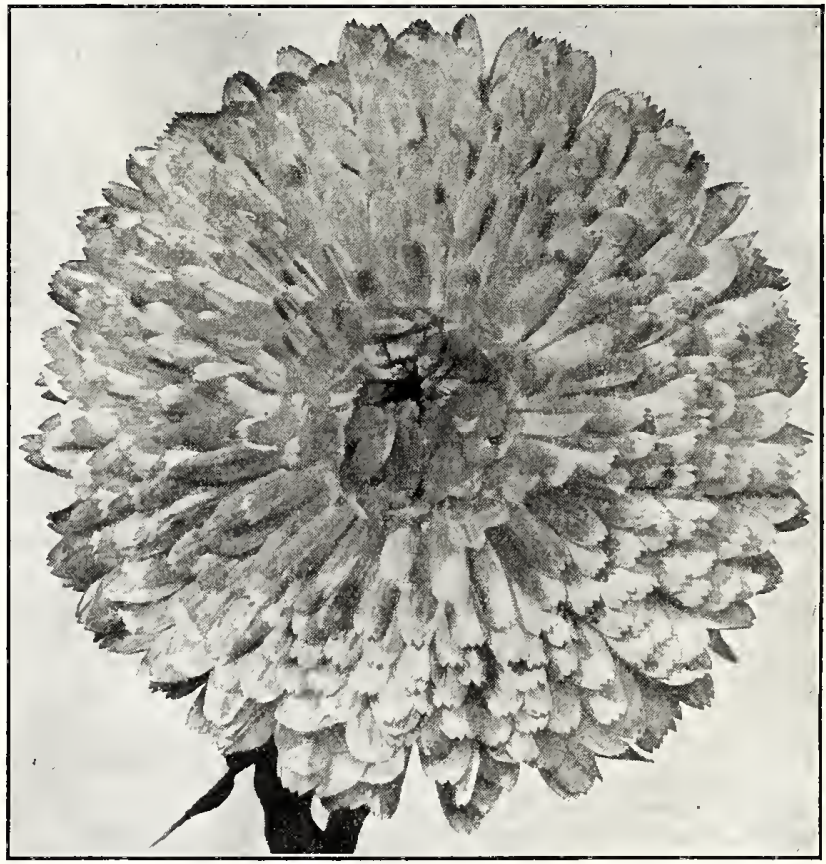

Calendula, Campfire (Sensation)

CALENDULA (Pot Marigold)

Raised extensively as a pot plant or for bedding; also for cutting.

Campfire (Sensation). Brilliant orange with scarlet

sheen; full yellow center...........(1/4 oz., 75c.) $\$ 0.50 \quad \$ 2.50$

Radio. Flowers full, petals quilled; color, rich glowing orange........ (1/4 oz., $65 \mathrm{c} . ; \$ 7.00 \mathrm{per} 1 / 4 \mathrm{lb}$.

Michell's Special Forcing, Orange. We have an extra fine strain of this forcing variety $(1 / 4 \mathrm{lb}$.,

$\$ 3.50 ; \$ 6.50$ per $1 / 2 \mathrm{lb}.) \ldots \ldots \ldots \ldots \ldots \ldots \ldots \ldots \ldots \ldots$
Ball's Supreme. Cadmium orange, dark brown center.................... (1/4 oz., 75c.)

Ball's Gold. An extra long stemmed, deep golden yellow.......... (1/4 oz., 65c.; $\$ 7.00$ per $1 / 4 \mathrm{lb}$.

Ball's Orange. Large, double glowing orange flowers on long stems . . . (1/4 oz., $65^{n} .: \$ 7.00$ per $1 / 4 \mathrm{lb}$.) 


\section{MICHELL'S “DISTINCTIVE” FLOWER SEEDS}

\section{CLEMATIS}

Paniculata. A popular hardy climber; white star-

Trade pkt. Oz. shaped flowers................. (1/4 lb., \$1.50)\$0.15 $\$ 0.50$

\section{COREOPSIS}

A splendid hardy perennial, and excellent for cutting.

Trade pkt. Oz.

California Sunbeams. Large flowers; yellow and brown ......................... \$0.15 $\$ 0.50$

Lanceolata Grandiflora. Large golden yellow . ... $\quad .15 \quad .30$

Lanceolata Grandiflora Fl. Pl. (Double Flowering

Coreopsis). Double and semi-double flowers

$.25 \quad 1.00$

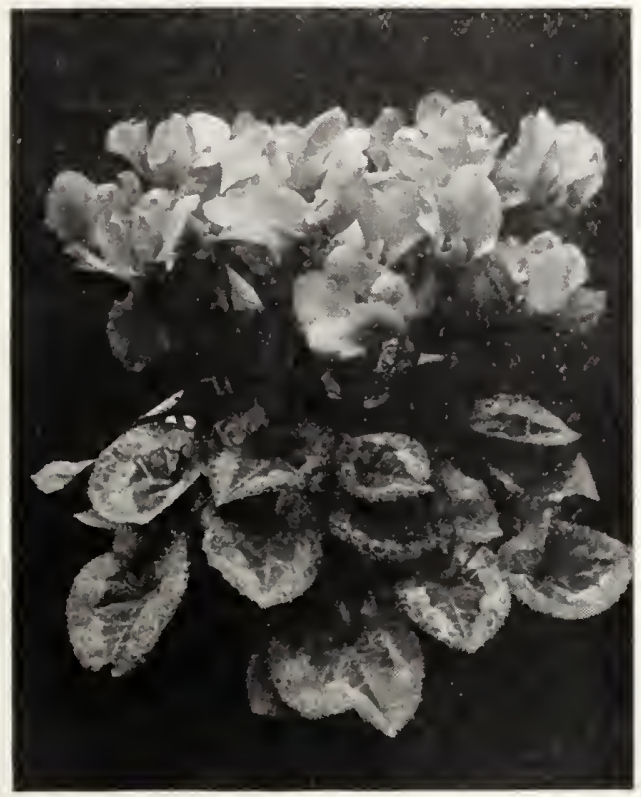

Michell's Giant Show Cyclamen

CYCLAMEN-Michell's Glant Show

Our Cyclamen seed is grown for us by specialists, seed being selected only from plants of superior bloom and foliage. (Binneweis Strain)

Seeds Seeds Seeds Seeds 10,000

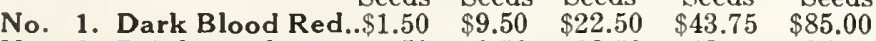

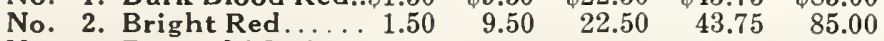

No. 4. Rose of Marien-

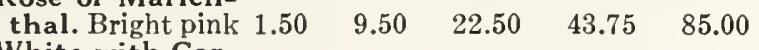

No. 5. White with Car-

$$
\begin{array}{llllll}
\text { mine Eye..... } 1.50 & 9.50 & 22.50 & 43.75 & 85.00
\end{array}
$$

No. 6. Pure White ... $1.50 \quad 9.50 \quad 22.50 \quad 43.75 \quad 85.00$

$\begin{array}{lllll}\text { No. 8. Improved Salmon } 2.00 & 13.50 & 32.50 & 63.75 & 125.00\end{array}$

No. 9. Salmon Scarlet. . $2.25 \quad 15.50 \quad 37.50 \quad 73.75 \quad 145.00$

No. 10. Glory of Wands-

$$
\text { bek. Salmon red. } 1.75 \quad 11.50 \quad 27.50 \quad 53.75 \quad 105.00
$$

No. 11. Rose of Zehlen-

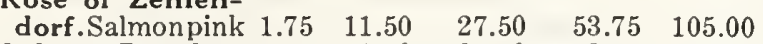

No. 12. Salmon Purple. . $1.75 \quad 11.50 \quad 27.50 \quad 53.75 \quad 105.00$

No. 16. Safranin Red... $2.25 \quad 16.00 \quad 38.75 \quad 76.25 \quad 150.00$

$\begin{array}{lrrrr}\text { Mixed Colors............ } 1.35 \quad 9.00 & 21.25 & 41.25 & 80.00\end{array}$

Glowing Dark Red. Christ-

\section{Ferd Fischer's Glant Strain}

mas red.....................

Rose of Ma rienthal.

Bright rose. 150

Pure White............

White with Carmine Eye 1.50

Glory of Wandsbek. Sal-

mon red............. 1.

$\begin{array}{ccccc}\text { mproved Rose of Zehlen- } & & & & \\ \text { dorf......................... } 1.75 & 11.50 & 27.50 & 53.75 & 105.00 \\ \text { Bonfire. Brilliant salmon. } 2.00 & 14.00 & 33.75 & 66.25 & 130.00\end{array}$

America. Golden salmon $\begin{array}{lllll}2.25 & 16.00 & 38.75 & 76.25 & 150.00\end{array}$

\section{CYPERUS}

Alternifolius (Umbrella Plant)..

Trade pkt. $\mathrm{Oz}$. $\$ 0.30 \$ 1.25$

\section{DAISY, ENGLISH DOUBLE}

\section{(Bellis Perennis)}

The Monstrosa varieties surpass all other strains in their strong robust growth and extra large double flowers.

Monstrosa Etna. Dark red............

Trade pkt. Oz.

Monstrosa Pink.

Monstrosa White.

Monstrosa Mixed.

Double Mixed. A fine mixture

$\$ 0.75 \$ 4.00$

$\begin{array}{lr}.50 & 3.00\end{array}$

$.50 \quad 3.00$

$.50 \quad 2.50$

$.30 \quad 1.50$

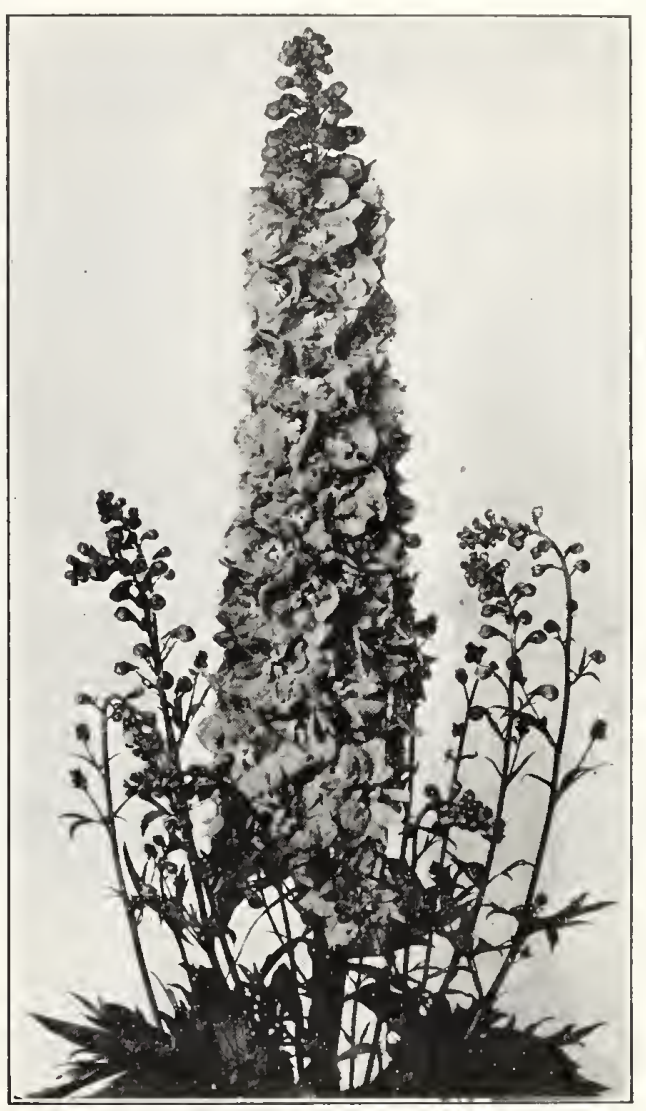

Delphinium, English Hollyhock

DELPHINIUM (Perenniai Larkspur)

One of the most popular perennials; excellent for cutting.

English Hollyhock (Watkin Samuels' Wrexham Strain). The finest large flowered type to date; colors range from delicate Belladonna blue to deepest blues and purples; long flower spikes. Selected mixture ................................

Blackmore and Langdon's. A selected English
variety; immense spikes of large flowers; very choice mixture.

tu. . . .

Belladonna. Light turquoise blue...( $(1 / 4 \mathrm{lb} ., \$ 7.00)$
Belladonna Improved. An improved selection of

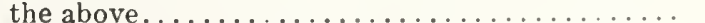

Bellamosum. A dark blue type of the Belladonna. Blue Butterfly. An annual variety, with deep blue flowers. . .

White Butterfly. Annual variety

Cardinale. Large flowers of a brilliant scarlet color. Chinense Grandiflorum. Dwarf; blue.

Chinense Grandiflorum Album. Dwarf; white. Michell's Gold Medal Hybrids. A fine strain; long spikes of large flowers............ (1/1 lb., \$3.50)

Double Hybrids Mixed. A selected strain, with large double flowers. . 


\section{CALCEOLARIA}

A most decorative pot plant, which finds ready sale if well grown. The strains we offer cannot be excelled.

$1 / 2$ trade Trade Pkt. Pkt. Hybrida Grandiflora. Choice mixed $\left(\frac{1}{32}\right.$ oz., $\left.\$ 4.00\right) \$ 0.60 \quad \$ 1.00$ Hybrida Grandiflora Compacta. ( $\left(\frac{1}{32}\right.$ oz., $\left.\$ 4.00\right) \ldots .60 \quad 1.00$ Rugosa. Mixed colors.................... .60 1.00

\section{CAMPA NUA (Bell Flower)}

The taller sorts are splendid for cut flowers and most decora tive; the dwarf sorts make excellent border plants.

Carpatica Blue. Dwarf, 6 inches.

Trade pkt. Oz. Watifolia Macrantha. Large, purplis $\$ 0.25 \$ 1.00$ $.25 \$ 1.00$

Latifolia Macrantha. Large, purplish blue; 2 feet. Medium Calycanthema (Cup and Saucer). Blue.

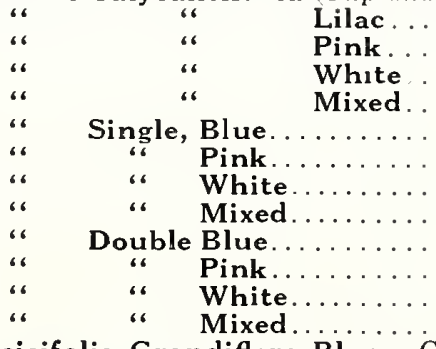

Persicifolia Grandiflora Blue. Grows 3 to 4 feet high and produces large bell-shaped flowers

Persicifolia Grandiflora Alba. White.

Pyramidalis (Chimney Bell Flower). Blue and white mixed; 4 to 6 feet.

\section{CANDYTUFT (Iberis)}

Splendid edging plants and also valuable for cutting. Trade pkt. Oz. Crimson..................

Empress. Large white. ( $1 / 2$ lb., $\$ 1.40 ; \$ 2.75$

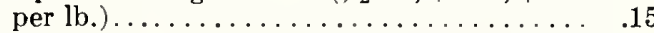

Lavender. (i) ib. $\$ 1.40) \quad .15$

Michell's Giant White. Immense spikes; a selected strain ( $1 / 2 \mathrm{lb} ., \$ 2.75 ; \$ 4.75$ per lb.) .20

Pink. Flesh color......... (1/2 lb., \$1.40) .15

Purple................. (1/2 lb., \$1.40) .15

Rose Cardinal. Rosy red .... (1/2 lb., \$2.25) $\quad .15$

Mixed. All colors............. (Lb., $\$ 2.00)$

Gibraltarica. Perennial; lilac shading to white. ........................... borders; flowers white.............. .40 $.40 \quad 2.50$

\section{CARNATION}

Indispensable for the greenhouse in Winter or the garden in Summer.

Trade pkt. Oz.

Chabaud's Everblooming, Jeane Dionis. White. $\$ 0.50 \$ 2.50$

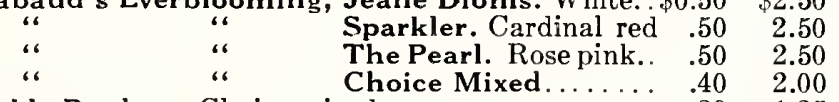

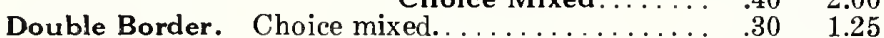

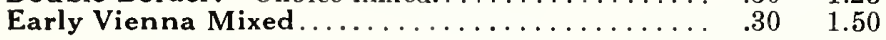

\section{CENTAUREA CYANUS (Cornfower)}

Very popular for cutting.

Double Blue. Splendid for forcing. Trade pkt. Oz.

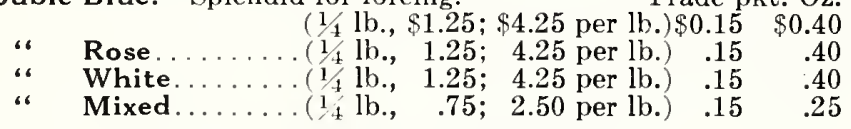

\section{CENTA UREA (Perennial)}

Montana (Hardy Cornflower). Violet blue...... .20

\section{CERASTIUM (Snow in Summer)}

Tomentosum. Dwarf perennial plant for edgings and rockeries; silvery foliage, white flowers

\section{CHEIRANTHUS}

Allionii (Siberian Wallfower). A biennial but best treated as an annual; spikes of brilliant orange flowers; very effective in the rockery . . . . . . . \$0.20

$\$ 0.60$

\section{CHELONE}

Hardy perennial; very showy bedding plant, fine for cutting.
Trade pkt. Oz.

Hybrida Torreyi. Brilliant scarlet..........\$0.30 $\$ 1.00$ Hybrida Mixed Various colors ............. $.30 \quad \begin{array}{r}\$ \\ 1.00\end{array}$

\section{CHRYSA NTHEMUM \\ (Perennial Varieties)}

Japonicum, Geisha. New single flowering mixed.

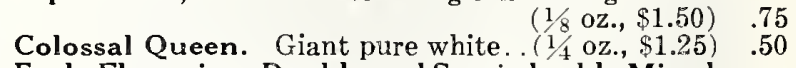

Early Flowering, Double and Semi-double Mixed.

Valuable for pot plants or cut flowers $\left(\frac{1}{16}\right.$ oz., $\left.\$ 1.50\right) \quad .50$

King Edward VII. Extra large; pure white....... .20

Shasta Daisy "Alaska." Pure white; extra large flowers; excellent for cutting..............

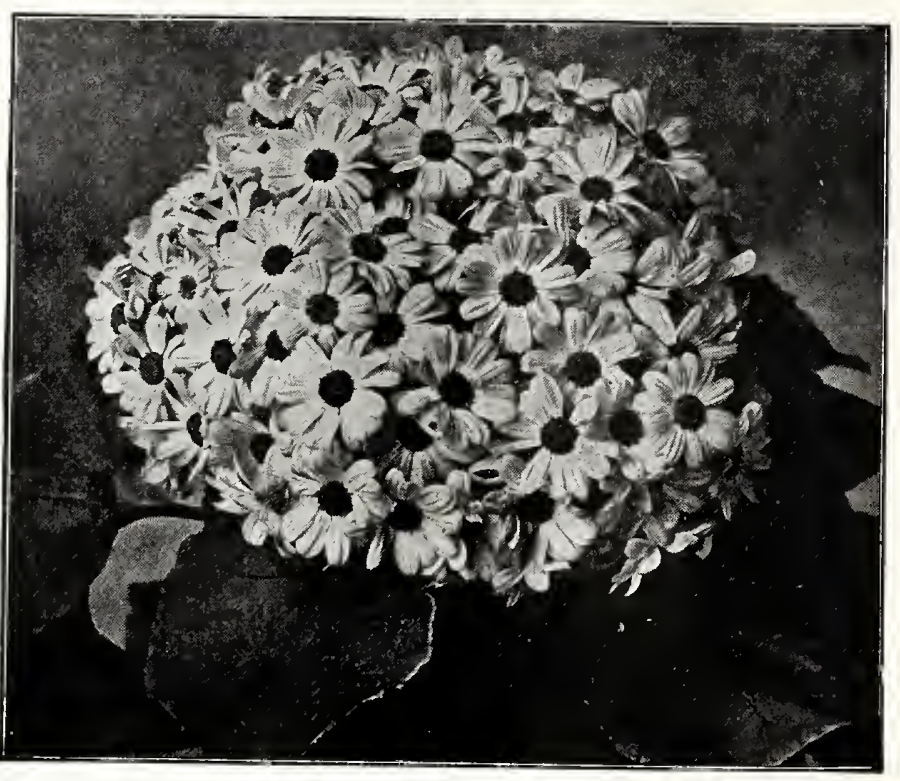

Cineraria, Multiflora Nana

\section{MICHELL'S“DISTINCTIVE”'CINERARIAS MULTIFLORA GRANDIFLORA MAXIMA}

A cross between Multiflora Nana and Grandiflora; flowers extra large and in a wonderful range of colors, individual florets measure 2 to 3 inches in diameter and produced in quantities of 100 blooms and over to the plant. This variety should prove a wonderful florists' proposition. We offer it in mixed colors only.

Half trade pkt., $\$ 1.00 ; \$ 1.75$ per trade pkt.; $\frac{1}{32} \mathrm{Oz} ., \$ 6.00$.

\section{CINERARIA, Multifiora Nana}

\section{(Potsdam and Berlin Market Strain)}

Very dwarf and compact; flowers of large size, produced in great profusion and in a range of the best colors and shades.

Azure Blue $1 / 2$ trade Trade

Dark Biue. Pkt. Pkt.

$\begin{array}{ccc}85 & 1.50\end{array}$

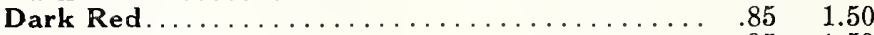

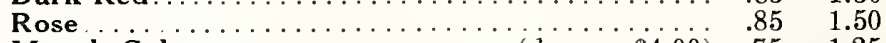

Mixed Colors...............

\section{CINERARIA, GRANDIFLORA PRIZE}

Our Grandiflora Prize Strain produces immense trusses of large flowers, often measuring 4 inches across. The Stellata varieties make exceedingly decorative pot plants. $\quad 1 / 2$ trade Trade

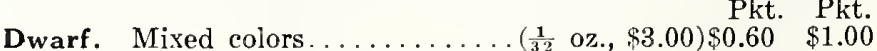
Medıum Tall. Mixed colors . . . . . . ( $\left(\frac{1}{32} \quad\right.$ oz., $\left.\$ 3.00\right) \quad .60 \quad 1.00$ Matador. Large flowering scarlet . . . . . . . . . $\quad .60 \quad 1.00$

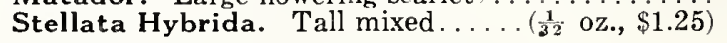




\section{MICHELL'S “DISTINCTIVE” FLOWER SEEDS}

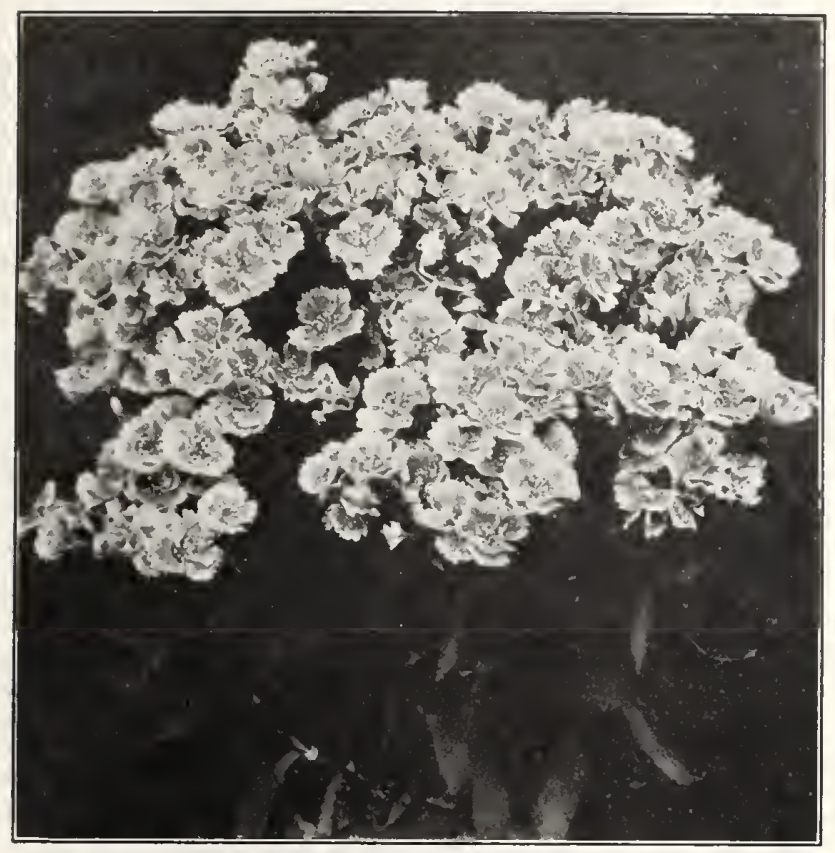

Dianthus, Sweet Wivelsfield

\section{DIANTHUS (PInks) \\ Sweet Wivelsfield}

A new annual hybrid variety; a cross between Dianthus Allwoodi and Sweet William. Distinct in habit and freedom of growth; blooms profusely in a great variation of colors; excellent for cutting. Trade pkt., $75 \mathrm{c}$.; $\$ 6.00$ per oz.

\section{DIANTHUS (Pinks \\ Hardy Garden Sorts}

Casius (Cheddar Pink). Masses of pink flowers;

Trade pkt. Oz.

splendid for the rock garden ..................... \$0 \$1.25

Clove Scented. Double and semi-double mixed ... $\quad .30 \quad 1.50$

Deltoides (Maiden Pink) Brilliant. Dwarf; brill-

iant carmine.............................. $50 \quad 3.00$

Double Scotch. Choice colors mixed .................. $30 \quad 1.50$

Latifolius Atrococcineus, f. pl. Double scarlet.. $\quad .25 \quad 1.00$

Pheasant's Eye. Single fringed flowers; mixed.... $\quad .15 \quad .50$

\section{DICTA MNUS (Gas Plant)}

Fraxinella. Perennial; purple red flowers.

\section{DIDISCUS}

Coeruleus (Blue Lace Flower). Easily grown annual with lavender blue lace-like flowers; excellent for cutting.

\section{DIGITALIS (Foxglove}

Gloxiniaeflora, Pink

“: $\quad$ Purple

Grandiflora. Light yellow.

Maculata Superba. A beautiful spotted variety

Monstrosa. Mammoth spikes, various colors

\section{DRA CENA}

Useful as centre plants for vases, baskets, etc. The seed is sent out in the hull or berry and should be rubbed out before sowing. Trade pkt. Oz. Australis. Broad leaves........... (1/4 Ib., \$2.25)\$0.20 $\$ 0.60$ Indivisa. Narrow green leaves; the popular centre plant for vases

\section{ECHINOPS Globe ThIstle)}

Ritro. Splendid hardy perennial, with thistle-like leaves and steel blue flowers.

\section{EDELWEISS (Leontopodium)}

Trade pkt.

Alpinum. A splendid perennial rock plant, with silvery white flowers............ (1/8 oz., $\$ 2.50) \$ 1.00$

\section{ERINUS}

Alpinus. A fine Spring blooming, perennial rock plant; mixed colors'. . . . . . . . . (1/8 oz., \$2.50) 1.00

\section{ERYNGIUM (Sea Holly}

An ornamental perennial plant, with round heads of flowers which can be cut and dried for Winter bouquets.

Amethystinum. Metallic blue flowers. Trade pkt. Oz. $\$ 0.50 \$ 3.00$

Planum. Small flower heads of pale blue.

\section{EUPATORIUM}

Fraseri. A fine perennial and useful for cutting; feathery white flowers

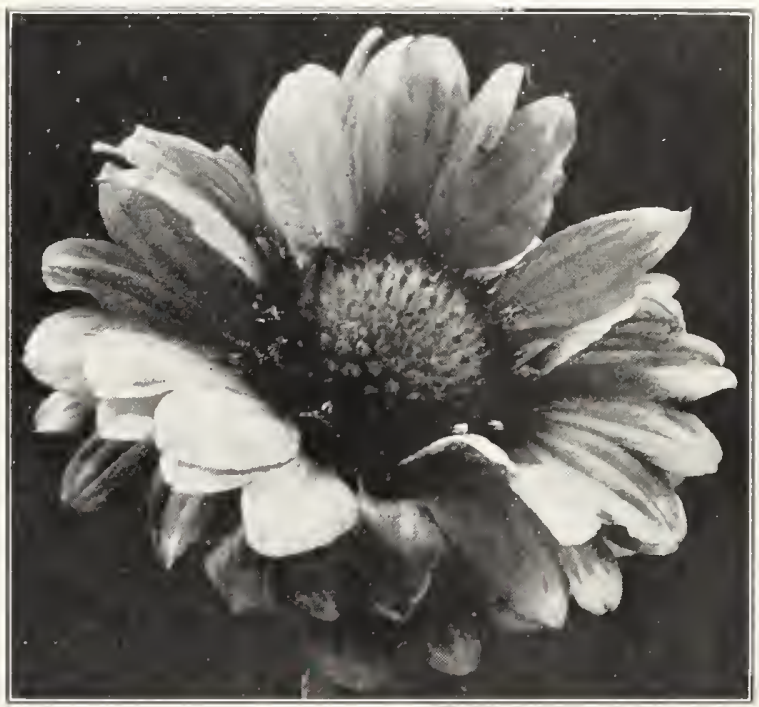

Gaillardia Grandiflora, Portola IIybrids

GAILLARDIA (Perennial Varieties

One of the showiest of hardy perennial plants; fine for cutting or borders.

Grandiflora Portola Hybrids. Bronzy red, golden tipped petals.

Trade pkt. Oz. 1/4 lb. Tangerine. Giant orange flowers, overlaid with red $(1 / 4 \mathrm{oz}$. $\$ 1.25$ )

“ Compacta. Mixed

" Sanguinea. Blood red

" Semi-Double. Mixed. Superba. Mixed. $0.50 \$ 3.00$

\section{$50 \quad 4.00$}

$.20 \quad .75 \quad \$ 2.50$

$\begin{array}{lll}20 & .75 & 2.50\end{array}$

$\begin{array}{lll}20 & .75 & 2.50\end{array}$

$.15 \quad .50 \quad 1.75$

\section{GENTIANA (Blue Gentian)}

Trade pkt. Oz.

Acaulis. Dwarf hardy perennial; deep blue flowers . $\$ 0.50 \$ 3.00$

\section{GERBERA Transvaal Daisy}

Splendid greenhouse perennials with large daisy-like flowers; fine for pot plants or for cutting.

Jamesoni Hybrida. These hybrids include many brilliant colors and shades. Per 100 seeds, 50c.; $\$ 4.00$ per 1000 seeds.

\section{GEU M}

Beautiful hardy perennials, bearing a profusion of large, showy, double flowers the entire summer.

Atrosanguineum Fl. Pl. Dark crimson.

Lady Stratheden. Golden yellow ..............50 3.50

Mrs. Bradshaw. Brilliant scarlet flowers............40 2.00 


\section{GLOXINIA}

Carefully saved seeds from perfect flowers and shapely plants.

Trade pkt.

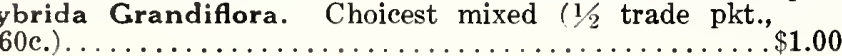

\section{GYPSOPHILA (Baby's Breath)}

Free flowering plants of easy culture, excellent for cutting to mix with other flowers.

Elegans Alba Grandiflora (True Paris Market

Strain). Annual variety; flowers pure white..... ( $1 / 4$ lb., 50c.; $\$ 1.50$ per lib.)

Elegans Carminea. Bright carmine rose ( $1 / 4 \mathrm{lb}, 60 \mathrm{c}$; $\$ 2.00$ per lb.)

Elegans Rosea. Delicate pink ( $1 / 4 \mathrm{lb} ., 60 \mathrm{c} ; \$ 2.00$

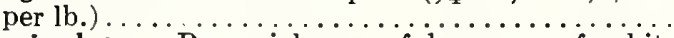

Paniculata. Perennial; graceful sprays of white

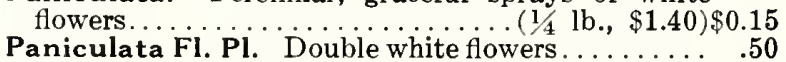

Repens. A pretty trailing perennial, with tiny white flowers; fine for the rock garden............ .25

Repens Rosea. Pinkish white flowers.............. $\quad 20$

\section{HELENIUM}

Autumnale Superbum. Perennial; large heads of golden yellow flowers.

\section{HELIOPSIS (Orange Sunfower)}

Pitcheriana. Perennial; deep golden yellow flowers; excellent for cutting ................... 15

\section{HEUCHERA}

Sanguinea (Coral Bells). Hardy perennial; spikes of vivid crimson flowers. Excellent for cutting...

.50

5.00

\section{HOLLYHOCK}

Our seed of this popular perennial plant is saved from extra fine double flowers and cannot be surpassed.

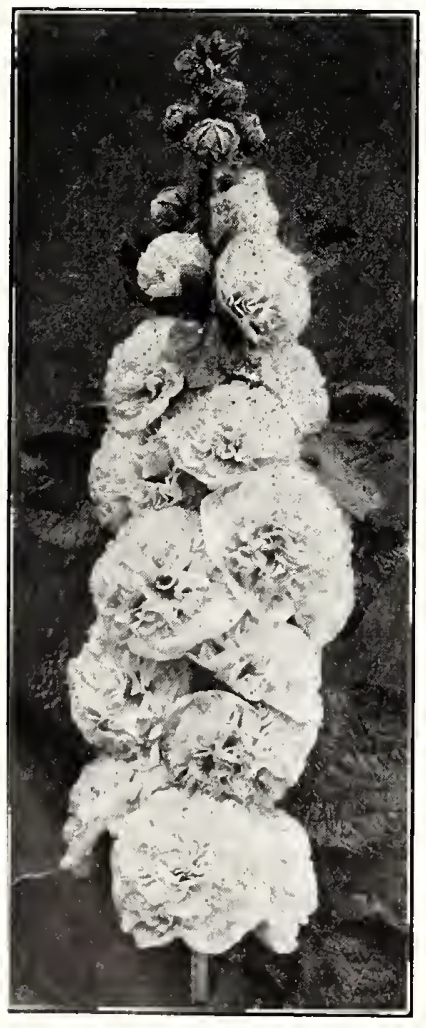

Hollyhock, Chater's Double
Allegheny. Semi-double fringed, mixed. Trade pkt., 25c.; $\$ 1.00$ per oz.; $1 / 4 \mathrm{lb}$., $\$ 3.75$.

Chater's Double Maroon. Trade pkt., 30c.; $\$ 1.25$ per oz.; $1 / 4$ lb., $\$ 4.50$.

Chater's Double Pink. Trade pkt., 30c.; $\$ 1.25$ per oz.; $1 / 4$ lb., $\$ 4.50$.

Chater's Double Red. Trade pkt., 30c.; $\$ 1.25$ per oz.; $1 / 4 \mathrm{lb}$., $\$ 4.50$.

Chater's Double Salmon. Trade pkt., 30c.; $\$ 1.25$ per oz.; $1 / 4$ lb., $\$ 4.50$.

Chater's Double White. Trade pkt., 30c.; $\$ 1.25$ per oz.; $1 / 4$ lb., $\$ 4.50$.

Chater's Double Yellow. Trade pkt., 30c.; $\$ 1.25$ per oz.; $1 / 4$ lb., $\$ 4.50$.

Chater's Double Mixed. Trade pkt., 25c.; $\$ 1.00$ per oz.; $1 / 4$ lb., $\$ 3.50$.

Double Newport Pink. Pure pink. Trade pkt., 30c.; $\$ 1.50$ per oz.; $1 / 4$ lb., $\$ 5.50$.

Double Everblooming Mixed. $1 / 4 \mathrm{lb} ., \$ 3.75$.

Single Mixed. Trade pkt., 20c.; $75 \mathrm{c}$. per oz.; $1 / 4 \mathrm{lb} ., \$ 2.50$. Trade pkt., 25c.; $\$ 1.00$ per oz.;

\section{HIBISCUS (Marshmallow)}

Trade pkt. Oz.

Crimson Eye. White with crimson centre....... $\$ 0.20 \$ \$ 0.60$

New Giant (Mallow Marvel). Mixed........... $.20 \quad .60$

IRIS (Flowering Flag)

Kaempferi (Japanese Iris). Mixed colors........ .15 .60

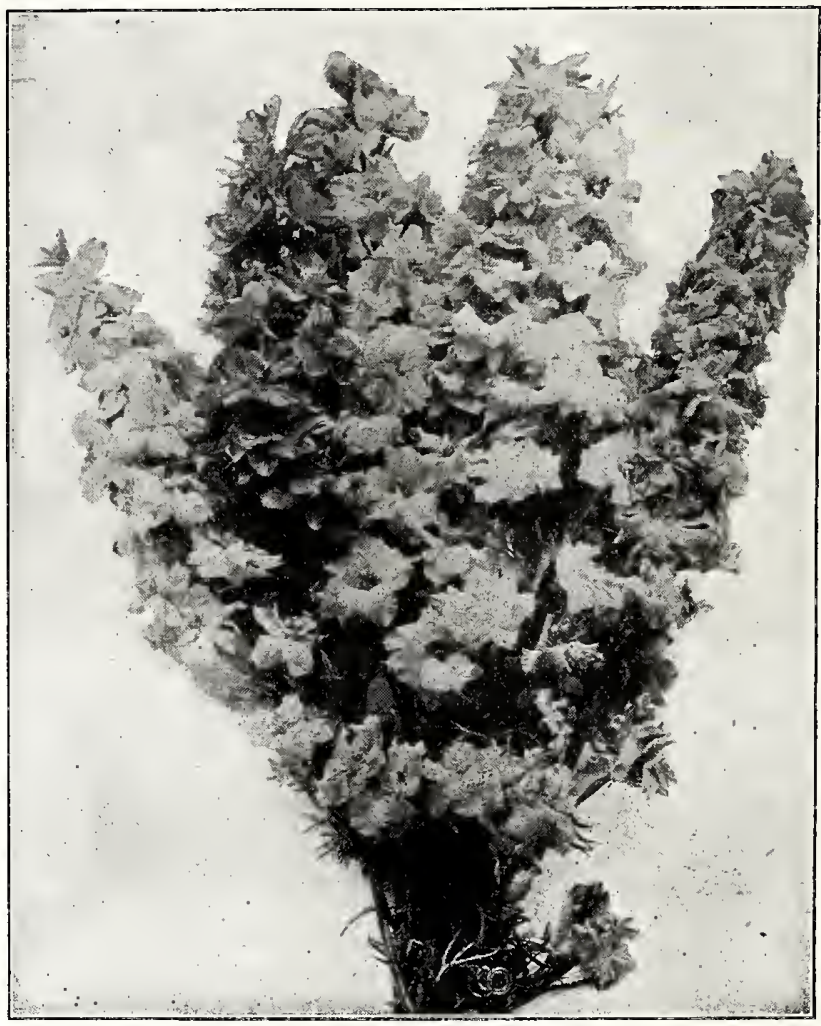

Larkspur, Double Tall Stock Flowered

\section{LARKSPUR (Annual)}

A very popular annual for cutting, either outdoors or in the greenhouse.

\section{GIANT IMPERIAL}

This new group of Larkspur is identical in branching habit to the Giant Imperial Stock; flowers very double; plants of robust habit of growth.

Blue Spire (Novelty). An intense deep Oxford blue....................\$0.50 \$3.00\$11.00

White Spire. Pure white ............ $.50 \quad 3.00 \quad 11.00$

Exquisite Pink, Improved. A splendid improvement over the old type; a beautiful salmon pink color; comes practically $100 \%$ true.

Exquisite Rose. A beautiful shade of rose

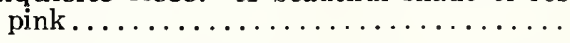

$\begin{array}{lll}.40 & 2.00 \quad 7.00\end{array}$

$\begin{array}{lll}.40 & 2.00 & 7.00\end{array}$

\section{TALL BRANCHING STOCK FLOWERED}

Los Angeles. A splendid new Stock Flowered

Trade pkt. Oz. $1 / 4 \mathrm{lb}$. variety; color rich salmon overlaid with brilliant rose.

$\$ 0.50 \quad \$ 3.00$

Dark Blue.................. (Lb., \$5.50) $.15 \quad .50 \quad \$ 1.75$

Exquisite. Soft pink . . . . . . . . . .

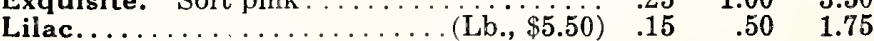

Lustrous Carmine. . . . . . . . . . . . (Lb., \$5.50) $\quad .15 \quad .50 \quad 1.75$

Shell Pink.................. (Lb., \$5.50) $\quad .15 \quad .50 \quad 1.75$

Sky Blue................... (Lb., $\$ 5.50) \quad .15 \quad .50 \quad 1.75$

White........................ \$5.50) $\quad .15 \quad .50 \quad 1.75$

Mixed.......................... $\$ 4.00) \quad .15 \quad .40 \quad 1.25$

Emperor, Pink Delight. Soft, bright rose pink; dwarf and compact............. $.30 \quad 1.25 \quad 4.00$ Giant Hyacinth Flowered. 'Mixed...... 
LATHYRUS LATIFOLIUS (Perennial Pea

Showy, hardy perennial climbers; excellent for cutting.

Crimson...

Pink Beauty. Bright pink

White.......................

Trade pkt. Oz.

\section{LAVENDER}

Lavendula Vera (True). Fragrant blue flowers.

\section{LIATRIS (Blazing Star)}

Pycnostachya. A showy perennial border plant; rosy purple flowers; excellent for cutting. .

\section{LILY}

Regale (Lil. Myriophyllum). Perfectly hardy; excellent for forcing; flowers waxy white.

\section{LINUM (FIax)}

Perenne. Perennial; large blue flowers

\section{LOBELIA}

Cardinalis (Cardinal Flower). Stately perennial plants with spikes of cardinal red flowers.........

\section{LUPINUS (Annuai)}

Very attractive and popular as a cut flower.

Pink.

Trade pkt. $\mathrm{Oz}$.

Rich Blue

$\$ 0.15 \$ 0.25$

Sky Blue

.15
.15
.15

.15

\section{.25}

White.

$.15 \quad .25$

\section{LUPINUS - Perennial Varieties}

Polyphyllus Blue.

Trade pkt. Oz.

$$
\text { “، }
$$

Moerheimi. Pink and white

Roseus. Soft pink.

Mixed. All colors.

New Hybrids Mixed

(i $1 / 4 \mathrm{lb} ., 75 \mathrm{c}$.

\section{LYCHNIS}

Hardy perennial plants of easy culture.

Arkwrightii. Splendid new hybrids; free flowering . Chalcedonica. Scarlet cross-like flowers; 2 feet.. Haageana Hybrida. Mixed; various colors; 1 foot. Viscaria Splendens. Bright rose red; fine for the rockery.

\section{LYTHRUM}

Roseum Superbum. A fine hardy perennial; rosy pink flowers in July; 3 feet.

\section{MATRICARIA (Feverfew)}

Double White. Fine for cut flowers ...........
Golden Ball. Dense habit; bright yellow flowers

$\begin{array}{rr}.40 & 2.00 \\ .15 & .50 \\ .40 & 2.00 \\ & \\ .15 & .60\end{array}$

\section{GNONETTE}

Valuable for cutting on account of its fragrance. Michell's Colossal. One of the finest sorts for forcing. Colossal spikes from 18 to 24 inches high. .

\section{MYOSOTIS (Forget-Me-Not)}

Alpestris Victoria. Bright blue; dwarf.......... Eliza Fanrobert. Clear blue; fine for pots..........

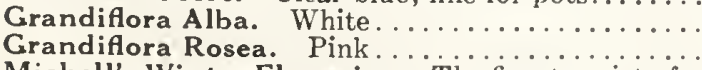

Michell's Winter Flowering. "The finest variety for forcing; long stems; large deep blue flowers..

Palustris Semperflorens. Everblooming, blue..

Choice Mixed

\section{NEPETA}

Mussini. A favorite perennial rock plant; blue gray foliage and pale mauve flowers

$.15 \quad .50$

$.50 \quad 3.00$

3.50

2.00
$\$ 0.20 \$ 0.75$

$\begin{array}{rr}.25 & 1.00 \\ .20 & .75\end{array}$

$.15 \quad 60$

.75

3.50

2.50

7.00

$1 / 4 \mathrm{lb}$. Lb.

$\$ 0.75 \$ 2.75$

$.75 \quad 2.75$

$.75 \quad 2.75$

$\begin{array}{ll}75 & 2.75 \\ -65 & 2.40\end{array}$

. $\$ 0.15 \$ 0.25$

.30

.20

.15

.15

\section{OENOTHERA (Evening Primrose}

Trade pkt. Oz.

Beautiful hardy perennial plants; free flowering.

Missouriensis. A prostrate growing variety; bright

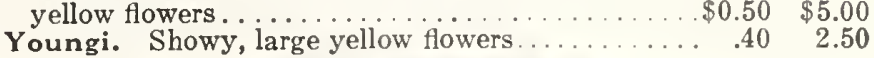

$\$ 0.50 \quad \$ 5.00$

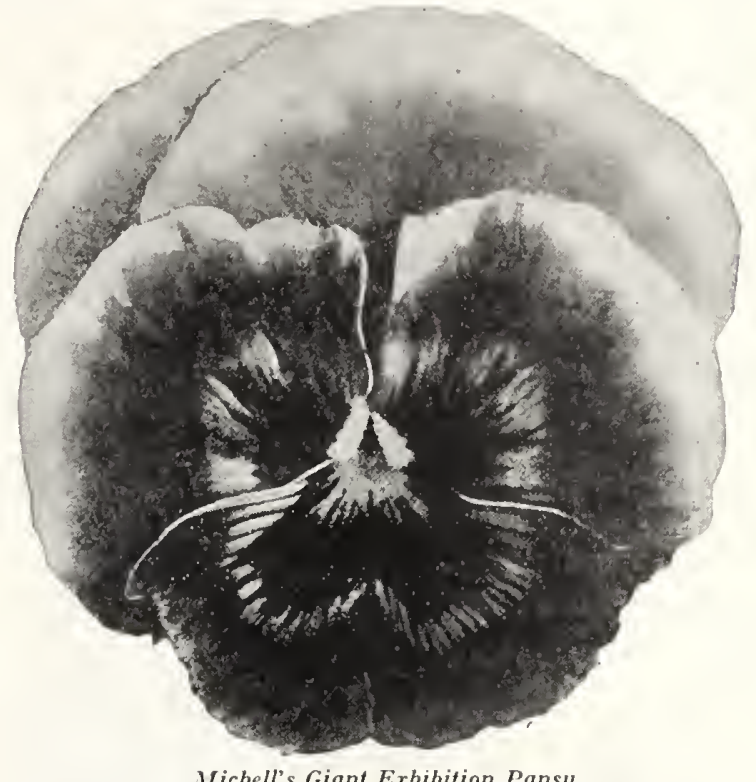

MICHELL'S GIANT PANSIES

Our strains of this popular flower are procured from the leading Pansy specialists and cannot be surpassed for size and form, beautiful markings and brilliancy of colors and shadings.

GIANT STRAIN IN SEPARATE COLORS

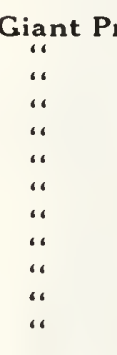

\section{Trade pkt. Oz.}

$1 / 4 \mathrm{lb}$. ".ize Azure Blue
Black Blue.

“ Emperor William. Plue.

“ Hortensia Red.

" King of the Blacks. .

“ Lord Beaconsfield.

“ Peacock. Blue, claret and white

“ Snow Queen. Pure white

“ White with Eye.

“ Pure Yellow.

“ Yellow with Eye.

" Orange King. Orange with creamy tint ( $1 / 2$ trade pkt., $30 \mathrm{c}$.).

. $\$$

$\begin{array}{rr}.30 & \$ 1.50 \\ .30 & 1.50\end{array}$

$\begin{array}{ll}.30 & 1.50 \\ .30 & 1.50\end{array}$

$30 \quad 1.50$

$30 \quad 1.50$

$30 \quad 1.50$

$30 \quad 1.50$

$.30 \quad 1.50$

$30 \quad 1.50$

$.30 \quad 1.50$

$.30 \quad 1.50$

$\$ 5.50$

5.50
5.50

5.50

5.50

5.50

5.50

5.50

5.50

5.50

5.50
Michell's Giant Exhibition, Mixed. A giant strain which for size of bloom, heavy texture and varied shades and colors, with their distinct markings, cannot be excelled. 30c. per $1 / 2$ trade pkt.; trade pkt., 50c.; $\$ 1.00$ per $1 / 8$ oz.; $1 / 4$ oz., $\$ 1.75 ; \$ 6.50$ per oz.; $1 / 4$ lb., $\$ 24.00$.

Triumph of the Giants, Mixed. Produces on long stems flowers of immense size; many beautiful, rich and rare shades. $60 \mathrm{c}$. per $1 / 2$ trade pkt.; trade pkt., $\$ 1.00 ; \$ 2.25$ per $1 / 4 \mathrm{oz}$; per oz., $\$ 8.00 ; \$ 30.00$ per $1 / 4 \mathrm{lb}$.

Oregon Giants $(N e w)$. Super giant flowers beautifully marked in a myriad of bright colors; free flowering. Trade pkt., $\$ 1.00$; $\$ 2.50$ per $1 / 8$ oz.; $1 / 4$ oz., $\$ 4.50 ; \$ 15.00$ per oz.

Roggli Giant (Swiss Pansy). (New.) Flowers of enormous size and with overlapping petals; many brilliant colors and shades, making a wonderful combination. Excellent for greenhouse culture. Trade pkt., $75 \mathrm{c} ; \$ 1.50$ per $1 / 8 \mathrm{oz} ., 1 / 4 \mathrm{oz}$., $\$ 2.50 ; \$ 9.00$ per oz. $\quad$ Trade pkt. Oz. $1 / 4 \mathrm{lb}$.

Giant Trimardeau Mixed. Very large flowering in a good range of colors ........ \$0.25 $\$ 1.50 \quad \$ 5.50$

Giant Yellow Shades. A selected mixture. . .50 5.00

Mad. Perret. Especially rich in red shades; flowers are of large size and borne freely.

Masterpiece (Frilled Pansy). Beautiful rich colors; petals curled or waved.

$50 \quad 3.00 \quad 11.00$ $\begin{array}{lllllll}50 & 6.00 & \text { Finest English Mixed. Large flowering } & .25 & 1.25 & 4.50\end{array}$ 


\section{PENTSTEMON}

Sensation. Largely used for bedding; should be

Trade pkt. Oz. treated the same as Petunias, Verbenas, etc.; mixed colors

New Hybrids Mixed. Hardy perennial; large spikes $\$ 0.50$

\section{PHL OX (Hardy)}

Decussata. Choice mixed

PHYSALIS (Chinese Lantern Plant)

Francheti. Perennial: orange scarlet fruits...... .20

\section{PHYSOSTEGIA}

Perennial border plant; tubular flowers.

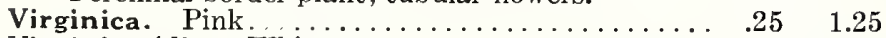

Virginica Alba. White................ $.25 \quad 1.25$

\section{PLATYCODON (Japanese Balioon Flower)}

A very desirable perennial; excellent for the permanent border or among shrubbery.

Grandiflorum. Blue.

Trade pkt. Oz.

Grandiflorum Alba.

$\$ 0.30 \$ 1.50$

\section{POLYANTHUS (Primula Elatior)}

Gold Laced. Very showy . . . . . . . (1/4 oz., \$2.00) $\quad .50$

English. Single mixed ............... .40

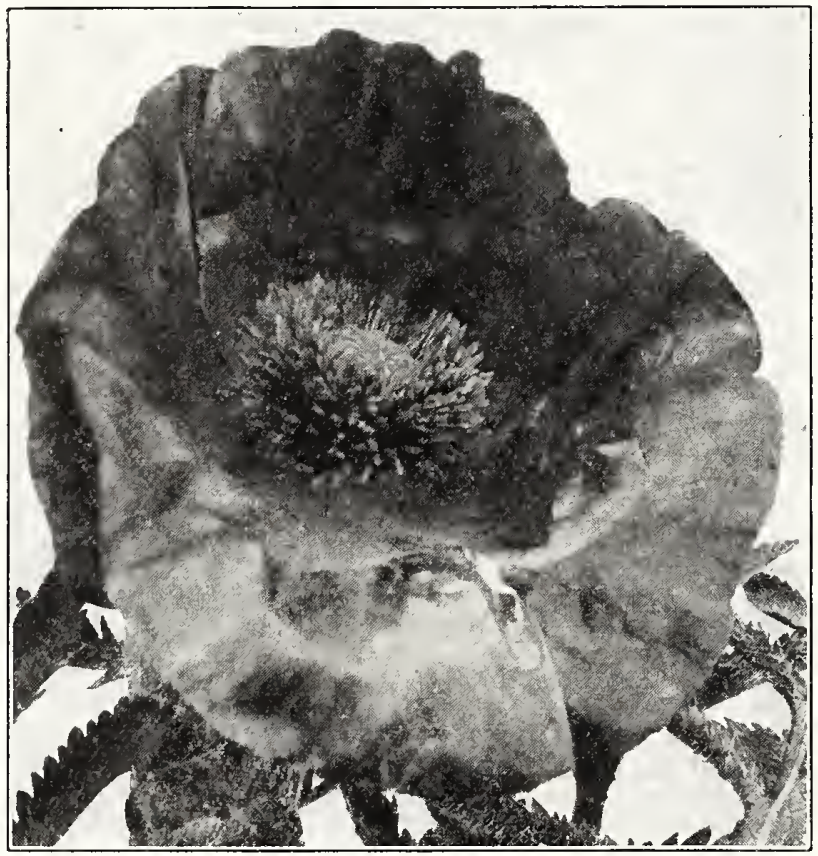

Oriental Poppy

\section{POPPY-PERENNIAL VARIETIES}

Iceland (Nudicaule) El Monte (Novelty). Very large

Trade pkt. Oz. flowering; comes true from seed; fine for cutting;

color, tangerine orange ................. $\$ 0.75$

Iceland, Orange Scarlet..........................

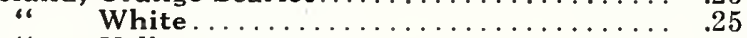

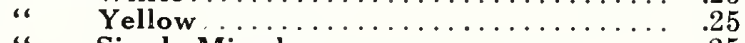

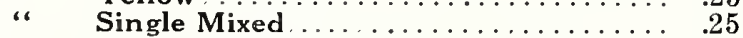

“ Sunbeam. Splendid mixed hybrids . . . . . . .40

Orientale. Deep scarlet . . . . . . . . . . . . . . . . . 20

“ Mrs. Perry. Rich salmon pink........ $\quad .40$

$\begin{array}{llll}\text { Mrs. Perry } & \text { Rich salmon pink........ } & .40 & 2.50 \\ \text { Hybrids. Mixed colors.............. } & .25 & 1.00\end{array}$

\section{POTENTILLA}

Single Mixed. A most effective perennial rock plant, the flowers resembling Geum.............\$0.15

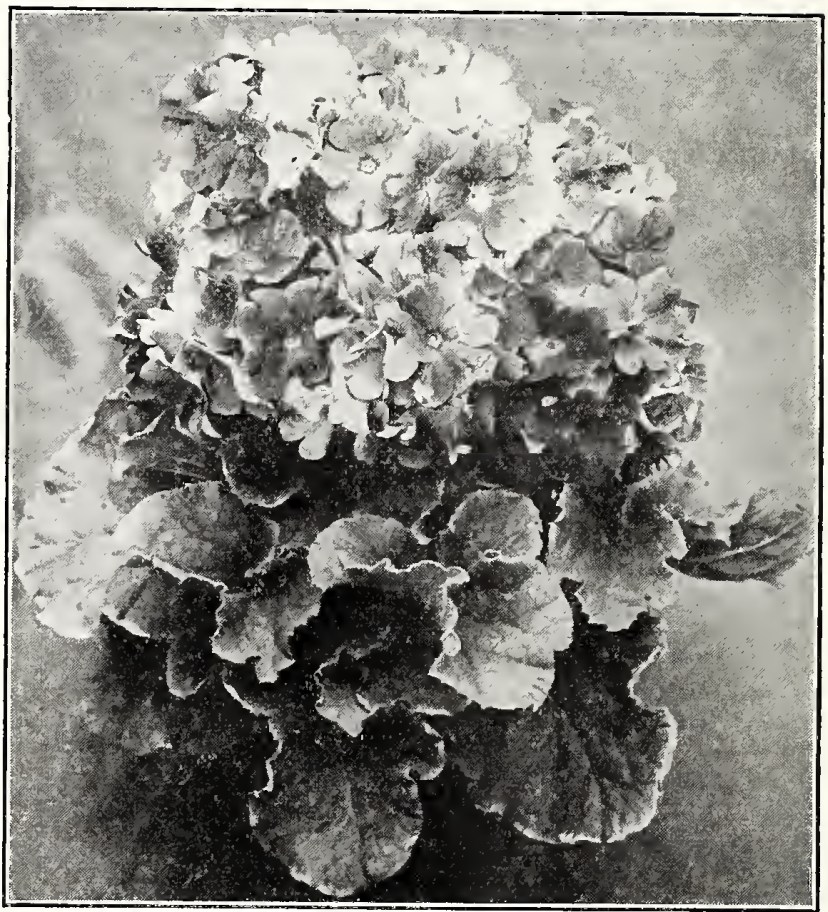

Primula Obconica, Fasbender

\section{MICHELL'S PRIMULAS}

\section{FRINGED CHINESE VARIETIES}

We have a superb strain, grown for us by the best specialists in Europe. Plants are compact, individual and clusters of flowers immense; elegantly fringed flowers.

$1 / 2$ trade Trade

Michell's Prize Mixture. This mixture contains

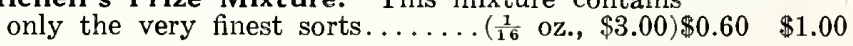

\section{PRIMULA OBCONICA}

These are splendid pot plants for winter blooming.

Fasbender (Novelty). Very compact growth; giant flowers; color, deep crimson. 500 seeds, $\$ 1.25$; $\$ 2.00$ per 1000 seeds; 5000 seeds, $\$ 9.00 ; \$ 17.00$ per 10,000 seeds.

Mueller and Mohnstein Mixed. Shades of pink and red. Trade pkt. (1000 seeds), $\$ 1.00 ; 10,000$ seeds or over, $85 \mathrm{c}$. per 1000 seeds.

Gigantea MONSTER. A large flowering strain. Trade pkt. “ Apple Blossom. Soft pink.............\$1.00

“ Kermesina. Deep crimson................ 1.00

“ Deep Rose. Brilliant color.................. 1.00

“ Rose Queen. Clear rose pink of large size..... 1.25

“ Rosea. Pink..................... 1.00

“ Salmon Queen.................... 1.00

“ Mixed Colors.................... 1.00

PRIMULA, VARIOUS SORTS

Japonica (Hardy Japan Primrose). Mixed . . . (Oz., \$3.50) Kewensis (Verbena Scented Yellow Primrose). Long spikes of yellow flowers . . . . . . . . . . . . . . (1 oz., \$1.25) Malacoides (Improved Baby Primrose). Color, light lilac.
$\$ 4.00$

1.00

1.00
1.00

1.00

2.50

.75

00

(1)

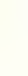

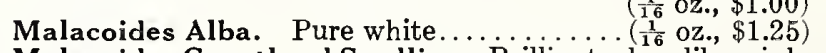

Malacoides Courtland Seedling. Brilliant, clear lilac pink;

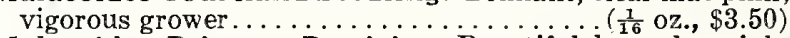
Malacoides Princess Patricia. Beautiful lavender pink,

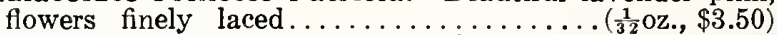

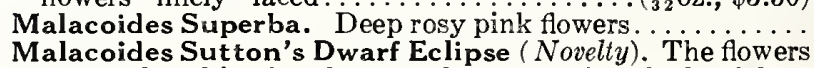
are produced in abundance and of a pleasing shade of deep lavender pink, and are much larger than any other variety of this class...................... $\left(\frac{1}{32} \mathrm{Oz} ., \$ 5.00\right) 1.00$

Veris (Cowslip). Mixed ........................ \$2.50) $\quad .40$

Vulgaris (English Yellow Primrose) .............(Oz., \$2.50) $\quad .40$ 


\section{MICHELL'S “DISTINCTIVE” FLOWER SEEDS}

\section{PYRETHRUM (Perennial)}

Roseum. Pink..................... \$0.40 \$2.00

Uliginosum (Giant White Daisy) ................ $40 \quad 2.00$

Hybridum. Single mixed................. .30 1.50

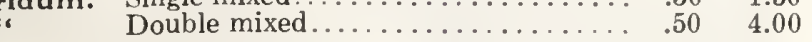

RUDBECKIA (Cone Flower)

Tall growing plants, flowering profusely all summer.
Newmani. Yellow with purple cone: perennial......
Purpurea (Giant Purple Cone Flower). Reddish

purple with large brown center; perennial....... .2

\section{SALVIA}

Patens. Perennial; rich deep blue ( $1 / 2$ trade pkt., 40c.)

\section{SAPONARIA}

Ocymoides. Splendid hardy plants for the rockery

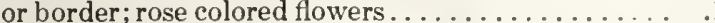

\section{SAXIFRA GA}

Decipien Hybrids Mixed. A charming little perennial plant; excellent for the rockery ....

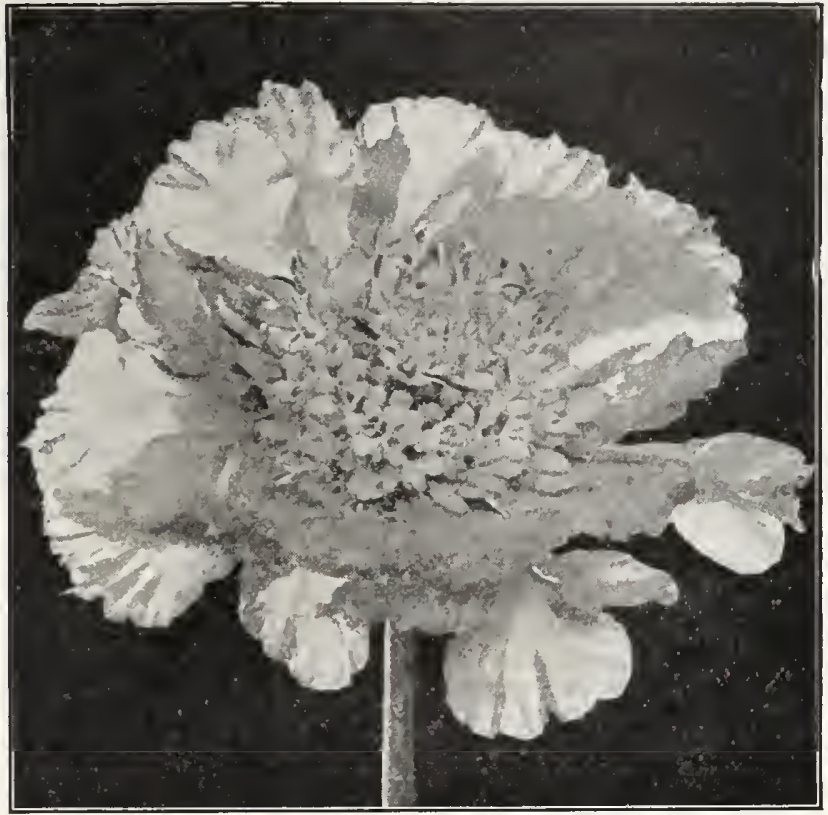

Scabiosa Caucasica, Giant IIybrid

\section{SCABIOSA}

Caucasica. Perennial; light blue.

Alba White. Colors range from light lavender to dark blue.

Columbaria Anthemifolia. A low growing variety;

large flowers of a delicate shade of pink. . .

Japonica. Perennial; lavender blue flowers.

\section{SCHIZANTHUS (Butterfiy Flower)}

Garraway's Hybrids. A beautiful strain for greenhouse, containing a wide range of colors .......... . .
Hybridus Grandiflorus. Dwarf; mixed colors . . . .

Wisetonensis. Various colors; fine for pots....... . .30

\section{SEDUM (Stonecrop)} the rock garden; perennial........(1// Oz., \$1.50) .75

\section{SI DALCEA}

Rosy Gem. A handsome perennial; spikes of rosy pink flowers.

STATICE (Everlasting Flower)

Free flowering plants; valuable for cutting or decoration, either when fresh or in their dried state. Incana Hybrida. Perennial; dwarf. Trade pkt. Oz. Latifolia. Perennial; large deep blue flowers.
Giant Hybrids (Isaac House Strain)

Acre. The well known yellow variety; very useful in

1.00 rade pkt. Oz. $.50 \$ 3.00$ $50 \quad 3.00$

$.75 \quad 5.00$ $75 \quad 5.00$ $5 \quad .60$

3.00 .75 1.50

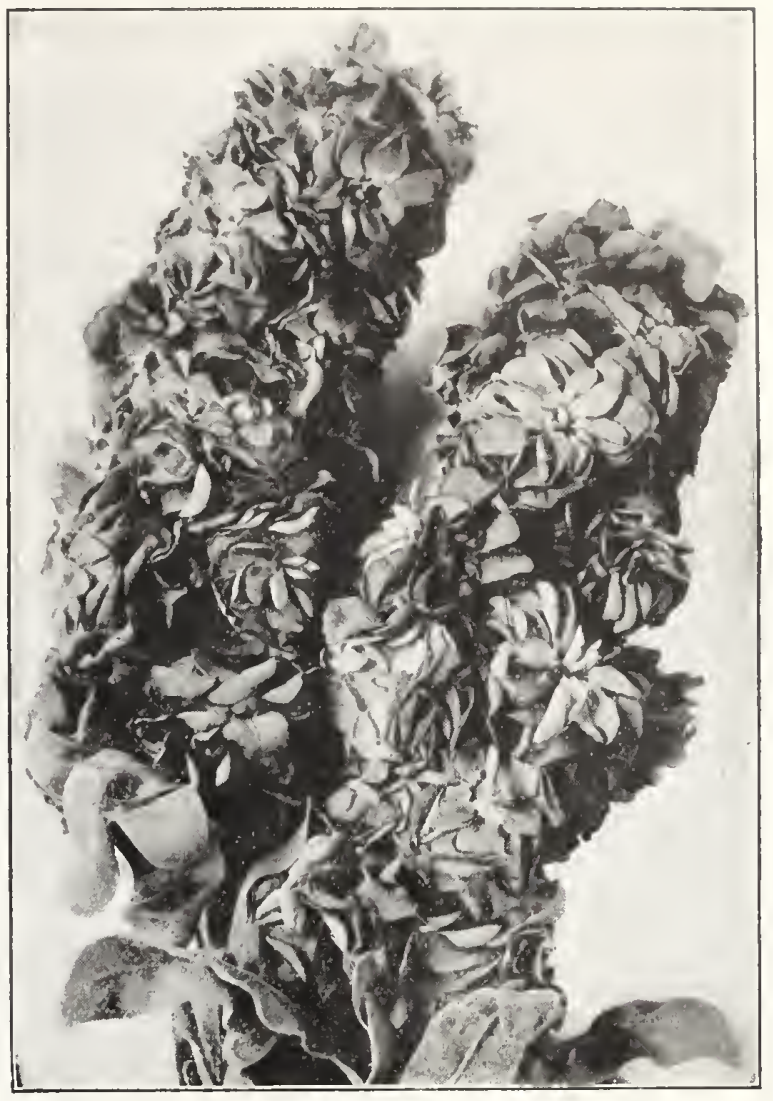

Stock, Early Giant Imperial, Elk's Pride

\section{Michell's "Distinctive" Stocks}

Stocks are one of the most profitable flowers to raise, provided you sow the right strains. For years we have made a specialtylof supplying "Distinctive" strains, which are easily distinguished by their superior quality, strong germination and a remarkably small percentage of single flowers.

\section{EARLY GIANT IMPERIAL}

\section{(Improved Bismarck)}

A splendid addition to the early forcing class; of tall branching habit, 24 to 30 inches high; immense spikes of large double flowers: especially valuable for indoor culture, for cutting.

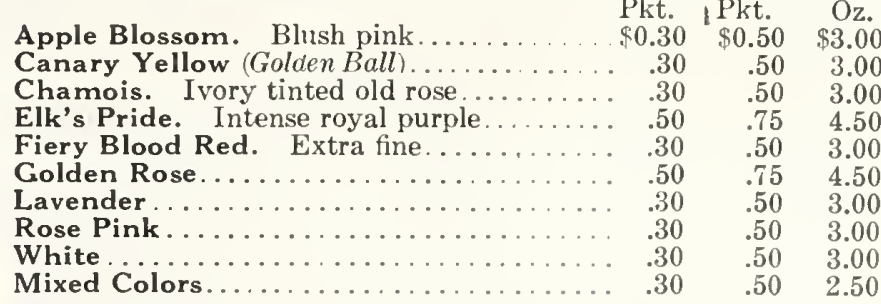

\section{CHELL'S EARLY FLOWERING "NICE"}

A branching stock literally covered with blooms, which appear earlier than in any other strain.

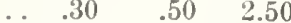
Midsummer Night. Deep dark violet. . . . $\quad .30 \quad .50-2.50$ Mont Blanc. Pure white.............. $\quad .30 \quad .50 \quad 2.50$ Monte Carlo. Canary yellow .... $\begin{array}{rrr}30 & .50 & 2.50\end{array}$ Old Rose. Extra fine................ $.30 \quad .50 \quad 2.50$ Queen Alexandra. Delicate lavender..... $\quad .30 \quad .50 \quad 2.50$ Choice Mixed. All colors............. $\quad .30 \quad .50 \quad 2.00$ CUT AND COME AGAIN

Princess Alice. Pure white............... $.30 \quad .50 \quad 2.50$ 


\section{NOVELTIES}

The following varieties just introduced have proven to be a great improvement in the Winter-flowering Spencer Sweet Peas. They are of special merit as regards size and form of flowers and length of stem.

Fascination. A wonderful new early flowering variety, with the salmon rosepink color of the famous late Hawlmark Pink, plus the long, strong stem of the early Jeanne Mamitsch .............

Satin Rose. A vigorous, large flowering, early variety; color is an exquisite blend of rose and amber, with a touch of salmon. 2.25

Oz. $\quad 1 / 4$ lb. Lb. $\$ 2.25 \$ 7.50 \quad \$ 25.00$

Lady Gay. A delightful shade of soft shrimp Oz. pink, one of the best of the newer early flowering varieties.

Peaches. A magnificent variety with extra long stems; produces four large blooms to a stem; color a new shade of bright apricot rose, with a touch of lemon in the keel.... 2.25

\section{$\$ 2.25 \$ 7.50 \$ 25.00$}

$7.50 \quad 25.00$

\section{OF RECENT INTRODUCTION}

Blue Bonnet. Color, a fine deep blue, evenly distributed, without the slightest trace of mauve; long stems with four blossoms to a stem. The finest black seeded, pure white to date; flowers are of mammoth size, well waved and produced on long stems......

Majestic Rose. Color, deep brilliant rose pink, which is more evenly diffused than in any other variety in this color class.

Michell's Rose Wonder. A beautiful clear, sparkling rose-pink color on a light ground. Very brilliant under artificial light; flowers are immense.

Oz. $1 / 4 \mathrm{lb}$.

7.50

25.00

Valencia. A bright orange in color and absolutely sun-proof; stems long and producing

3 and 4 large flowers to each stem.

\section{GENERAL LIST}

Aviator. Flowers extra large; color, dazzling crimson scarlet. ................. $\$ 0$.

Ball's Blue. Fine form; clear even blue......
Ball's Orange. Intensive clear glowing orange

Ball's Rose. Sparkling shade of deep rose.

Blue Bird. A charming shade of blue......

Burpee's Orange. Clear glistening orange.

Charm. Color, rich rose pink shading to a lighter tone; a light suffusion of salmon is noticeable overlaying the standard.........

Chevalier. Rose color with slight yellow tinge toward the base; extra large.......... Columbia. Salmon color standard; white

Eldorado. Pure orange salmon ....
Flamingo. Standard orange and salmon, wings orange-pink.

Florence Michell. An extra fine deep blue.;
Giant Rose. A large improved Zvolanek's rose color; an extra fine variety.

Gleam. Best described as bright geraniumpink or soft salmon-cerise. Flowers large, frilled and borne on long stems

Glitters (Early Royal Scot). Standard bright fiery orange; wings deep orange

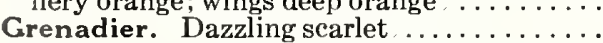

Harmony. A beautiful clear lavender.

Heather Bell. Rich, mauve lavender

Jeanne Mamitsch. Flowers large, on long stems; color, a beautiful shade of rose pink.

Lavender King. Rich, true deep lavender throughout; of large size and well waved
$\$ 0.75 \quad \$ 2.50 \quad \$ 8.00$

$\begin{array}{lll}1.00 & 3.50 & 12.00\end{array}$

$\begin{array}{lll}.75 & 2.50 & 8.00\end{array}$

$\begin{array}{lll}1.50 & 5.00 & 15.00\end{array}$

$\begin{array}{lll}1.00 & 3.50 & 12.00\end{array}$

Oz. $\quad 1 / 4 \mathrm{lb}$. Lb.

$0.50 \quad \$ 1.50 \quad \$ 5.00$

$\begin{array}{lll}.50 & 1.50 & \mathbf{5 . 5 0}\end{array}$

1.50
1.50

$1.50 \quad 5.00$

$\begin{array}{lll}.50 & 1.75 & 6.00\end{array}$

$\begin{array}{lll}.50 & 1.50 & 5.00\end{array}$

$\begin{array}{lll}.50 & 1.50 \quad 5.00\end{array}$

$\begin{array}{lll}.50 & 1.50 & 5.00\end{array}$

$\begin{array}{lll}.60 & 1.75 & 6.00\end{array}$

$\begin{array}{lll}.50 & 1.50 & 5.00\end{array}$

$\begin{array}{lll}.75 & 2.50 & 8.00\end{array}$

$\begin{array}{lll}.50 & 1.50 & 5.00\end{array}$

$50-1.50+5.00$

$\begin{array}{lll}.50 & 1.50 \quad 5.00\end{array}$

$\begin{array}{lll}50 & 1.50 & 5.00\end{array}$

$\begin{array}{lll}.50 & 1.50 & 5.00 \\ .60 & 1.75 & 6.00\end{array}$

$\begin{array}{lll}50 & 1.50 & 5.00\end{array}$

$\begin{array}{lll}.50 & 1.50 \quad 5.00\end{array}$

$\begin{array}{lll}.50 & 1.50 \quad 5.00\end{array}$
$1.50 \quad 5.50$

$\begin{array}{lll}.50 & 1.50 & 5.00\end{array}$

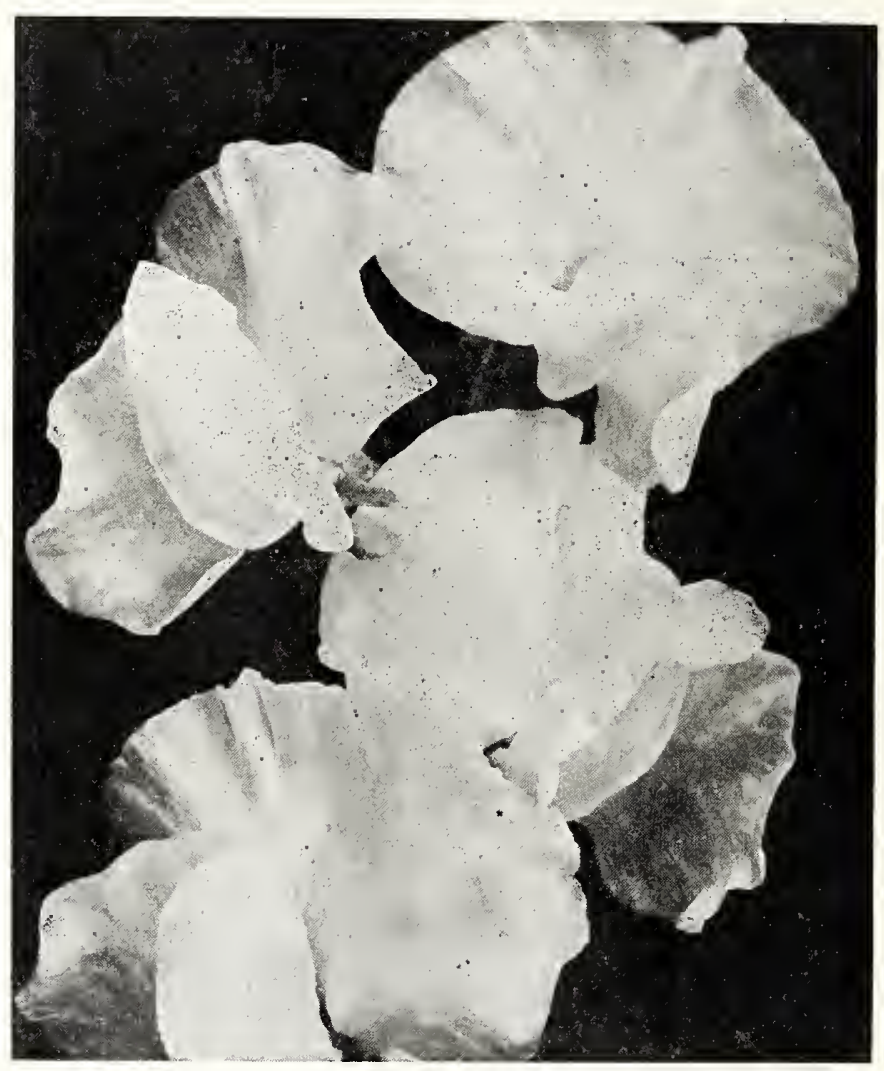

Sweet Pea, White Harmony

Madonna. Giant white; black seeded.... Oz. 1/4 lb. Lb.

Morse's Superior Pink. A beautiful rose pink, slightly shaded saimon......

Flowers are clear blue, which shade will undoubtedly be appreciated by all flower growers; stems very long. ..............

Mrs. Kerr. Rich salmon and orange..

Pink Profusion. A sparkling shade of rich pink; flowers large.

Rose Dore. A beautiful rose pink, suffused gold, orange shading; long stems, carrying three and often four well placed flowers. .

Rose Queen. The flowers are borne on long stems, are of large size and free bloomers; usually four flowers are produced on a stem; color, a most attractive shade of rose pink. Greenhouse grown seed....

Outdoor grown seed................ early flowering white Sweet Peas to date.

White Harmony. A black seeded variety. Stems are long, flowers large, pure paper white and of grand substance .......... Yarrawa. Flowers exquisitely waved, of
large size. Color, a pleasing shade of bright rose pink with lighter wings........... Zvolanek's Rose. Rose pink. . . . . . . . . . . Mixed. Winter Flowering Spencer......... $.50 \quad 1.50$

5.00

$\begin{array}{lll}.50 & 1.50 & 5.00\end{array}$

$\begin{array}{lll}.75 & 2.50 & 8.00\end{array}$

$\begin{array}{lll}.50 & 1.50 & 5.00\end{array}$

$\begin{array}{lll}.50 & 1.50 \quad 5.00\end{array}$

$\begin{array}{lll}.50 & 1.50 \quad 5.00\end{array}$

$\begin{array}{lll}1.00 & 3.50 & 12.00\end{array}$

$\begin{array}{rrr}.50 & 1.50 & 5.00\end{array}$

$\begin{array}{lll}.50 & 1.50 & 5.00\end{array}$

$\begin{array}{lll}.75 & 2.50 & 8.00\end{array}$

$\begin{array}{lll}.50 & 1.50 & 5.00\end{array}$

$\begin{array}{lll}.50 & 1.50 & 5.00\end{array}$

$\begin{array}{lll}30 & 1.00 & 3.00\end{array}$

\section{MICHELL'S SPENCER OR ORCHID SWEET PEAS SUMMER FLOWERING}

Superb Mixture. Blended from only the Giant Waved Spencer varieties, including a number of new hybrids of exquisite colors and shades. Per oz., 15c.; 40c. per $1 / 4 \mathrm{lb}$; lb., $\$ 1.30 ; \$ 12.00$ per $10 \mathrm{lbs}$. 


\section{MICHELL'S “DISTINCTIVE” FLOWER SEEDS}

\section{STOKESIA (Cornflower Aster)}

One of the most desirable hardy perennial plants for the border and excellent for cutting.

Cyanea. Lavender blue. Trade pkt. Oz.

\section{SWEET ROCKET (Hesperis)} $\$ 0.40 \$ 2.50$

Trade pkt. Oz.

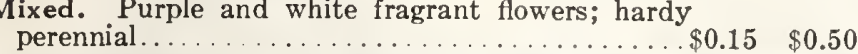

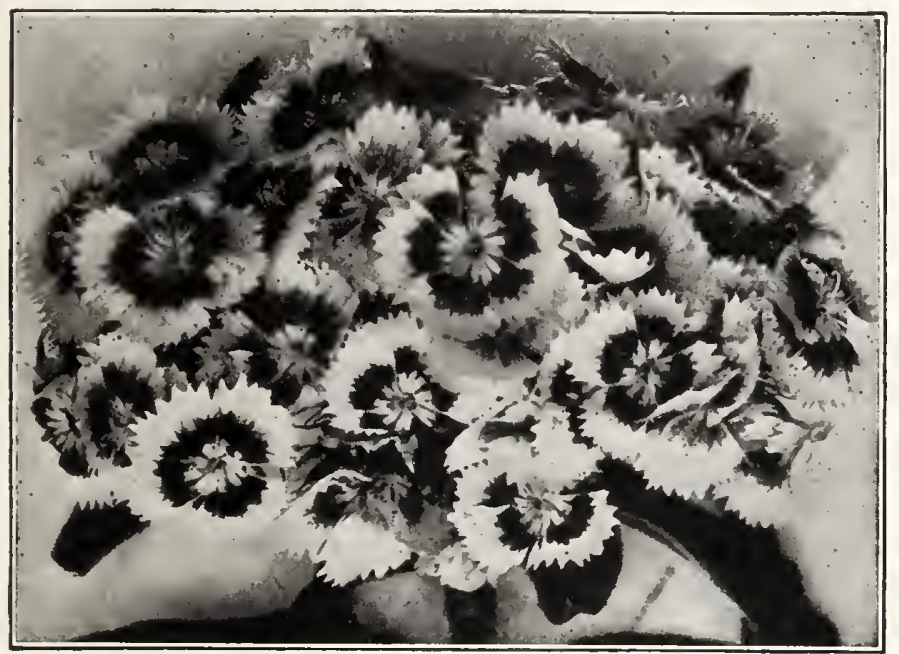

Single Sweet William

\section{SWEET WILLIAM (Dianthus Barbatus)}

Auricula Flowered. Single mixed Trade pkt. Oz. $1 / 4 \mathrm{lb}$. $\$ 0.15 \quad \$ 0.50 \quad \$ 1.75$

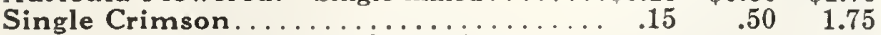
Single Newport Pink. Salmon pink $\quad \begin{array}{lll}30 & 1.25 & 4.50\end{array}$ Single Scarlet Beauty. Rich deep scarlet... $\quad .30 \quad 1.25 \quad 4.50$

Single Velvety Maroon..

Single White.....

Single Mixed. Ail colors

Double Mixed. All colors

Annual Single Mixed.

$\begin{array}{rr}1.25 & 4.50 \\ .50 & 1.75\end{array}$

1.75

$35 \quad 1.25$

$.60 \quad 2.25$

\section{| THALI CTRUM}

Hardy perennial plants, with finely cut foliage. Trade pkt. Oz. Aquilegifolium. Columbine-like foliage; feathery

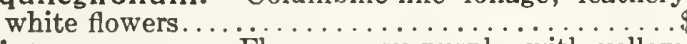

Dipterocarpum. Flowers rosy purple, with yellow anthers; fine for cutting

\section{TORENIA}

Excellent for bedding, also for baskets, window boxes, etc.

Fournieri Grandiflora. Blue. Trade pkt. Oz.

\section{TRITOMA (Red Hot Poker)}

Hybrida Mixed.

\section{TROLLIUS (Globe Flower)}

Hybridus. Bright yellow, buttercup-shaped flowers; perennial....

$\$ 0.50 \$ 2.50$

$.30 \quad 1.25$

\section{TUNICA}

Saxifraga. A low growing hardy perennial with slender foliage and innumerable tiny star-like pale pink flowers; an excellent rock plant; 4 to 6 inches .

\section{VALERIANA (Garden Heliotrope)}

Mixed. Hardy perennial border plant, with large fragrant flowers; fine for bouquets

\section{VERONICA (Speedwell)}

A showy, hardy perennial border plant of easy culture; fine for bouquets.

Longifolia. Long spikes of rich flowers Trade pkt. $\mathrm{Oz}$. Spicata. Bright blue. $\$ 0.30 \$ 1.50$ $30 \quad 1.50$

\section{VINCA}

An excellent bedding plant; seed should be sown early.

Alba. White, with rose center Trade pkt. $\mathrm{Oz}$.

$\begin{array}{lll} & \$ 1.00 & \$ 3.50\end{array}$

Alba Pura. Pure white................ .25 $1.00 \quad 3.50$

Rosea. Pink...................25 $1.00 \quad 3.50$

Mixed ...................... $20 \quad .75 \quad 2.50$

\section{VIOLA}

Trade pkt. $\mathrm{Oz}$.

Jersey Gem (New). Dwarf habit; continuous bloomer; color, pure rich violet, slightly perfumed. . . . \$1.00

Bosniaca (Johnny Jump-up). Free bloomer; small leaves, purple flowers.............

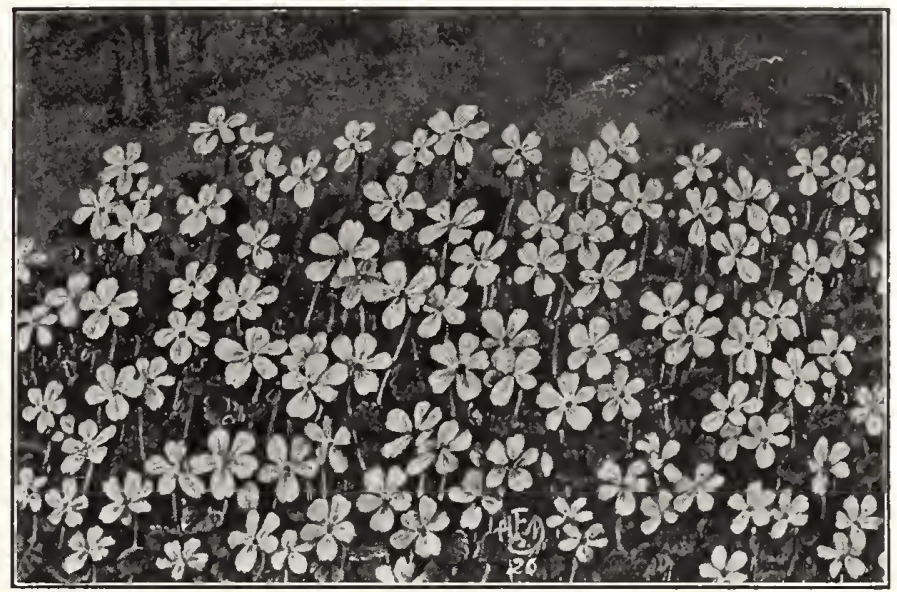

Viola Cornuta

\section{VIOLA CORNUTA (Tuited Pansies)}

Admiration. Dark blue

Apricot. Apricot yellow, tinged orange.

Mauve Queen. Lovely mauve color.

Perfection. Light blue

Rosy Gem. Compact habit; rosy pink flowers

White Perfection. Pure white.

Yellow Perfection. Golden yellow .

Mixed. All colors...............

\section{VIOLET (Viola Odorata)}

Single Blue Czar

\section{WALLFLOWER}

Double Brown

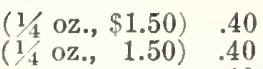

\section{" Mixed...}

Early Flowering Double Mixed. An extra early variety, flowering from seed in 90 days

Paris Extra Early Mixed. Single flowering; blooms the first year from seed; excellent for forcing

Single Mixed.

$$
\text { (1/4 lb., 75c.) } \quad .15
$$

\section{YUCCA (Adam's Needle)}

Filamentosa. A perennial used as individual specimens in the lawn or shrubbery border; spikes 4 to 5 feet high with creamy white, bell-shaped flowers

\section{Testimonial}

Harrisburg, $\mathrm{Pa}$.

Kindly send me the following articles. My last order for seed from you was more than satisfactory and I fully believe more than $90 \%$ of all seeds germinated.

Reilly, Florist. 


\section{ASPARAGUS ROOTS}

(Ready last of October)

2 Year Old Roots 100 By P.P. 1000

Barr's Mammoth.

Giant Argenteuil.

$\$ 1.10 \quad \$ 1.25 \quad \$ 9.50$

Palmetto or Eclipse.

$\begin{array}{lll}1.10 & 1.25 & 9.50\end{array}$

Washington.

$\begin{array}{lll}1.10 & 1.25 & 9.50\end{array}$

$\begin{array}{lll}1.35 & 1.50 & 11.50\end{array}$

\section{BEANS (Dwarf Green Podded Varieties)}

If Beans are wanted by parcel post, please add postage as follows: $10 \mathrm{c}$. for $1 \mathrm{lb}$.; $15 \mathrm{c}$. for $2 \mathrm{lbs}$.; $20 \mathrm{c}$. for $5 \mathrm{lbs}$; $30 \mathrm{c}$. for $10 \mathrm{lbs}$. Lb. 2 lbs. 5 lbs. 10 lbs.

Black Valentine.............. \$0.30 $\$ 0.55 \quad \$ 1.25 \quad \$ 2.30$

Bount iful.

Early Mohawk

.35

.65

1.50

$.75 \quad 1.75$

$\begin{array}{ll}.75 & 1.75 \\ 65 & 1.40\end{array}$

Early Red Valentine.

.35

Masterpiece

.35

.65

.85

1.50

2.00

Stringless Green Pod........

Triumph of the Frames

.35

.60

1.65

1.40

$1.15 \quad 2.75$

\section{BEANS (Dwart Wax Podded Varieties)}

Black Wax (Pencil Pod). Lb. 2 lbs. 5 lbs. 10 lbs. Improved Rust Proof Golden Wax $\begin{array}{rrrr}\$ 0.35 & \$ 0.65 & \$ 1.40 & \$ 2.60\end{array}$

Round Podded Kidney Wax....... $\quad .35 \quad \begin{array}{llll}.65 & 1.45 & 2.70\end{array}$

Stringless Ref ugee Wax ........ $.35 \quad .65 \quad 1.40$

Sure Crop Stringless Wax $\ldots \begin{array}{lll}35 & 65 & 1.40\end{array}$

Wardwell's Kidney Wax . . . . . . . . $.35 \quad .65 \quad 1.40$

BEE'T (Table Varieties)

\begin{tabular}{|c|c|c|c|c|}
\hline & Oz. & $1 / 4 \mathrm{lb}$. & Lb. & 5 lbs. \\
\hline Arlington Favorite & $\$ 0.10$ & $\$ 0.30$ & $\$ 1.00$ & $\$ 4.75$ \\
\hline assano Extra Early & .10 & .30 & 1.00 & 4.75 \\
\hline Bastian's Early Blood Turnip. & .10 & .30 & 1.00 & 4.75 \\
\hline Bastian's Half Long Blood & .10 & .35 & 1.10 & 5.25 \\
\hline nson Globe. & .10 & .30 & 1.00 & 4.75 \\
\hline Crosby's Egyptian. & .15 & .45 & 1.25 & 6.00 \\
\hline $\begin{array}{l}\text { Detroit Dark Red... } \\
\text { Detroit Dark Red } \text { Michell's Specia }\end{array}$ & .15 & .45 & 1.25 & 6.00 \\
\hline$\ldots \ldots \ldots \ldots \ldots \ldots \ldots$ & .20 & .50 & 1.50 & 7.25 \\
\hline arly Wor & .15 & .45 & 1.25 & 6.00 \\
\hline pse & .10 & .30 & 1.00 & 4.7 \\
\hline & .10 & .30 & 1.00 & 4.75 \\
\hline & .15 & .45 & 1.25 & 6.00 \\
\hline iell' & .25 & .80 & 2.75 & 13.50 \\
\hline
\end{tabular}

\section{BROCCOLI}

Oz. 1/4lb. Lb.

Early Green Calabrese . . . . . . . . . . . \$1.00 \$3.25 $\$ 12.00$

White Cape........................ $40 \quad \begin{aligned} & \$ .35 \\ & 5.00\end{aligned}$

\section{BRUSSELS SPROUTS}

Long Island Half Dwarf. . . . . . . . . . . .25

Matchless Improved.

.25

\section{CABBAGE (Early Varieties)}

All Head.

$\mathrm{Oz}$.

Baby Head

$\$ 0.30$

Charleston or Large Wakefield

Copenhagen Market

Extra Early Jersey Wakefield

Golden Acre.

Henderson's Early Summer

$\$ 1 / 4 \mathrm{lb}$.

$\$ 0.75$

1.65
80

.80
1.10

1.00

1.35

.75

\section{CABBA GE (Late Varieties)}

All Season (Vandergaw).

Danish Ball Head.

Danish Boundhead

Late Flat Dutch

Perfection Drumhead Savoy

Red Dutch Drumhead

\section{CAULIFLOWER}

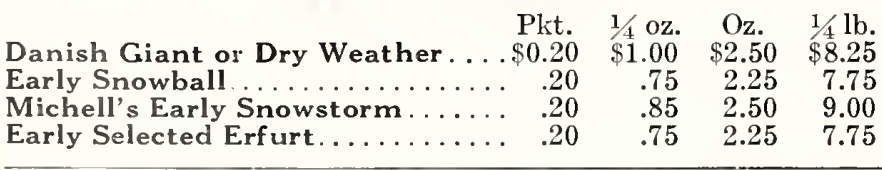

$.75 \quad 2.50$

$1.10 \quad 3.75$

$1.10 \quad 3.75$

$.70 \quad 2.50$

$.90 \quad 3.25$

$\begin{array}{rr}.90 & 3.25 \\ 1.00 & 3.75\end{array}$
Chantenay Half Long. 10c. per oz.; $1 / 4 \mathrm{lb}$. 35 c.; $\$ 1.00$ per lb.; 5 lbs., \$4.75.

Coreless or Nantes Half Long. 15c. per oz.; 1/4 lb., 45c.; $\$ 1.25$ per lb.; 5 lbs., $\$ 6.00$.

Danver's Half Long. 10c. per oz.; 1/4 lb. 35c.; $\$ 1.00$ per lb.; 5 lbs., $\$ 4.75$.

Early Half Long Scarlet. $15 \mathrm{c}$. per oz.; $1 / 4$ lb., 45c.; $\$ 1.25$ per lb.; 5 lbs., $\$ 6.00$.

Early Scarlet Horn. 10c. per oz.; $1 / 4$ lb., 35c.; $\$ 1.00$ per lb.; 5 lbs., $\$ 4.75$.

Guerande or Oxheart. $10 \mathrm{c}$. per oz.; $1 / 4$ lb., 35c.; $\$ 1.00$ per lb.; 5 lbs., $\$ 4.75$.

I m proved Long Orange. 10c. per oz.; $1 / 4$ lb., 35c.; $\$ 1.00$ per lb.; 5 lbs., $\$ 4.75$.

\section{CARROTS}

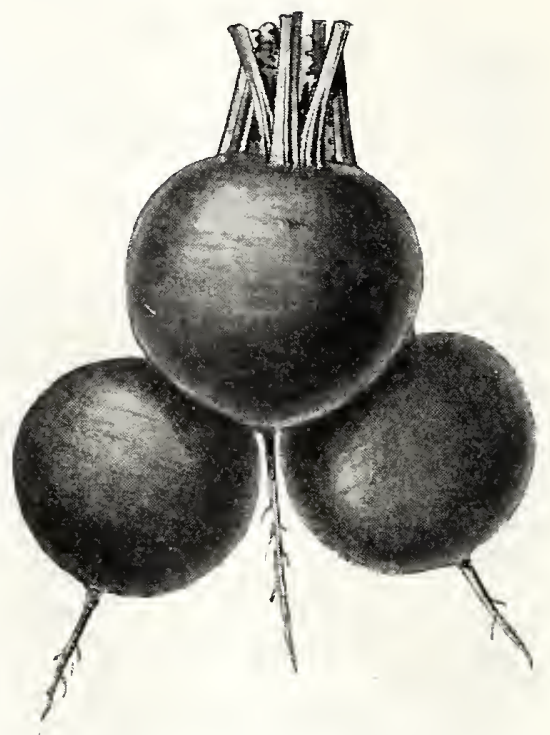

Carrot, Very Early Short Horn

Rubicon Half Long. 10c. per oz.; 1/4 lb., 35c.; $\$ 1.00$ per lb.; 5 lbs., $\$ 4.75$.

Very Early Short Horn or French Forcing. 20c. per oz.; $1 / 4$ lb., 50c.; $\$ 1.50$ per lb.; 5 lbs., $\$ 7.25$.

White Belgian. 10c. per oz.; 1/4 lb., 30c.; 90c. per lb.; 5 lbs., $\$ 4.25$.

\section{CELERY}

Easy Blanching

Oz. $1 / 4 \mathrm{lb} . \quad \mathrm{Lb}$.

$\ldots 0.35 \quad \$ 1.10 \quad \$ 4.00$

Easy Blanching (Penna. grown) . . . . . . . .90 $\quad 3.25 \quad 12.00$

Emperor............................ $30 \quad .85 \quad 3.00$

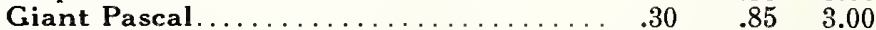

Golden Plume ................... $1.10 \quad 3.85 \quad 15.00$

Golden Self Blanching (French Grown Seed) Self Blanching (American Grown

Golden Self Blanching (American Grown

Pink Plume.

White Plume. .

Winter King. . .

$\begin{array}{lll}.75 & 2.60 & 10.00\end{array}$

Winter Queen

$1.60 \quad 6.00$

$1.60 \quad 6.00$

$.85 \quad 3.00$

$.85 \quad 3.00$

$85 \quad 3.00$

\section{CHICORY}

Witloof

\section{COLLARDS}

Georgia or Southern...............

$.15 \quad .35 \quad 1.00$

\section{CORN SALAD} $\begin{array}{lllll} & \mathrm{Oz} . & 1 / 4 \mathrm{lb} . & \mathrm{Lb} . & 5 \mathrm{lbs} . \\ \text { Large Leaved, Round Seeded } \ldots . . \$ 0.15 & \$ 0.45 & \$ 1.50 & \$ 7.25\end{array}$

\section{GARDEN CRESS (Pepper Grass)}

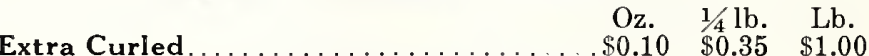

\section{WATER CRESS}

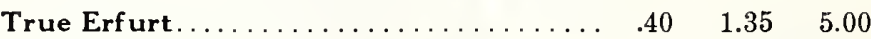

\section{EGG PLANT}

Black Beauty

Oz. $1 / 1 \mathrm{lb}$. Lb.

Florida High Bush....................... $\quad .50 \quad 1.60 \quad 6.00$

Michell's New York Improved........... $\quad .50 \quad 1.60 \quad 6.00$

For complete list of Vegetable Seeds, see our General Seed catalog, mailed free on request. 


\section{MICHELL'S VEGETABLE SEEDS, ETC.}

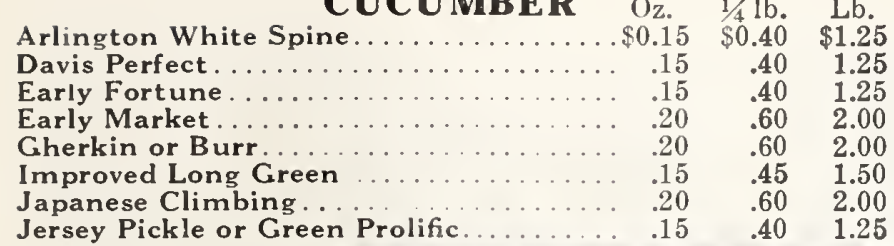

\section{ENGLISH FORCING CUCUMBERS}

Lockie's Perfection

Sion House

Telegraph

Tender and True

Either of the above, 20c. per pkt. of 10 seeds; 100 seeds, $\$ 1.75$.

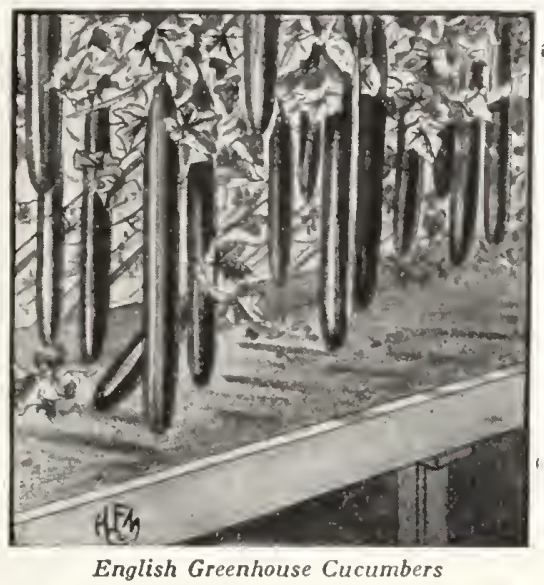

ENDIVE

Broad Leaved Batavian (Escarolle)

Giant Fringed (Oyster Endive)...

Improved Green Curled

White Curled (Self Blanching)...

\section{KALE OR BORECOLE}

$\begin{array}{rr}\text { Oz. } & 1 / 4 \mathrm{lb} . \\ \$ 0.15 & \$ 0.35 \\ .10 & .30 \\ .10 & .25\end{array}$

$\mathrm{Oz}$.
$\$ 0.15$
.15
.15
.15
$\mathbf{L E}$
$1 / 1 \mathrm{lb}$.
$\$ 0.35$
.30
.25

$1 / 4 \mathrm{lb}$.

Lb.

$\$ 0.40 \$ 1.25$

$.40 \quad 1.25$

$.40 \quad 1.25$

$40 \quad 1.25$

Lb. 5 lbs.

$\$ 1.00 \$ 4.75$

Dwarf Green Curled.

Imperial Long Standing.

.10

\section{LETTUCE (Heading Varieties)}

\begin{tabular}{|c|}
\hline $\begin{array}{l}\text { ing } \\
\text { il's } \\
\text { nett } \\
\text { fork }\end{array}$ \\
\hline
\end{tabular}

$\mathrm{Oz}$.

$\$ 0.20$
.20

.20

.20
.20
.20

.20

.20

.20

.20

.20

.20

.20

.20

.20

$\begin{array}{ll}.85 & 4.00 \\ .75 & 3.50\end{array}$

\section{LETTUCE (Loose Leaf Varieties)}

Black Seeded Simpson

Eariy Curled Silesian.

Early Curled Simpson

Grand Rapids.

$\mathrm{Oz}$.

$\$ 0.20$

$\$ 0.4$

.20

.20

lb. Lb.

0.45

$.45 \quad 1.50$

$.45 \quad 1.50$

$.55 \quad 1.75$

$.55 \quad 1.75$

$.45 \quad 1.50$

$.55 \quad 1.75$

$.45 \quad 1.50$

$45 \quad 1.50$

$.45 \quad 1.50$

$.55 \quad 1.75$

$.55 \quad 1.75$

$.60 \quad 2.25$

$.45 \quad 1.50$

$\begin{array}{ll}55 & 1.75\end{array}$

$.45 \quad 1.50$

\section{LETTUCE (Cos or Romaine)}

Oz. 1/lb. Lb.

MELONS FOR FORCING

Blenheim Orange..

$\$ 0.20$

Windsor Castle .................. 20

Sutton's A1.......... (In original pkts.) 1.00

100 seeds

$\$ 1.50$

1.50

Lb.

$\$ 1.50$

$.45 \quad 1.50$

$.45 \quad 1.50$

MUSTARD $\quad \mathrm{Oz} . \quad 1 / 4 \mathrm{lb} . \quad \mathrm{Lb}$.

Southern Giant Curled. . . . . . . . . \$0.10 $\$ 0.25 \quad \$ 0.75$

White or Yellow................... $\quad .10 \quad .25 \quad .65$

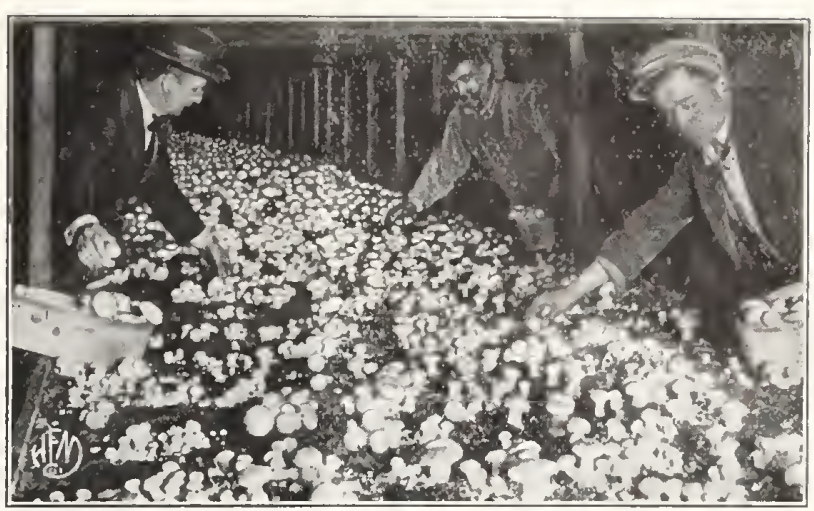

\section{MICHELL'S MUSHROOM SPAWN}

PURE SPORE CULTURE SPAWN

This spawn is made in quart milk jars under absolutely sterile conditions. The bottle and materials are sterilized under steam pressure, so that every mold, weed seed or insect is destroyed and each bottle contains nothing but the pure spawn; each jar contains enough for 30 to 40 square feet. The sterile spawn is dried thoroughly and each piece wrapped in tissue paper and contains full instructions.

If wanted by Parcel Post, allow 10c. per carton for postage. Per carton..........\$0.85|25 cartons.......... \$18.75 12 cartons.......... 9.50|60 cartons .......... 42.00

\section{PURE CULTURE BRICK SPAWN}

A crop is produced with good spawn, a little care and patience in about 5 to 10 weeks, and continues in bearing about two months. New beds can be started at intervals which will give a supply the entire season. Ask for our Free Booklet on Mushroom Culture. 1 Brick will spawn 8 to 10 square feet.

Direct No. 8. Cream White. For use from April to October. Direct No. 9. Pure White. For use from October to April.

Per brick..........\$0.30| Per 25 bricks .......\$5.00

Per 5 bricks........ 1.25 Per 50 bricks........ 10.00 Per 10 bricks ..................... 19.00 Per 1000 bricks........... $\$ 185.00$

If wanted by Parcel Post, allow for postage at the rate of 10c. per brick; 20c. per 5 bricks; 30c. per 10 bricks.

\section{MUSHROOM OR HOTBED THERMOMETERS}

Iron Point, oxidized finish, $\$ 2.00$ each (by parcel post, $\$ 2.15$ ). Thermometers should, wherever possible, be sent by express. We do not guarantee safe arrival if forwarded by parcel post.

Ailsa Craig

ONION

Bermuda White

Large Red Wethersfield

Prizetaker.

Southport White Gilobe

Southport Yellow Globe

White Barletta.

White Portugal or Silver Skin

Yellow Globe Danver's.

Yellow Strasburg..

$\begin{array}{rr}\text { Oz. } & 1 / 4 \mathrm{lb} . \\ \$ 0.25 & \$ 0.70 \\ .40 & 1.35 \\ .20 & .60 \\ .20 & .65 \\ .25 & .85 \\ .20 & .65 \\ .25 & .70 \\ .25 & .75 \\ .20 & .60 \\ .20 & .55\end{array}$

Lb.

$\$ 2.50$

5.00

2.00

2.25

3.00

2.25

2.50

2.75

2.25

ONION SETS

One quart to 50 foot row; 8 bushels per acre.

Red.

White

Yellow

White Multiplier

Potato Onions

Prices will be quoted

Shallots

Garic Sets

Tree or Top Onions

We give 32 lbs. per bushel on Onion Sets, except Tree or Top Onions which are sold on basis of $28 \mathrm{lbs}$. per bushel.

For complete list of Vegetable Seeds see our General Seed catalog, mailed free on request. 


\section{PARSLEY}

Champion Moss Curled Double Curled or Covent Garden. Hamburg or Rooted.

Plain or Single.

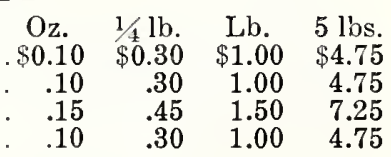

\section{PEAS (Extra Early Varieties)}

If Peas are wanted by Parcel Post, add for postage as follows: 10c. for 1 lb.; 15c. for 2 lbs.; 20c. for 5 lbs.; 30c. for $10 \mathrm{lbs}$.

Alaska .

Dandy Extra Early

Early Eight Weeks

Early June.......

Gradus or Prosperity

Laxtonian.........

Little Marvel....

Nott's Excelsior.

Special Extra Early

Sutton's Excelsior

Thos. Laxton.

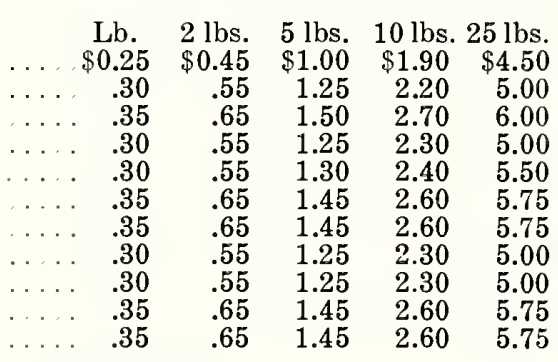

\section{PEPPER}

Bell or Bull Nose

California Wonder

Cayenne

Chinese Giant. .

Golden Dawn.

Harris' Early Giant

Neapolitan.

Pimiento. .

Red Chili.

Ruby Giant

Ruby King .

Tomato, or Squash

World Beater...

\begin{tabular}{rrr}
\multicolumn{1}{l}{ Oz. } & \multicolumn{1}{l}{ l/lb. } & Lb. \\
$\$ 0.30$ & $\$ 0.95$ & $\$ 3.50$ \\
.60 & 2.10 & 8.00 \\
.35 & 1.10 & 4.00 \\
.55 & 1.85 & 7.00 \\
.40 & 1.35 & 5.00 \\
.55 & 1.85 & 7.00 \\
.35 & 1.10 & 4.00 \\
.30 & .95 & 3.50 \\
.40 & 1.35 & 5.00 \\
.35 & 1.20 & 4.50 \\
.35 & 1.10 & 4.00 \\
.35 & 1.20 & 4.50 \\
.35 & 1.20 & 4.50
\end{tabular}

\section{RADISH (Early Varieties)}

Crimson Giant. Oz. $1 / 4 \mathrm{lb}$

Early Scarlet Gilo $\$ 0.10 \quad \$ 0.30$

French Breakfast. .

Icicle

Long Scarlet Short Top

Philadelphia White Box

Round Red or Button.

Scarlet or Cardinal Globe.

Scarlet Turnip White Tipped

\section{RADISH (Summer and Winter Varieties)}

Oz. 1/1 lb. Lb. 5 lbs.

China Rose White Chinese....

Long Black Spanish.....

White Strasburg.

$\$ 0.10 \quad \$ 0.30 \quad \$ 0.90 \quad \$ 4.25$

$\begin{array}{llll}.10 & .30 & .90 & 4.25\end{array}$

$\begin{array}{llll}.10 & .30 & .90 & 4.25\end{array}$

\section{RHUBARB ROOTS}

(Ready October 1st for Fall planting; April 1st for Spring planting)

Rhubarb is readily obtainable in winter by planting four year old clumps in good soil in a cool cellar; a barrel or peach basket either without a bottom, should be placed over each root to draw the top up. Also does well under greenhouse benches. In the spring the roots may be planted out for use another season. The roots should be subjected to a slight frost before planting indoors. Victoria. $\$ 1.00$ per doz. (by Parcel Post, $\$ 1.25$ ); per $100, \$ 7.00$; $\$ 60.00$ per 1000 .

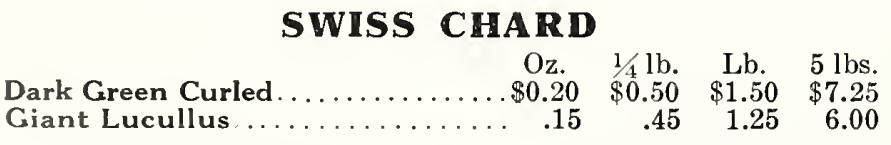

For complete list of Vegetable Seeds see our General Seed catalog, mailed free on request.

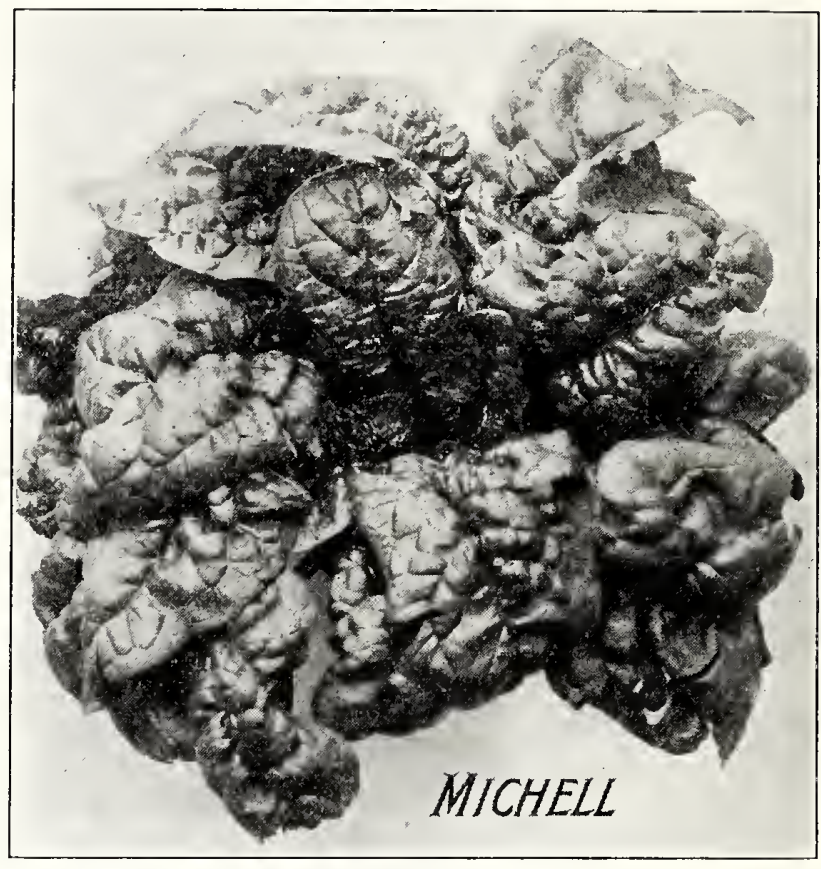

Spinach, Bloomsdale Savoy

SPINACH

$\begin{array}{llllll} & \text { Oz. } & 1 / 4 \mathrm{lb} . & \text { Lb. } & 5 \mathrm{lbs} . & 10 \mathrm{lbs} .25 \mathrm{lbs} . \\ \text { Bloomsdale Savoy... } & \$ 0.15 & \$ 0.40 & \$ 1.60 & \$ 2.80 & \$ 6.25\end{array}$

$\begin{array}{llllll}\text { King of Denmark. . . } & .15 & .40 & 1.50 & 2.50 & 5.75\end{array}$

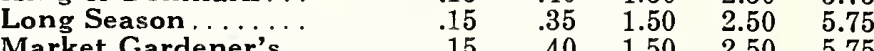

$\begin{array}{llllll}\text { Market Gardener's : } & .15 & .40 & 1.50 & 2.50 & \mathbf{5 . 7 5}\end{array}$

Dark Green Leaved

$\begin{array}{llllll}\text { Savoy ............ } & .15 & .40 & 1.50 & 2.50 & 5.75\end{array}$

Virginia Bilight

$\begin{array}{llllll}\text { Resistant Savoy. . . } & .15 & .40 & 1.60 & 2.80 & 6.25\end{array}$

New Zealand.......\$0.10 $\quad .35 \quad 1.00 \quad 4.75 \quad 9.00$

The New Zealand variety is especially desirable for Summer and Fall use; seed should be soaked in warm water for about 12 hours before sowing.

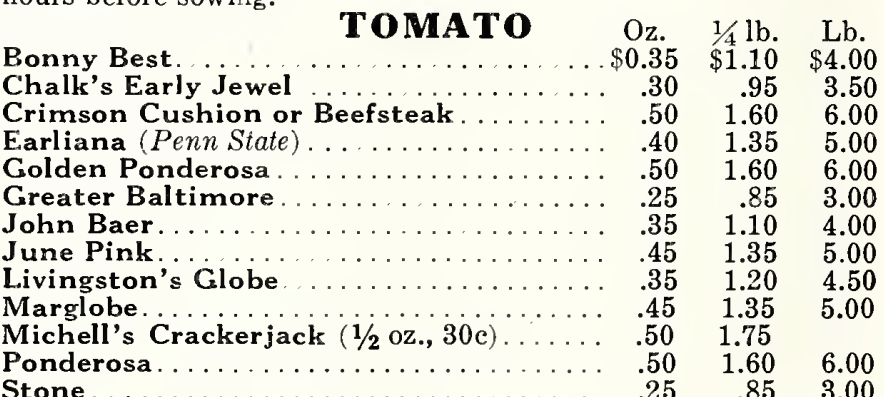

\section{TOMATO (Forcing Varieties)}

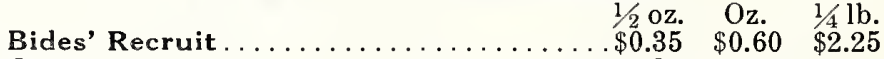
Comet............................. $30 \quad \$ 0.50 \quad \$ 2.25$

Sutton's Perfection. Original pkt., $\$ 1.00 ; 3$ pkts., $\$ 2.85$.

\section{TURNIP}

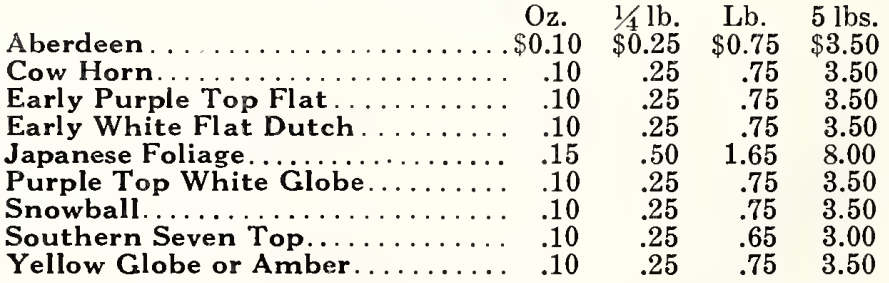

RUTA BAGA

$\begin{array}{llllll}\text { Private Stock Purple Top Yellow . } & .10 & .30 & .85 & 4.00\end{array}$ 


\section{MICHELL'S RELIABLE GRASS SEEDS}

Our connections with the best grass seed producers in America and Europe place us in a position of advantage for our supplies, chiefly because of the great volume of grass seeds we contract for. Some people have an idea that price is the only factor to consider in grass seed buying; while this has its place, it should be an after thought. "Quality is paramount." We are alway pleased to submit samples with prices for comparison and let you be the judge.

Prices subject to market changes.

GRASS MIXTURES FOR LA WNS

A complete description as to the adaptability of these grass seed mixtures will be furnished in our retail catalog, a copy of which may be had on request.

Michell's Superior Bent Grass Mixture. Composed of the finest grasses obtainable, consisting chiefly of the leading varieties of Bent grasses, which are the foundation of the best putting greens. We recommend sowing this formula at the rate of one pound to a space $15 \times 20$ feet, or 300 square feet. $\$ 1.10$ per lb.; 5 lbs., $\$ 5.00 ; \$ 23.75$ per 25 lbs.; 100 lbs., $\$ 85.00$.

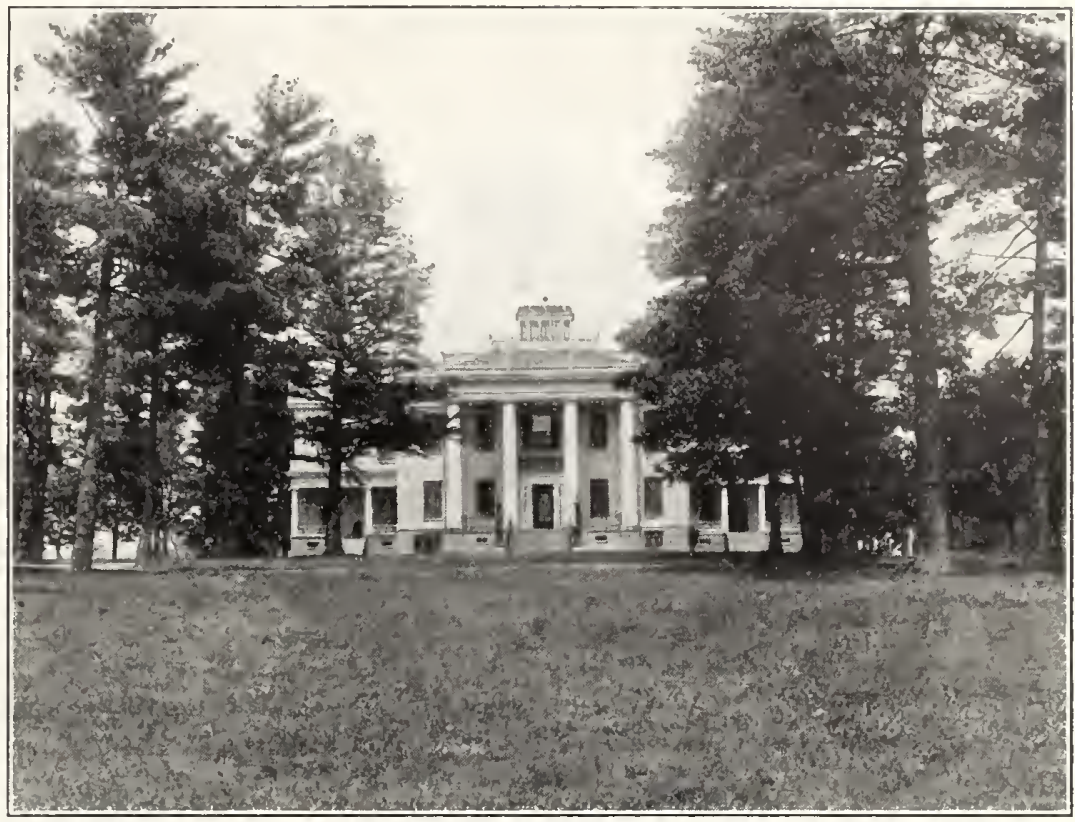

Michell's Clover Lawn. For sandy soils, or for seashore lawns. 30 lbs. per bu. 30c. per pt.; qt., 55c.; $\$ 1.05$ per 2 qts.; 4 qts., $\$ 2.00 ; \$ 3.75$ per pk.; bu., $\$ 14.00 ; \$ 42.50$ per $100 \mathrm{lbs}$.; $1000 \mathrm{lbs}$., $\$ 400.00$.

Michell's Top Notch. $25 \mathrm{lbs}$. per bu. Can justly be called the top notch of quality. $\$ 3.25$ per pk.; bu., $\$ 11.00 ; \$ 42.00$ per 100 lbs.; 1000 lbs., $\$ 390.00$.

Michell's Green Velvet. Produces a perfect lawn in 4 to 5 weeks time. $20 \mathrm{lbs}$. per bu. 20c. per pt.; qt., 35c.; 65c. per 2 qts.; 4 qts., $\$ 1.20 ; \$ 2.25$ per pk.; bu., $\$ 8.00 ; \$ 36.50$ per 100 lbs.; 1000 lbs., $\$ 330.00$.

Michell's Evergreen. The standard lawn mixture. 20 lbs. per bu. 15 c. per pt.; qt., 30c.; 55c. per 2 qts.; 4 qts., $\$ 1.00 ; \$ 1.75$ per pk.; bu., $\$ 6.25 ; \$ 30.00$ per 100 lbs., 1000 lbs., $\$ 280.00$.

Michell's Shaded Lawn. Will produce perfect swards in shaded places. 20 lbs. per bu. 20c. per pt.; qt., 35c.; 65c. per 2 qts.; 4 qts., $\$ 1.20 ; \$ 2.25$ per pk.; bu., $\$ 8.00 ; \$ 36.50$ per 100 lbs.; 1000 lbs., $\$ 345.00$.

Michell's Fairmount Park. For general lawn making, a very satisfactory mixture. 20 lbs. per bu. 13c. per pt.; qt., 20c.; 40 c. per 2 qts.; 4 qts., 75 c.; $\$ 1.40$ per pk.; bu., $\$ 5.25 ; \$ 25.00$ per 100 lbs.; 1000 lbs., $\$ 230.00$.

Michell's Seashore Formula. 20 lbs. per bu. 20c. per pt.; qt., 35c.; 65 c. per 2 qts.; 4 qts., $\$ 1.20 ; \$ 2.25$ per pk.; bu., $\$ 7.50$; $\$ 36.50$ per 100 lbs.; 1000 lbs., $\$ 345.00$.

Michell's Terrace or Embankment. 20 lbs. per bu. 20c. per pt.; qt., 35c.; 65c. per 2 qts.; 4 qts., $\$ 1.10 ; \$ 2.00$ per pk.; bu., $\$ 7.50 ; \$ 36.50$ per 100 lbs.; 1000 lbs., $\$ 345.00$.

Michell's Southern States Evergreen. Especially for southern latitudes. 20 lbs. per bu. 20c. per pt.; qt., 35c.; 65c. per 2 qts.; 4 qts., $\$ 1.20$; $\$ 2.25$ per pk.; bu., $\$ 8.00 ; \$ 36.50$ per 100 lbs.; 1000 lbs., $\$ 345.00$.

Michell's Special Sod. 20 lbs. per bu. 20c. per pt.; qt., 35c.; 65 c. per 2 qts.; 4 qts., $\$ 1.10 ; \$ 2.00$ per pk.; bu., $\$ 7.50 ; \$ 35.00$ per $100 \mathrm{lbs}$.; $1000 \mathrm{lbs}$, $\$ 330.00$.

Michell's Greendel Lawn Seed. Recommended for landscape operation work. $\$ 5.00$ per bu.; 100 lbs., $\$ 22.00 ; \$ 200.00$ per 1000 lbs.

MIXTURES FOR PLEASURE GROUNDS

Michell's Athletic Field Mixture. 20 lbs. per bu. $\$ 1.80$ per pk.; bu., \$6.25; $\$ 30.00$ per 100 lbs.; 1000 lbs., $\$ 280.00$.

Michell's Fairways (Golf Course) Mixture. 20 lbs. per bu. $\$ 1.80$ per pk.; bu., $\$ 6.25$; $\$ 30.00$ per 100 lbs.; 1000 lbs., $\$ 280.00$.

Michell's Putting Green Mixture. $25 \mathrm{lbs}$. per bu. 35c. per pt.; qt., 65 c.; $\$ 1.15$ per 2 qts.; 4 qts., $\$ 2.15 ; \$ 4.00$ per pk.; bu., $\$ 14.00 ; \$ 52.00$ per 100 lbs.; 1000 lbs., $\$ 500.00$.

\section{MISCELLANEOUS MIXTURES}

Michell's Permanent Pasture Grass Seed. $20 \mathrm{lbs}$. per bu. $\$ 1.50$ per pk.; bu., $\$ 5.75 ; \$ 27.00$ per 100 lbs.; 1000 lbs., $\$ 255.00$.

Michell's Permanent Hayfield Grass Seed. 20 lbs. per bu. $\$ 1.50$ per pk.; bu., $\$ 5.75 ; \$ 27.00$ per $100 \mathrm{lbs} . ; 1000$ lbs., $\$ 255.00$.

GRASSES IN SEPARATE VARIETIES
On account of market fluctuations on many varieties of grass seeds, quantity prices on separate varieties have been omitted, but we will be pleased to quote upon application.

Bent Grass, Certified Prince Edward Island. Average purity $95 \%$. An extra hardy strain of Colonial Bent, grown on Prince Edward Island, under very severe winter conditions. Certified and sealed in $50 \mathrm{lb}$. bags by the Canadian Department of Agriculture. $\$ 2.00$ per lb.; 5 lbs., $\$ 9.75 ; \$ 19.00$ per 10 lbs.; 50 lbs., $\$ 75.00 ; \$ 140.00$ per 100 lbs.

Bent Grass, Certified Seaside (Sometimes called Cocoos Bent). Average purity $98 \%$. The very highest quality, grown in Coos County, Oregon. Certified and sealed in $50 \mathrm{lb}$. bags. A true creeping bent, spreading rapidly by means of stolons or runners, makes ideal putting green turf. $\$ 2.50$ per lb.; 5 lbs., $\$ 11.75$; $\$ 22.50$ per 10 lbs.; 50 lbs., $\$ 87.50 ; \$ 160.00$ per $100 \mathrm{lbs}$.

Bent Grass, Colonial or Velvet. 20 lbs. per bu. $\$ 1.00$ per lb. Bent Grass, Creeping, 20 lbs. per bu. $\$ 1.00$ per lb.

Bent Grass, Rhode Island. $20 \mathrm{lbs}$. per bu. $\$ 1.00$ per lb.

Bermuda Grass. 35 lbs. per bu. 50c. per lb.

Blue Grass, Kentucky. Superfine quality. 14 lbs. per bu. 40c. per lb.

Blue Grass, Kentucky. Fancy. 14 lbs. per bu. 35c. per lb.

Blue Grass, Canadian. $14 \mathrm{lbs}$. per bu. 35c. per lb.

Crested Dogstail. 21 lbs. per bu. 40c. per lb.

Fescue, Chewing's New Zealand. 14 lbs. per bu. 45c. per lb.

Fescue, Fine Leaved. $14 \mathrm{lbs}$. per bu. 45c. per lb.

Fescue, Hard. 14 lbs. per bu. 40c. per lb.

Fescue, Meadow. 22 lbs. per bu. 25c. per lb.

Fescue, Red or Creeping. $14 \mathrm{lbs}$. per bu. 45c. per lb.

Fescue, Sheep's. 14 lbs, per bu. 40c. per lb.

Herd or Red Top, Unhulled. 10 lbs. per bu. 25c. per lb.

Orchard Grass. 14 lbs. per bu. 30c. per lb.

Red Top, Fancy Recleaned. 32 lbs. per bu. 40 c. per lb.

Rough Stalked Meadow. 14 lbs. per bu. 55c. per lb.

Rye Grass, Domestic. 20 lbs. per bu. 15c. per lb.

Rye Grass, English (Pacey's Fancy Short Seeded). 24 lbs. per bu. 20c. per lb.

Rye Grass, English or Perennial. 24 lbs. per bu. 20c. per lb. Rye Grass, Italian. 18 lbs. per bu. 20c. per lb.

Sudan Grass. 20c. per lb.

Sweet Vernal (Perennial). 80c. per lb.

Timothy. $45 \mathrm{lbs}$. per bu. 20c. per lb.

Wood Meadow. 14 lbs. per bu. 60c. per lb. 


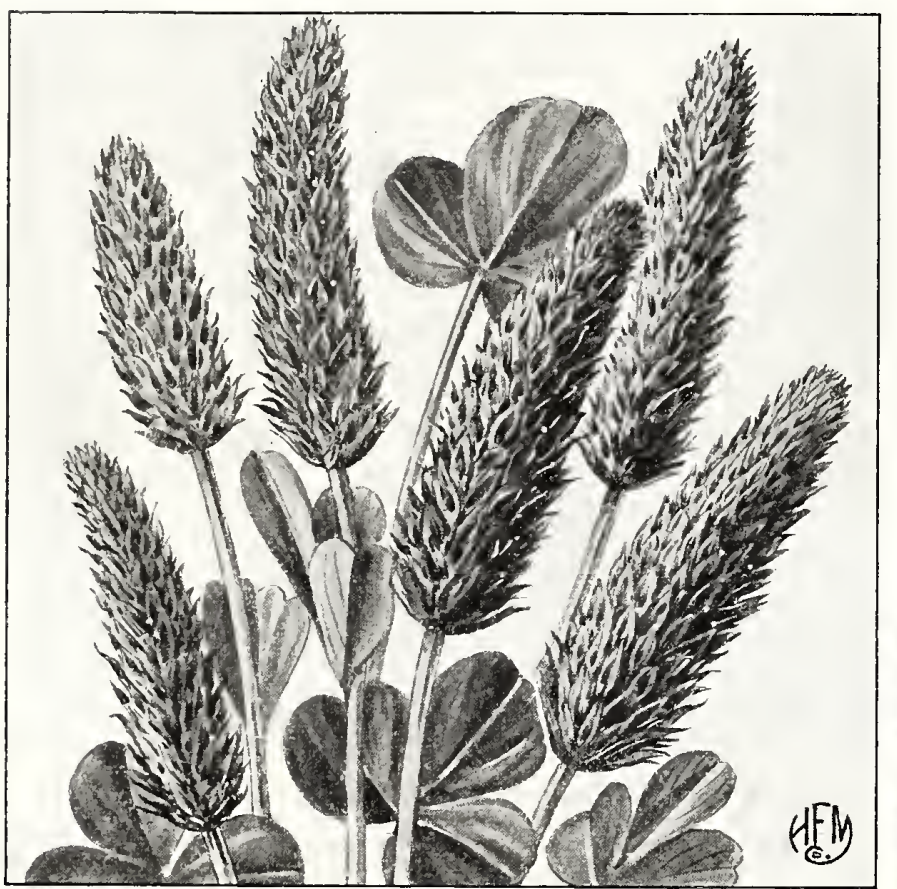

Crimson Clover

\section{CLOVERS}

Alfalfa or Lucerne (Medicago Sativa). (Non-irrigated, Western grown seed.). Sow during May, August and September, not less than $1 / 2$ bushel ( $30 \mathrm{lbs}$.) per acre, preferably with no other crop. Price on application.

Alfalfa (Grimm Strain). Claimed to be hardy in any and all regions; a heavy yielder and of deep rooting ability. It requires about 15 to $20 \mathrm{lbs}$. of Grimm Alfalfa to seed an acre on account of its great root system. Price on application.

Alsike or Swedish Clover (Trifolium Hybridum). One of the best for mixing with timothy; it is perfectly hardy in every climate or soil condition; grows 1 to 2 feet high. Sown early

in the Spring or late Summer and early Autumn, 10 to 15 lbs. per acre alone or $8 \mathrm{lbs}$. with timothy. Price on application.

Bokhara or Giant Sweet Clover (Melilotus Alba. Syn. M. Leucantha). Used either as a feed crop or as a fertilizer to plow under. Grows from 3 to 5 feet high, thriving on almost any kind of soil. Sow 15 lbs. per acre during April and August. Price on application.

Crimson Clover (Trifolium Incarnatum). This is used principally for soiling or green manuring, for which purposes it is highly valuable. If desired for feed, cut it just before it flowers. When desired for green manure, it should be allowed to mature; its height is from 1 to 2 feet. Sow any time from April to October, $20 \mathrm{lbs}$. to the acre. Price on application.

Mammoth Red Clover (Trifolium Pratense Perenne). This differs from the "Medium" being of a ranker growth and yielding more fodder per acre. Sow in early Spring or in the late Summer and Fall, using 20 lbs. per acre alone, or with other crops, 10 lbs. per acre. Price on application.

Red Clover, Medium (Trifolium Pratense). More widely known and used than any other; used principally for hay purposes. Height from 18 inches to $21 / 2$ feet. Sow early in the Spring or in the late Summer and Fall; if alone, $20 \mathrm{lbs}$. per acre, if with other crops, 10 lbs. per acre. Price on application.

White Dutch or Lawn Clover (Trifolium Repens). Choice recleaned seed. Sow 10 to $12 \mathrm{lbs}$. per acre if alone or $5 \mathrm{lbs}$. if sown on old turf or with other crops. 6c. per oz.; $1 / 4$ lb., 20c.; 35c. per $1 / 2 \mathrm{lb}$.; lb., 65c. (by parcel post, 75c.); $\$ 3.00$ per 5 lbs. (by parcel post, $\$ 3.20$ ); 10 lbs., $\$ 5.50$ (by parcel post, $\$ 5.80$ ); $\$ 30.00$ per bu. (60 lbs.); 100 lbs., $\$ 48.00$. Price for larger quantities on application.

\section{DWA RF ESSEX RAPE}

An indispensable green food for sheep and hogs; produces enormous crops. Sow 6 lbs. per acre, from April 1st to October 1st. Price on application.

\section{WINTER RYE}

Penna. Large White. Sow 1 to $11 / 2$ bushels per acre during fall. An excellent green food in spring and may be used for turning under or harvesting.

Rosen. A most prolific new variety.

Prices on Rye will be quoted upon application.

\section{RECLEANED TIMOTHY}

Our stock is of very best quality; for sowing among wheat as a second-year hay crop or for sowing alone for a first-year hay crop this is extensively used. Sow $1 / 2$ bu. per acre alone 8 to 10 quarts with wheat. Price on application.

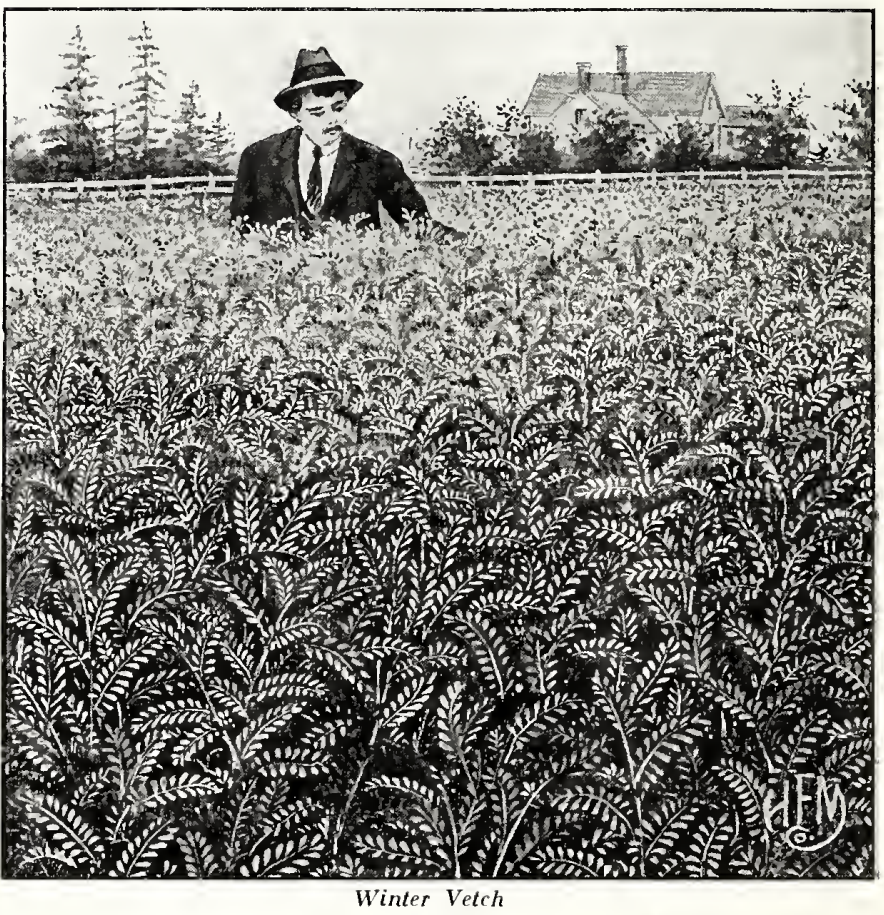

WINTER VETCH (VIcia Villosa)

True Sand or Hairy Vetch. Our stock of this is the true type; will live throughout the winter. Sow from August 1st to October 1st, broadcast 1 bu. per acre, to which we suggest adding a bushel of winter rye or wheat. In the spring it can be plowed under as green manure, or when in flower, cut for hay. Price on application.

\section{SEED WHEAT}

Forward (Bald). A wonderful stooler; heavy yielder; very hardy; straw thick and of good length; grain dark colored, of hard texture; medium early in ripening.

Leap's Prolific (Bald). A most prolific variety indeed. The grain is hard, of medium size, red and very plump.

Miracle (Bearded). This is a tremendous stooler, one grain producing as many as 25 stalks with of ten 45 grains to each head or stalk. The introducer impresses upon us very forcibly not to recommend the sowing of more than one bushel per acre.

Pennsylvania 44 (Bearded). A new variety developed from the Fulcaster, but a much larger yielder; grains red; purple straw and white chaff.

Red Wave (Bald). Heavy yielder; heads extremely long, with grains closely set; the grain is hard, large and dark red; straw long and stiff; ripens mid-season.

Prices on Seed Wheat will be quoted on application.

We can also supply at the proper season, Barley, Broom Corn, Buckwheat, Canada Field Peas, Flax, Kaffir Corn, Millet, Oats, Soja Beans, Speltz, Spring Rye, Spring Vetch, Spring Wheat, Sugar Cane, etc. 


\section{MICHELL'S HORTICULTURAL AND AGRICULTURAL ACCESSORIES}

Parcel Post charges where named are for shipment up to and including third zone; for other zones, please add additional postage.

\section{WHEELBARROWS MICHELL'S GREENHOUSE}

This is a very narrow barrow, designed for use in aisles of a greenhouse. Box measures inside, 14 ins. in front, 17 ins. in back, and 12 inches deep. Handles, 4 feet 8 inches long. Spread of handles at hand hold 20 inches, which is extreme width of barrow. Furnished in 18-inch diameter wheel. Nicely painted and striped. Price, $\$ 9.50$.

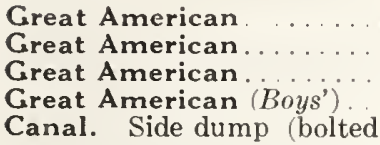

\section{SOIL PULVERIZER}

The machines are equipped with a hopper and a roller, the latter being spiked. It is turned by means of a handle and crushes the soil perfectly, avoiding necessity to sift.

$\begin{array}{cccc}\text { No. Length } & \text { Width } & \text { Height } \\ 1 & 25 \mathrm{in.} & 20 \mathrm{in.} & 40 \mathrm{in.} \\ 2 & 46 \mathrm{in.} & 20 \mathrm{in.} & 40 \mathrm{in} . \\ 3 & 46 \mathrm{in.} & 20 \mathrm{in.} & 40 \mathrm{in} .\end{array}$

Price 21.00 30.00 40.00

The rolls are 6 inches in diameter; the No. 3 size has an extra roll.

\section{SIEVES (Any size mesh)}

Made extra well, of galvanized wire and hardwood. Round shape.

18-inch Steel (extra heavy) . .

18-inch Galvanized Wire.

\section{LARGE UPRIGHT SIEVE}

For soil, gravel, sand, etc. Made in any size mesh, of extra heavy grade foundry wire. $\$ 19.00$ each
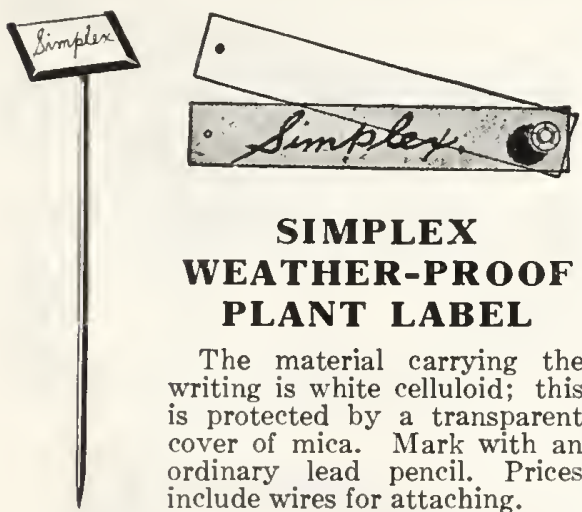

\section{SIMPLEX WEATHER-PROOF PLANT LABEL}

The material carrying the writing is white celluloid; this is protected by a transparent cover of mica. Mark with an ordinary lead pencil. Prices include wires for attaching.

Sizes

No. $2-4 \times 3 / 2$ in.......... $\$ 0.40 \quad \$ 2.85$

No. $3-5 \times 1$ in........... $.95 \quad 6.75$

If wanted by parcel post, add 10c. per 100 , for postage.

SIMPLEX WEATHERPROOF GARDEN LABEL

Iron stake, 24 inches long.

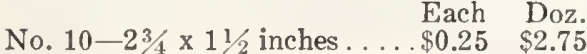

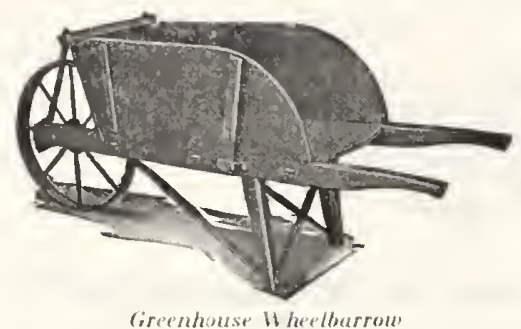

$\begin{array}{ccccc} & \text { Tire } & \text { Length } & \text { Depth } & \text { Width } \\ \text { No. } & \text { In. } & \text { In. } & \text { In. } & \text { In. } \\ 1 & 23 / 4 & 30 & 12 & 25 \\ 2 & 23 / 4 & 28 & 12 & 24 \\ 3 & 23 / 4 & 26 & 12 & 22 \\ 4 & 13 / 4 & 22 & 9 & 18\end{array}$

Price $\$ 9.00$

8.00

7.50

5.50

5.00

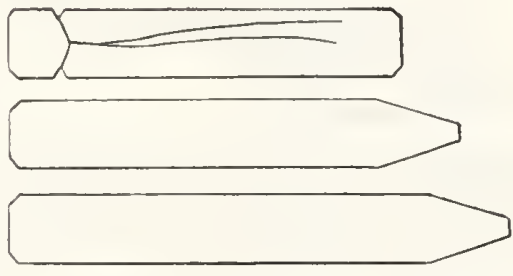

TREE LABELS, Etc.

If wanted by parcel post, add $10 \mathrm{c}$. per 100 or 25 c. per 1000 for postage. Wood, Iron Wired. Painted. . .352 .45

Wood, Copper Wired. Plain.. $\quad .30 \quad 2.25$

Wood, Copper Wired. Painted $.40 \quad 2.85$

Copper Sheet, wired, 25c.,

doz...................... 1.50

Zinc Sheet, wired, $25 \mathrm{c}$, doz each, $15 \mathrm{c}$.

\section{PAINTED POT LABELS}

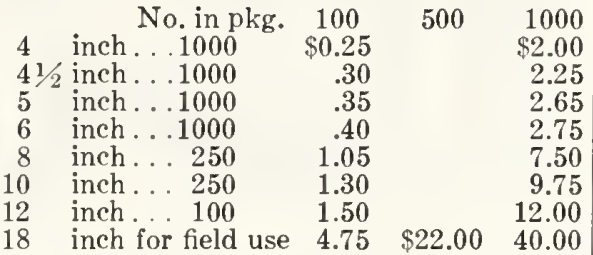

The 18-inch field labels are not painted

If pot labels are wanted by parcel post, add $10 \mathrm{c}$. per 100 , or $20 \mathrm{c}$. per 1000 (except on 10,12 or 18 inch) for postage.

\section{CELLULOID POT LABELS}

Made of white celluloid; excellent for greenhouse use.
No.
Size
$214 \times 5 / 8$ inches
Doz. 100
$\$ 0.25$
$\$ 1.80$
1.80
2.75

Wood, Iron Wired. Plain . . $\$ 0.25 \quad \$ 1.85$

\section{HOTBED SASH}

Philadelphia Style. Made of best quality cypress. Size, 3 feet, $11 / 2$ inches wide, 6 feet long, 11 inches thick. Plain not glazed or painted. Each, $\$ 3.75$.

Glazed, primed and puttied. Each, $\$ 7.00$.

Packing Charges on all Glazed Sash, 50c. per sash additional.

All glazed sash are shipped at purchaser's risk, although we pack very carefully to insure safe arrival.

\section{HOTBED MATS}

The "Burlap Style" are the best mats that it is possible to procure. They are padded with shoddy. Rats and mice do not harbor in them, and they are otherwise practically indestructible.

Burlap, Non-Waterproof. $76 \times 76$ inches, covering two regular size sash. $\$ 3.25$ each; doz., $\$ 35.00$.

Burlap, Non-Waterproof. $40 \times 76$ inches, for one sash. $\$ 2.00$ each; doz., $\$ 22.00$

Burlap one side, Waterproof Drill one side. $40 \times 76$ inches. $\$ 2.75$ each; doz., $\$ 30.00$.

Burlap one side, Waterproof Drill one side. $76 \times 76$ inches. $\$ 4.75$ each; doz., $\$ 52.50$.

\section{SHADING OR PROTECTING CLOTH}

Admirable for protecting plants, etc., from sun and at the same time allowing ventilation. Made of brown cloth.

\begin{tabular}{|c|c|c|c|}
\hline & $\begin{array}{c}\text { Yds. per } \\
\text { Piece }\end{array}$ & $\begin{array}{c}\text { Price } \\
\text { Per Yd. }\end{array}$ & $\begin{array}{l}\text { Price } \\
\text { Per Pc. }\end{array}$ \\
\hline Ligl & 60 & $\$ 0.18$ & $\$ 10.20$ \\
\hline & 50 & .22 & 10.50 \\
\hline$\ldots \ldots$ & 40 & .31 & 11.60 \\
\hline
\end{tabular}

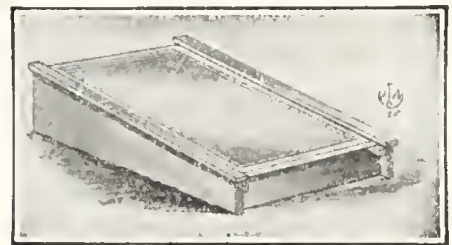

\section{CEL-O-GLASS}

Takes the place of glass in hotbed sash; unbreakable and so light in weight that they save much time and work in handling; 36 inches wide.

Less than 100 feet, per running foot. . $\$ 0.57$ Full rolls, per running foot.......... .51

\section{FLEX-0-GLASS}

A glazed cloth used in place of glass for poultry houses, hotbeds, greenhouses, etc. Transparent and readily admits light, while at the same time withholding cold, water and wind; 3 feet wide.

Cut pieces

Per Yd. $\$ 0.29$

\section{WAGON AND AUTOMOBILE HEATERS}

These heaters will keep the temperature above freezing in most any ordinary closed vehicle during the severest weather.

No. 10. Lehman. Three drawers

see cut) ...........\$12.00

Clark's Round Heater.......... 4.00

COAL FOR WAGON HEATERS

$\$ 1.10$ per 20 brickets; per 100 bricks, $\$ 7.50$.

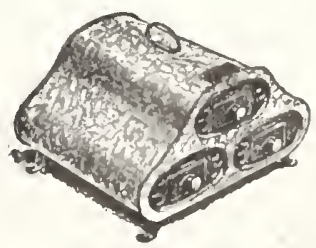

$(\mathbf{w h})$ 
Parcel Post charges where named are for shipment up to and including third zone; for other zones, please add additional postage.

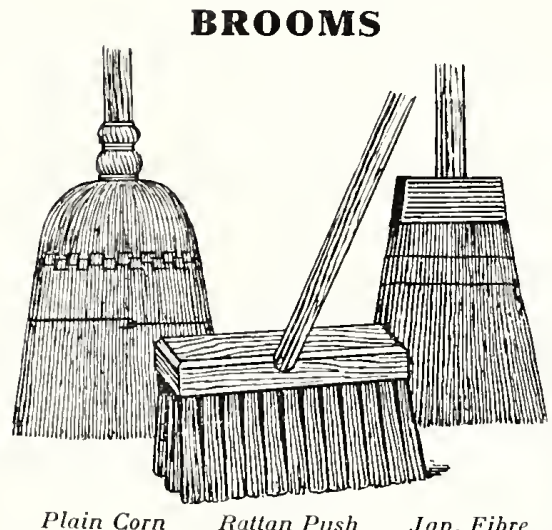

Plain Corn Ratlan Push Jap. Fibre

Each

No. 230. Japanese Fibre..........\$1.35

No. 8 Corn and Rattan mixed ...... $\quad .90$

Golf Greens (Birch) (Doz., \$2.75).....

No. 7. Plain Corn, extra quality..... $\quad .90$

\section{ROAD BRUSHES} (With Handles)

No. 271. Rattan Push, 14-in....... \$1.10

No. 0286. Bass or Cocoa Push, 14-in. . 1.25

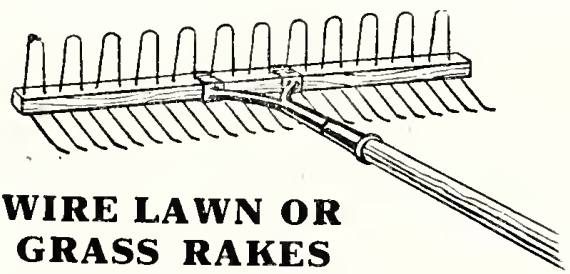

Made of heavy tinned steel wire. 124R -24 tooth. .

No. $342 \mathrm{H}-42$ tooth

.$\$ 0.70$

1.35

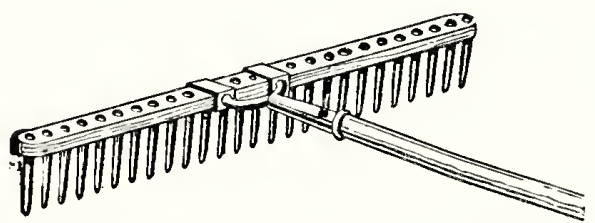

OLE OLSEN LAWN RAKE

Made of the best hard wood; well braced; teeth set close together.

26 tooth, hickory wood.

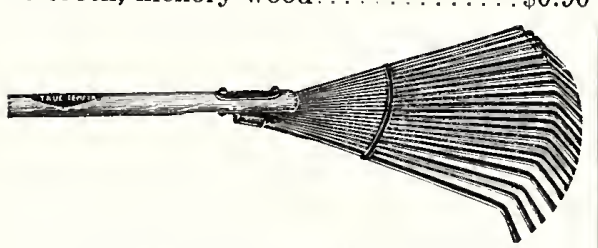

STEEL BRUME RAKE

Spring steel teeth; will remove the smallest leaves and litter. Price, $\$ 1.00$ each.

\section{AUTOMATIC LAWN RAKE}

Self cleaning.

26 tooth, wood

38 tooth, wood

25 tooth, wire

$\$ 1.50$

1.75

\section{WOODEN RAKES}

Ames, 37X, 24 tooth, steel bows; for

lawns...................... $\$ 1.25$

Ames, 14 tooth, wood bow; for hay ..... 1.00

Wire Braced. 20 tooth, lawn...... $\quad .60$

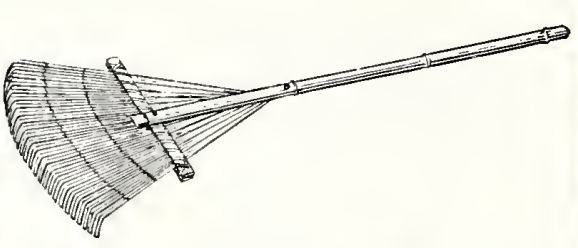

\section{JAPANESE BROOM RAKE}

Made of split bamboo; cleans the lawn or grass plot as completely as though swept with a broom.

18-inch, with bamboo handle. . . . . . $\$ 0.45$ 18-inch, with hardwood handle ....... .75 24 -inch size, with bamboo handle ..... 1.00 30 -inch size, with hardwood handle. . 1.25

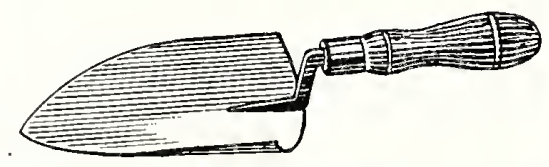

JOHNSON TROWEL, NO. 211

These are made of one-piece steel blade and shank; equal to the imported trowels. 5 -inch .....\$0.60|6-inch ......\$0.65 No. D. S. T. STEEL SHANK TROWEL

Many prefer these as they are somewhat longer in blade and handle, making a very practical tool. $75 \mathrm{c}$. each; doz., $\$ 8.50$.

\section{CLEVES A NGLE TROWEL}

5-inch, 15c. | 6-inch, 20c. | 7-inch, 25c.

\section{NEVERBREAK TROWEL}

No. 0. 6-in. heavy steel. Each, 12c.; $\$ 1.25$ per doz.; per gross, $\$ 11.00$.

If trowels are wanted by P. P., add 10c. each for postage.

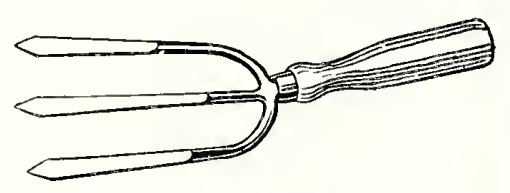

\section{WEEDERS}

Eureka Weeding Fork (see cut above), short handle, 45c. each (by parcel post $55 \mathrm{c}$.); doz., $\$ 5.00$; long handle, $65 \mathrm{c}$. each.

Eureka Weeder, short handle, 45c. each (by parcel post, 55c.); doz., $\$ 4.50$; long handle, 65c. each.

Magic Weeder, small, No. A, 18c. each (by parcel post, 25c.); per doz., $\$ 2.00$; No. B, medium, 25c. each; doz., $\$ 2.75$; No. F, medium, 65c. each; No. H, large, $\$ 1.10$ each.

Excelsior Weeder. 10c. each (by parcel post, 15c.); doz., $\$ 1.10$.

Excelsior Weeding Fork. 10c. each (by parcel post, 15c.); doz., $\$ 1.10$.

No. 1, $3 \mathrm{~W}$ Steel Weeder, 50c. (by parcel post, 60c.).

Hazeltine Weeder. 30c. each (by parcel post, 40c.); doz., $\$ 3.00$.

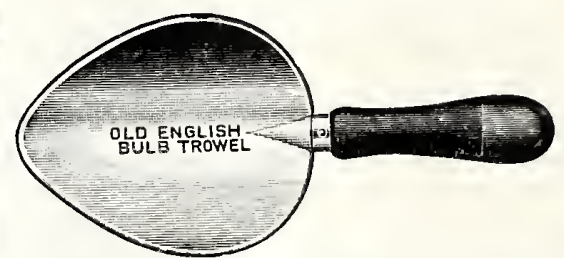

ENGLISH BULB TROWEL

Heart-shaped blade, $43 / 4$ inches wide, for planting out bulbs, etc. Price, $\$ 1.15$.

\section{DIBBLES}

By P.P.

$\begin{array}{lr}\text { Iron, wood handle, each. . . . } . \$ 0.65 & \$ 0.75 \\ \text { Brass, wood handle, each.... } & .85\end{array}$

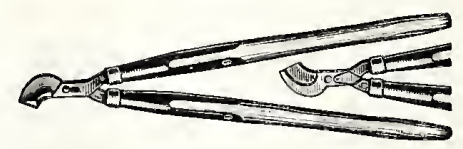

Clyde Draw Cut Lopping Shear

\section{LOPPING SHEARS}

No. 3 Clyde Lopping. 30 inch handles. Price, $\$ 2.10$.

5402 Clyde Draw Cut Lopping. 30-inch handles. Price, \$3.35.

109 English. Made of finest English steel. Price, $\$ 4.75$.

1 Disston Lopping. $271 / 2$-inch handles. Price, $\$ 2.50$.

3 Disston Bull Dog Lopping. 271/2inch handles. Price, $\$ 2.50$.

Rhodes Double Cut. 24-inch and 28-inch handles. Price, $\$ 4.75$.

\section{TIFFANY LOPPING SHEARS}

No. 2. All steel. 24-inch long. Price, $\$ 3.50$ (by parcel post, $\$ 3.65$ ).

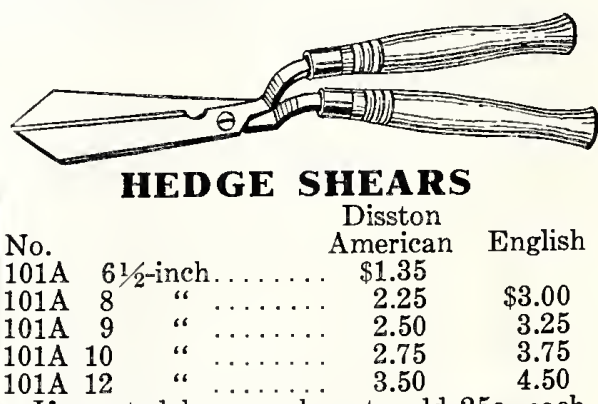

If wanted by parcel post, add 25c. each for postage.

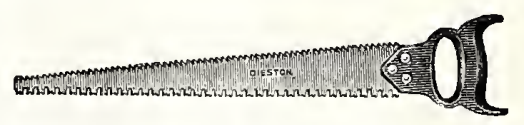

\section{DISSTON PRUNING SAWS}

No. 18 -inch. Double edge......... $\$ 1.60$
41.65

4. 20-inch. Double edge......... 1.85

7. 16-inch. Single edge. . . . . . 1.40

7. 18-inch. Single edge......... 1.60

7. 20-inch. Single edge . . . . . . . 1.65

7. 22-inch. Single edge.......... 2.00

50. 14-inch. California pattern, cres-

cent-shaped blade.......... 1.10

If wanted by parcel post, add $15 \mathrm{c}$. each for postage. 
Parcel Post charges where named are for shipment up to and including third zone; for other zones, please add additional postage.

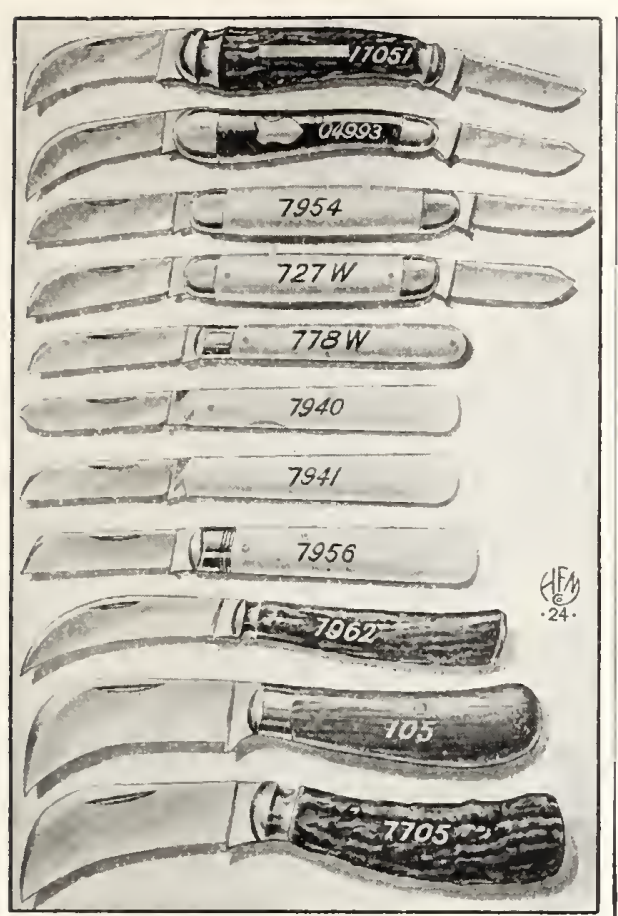

HORTICULTURAL KNIVES

A good knife is an essential to every gardener and florist. Our knives are all of the best steel and guaranteed to give good satisfaction.

No.

\section{WOSTENHOLM ENGLISH} 7705 Pruning, 1 blade, stag handle,

7940 Budding, 1 blade, white handle. 2.50

7941 Budding, 1 blade, white handle. 2.75

7954 Budding, 2 blades, white handle. 2.75

7956 Budding, 1 blade, white handle. 3.00

7962 Pruning, 1 blade, stag handle.. 2.00

17051 Pruning, 2 blades, stag handle.. 3.00 AMERICAN MAKE

105 Pruning, 1 blade, cocoa handle. $\$ 1.00$ $727 \mathrm{~W}$ Budding, 2 blades, white handle. 1.15 04993 Budding and Pruning, 2 blades, ebony or stag handle $\ldots . . . .1 .15$

Florists Favorite, 1 blade, white handle. $\quad .90$ GRAFTING WAX

$1 / 4 \mathrm{lb}$., 15c.; $25 \mathrm{c}$. per $1 / 2 \mathrm{lb}$.; $1 \mathrm{lb}$., $45 \mathrm{c}$. (by parcel post, $55 \mathrm{c}$.).

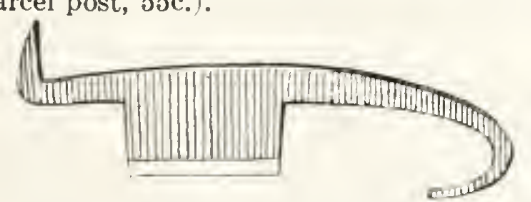

GRAFTING TOOL

Made of best steel, for grafting trees, etc., each $\$ 1.60$ (by parcel post, $\$ 1.70$ ).

PRUNING GLOVES

No. 280 Horse Hide, with Gauntlets,

lined, per pair

No. 225 Horse Hide, with Gauntlets,

not lined, per pair...............

No. 228 Horse Hide, no Gauntlets,

not lined, per pair.................

lined, per pair................. 1.50

If wanted by parcel post, add 10c. per pair for postage.

\section{TREE PRUNERS}

Disston's Little Giant Pruner. . . . \$2.00

Disston's Little Giant. With saw attachment.

No.111. Disston's Adjustable Pruning Saw.

The above prices are for Pruner without rope or pole.

\section{TELE GRAP H TREE PR UNER}

Removable blade, which can be renewed when worn out. Price, $\$ 2.00$ (by parcel post, $\$ 2.15)$. (Extra blades, 35c. each).

\section{CLYDE TREE TRIMMER}

No. 5407. With pole and removable cutting blade, complete.

6 feet.

8 feet

$\$ 2.25$

10 feet

2.50

12 feet

2.75
3.00

14 feet

3.25

Extra Blades for Clyde Pruners, 20c. each.

None of the above Tree Pruners, except the Clyde are equipped with poles or ropes.

Poles for Tree Pruners.

12 feet long, $1 \frac{1}{4}$ inches diameter.

4 feet long, 11/1 inches diameter

Clyde Pruners or Poles are not mailable.

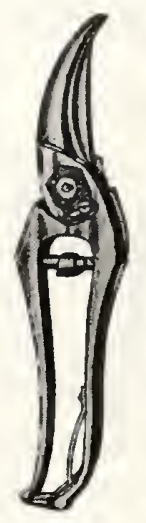

Michell

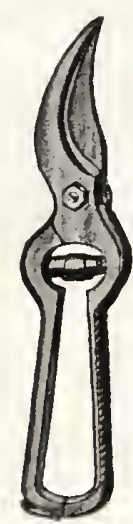

5945
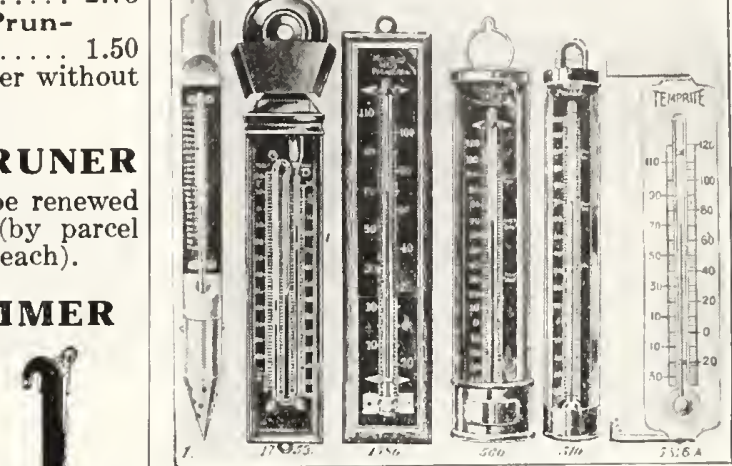

THERMOMETERS

No. 1753. Maximum and Minimum. Registering the coldest and the warmest points during the previous night. $10 \mathrm{in.}$ black tin case, each, $\$ 4.00$.

Tested Grade. These are accurate and may be depended upon. Each Doz. No. 506- 8 in., Tin Case . . . \$0.65 \$7.00 No. 510-10 in., Tin Case... $.75 \quad 8.00$ No. 556- 8 in., Greenhouse . . $1.00 \quad 11.50$ No, 560-10 in., Greenhouse. . 1.2514 .00 No. $652-8$ in., Copper Case. 1.75 No. 656-10 in., Copper Case. 2.00 No. 1582- 8 in., Wood Back. . 1.75 No. 1586-10 in., Wood Back . 2.00 No. 5127- 8 inch Temprite Greenhouse white enamel, red column. $\$ 1.00$ each: doz., $\$ 10.00$.

No. $5316 \mathrm{~A}-8$ inch Temprite Window or Wall; white enamel, red column. $90 \mathrm{c}$. each; doz., $\$ 10.00$.

No. 50 -Brass case, nickel-plated; scale in glass tube, $\$ 2.00$.

HOTBED THERMOMETER

No. 20450-Iron Point, oxidized finish $\$ 2.00$ THERMOSTATS

Furnished complete with the exception of wire, battery and bell. All brass.

Price, f. o. b. Philadelphia.

G. H. 3. Not water proof ........ $\$ 10.50$ $\$ 16.00$

Price, f. o. b. factory.

G. H. 3. Not water proof ....... $\$ 10.00$ G. H. 4. Water proof

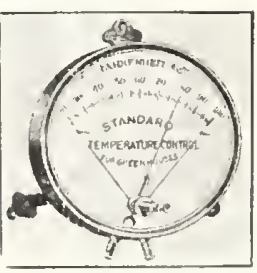

If Pruning Shears are wanted by parcel post, add 10c. each for postage.

No.

100 Michell, 9-inch

5945 Elbersmit, 9-inch

5695 Elbersmit, $91 / 2$-inch

5668 Elbersmit, $71 / 2$-inch

5668 Elbersmit, $81 / 2$-inch

5668 Elbersmit, 91/2-inch

5720 Elbersmit, $51 / 2$-inch, nickeled

5720 Elbersmit, $61 \frac{1}{2}$-inch, nickeled

1586 French, 7-inch.

$\$ 1.751586$ French, 8-inch

0 Pexto, 9-inch.

50 Pexto, 8-inch

R50 Pexto, 9-inch.

65 Pexto, 9-inch

109 Wiss, 8-inch

Each

$\$ 3.75$

2.50

3.00

1.75

2.00

2.25

1.50

1.75

2.00

2.25

.50

.50
1.10

1.10
1.60

Spiral Springs for any of the above Pruning Shears, 15c. each; per doz., $\$ 1.75$.
3.25

ave

\section{$\$ 15.00$}

\section{No. 200 RECORDING THER-} MOMETER

Can be equipped with either a daily or weekly chart enabling the grower to keep an accurate record of the temperature in his greenhouse during every hour of the day and night; equipped with a high grade clock and ink stylus which marks very accurately. When ordering, state if weekly or
daily record chart is desired. Price, $\$ 40.00$, f. 0 . b. factory.

For removing loose bark from trees prior to spraying. Steel blade may be detached and sharpened.

No. 5 Short handle...

Each P.P.

No. 1 Two-foot handle

$\$ 0.50 \$ 0.60$

1.15 
Parcel Post charges where named are for shipment up to and including third zone; for other zones, please add additional postage.

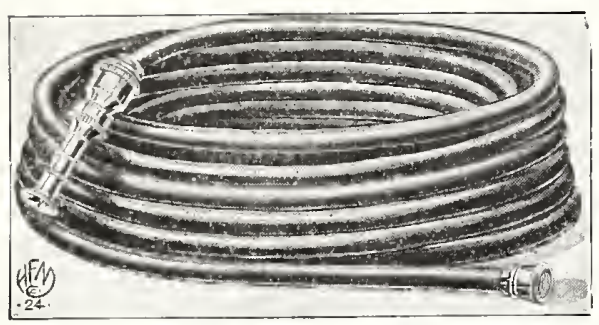

RUBBER HOSE Per ft.

Michell's Special, $1 / 2$ in..

Michell's Special, $3 / 4$ in...

Electric. You cannot kink it. $1 / 2$ in.

Electric, $5 / 8$ in...

Electric, $3 / 4$ in...........................

Emerald Cord. $3 / 4$ in.; in 25 and 50

foot sections only.

Michell's Akron. Flexible, durable,

unkinkable, $3 / 4$ in.

Michell's Magic, $3 / 4$ in...

Spray Pump Hose. Electric, $3 / 8$ in. .

All brands (excepting Emerald Cord) come in reels of 500 feet and sections in any length to that number of feet may be had.

25 - and 50-foot sections of hose coupled free. Smaller sections coupled at the rate of 20 c. per pair for couplings attached.

HOSE WASHERS (Rubber)

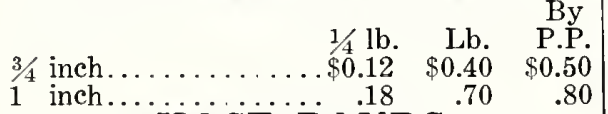

$3 / 4$ inch..
1 inch..

HOSE B̈ANDS

CALDWELL'S

No.

Doz. Gross

8. For 4-ply hose . . . . . . \$0.30 $\$ 3.00$

6. For 3-ply hose ......... . $30 \quad 2.75$

If wanted by parcel post, please add $5 \mathrm{c}$.

per doz., and 15c. per gross for postage.

PLIERS for above, 30c. per pair (by parcel post, 40c.).

SURE GRIP

Can be furnished in $1 / 2$ inch, $5 / 8$ inch and $3 / 4$ inch; either size, $4 \mathrm{c}$. each; doz., 35c. (by
parcel post, $45 \mathrm{c}$.); $\$ 2.50$ per 100 (by parcel post, $\$ 2.75)$.
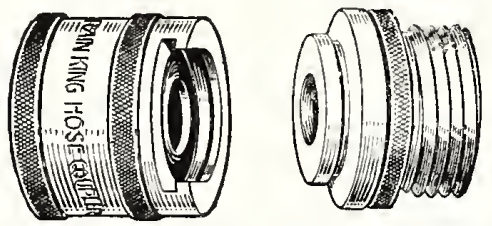

RAIN KING COUPLING

Snaps together instantly; fits nozzles, sprinklers and standard hose connections. 55c. per pair (by P. P., 60c.); doz.; $\$ 6.00$.

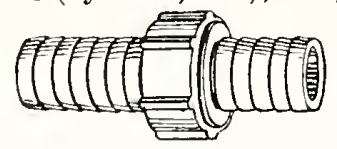

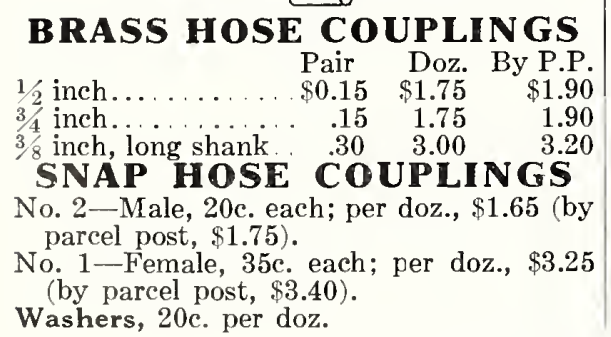

\section{PERFECT \\ HHOSE COUPENGS}

Equipped with a clamp on the male and female part for securing to the hose; no band required; for $1 / 2$ and $3 / 4$ inch hose; mention which is wanted when ordering. 25c. per pair (by parcel post, 30c.); doz. pairs, $\$ 2.75$ (by parcel post, $\$ 3.00$ ).

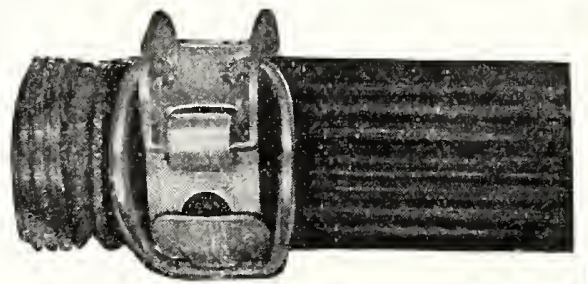

NOSCREW HOSE CLAMP

Installed instantly; no screw driver or tools of any kind required; for $1 / 2$ in., $5 / 8$ in., and $3 / 4$ in. hose. $8 \mathrm{c}$. each; doz., $80 \mathrm{c}$.

\section{HOSE MENDERS}

If wanted by parcel post, add $10 \mathrm{c}$. per doz. for postage. $\quad$ Each Doz. 100 Cooper's, 3/4 in........\$0.10 $\$ 0.90 \quad \$ 6.00$ $\begin{array}{llll}\text { Cooper's, } 5 / 8 \text { in.......... } & .10 & .90 & 6.00 \\ \text { Cooper's, } 1 / 2 \text { in ........ } & .10 & .90 & 6.00\end{array}$ $\begin{array}{llll}\text { Iron, } 3 / 4 \text { in............ } & .10 & .90 & 6.00\end{array}$ PERFECT HOSE MENDERS

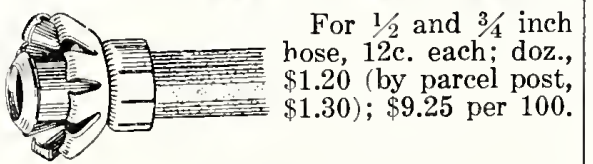

\section{SIAMESE HOSE CONNECTION}

This permits one lead of hose to be diverted in two directions. Additional two-way connections can be used according to the water pressure. $60 \mathrm{c}$. each (by parcel post, 70c.).

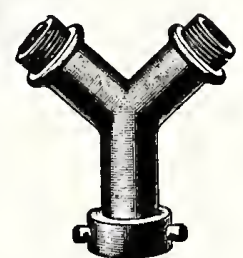

\section{SHUT-OFF CONNECTION}

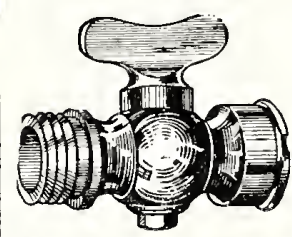

Cast-brass, polished. $3 / 4$-inch male thread on one end, 3 -inch female thread on the other. $\$ 1.00$ each (by P.P. $\$ 1.10)$.

\section{BINKS NOZZLE}

Made of aluminum, with brassface;equipped with interchangeable sprays, coarse and fine. $\$ 2.75$ each (by parcel post, $\$ 2.85$ ).

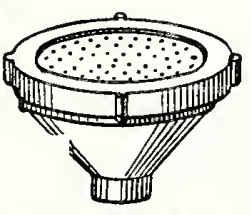

\section{BOSTON SPRAY NOZZLE}

(For 3/4-inch Hose)

Light Copper, $\$ 1.25$ (by parcel post, $\$ 1.35$ ). Heavy Brass, $\$ 1.25$ (by parcel post, $\$ 1.35$ ).

\section{RUBBER APRONS}

For protecting the clothing while watering, etc.; made of extra heavy material; brass eyelets. $\$ 1.80$ each (by parcel post, $\$ 2.00)$.

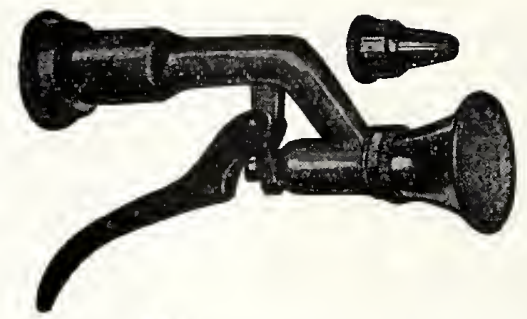

AQUMATIC HOSE NOZZLE

A positive, quick shut-off; made of heavy cast brass. $\$ 1.75$ each (by parcel post, $\$ 1.85$ ).

RAIN KING HOSE NOZZLE

Wear-proof, leak-proof and guaranteed; adjustable from a solid stream to the finest spray. 70c. each (by parcel post, 80c.).

\section{GEM PATTERN NOZZLE}

For $3 / 4$-inch hose. 45c. each (by parcel post, 55c.).

\section{CHAMPION BrasS NOZZLE}

A dandy nozzle for greenhouse use; easily adjusted. 45c. each (by parcel post, 55c.).

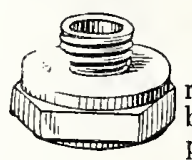

HOSE REDUCERS

Reduces 1-inch pipe to fit regular $3 / 4$-inch hose. All brass. Each, 55c. (by parcel

\section{HYDRANT ATTACHMENTS}

Used for attaching hose to smooth faucets.

No. 2. For small spigot, each, 45c. (by parcel post, 55c.).

No. 3. For large spigot, each, 50c. (by parcel post, 60c.).

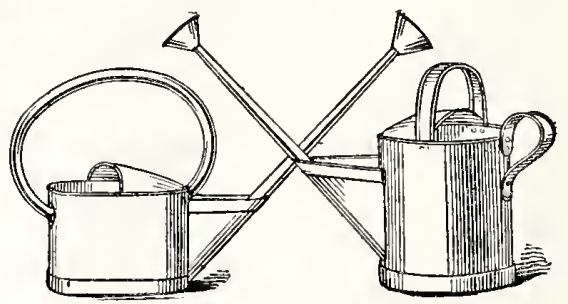

WATER CANS (Wotherspoon)

Galvanized; extra heavy, with long spout and two roses-one coarse and one fine.

Round Oval

4 quart............\$3.75

6 quart............. $4.00 \quad \$ 4.75$

8 quart.............. $4.50 \quad 5.00$

10 quart.............. 5.25

12 quart............. $5.25 \quad 5.75$

16 quart .............. $5.75 \quad 6.25$

4 quart Fern or Low ......... 3.50

Extra Roses for Wotherspoon Watering Cans, either coarse or fine, 50c. each.

IRON CLAD WATER CANS

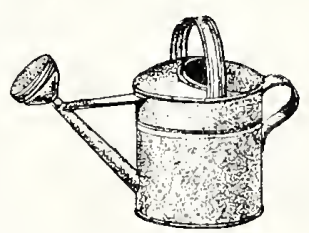

Made of light galvanized iron.

4 quart..... $\$ 0.80$

6 quart...... .90

8 quart....... 1.00

10 quart. . . . 1.10

12 quart...... 1.20

16 quart...... 1.75 
Parcel Post_charges where named are for shipment up to and including third zone; for other zones, please add additional postage.

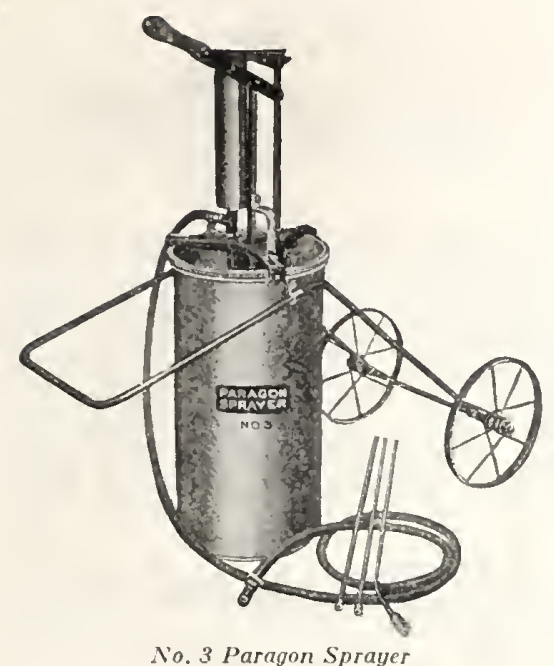

PARAGON SPRAYERS

Especially desirable for the reason that it is not necessary to strain the material. Excellent for applying whitewash.

No. 0-Capacity 31/2 gallons; equipped with $4 \mathrm{ft}$. of hose, one-3-ft. spray pipe and 3 spray nozzles. $\$ 11.00$.

No. 1-With a 6-gallon reservoir, $5 \mathrm{ft}$. of hose, $5 \mathrm{ft}$. of spray pipe and 3 nozzles. $\$ 16.00$.

No. 3-Equipped with a 12-gallon tank mounted on a truck, $71 / 2-\mathrm{ft}$. spray pipe, 3 nozzles and $10 \mathrm{ft}$. of hose. $\$ 21.00$. Without truck, $\$ 18.00$. We can also supply this sprayer with single wheel at same price.

No. 4-Capacity, 28 gallons; mounted on a two-wheel truck; $10 \mathrm{ft}$. of spray pipe, 20 $\mathrm{ft}$. of hose and 3 nozzles. $\$ 37.00$.

No. 5-Capacity, 50 gallons; equipped with $25 \mathrm{ft}$. hose, one 10 -ft. extension pipe, one 3-way spray nozzle and one single spray nozzle, no truck. $\$ 42.50$.

B 41. Extra Washers for pump plungers for Paragon Sprayers, 25c. each.

We can also supply parts for Paragon Sprayers; price list on application.

\section{GOULD SPRAY PUMPS}

This make of spray pump has been favorably regarded among gardeners, farmers and fruit growers for years.

Pomona. No. 1744. Plain barrel pump. Price, $\$ 19.80$.

Pomona. No. 1744. Outfit $\mathrm{C}$, with agitator, $15 \mathrm{ft} .1 / 2$-in. special spray hose and 1 Mistry, Jr. Nozzle. Price, \$25.45.

Pomona. No. 1744. Outfit D, with agitator, two $15 \mathrm{ft}$. leads of special 1/2-in. spray hose and 2 Mistry, Jr. Nozzles. Price, $\$ 31.05$.

Fruitall. Fig. 1188. Plain barrel pump. Price, $\$ 10.80$.

Fruitall. Fig. 1188 (Outfit C), with agitator, one 15-foot lead of $1 / 2$-inch special spray hose and 1 Mistry, Jr. Nozzle. Price, $\$ 16.45$.

Fruitall. Fig. 1188 (Outfit D), with agitator, two 15 -foot leads of $1 / 2$-inch special spray hose and two Mistry, Jr. Nozzles. Price, \$22.05.

Barrels for holding spray solution, 50 gal. capacity, $\$ 6.50$.

Truck with $31 \frac{1}{2}$ inch tire wheels, $\$ 17.50$.

\section{AUTO SPRAY}

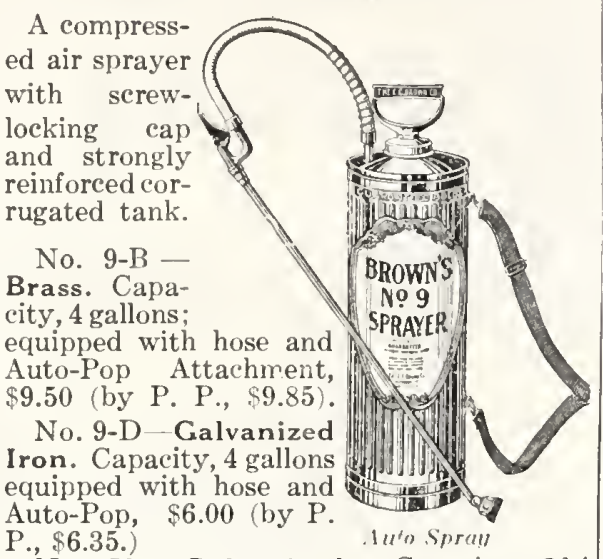

No. 50. Galvanized. Capacity, $21 / 2$ gallons; equipped with hose and Auto-Pop, $\$ 5.25$ (by P. P., $\$ 5.50$ ).

Auto-Pop Nozzle Attachment; controls the flow instantly by a pressure of the hand. When Auto-Pop Attachment is purchased separately:

Plain, \$1.35 each (by parcel post, \$1.45). Complete with hose, $\$ 2.25$ (by parcel post, $\$ 2.40$ )

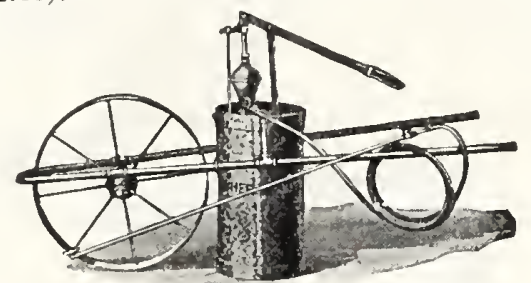

WHEELBARROW SPRAYER

Extreme width, 18 inches; narrow enough to go through the aisles of a greenhouse; 24-in. wheel with a 3 -in. tread, making it easily handled over soft and rough ground. Pump has $1 \frac{1}{2}$ in. diam. cylinder, with adjustable stroke. Equipped with 12-gal. galvanized tank, 10-ft. of hose, 4 -ft. extension pole, nozzle and shut-off valve, $\$ 32.00$.

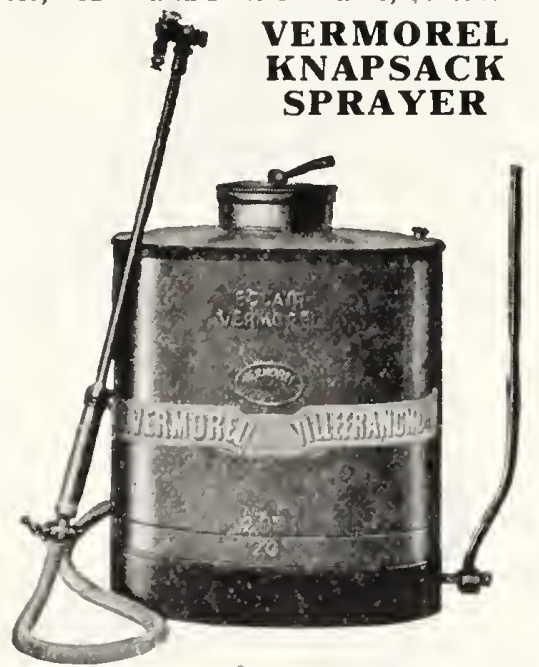

A new knapsack sprayer which works on the compressed air principle. Compact in construction and light in weight, so that it can be easily carried around. Price, $\$ 18.50$ (by parcel post, $\$ 19.00$ ).

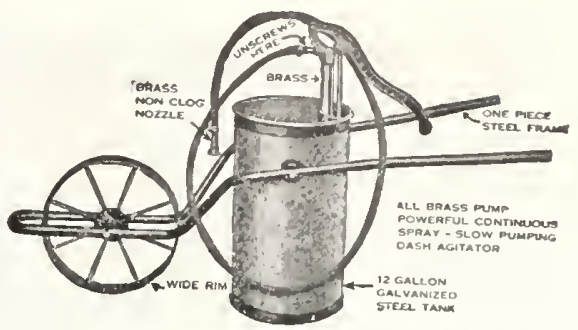

\section{No. 50 WHEELBARROW SPRA YER}

Adapted for spraying vegetable crops, flowers, orchards, etc., also for spraying disinfectants. Steel frame; galvanized tank; all brass pump; all working parts brass; 8 feet of hose. Price, $\$ 14.00$.

Price with brass tank, $\$ 21.50$.

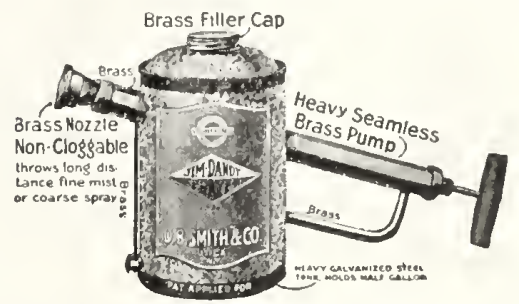

JIM DANDY SPRAYER

Adapted for spraying vegetables and flowers, small fruits, ete.; also valuable for spraying disinfectants in buildings. Price, $\$ 3.25$ (by parcel post, $\$ 3.45$ ).

\section{BUCKET SPRAY PUMP}

This is made entirely of brass except the foot rest, bucket fastener and hand grip. The price below does not include bucket, but includes nozzle and $31 \frac{1}{2}$ feet of $3 / 8$-inch hose.

No. 689. Perfect Success (with bucket fastener), $\$ 8.00$ (by parcel post, \$8.25).
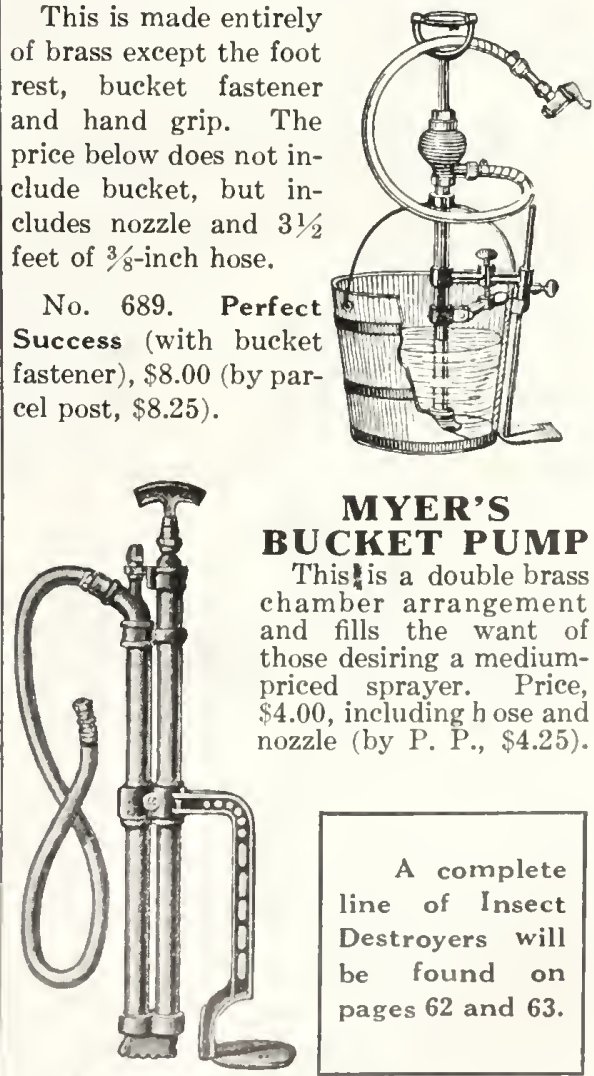

MYER'S BUCKET PUMP

This is a double brass chamber arrangement and fills the want of those desiring a mediumpriced sprayer. Price, $\$ 4.00$, including h ose and nozzle (by P. P., $\$ 4.25$ ).

Myer's Pump 
Parcel Post charges where named are for shipment up to and including third zone; for other zones, please add additional postage.

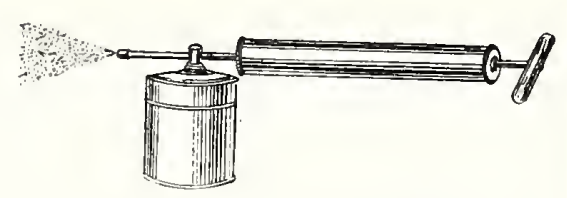

HAND SPRAYERS

Michell's (Compressed Air). See cut. Tin, each, 90c. (by P.P., \$1.10); Brass, each, $\$ 1.80$ (by P. P., $\$ 2.00$ ).

Cyclone Sprayer. Similar to the above but with no automatic air reservoir.

No. 112, tin, 45c. (by P. P., 55c.).

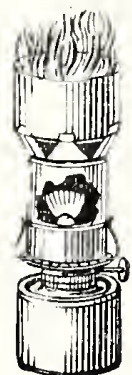

\section{VAPORIZIN G}

\section{LAMP}

Practical and indestructible; all metal; burns kerosene; used for dispensing fumes of Nikoteen and other preparations of this sort. 70c. each (by P. P., 80c.); 6 for $\$ 3.75$ (by P. P., \$4.00); $\$ 7.25$ per doz. (by P. P., $\$ 7.75$ ).

Vaporizing Lamp

\section{FUMIGATORS}

Perfection-Fitted with a water tank to prevent burning out.

No. Feet

1 for house, $12 \times 40$

2 for house, $15 \times 100$.

3 for house, $20 \times 100$

5 for house, $20 \times 150$.

Each

. $\$ 7.00$

. 8.50

.10 .50

16.00

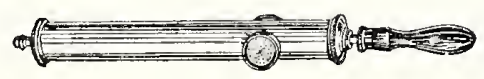

\section{HEA VY BRASS SYRINGES}

\begin{tabular}{|c|c|c|c|}
\hline Diam. & \multicolumn{3}{|c|}{ Length } \\
\hline No. & in. & & Price \\
\hline 99. $1 \frac{1}{2}$ & 18 & 1 spray &.$\$ 3.00$ \\
\hline 101. & 14 & 2 sprays & 3.50 \\
\hline 101A. $11 / 2$ & 16 & 2 sprays. & 4.50 \\
\hline 110. $13 / 4$ & 20 & 2 sprays & 9.00 \\
\hline 120. $13 / 4$ & 20 & Adjustab & 9.50 \\
\hline
\end{tabular}

Py. $\$ 3.25$ 3.75 4.75 9.25 120. $13 / 4 \quad 20$ Adjustable... 9.50

9.75

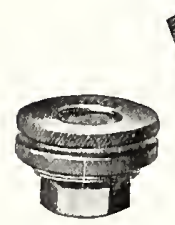

1688

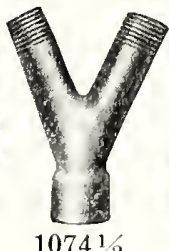

$10741 \%$

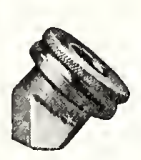

1691

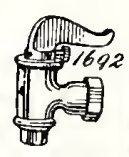

1692
SPRAY NOZZLES(3/8-in. Thread

Mistry, Jr, Fig. 1688, Straight Each Mistry, Jr., Fig. 1691, Angle style . . . 1.10 Fig. 10741/2, Y connection for making a double spray head nozzle........ .35

Fig. 1692, Bordeaux . . . . . . . . . . 1.35

If nozzles are wanted for $3 / 4$-in. hose connections, add $60 \mathrm{c}$. to above prices for Fig. 966 combination.
STOTT'S SPRAY NOZZLES

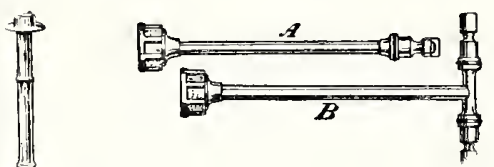

\begin{tabular}{r|r} 
Each & Each \\
A. Single...\$1.50 & B. Double. .\$2.50
\end{tabular}

EXTENSION PIPES, Etc.

For reaching into trees $(3 / 8$-inch threads).

Bamboo, brass lined, $8 \mathrm{ft} \quad$ Each

Bamboo, brass lined, $12 \mathrm{ft}$.... 5.00

${ }^{*}$ Brass, 2 ft., for Auto Sprays ... $\quad .55$

Pet Cock, for extension pipes . . 1.10

*Paragon Extension, $21 / 2 \mathrm{ft}$... .60

${ }^{*}$ If wanted by P. P., add 10c. for postage.

No. 1

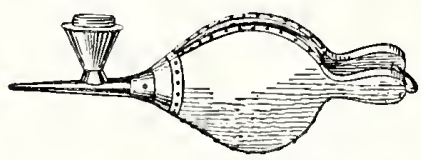

No. 2

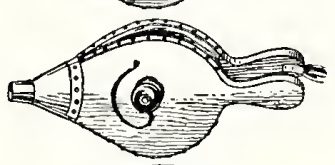

No. 3

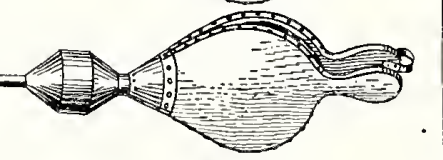

BELLOWS

No. 1. Small Single Cone..... $\$ 3.00$

No. 2. Sulphur Bellows....... 3.75

No. 3. Large Double Cone.... 6.25

Large Single Cone.... 4.50
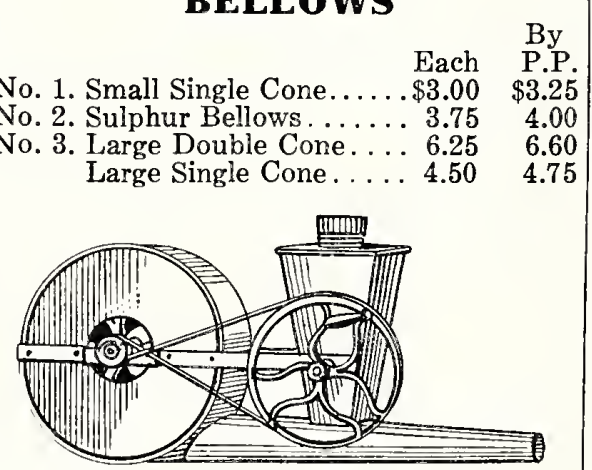

\section{SULPHUR BLOWER}

For distributing sulphur and insecticides of various kinds. Made of heavy metal; no wearout to them. $\$ 7.00$ (by P. P., $\$ 7.50$ ).

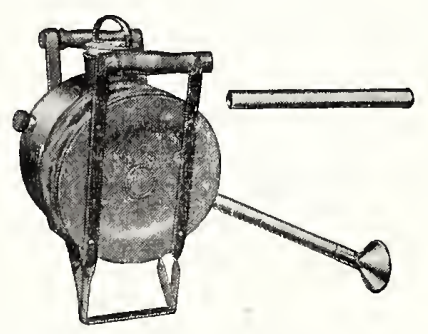

\section{"GREEN" HAND DUSTER}

Capacity, 2 to 4 pounds; powerful bellows; 30 in. extension with spreader. Price, $\$ 5.50$.

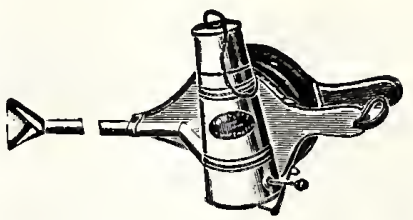

\section{"FAMOS" HAND DUSTER}

An ideal machine for those who need a small, but efficient duster; of light, compact and sturdy construction; equipped with extension pipes 24 inches in length. The fan shaped spreader can be adjusted to throw dust on the under side of foliage or at any angle desired; especially adapted for applying sulphur. Capacity, one pound. Price, $\$ 5.00$.

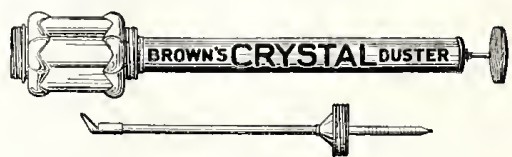

\section{BROWN'S CRYSTAL DUSTER}

A new type duster recommended for use in dusting truck crops in the garden, flower beds, etc. The glass jar feature enables the operator to see the amount of dust in the container; equipped with a long extension and adjustable nozzle. Capacity, one quart. Price, $\$ 1.35$.

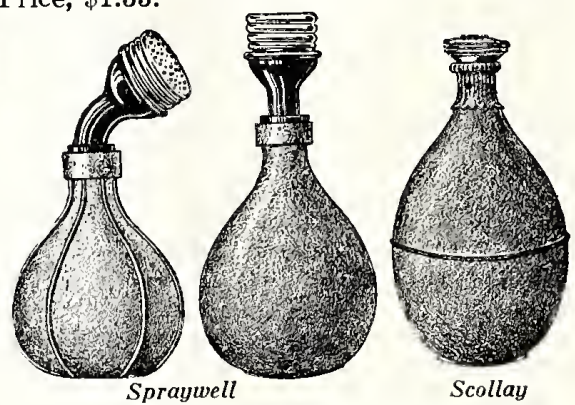

RUBBER SPRINKLERS

For sprinkling cut flowers, seedlings, etc. Spraywell style in either straight or crook neck.

No. $\quad$ Each

1. Spraywell Style- 6 oz. capacity.. $\$ 0.75$

2. Spraywell Style- 8 oz. capacity.. $\quad .85$

3. Spraywell Style-10 oz. capacity.. 1.00

1. Scollay -10 oz. capacity ......... 1.35

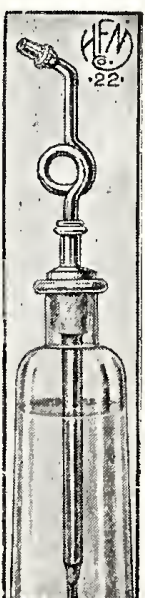

If wanted by parcel post,

\section{MISTO BOTTLE SPRA YER}

For applying water to cut flowers, funeral and other design work; makes a fine mist, avoiding all drip; made of metal, nicely nickeled. Price, without bottle, $85 \mathrm{c}$. each (by P. P., 95c.); 6 for $\$ 5.00$ (by P. P., $\$ 5.25$ ). add 10c. each for postage. 
Parcel Post charges where named are for shipment up to and including third zone; for other zones, please add additional postage.

\section{GLAZING POINTS}

Peerless Glazing Points. Nos. 1 and 2 for single-thick glass. No. $2 \frac{1}{2}$ for doublethick glass; 60c. per 1000 (by parcel post, $70 \mathrm{c}$ ); 5000 for $\$ 2.75$ (by parcel post, $\$ 3.00$ ).

Pincers. For driving Peerless Points, $\$ 1.00$ per pair (by parcel post, $\$ 1.10$ ).

Siebert's Style Points (Zinc). Three sizes, $5 / 8,6 / 8$ and $7 / 8$ inch, $40 \mathrm{c}$. per lb. (by parcel post, 50c.); 5 lbs., $\$ 1.90$ (by parcel post, $\$ 2.10)$; $\$ 3.70$ per 10 lbs. (by parcel post, $\$ 4.00$ ).

Zinc Nails. $5 / 8,6 / 8$ and $7 / 8$ inch, 35c. per $\mathrm{lb}$. (by parcel post, 45c.); 5 lbs., $\$ 1.60$ (by parcel post, $\$ 1.80$ ).

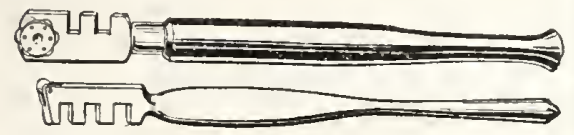

\section{GLASS CUTTERS}

No. 8. Small Diamond. Ebony handle .................... \$4.25 No. 8A. Large Diamond. Mahogany handle ................ 5.50 Single Wheel. Steel (doz., $\$ 1.50$ )... .15 6 Wheel. Adjustable............ .35

\section{PUTTY DISTRIBUTOR}

The best appliance for distributing putty. Each, $\$ 1.50$ (by parcel post, \$1.60).
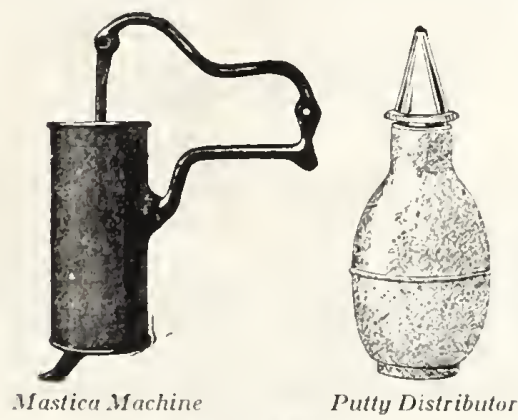

MASTICA

Mastica is a prepared putty, which retains its soft qualities for a long while, making it possible to replace broken lights of glass readily. Per gal., $\$ 2.25$; $\$ 11.00$ per 5 gals.

Mastica Machine. Each, $\$ 2.75$ (by parcel post, $\$ 2.90)$.

\section{BLACK GLAZING CEMENT (Masticote)}

For waterproofing greenhouse gutters, roofs, etc.; also for making sash bars watertight; gives splendid satisfaction. Apply with a mastica machine. Per gal., \$1.50; $\$ 7.25$ per 5 gals.; $1 / 2$ bbl. (35 gals.), $\$ 1.10$ per gal.; bbl. (55 gals.), \$1.05 per gal.

\section{KEYSTONE LIQUID GLAZING PUTTY}

Especially adapted for glazing wood and metal sash; can be applied with a putty bulb or gun, making a perfectly watertight job. Per gal., $\$ 2.00 ; \$ 9.50$ per 5 gals.; $1 / 2$ bbl. (about 30 gals.), $\$ 1.80$ per gal.; bbl. (about 50 gals.), $\$ 1.60$ per gal.

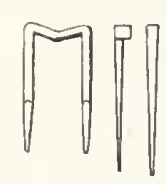

123

No. 1. Pécrless.

No. 2. Stebert's.

No. 3. Zinc Nails.

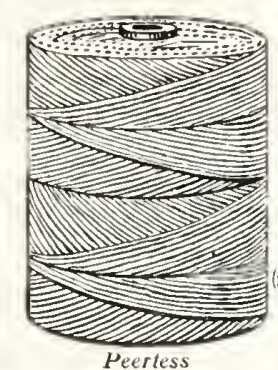

GREENHOUSE

WHITE PAINT

Undoubtedly the best and most economical white paint on the market today. Per gal., $\$ 3.50 ; \$ 17.25$ per 5 gals.; bbl. (about 50 gals.), $\$ 3.40$ per gal.

\section{PEERLESS}

GLASS REPAIR CLAMP

Will not rust; will save lights of glass worth from 40 cents to 50 cents each. Price, $\$ 1.30$ per 100 (by parcel post, $\$ 1.40$ ).

\section{DAYLIGHT GLASS CLEANER}

For taking off whitewash shading, etc. The most powerful cleaner on the market. Apply with a brush, leave on a few minutes and rinse off with cold water.

One gallon will clean about 400 to 600 square feet of glass. Price, per gal., $\$ 2.25$; $\$ 9.00$ per 5 gals.

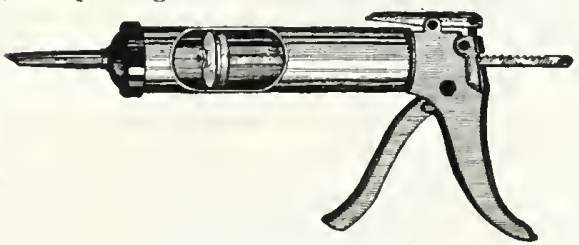

GLAZIT GUN

For applying liquid glazing putty, mastica, etc. Each, $\$ 4.50$ (by P. P., $\$ 4.75$ ).

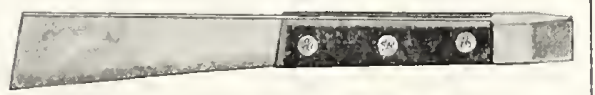

\section{GLAZING CHISEL}

Made of fine quality steel. Each, $\$ 1.20$ (by P. P., $\$ 1.35$ ).

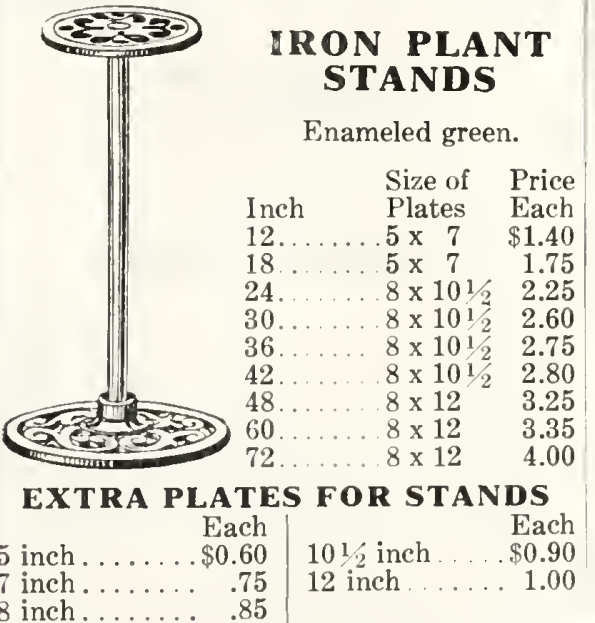

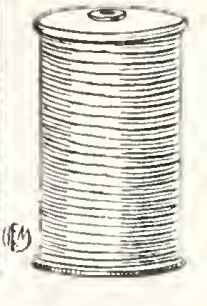

Rafiatape
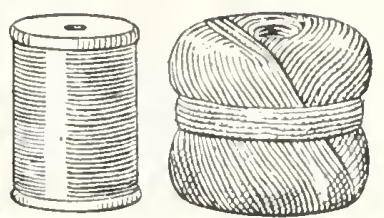

Silkaline

Green Sea Island

\section{TWINES, Etc.}

If Twine is wanted by parcel post, add 10c. per lb. for postage.

No. 108. White Cayuga Twine.

Per ball Per lb.

Medium.............. $\$ 0.30 \$ 0.55$

No. 208. White Cayuga Twine.

Heavy.................

ute, 2-ply and 3 -ply. 5 lbs.,
$\$ 1.25 ; \$ 2.45$ per 10 lbs....... . .

Linen Bouquet, 3 lbs., $\$ 2.00 \ldots \quad .12 \quad .70$

Green Sea Island, 5 lbs., $\$ 3.10$. $\quad .10 \quad .65$

Special White Cotton, 3-ply... . $\quad .10 \quad .50$

Tarred. For mat making...... . .30

Tarred Sisal. For fodder...... $\quad .15$

Binder (bale lots, 18c. per lb.)... $\quad .20$

No. 6. Express. Very heavy.... . .25

No. $41 / 2$. Japanese Twine.

Medium heavy.......... $\quad .27$

Green Silkaline. F, fine; FF, medium; FFF, coarse; per spool, 30c.; $\$ 2.35$ per lb. (8 spools).

Everbest Florists' Thread. A green linen thread. Per spool, 20c.; $\$ 1.25$ per lb.; 5 lbs., $\$ 5.75 ; \$ 11.00$ per 10 lbs.

\section{FLORISTS' PEERLESS TWINE}

For tying up flower boxes, designs, etc.

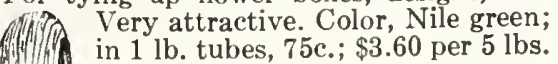

\section{RAFFIA}

We make a careful selection of long broad strands for our trade.

Natural Color. 30c. per lb. (by P. P., 40c.); 5 lbs., $\$ 1.25$ (by P. P., \$1.45).

Green Raffia. 70c. per lb. (by P. P., 80c.); 5 lbs., $\$ 3.25$ (by P. P., \$3.45).

\section{RAFFIATAPE}

This article is made of a composition of paper and linen, and is tremendously strong. It is about $1 / k$-in. wide, and is put up in 250yd. spools or reels. There is no waste, as the reel permits it to be hung from a button hole, and it can be used as needed. Color, Nile green. Per bolt of 250 yards, $80 \mathrm{c}$. (by parcel post, $90 \mathrm{c}$.); 6 bolts, $\$ 4.50$ (by parcel post, $\$ 4.75$ ). 
Parcel Post charges where named are for shipment up to and including third zone; for other zones, please add additional postage.

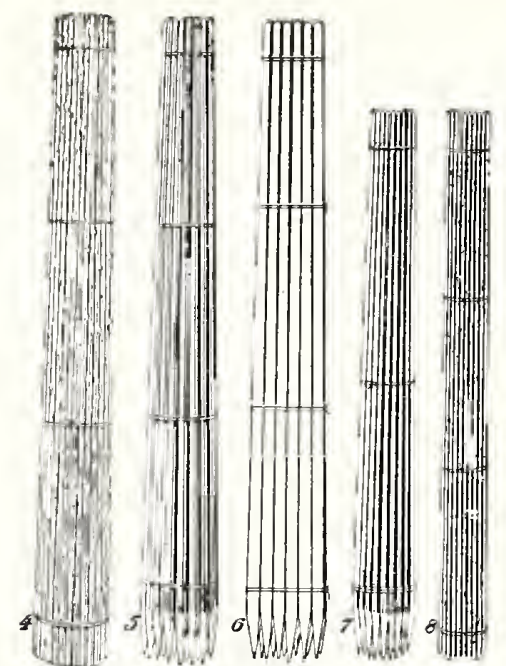

Key to above illustration: No. 4, Japanese Cane, natural; No. 5, Dahlia; No. 6, Square; No. 7, Tapering; No. 8, Japanese Cane, green.

\section{PLANT STAKES}

No. 10 Steel Wire, Galvanized

\begin{tabular}{|c|c|c|c|c|}
\hline & & Doz. & 100 & 1000 \\
\hline foo & $\mathrm{t}$. & $\$ 0.15$ & $\$ 0.95$ & $\$ 6.50$ \\
\hline $1 / 2 "$ & & .18 & 1.15 & 8.00 \\
\hline “ & & .25 & 1.35 & 10.00 \\
\hline $1 / 2$ & & .30 & 1.60 & 11.00 \\
\hline " & $\cdot$ & .35 & 1.70 & 12.00 \\
\hline $11 / 2 "$ & & .40 & 1.90 & 13.50 \\
\hline " & & .45 & 2.10 & 15.00 \\
\hline “ & ․ & .55 & 2.50 & 18.00 \\
\hline
\end{tabular}

No. 8 Steel Wire, Galvanized

For staking American Beauty and other strong-growing roses.

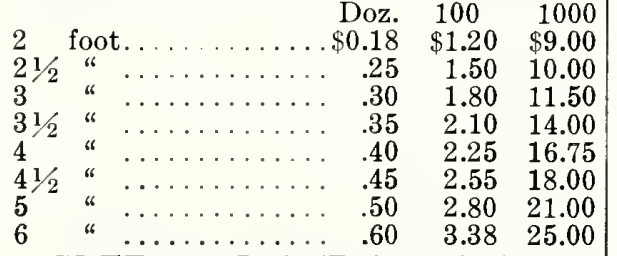

GREEN PAINTED TAPERING PLANT STAKES

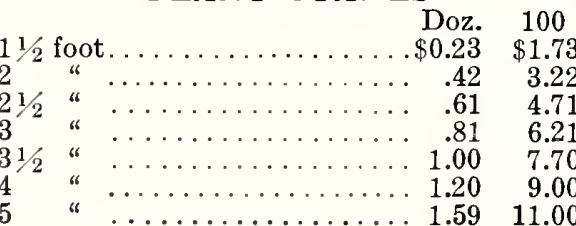
GREEN PAINTED HEAVY OR DAHLIA STAKES

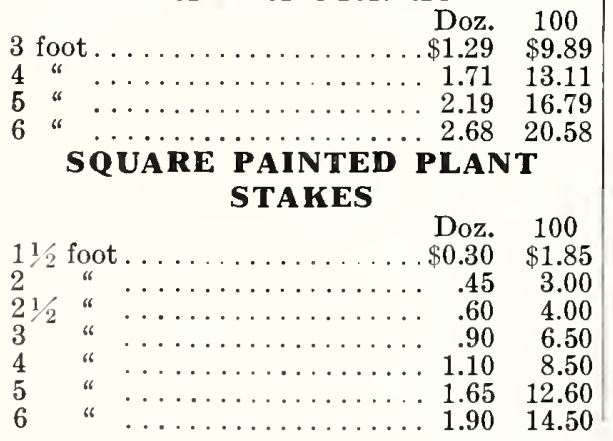

\begin{tabular}{|c|c|c|c|c|}
\hline \multicolumn{5}{|c|}{$\begin{array}{l}\text { HYACINTH STAKES } \\
\text { (Wood) Dyed Green }\end{array}$} \\
\hline & 100 & 1000 & 5000 & 10,000 \\
\hline incl & $\$ 0.15$ & $\$ 0.90$ & $\$ 4.00$ & $\$ 7.75$ \\
\hline “ & .25 & 1.40 & 6.50 & 12.50 \\
\hline " & .35 & 2.10 & 10.00 & 19.00 \\
\hline
\end{tabular}

JAPANESE CANE STAKES

These are very attractive for all purposes of plant staking; thin and very strong.

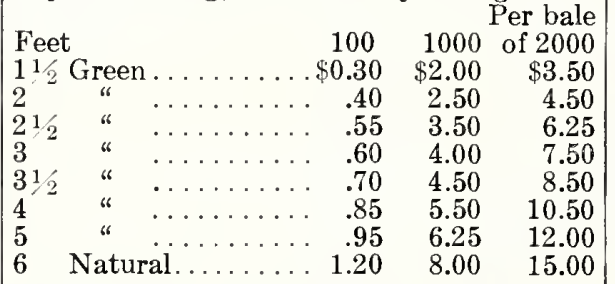

\section{CHINESE TONKIN BAMBOO} STAKES

A heavy, substantial stake for Dahlias, Ivy, young trees, etc.

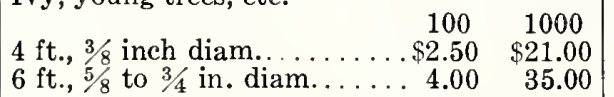

\section{STAKE FASTENERS}

Everlasting Style. Heavy, $\$ 1.35$ per 500 (by parcel post, $\$ 1.45$ ); 1000 for $\$ 2.50$

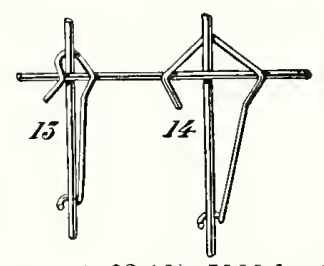
(by parcel post, $\$ 2.65) ; \quad \$ 11.25$ per $5000 ; 10,000$ for $\$ 20.00$. (See illustration No. 14.)

Eureka Style. Light, $\$ 2.00$ per 1000 (by parcel

post, $\$ 2.10$ ); 5000 for $\$ 9.50$ (by parcel post, $\$ 9.70) ; \$ 17.50$ per 10,000 . (See illustration No. 13.)

\section{LIGHTNING WIRE PLANT TIE}

Takes the place of twine; can be used more quickly and many times. Per 1000 , $\$ 2.00$ (by parcel post, $\$ 2.15) ; \$ 9.00$ per 5000 (by parcel post, $\$ 9.35$ ); 10,000 for $\$ 18.00$.

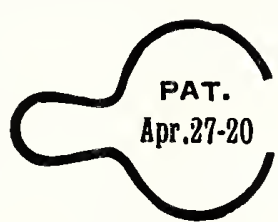

Lightning Tie

\section{POLES FOR TREE PRUNERS}

12 feet long, $11 / 4$ inches diameter . . . . \$2.50 14 feet long, $1 \frac{1}{4}$ inches diameter . . . . 2.75

\section{BAMBOO POLES}

Doz.

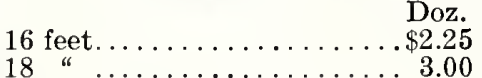

$20 \quad \ldots \ldots \ldots \ldots \ldots \ldots \ldots 3.50$

100

$\$ 13.50$

22.50

Our Garden Tool and Sundries Department we believe to be the most fully equipped of any seed store in the United States. Most every article of real merit for horticultural work will be found here, and of the best quality.
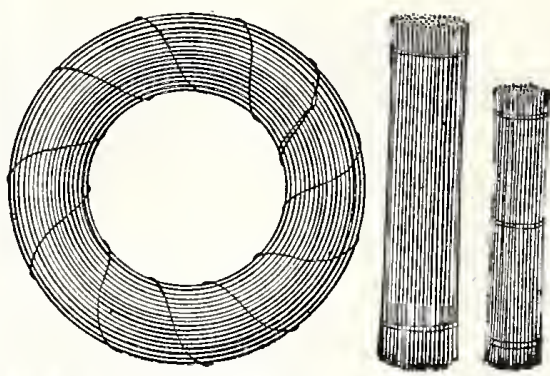

WIRE (Price Subject to Change) Anrealed

No. 16 per 12-lb. stone. . . . . . . . \$1.25

o. 18 per 12 -lb. stone. . . . . . . . . 1.30

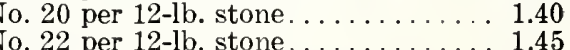

No. 24 per 12-lb. stone............ 1.60

Galvanized

No. 16 per 12-lb. stone. . . . . . . . . . \$1.25

No. 18 per $12-\mathrm{lb}$. stone. . . . . . . . . . 1.40

No. 19 per 12 -lb. stone. . . . . . . . . . 1.45

No. 20 per 12 -lb. stone. . . . . . . . 1.45

No. 22 per 12-lb. stone. . . . . . . . . 1.55

No. 19, Tinned, cut to $81 / 2$ in. long,

10 -lb. box............... 2.00

CUT BOUQUET WIRE

For Stemming Flowers, Etc.

No. 20. Cut, 9, 12 or 18 in. long, 20c. per lb.; per box, 12 lbs., $\$ 1.60$.

No. 22. Cut, 9,12 or 18 in. long, 25c. per lb.; per box, 12 lbs., $\$ 1.85$.

No. 24. Cut, 9, 12 or 18 in. long, 30c. per lb.; per box, 12 lbs., $\$ 2.40$.

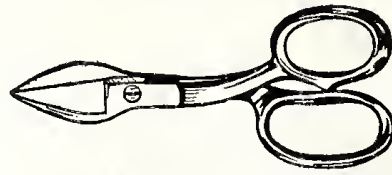

WIRE SNIPS

No. 369-71/2 inches, serrated edge, long blade ................ $\$ 1.50$

No. $833-7 \mathrm{i} / 2$ inches, short blade.... $\quad .90$

No. 832 - 8 inches, long blade..... 1.00

No. 12- 8 inches, heavy......... 1.10

No. $10-10$ inches, heavy.......... 1.60

\section{CARNATION SUPPORTS} 3-RIN G

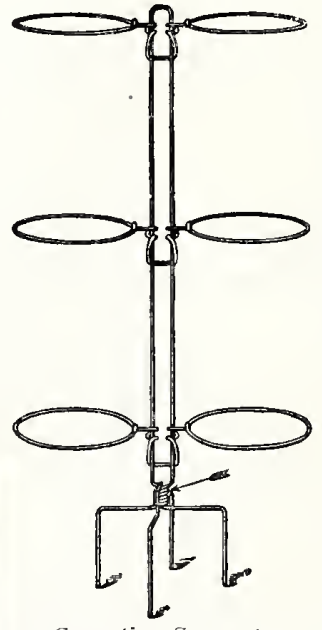

The best double support on the market; made of Nos. 11 and 14 galvanized wire 28 inches high; can be put together in less than a minute; will not fall apart. Per $100 \ldots \$ 11.50$ Per $1000 \ldots 100.00$

MICHELL'S DOUBLE SNAPDRAGON SUPPORTS

The only support of the kind on the market and indispensable to the proper growing of this popular plant. Per doz., $\$ 2.00 ; \$ 15.00$ per 100 . 
Parcel Post charges where named are for shipment up to and including third zone; for other zones, please add additional postage.

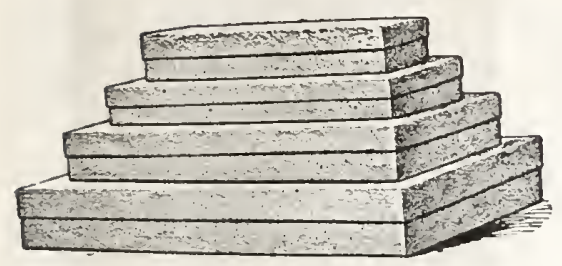

\section{CUT FLOWER BOXES CORRUGATED PAPER (For Shipping)}

Used almost exclusively for carrying and shipping cut flowers; they are lighter than wooden ones.

$48 \times 14 \times 8$ inch $\quad$ Each Doz. 100 $.50 \$ 4.75$

$42 \times 14 \times 8$ inch......
$36 \times 14 \times 6$ inch...
30

$\begin{array}{llll}30 \times 12 \times 6 \text { inch....... } & .35 & 3.50 & 22.00 \\ 24 \times 8 \times 5 \text { inch...... } & .30 & 3.00 & 15.00\end{array}$

\section{DOUBLE TELESCOPE BOX}

Made of $175 \mathrm{lb}$. test board, one size only, $48 \times 14 \times 8$; can be shipped by express without crating. 75 c. each; doz., $\$ 7.50 ; \$ 55.00$ per 100 .

\section{BOXES FOR STORE USE}

Mist green lined white inside. The sizes offered in this finish are carried in stock; other sizes in this finish also in manila, mist tan and oxford gray can be supplied on short notice. Boxes shipped from stock are supplied not printed only - we can furnish boxes printed, shipment from factory in about two weeks.

L. W. D.

$16 \times 4 \times 3$ inch.

* $18 \times 5 \times 3$ inch.

Price f.o. b. Price f. o. b.

$20 \times 4 \times 3$ inch. Phila.
Per Doz. Per 100 Pactory
Per 100

$21 \times 5 \times 3$ inch.

$21 \times 7 \times 31 / 2$ inch.

* $24 \times 5 \times 31 / 2$ inch.

* $24 \times 8 \times 4$ inch..

$24 \times 8 \times 5$ inch.

$28 \times 8 \times 4$ inch.

*28 x 8 x 5 inch.

$30 \times 5 \times 4$ inch.

* $30 \times 10 \times 6$ inch.

*30 × $12 \times 7$ inch.

$36 \times 6 \times 5$ inch

* $36 \times 8 \times 5$ inch.

$36 \times 10 \times 6$ inch.

$42 \times 8 \times 5$ inch.

$\begin{array}{rr}\$ 0.55 & \$ 4.00 \quad \begin{array}{r}2.80 \\ 3.20 \\ 3.20\end{array}\end{array}$

3.20
3.60

5.20

$\begin{array}{rrr}.85 & 6.25 & 5.00 \\ 1.10 & 8.00 & 6.40\end{array}$

6.40
7.20

7.20

$\begin{array}{lll}1.50 & 10.00 & 8.80 \\ & & 6.16\end{array}$

$\begin{array}{lll}1.90 & 14.00 & 11.76\end{array}$

$\begin{array}{lll}2.50 & 18.00 & 15.20\end{array}$

$\begin{array}{rrr}1.90 & 13.00 & 11.20\end{array}$

14.40

Sizes marked * are carried in stock at Philadelphia, the other sizes are shipped from the factory in New York state in lots of not less than 50 of a size.

VIOLET AND CORSAGE BOXES Pricef. o. b. Price f.o.b. $8 \times 5 \times 5$ inch $\quad \begin{array}{cr}\text { Per } 100 & \text { Per } 100 \\ \$ 4.20 & \$ 3.36\end{array}$ $9 \times 6 \times 5$ inch .......... $4.50 \quad 3.60$ $12 \times 6 \times 5$ inch.......... $5.50 \quad 4.40$ $12 \times 10 \times 6$ inch ...... $7.70 \quad 6.16$ $15 \times 6 \times 5$ inch ........6. 6.25

\section{DESIGN BOXES}

Manila lined board in heavy weights. Price f. o. b. Price f. o. b. Phila, Factory
Per 100 Per 100

$16 \times 16 \times 8$ inch

$\$ 14.00$

$18 \times 18 \times 8$ inch 3 -in...

15.40

$20 \times 20 \times 9$ inch

20.30

23.00

$\$ 11.20$

$\$ 12.32$

16.24

SPECIAL NOTE. - When it is desired to have boxes printed, please add $\$ 2.00$ to prices named, regardless of quantity.

\section{PARCEL POST CUT} FLOWER BOXES

For shipping cut flowers; made of fibre board; brown in color.

F. o. b. factory only.

$25 \times 5 \times 4$ inch

$24 \times 8 \times 5$ inch

$28 \times 8 \times 5$ inch 3 .

$30 \times 14 \times 8$ inch lid...

$36 \times 12 \times 7$ inch covers.

$13 \times 9 \times 6$ inch

$20 \times 20 \times 8$ inch

$24 \times 24 \times 10$ inch

\section{Moss}

We make a specialty of long, clean, selected sphagnum moss; florists will find the quality we furnish to be much better than the average.

Sphagnum, Live or Green. Peck, 40c.; $\$ 1.25$ per bushel; per bbl., $\$ 2.75$.

Sphagnum, Dry. Barrel sacks, $\$ 1.00$.

Sphagnum, Dry. Finest quality, Wis. moss in burlapped bales, $45 \times 16 \times 14$ inches, $\$ 1.50$ per bale; 5 bales, $\$ 7.00$; $\$ 12.50$ per 10 bales. Special prices quoted f. o. b. Wis. shipping point.

Green Lump. Peck, $45 \mathrm{c}$; $\$ 1.50$ per bushel; bbl. bag, $\$ 2.50$.

Green Sheet. Per $10 \mathrm{lb}$. bale, $\$ 2.00$.

\section{WIRED TOOTHPICKS}

Regular Size. Per 1,000, 40c. (by P. P. 50c.); $\$ 2.75$ per 10,000 (by P. P., $\$ 3.00$ ) $50,000, \$ 10.50$.

3 inch, dyed green, per box of $8,000, \$ 3.75$ (by P. P., $\$ 4.00) ; \$ 16.00$ per case of 40,000 .

4 inch, dyed green, per box of $4,500, \$ 3.25$ (by P. P., $\$ 3.50) ; \$ 6.50$ for 10,000 .

6 inch, dyed green, per box of $3,000, \$ 3.00$ (by P. P., $\$ 3.25$ ); $\$ 8.50$ for 10,000 .

WIRED TOOTHPICK HOLDER

A handy device for holding wired toothpicks. Price, $\$ 2.25$ (by P. P., \$2.40).

\section{TINFOIL}

If wanted by parcel post, please add for postage as follows: 10c. for 1 lb.; 20c. for 5 lbs.; 30c. for 10 lbs.

Plain (5 lb. rolls).5 in.

Plain (5 lb. rolls).5 in. $\$ 1.00$

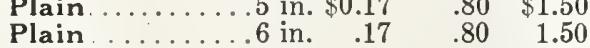

Violet Foil ....6 in. $\quad .30 \quad 1.45$

Green Foil .....6 in. $\quad .30 \quad 1.45$

\section{ALUMINUM FOIL}

Green or lavender, width, 5 inches; 48 yds. to roll. Per roll, $\$ 1.75 ; 10$ roll lots, $\$ 1.70$ per roll.

Ask for prices on large quantities of foil.

Tinfoil Holder and Cutter for rolls of Tinfoil, 85c. (by P. P., $\$ 1.00$ ).

\section{GREENING OR FLORISTS' HAIR PINS}

Save valuable time in making designs. Price, $\$ 2.00$ per 10 lb. box (by P. P., $\$ 2.30$ ).

CARNATION MENDING DEVICES

Staples. For calyx mending, 30c. per 1,$000 ; 5,000$ for $\$ 1.45 ; \$ 2.70$ for 10,000 ; 25,000 for $\$ 6.50 ; \$ 12.50$ for 50,000 .

Rubber Bands. Ounce, 25c.; 85c. per $1 / 4$ lb.; $1 / 2$ lb., $\$ 1.60 ; \$ 3.00$ per lb.

\section{Bauer Carnation outfits}

Pliers and 1,000 clips, $\$ 3.50$.

Pliers, each, $\$ 2.50$.

Clips. $\$ 1.00$ per 1,000 .

\section{PAPER FOR WRAPPING BOXES AND FLOWERS}

Lb. 1/2 Ream Ream

$\begin{array}{lrrr}\text { Manila. For wrapping. } \$ 0.14 & \$ 2.00 & \$ 3.50 \\ \text { Manila. Tissue. . . } & .20 & .90 & 1.60\end{array}$

White Wax. Best qual-

ity, $24 \times 36$ inches. .

Green Wax. Best qual-

ity, $24 \times 36$ inches ... $.35 \quad 1.50 \quad 2.75$

$\begin{array}{lll}.30 & 1.40 & 2.60\end{array}$

Green Wax. In 3 in. wide rolls, for wrapping frames of designs. 25c. per roll; doz., $\$ 2.50$.

\section{FLORISTS' SUNDRIES}

Bulb Fibre. Per qt., 10c.; 35c. per 1/2 pk.; pk., 60c.; $\$ 1.00$ per $1 / 2$ bu.; bu., $\$ 1.50$.

Bull Dog Clips. For fastening packages, boxes, etc.; 90c. per box of 1,000.

Carnation Dye. All colors. Per pkg., 50c.

Celery Paper. In 500 square foot rolls, $\$ 1.35$ per roll.

Celery Tape (Red), 1,000 yard spool, $\$ 3.50$ (by parcel post, $\$ 3.65$ ).

Celery Tape (Green). 1,000 yard spool, $\$ 3.00$ (by parcel post, $\$ 3.15$ )

Charcoal (Lump). Peck, 40c.; $\$ 1.00$ per bu.; bbl. sack, $\$ 1.50$.

Charcoal (Ground). Coarse or fine. Per 5 lbs., 30c.; $\$ 1.00$ per 25 lbs.; 100 lbs., $\$ 3.50$.

Leaf Mould. Per peck, $40 \mathrm{c}$; $\$ 1.25$ per bu.; bbl., $\$ 2.75$.

Pearl Chips. For bulb bowls, aquariums, etc., white and assorted colors. 15c. per pkg.; 6 pkgs., for $80 \mathrm{c}$; $\$ 1.50$ per 12 pkgs.; 25 pkgs. for $\$ 3.00 ; \$ 11.00$ per 100 .

In bulk, 5 lbs., 65 c.; $\$ 1.25$ per 10 lbs.; 25 lbs., $\$ 2.75 ; \$ 5.00$ per 50 lbs.; 100 lbs., $\$ 9.00$.

Peat. Per peck, 40c.; $\$ 1.25$ per bu.; bbl., $\$ 2.75$.

Peat, Orchid. Per peck, 60c.; $\$ 1.50$ per bu.; bbl. sack, $\$ 3.00$.

Peat Moss (Turf Mull). Imported, Granulated. A great soil improver; used extensively by leading florists, for mixing with potting soil, for propagating benches, also for packing bulbs and plants; useful for mulching in the flower and vegetable garden. Large bale,

$\$ 3.00 ; \$ 27.50$ per 10 bales.

Pebbles. Per qt., 8c.; 55c. per peck; bu., $\$ 2.00 ; \$ 4.00$ per sack.

Pruning Compound or Tree Paint. Per qt., 45c.; $\$ 1.40$ per gal.

Sand. For propagating. Per peck, 35c.; $\$ 1.25$ per bu.; bbl. sack, $\$ 2.75$.

Shaderine. 5 lbs., $\$ 1.00 ; \$ 2.00$ per 10 lbs.

Tree Paint. Per qt., 75c.; $\$ 2.25$ per gal.

Weed Killer (Michell's). Dilutes 1 gallon to 40 gallons of water. Per qt., $50 \mathrm{c}$. $; \$ 1.50$ per gal.; 5 gals., $\$ 6.00 ; \$ 11.00$ per 10 gals.; 30 gals., $\$ 27.00 ; \$ 42.50$ per 50 gals.

Weed Killer Duster (Non-poisonous). Kills poison ivy, quack grass, thistle and all other forms of vegetation. $1 \mathrm{lb}$. Duster (kills 100 sq. ft. of weeds), 50c.; $31 / 2 \mathrm{lb}$. Duster (kills 350 sq. ft. of weeds), $\$ 1.50$; 50-lb. drum, $\$ 10.00$

Zementine. For whitewashing and shading glass. Per 2 lbs., $35 \mathrm{c}$.; $\$ 1.65$ per $10 \mathrm{lbs}$. 


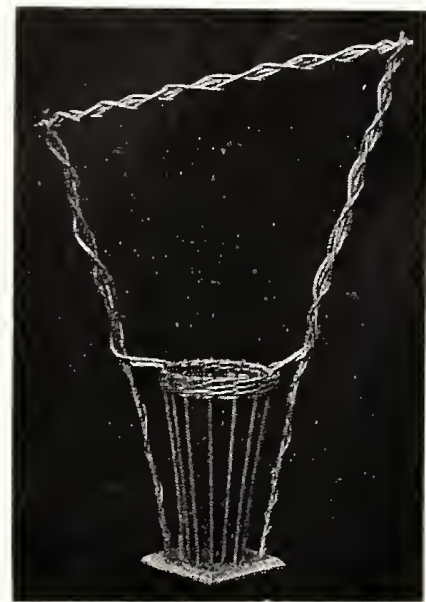

901

FLOWER BASKET

No. 901. 30 in. high; 12 in. deep; 7 in. diam. 90c. each; doz., $\$ 10.00$.

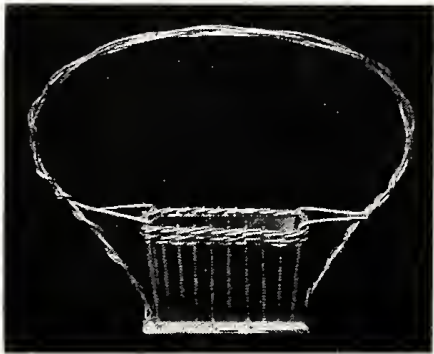

1

FLOWER BASKET

No. 1. $18 \frac{1}{2}$ in. high; 10 in. long; 5 in. wide; 7 in. deep. 75c. each; doz., $\$ 8.75$.

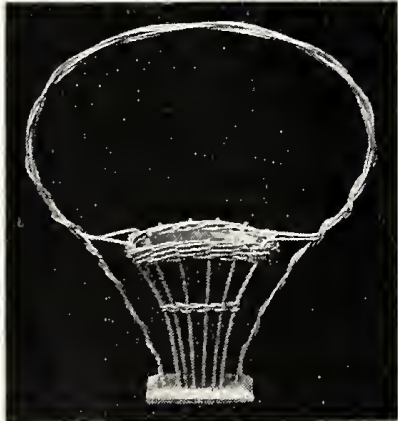

3

FLOWER BASKET

No. 3. $231 / 2$ in. high; $91 / 2$ in. long; 5 in $10 \frac{1}{2}$ in. deep. 70 c. each; doz., $\$ 8.25$.

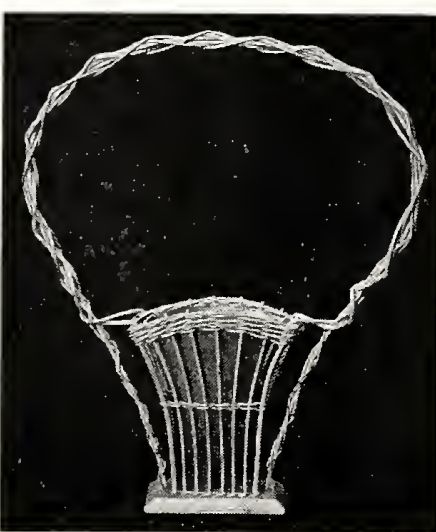

184

FLOWER BASKET

No. 184. 29 in. high; 11 in. long; 4 in. wide; $12 \frac{1}{2}$ in. deep. $\$ 1.25$ each; doz., $\$ 14.50$.

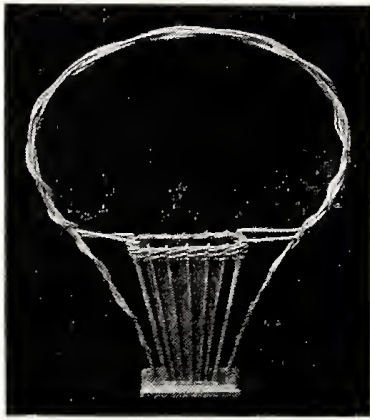

2

FLOWER BASKET

No. 2. 23 in. high; 7 in. long; 3 in. wide; $91 / 2$ in. deep. 60c. each; doz., $\$ 7.00$.

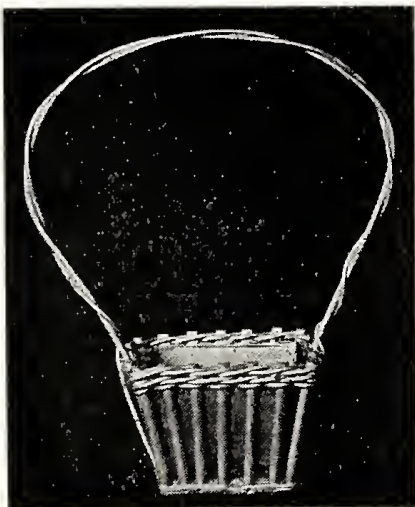

26

FLO WER BASKET

No. 26. $17 \frac{1}{2}$ in. high; 8 in. long; 6 in. wide; $51 / 2$ in. deep. 55c. each; doz., $\$ 6.50$.

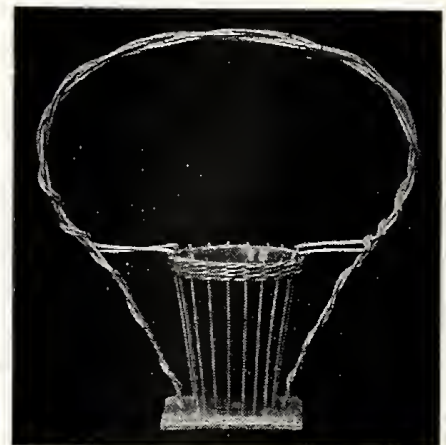

$101 / 2$

FLOWER BASKETS

No. 101/1. 19 in. high; $71 / 2$ in. long; 6 in. wide; 8 in. deep. 65c. each; doz., $\$ 7.50$. No. $101 / 2.24$ in. high; $81 / 2$ in. long; $61 / 2$ in. wide; $101 / 2$ in. deep. 80c. each; doz., $\$ 9.25$. No. 101/3. 28 in. high: 11 in. long; 8 in. wide; 12 in. deep. $\$ 1.35$ each; doz., $\$ 16.00$.

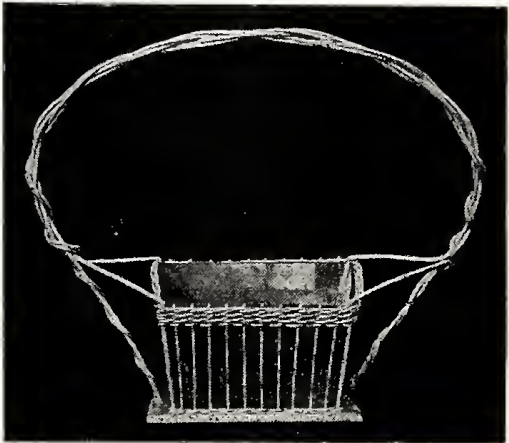

565

FLOWER BASKET

No. 565.24 in. high; 13 in. long; 6 in. wide; 7 in. deep. $\$ 1.20$ each; doz., $\$ 14.25$.

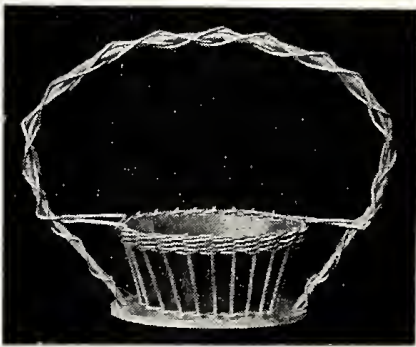

$876 / 1$

FLOWER BASKET

No. 876/1. 17 in. high; 12 in. long; $81 / 2$ in. wide; 6 in. deep. $\$ 1.00$ each; doz., $\$ 11.50$.

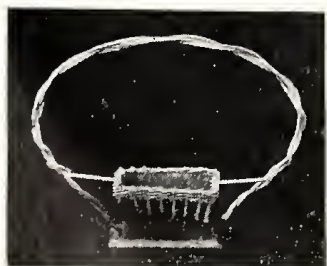

$442 / 0$

\section{FLOWER BASKET}

No. $442 / 0.13$ in. high; $61 / 2$ in. long; $41 / 2$ in. wide; 4 in. deep. $45 \mathrm{c}$. each; doz., $\$ 5.25$.

Our baskets are fitted with water tight tin liners.

\section{FLOWER BASKETS}

No. $P / 6.11$ in. high; 21 in. long, overall; 6 in. wide; $41 / 2$ in. deep. 60c. each; doz., $\$ 7.00$.

No. $\mathbf{P} / 10.11$ in. high; 27 in. long, overall; 8 in. wide; $51 / 2$ in. deep. $\$ 1.00$ each; doz., $\$ 11.50$.

No. $\mathbf{P} / 12$. 15 in. high; 30 in. long, overall; 8 in. wide; 6 in. deep. $\$ 1.15$ each; doz., $\$ 13.25$.

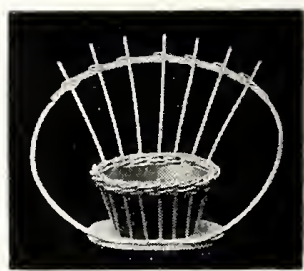

$\mathrm{P} / 6$ 


\section{MICHELL'S FLOWER BASKETS GOLD STAR}

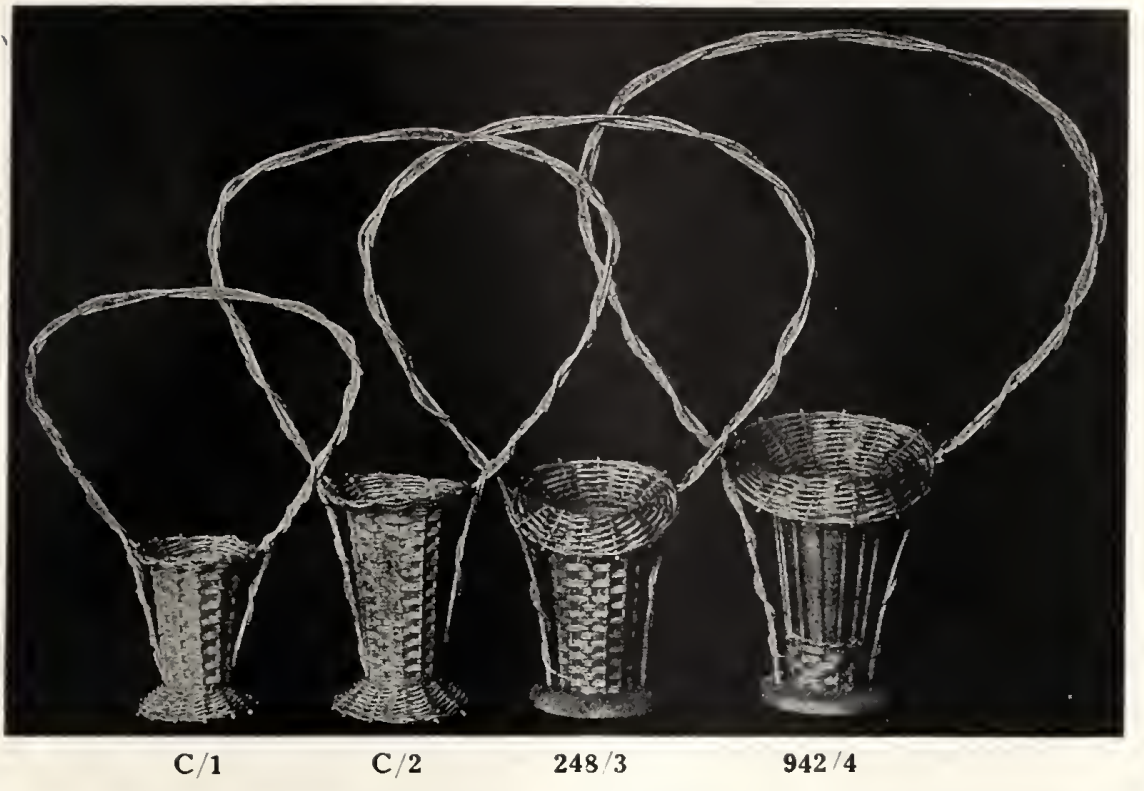

FLOWER BASKETS

No. C/1, $181 / 2$ in. No. C/2. $251 / 2$ in. $5 \frac{1}{2}$ in. diam., $50 \mathrm{c} . \quad 6 \frac{1}{2}$ in. diam., $65 \mathrm{c}$. each; doz., $\$ 5.75$. each; doz., $\$ 7.50$.

See page 49 for Special Assortments of Baskets.

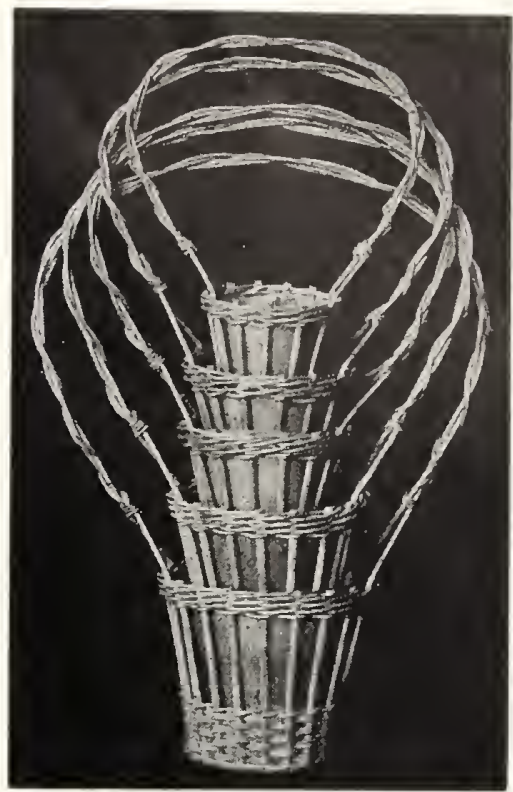

$908 / 4$

\section{F LANT BASKETS}

high; 10 in. deep; high; 11 in. deep $71 / 2$ in. diam., 80c. $91 \frac{1}{2}$ in.diam., $\$ 1.05$ each; doz., $\$ 9.25$.

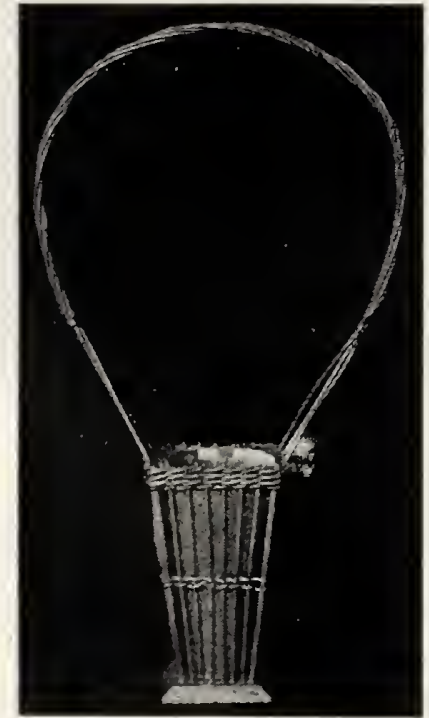

$886 / 12$

\section{FLOWER BASKETS}

No. 886/1. 20 in. high; 7 in. deep; $4 \frac{1}{2}$ in. diam. 45 c. each; doz., $\$ 5.25$. No. 886/6. $241 / 2$ in. high; 9 in. deep; $51 / 2$ in. diam. 55c. each; doz., $\$ 6.50$. No. 886/12. 30 in. high; 11 in. deep; 7 in. diam. $\$ 1.10$ each; doz., $\$ 12.50$. No. $886 / 14,36$ in. high; 13 in. deep; 8 in. diam. $\$ 1.25$ earh: doz., $\$ 14.00$.

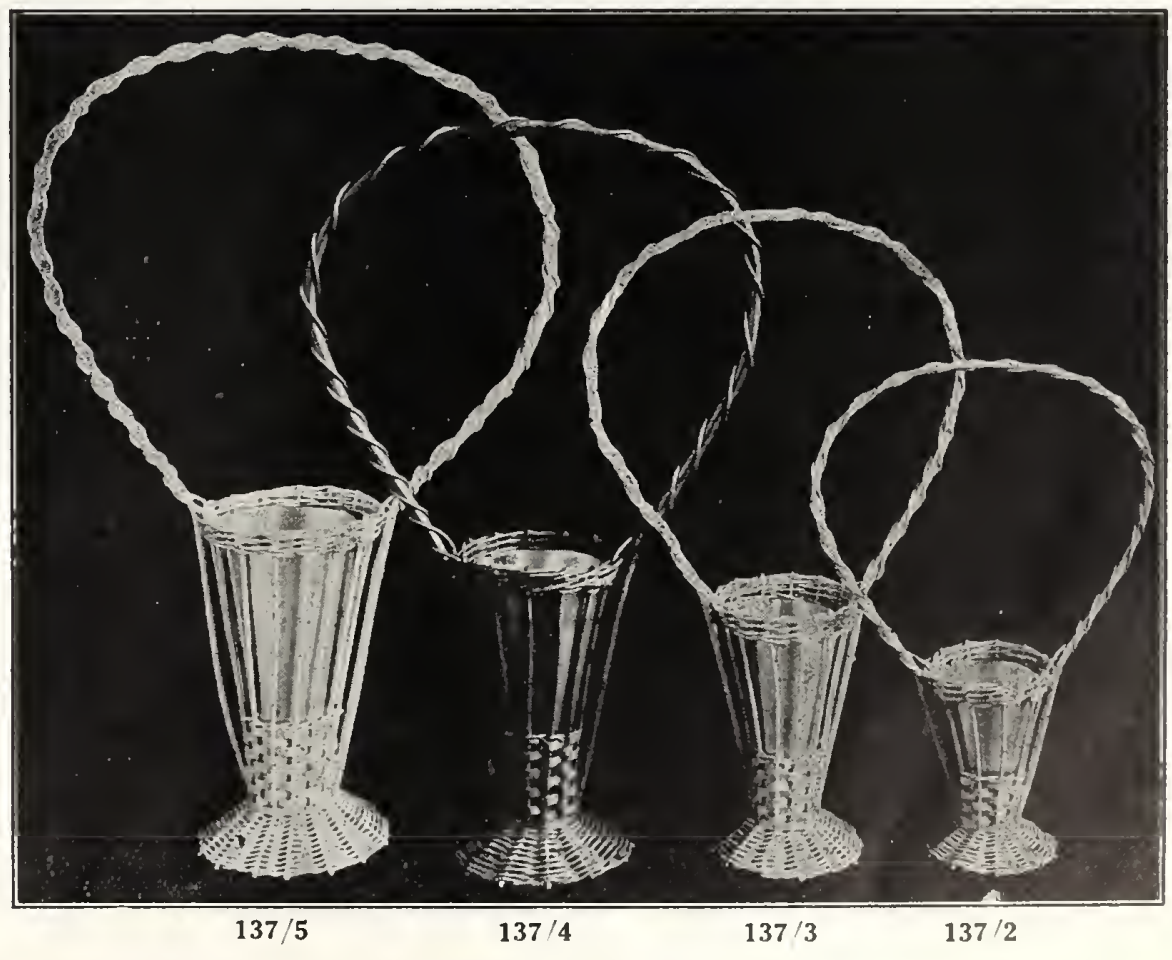

FLOWER BASKETS

No. 137 5. 34 in. No. 137/4. 30 in. No. 137/3. 27 in. No. 137'2. 24 in. high; 15 in. deep; high; 13 in. deep; 7 in. diam., $\$ 1.25 \quad 61 / 2$ in.diam., $\$ 1.00$ each; doz.. $\$ 14.00$. each; doz., $\$ 11.00$. high;101\%in.deep; each; doz., $\$ 10.00$. 5 in. diam., $85 \mathrm{c}$. high: 81 in deep: 4 in. diam., $60 \mathrm{c}$ each; doz., $\$ 7.00$.
No. 908/4. $17 \mathrm{in.} \mathrm{high;} 51 / 2$ in. deep; 7 in. diam. 60c. each; doz., $\$ 7.00$.

No. 908/5. 20 in. high; $61 / 2$ in. deep; $81 / 2$ in. diam. 80c. each; doz., $\$ 9.25$.

No. 908/6. $21 \frac{1}{2}$ in. high; 7 in. deep; $81 / 2$ in. diam. 90c. each; doz., $\$ 10.25$.

No. 908/7. 25 in. high; 8 in. deep; 10 in. diam. $\$ 1.00$ each; doz., $\$ 11.50$. 


\section{MICHELL'S FLOWER BASKETS GOLD STAR}

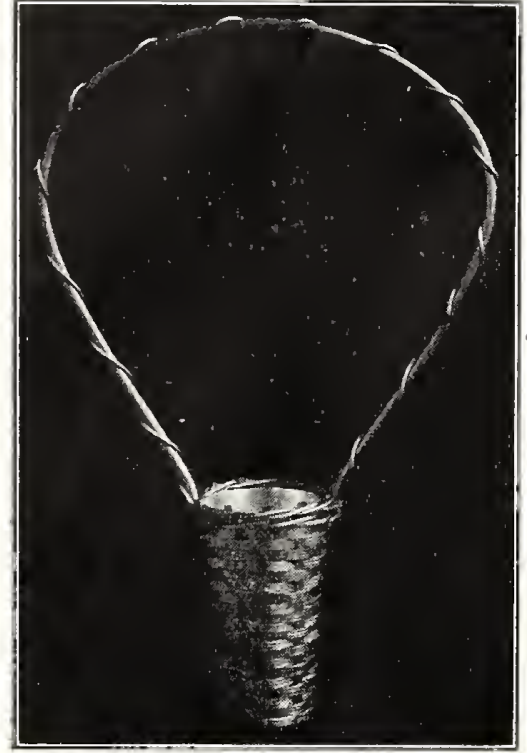

23

FLOWER BASKET

No. 23. 24 in. high; 8 in. deep; 5 in. diam. 45c. each; per 100, $\$ 40.00$.

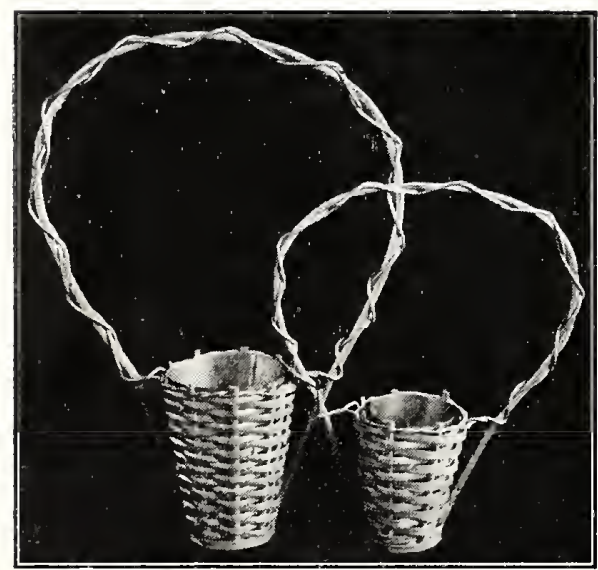

$151 / 3$

$151 / 1$

FLOWER BASKETS

No. 151/3. $191 / 2$ in. high; 7 in. deep; 5 in. diam. 50c. each; per $100, \$ 45.00$.

No. 151/1. 14 in. high; $51 / 2$ in. deep; $31 / 2$ in. diam. 40c. each; per 100, $\$ 35.00$.

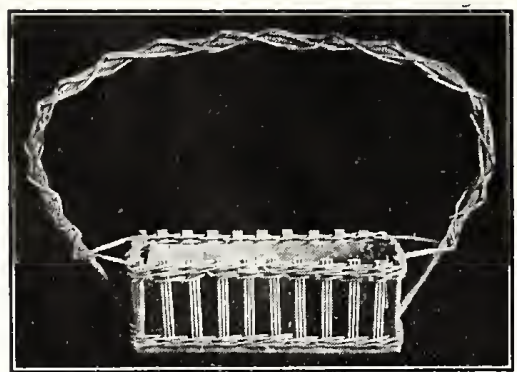

$245 / 15$

FLOWER AND PILLOW BASKET

No. 245/15. 18 in. high; $151 / 2$ in. long; 6 in. wide; $51 / 2$ in. deep. $\$ 1.65$ each; doz., $\$ 18.50$.

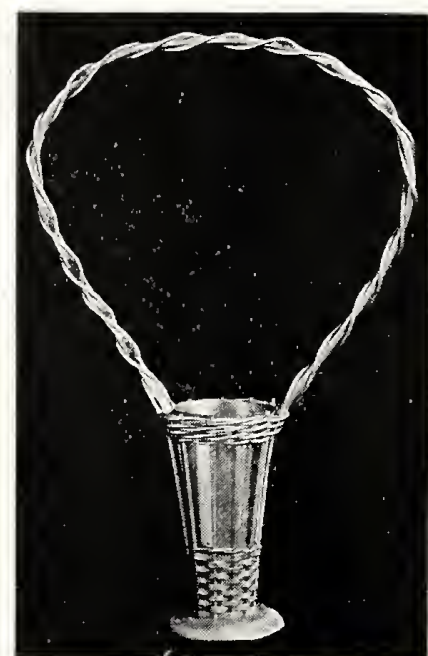

R 133/4

FLOWER BASKETS

No. 133/4. 30 in. high; 11 in. deep; $4 \frac{1}{4}$ in. diam. 95c. each; doz., $\$ 11.00$.

No. 133/5. 32 in. high; 13 in. deep; 7 in. diam. $\$ 1.10$ each; doz., $\$ 12.00$.

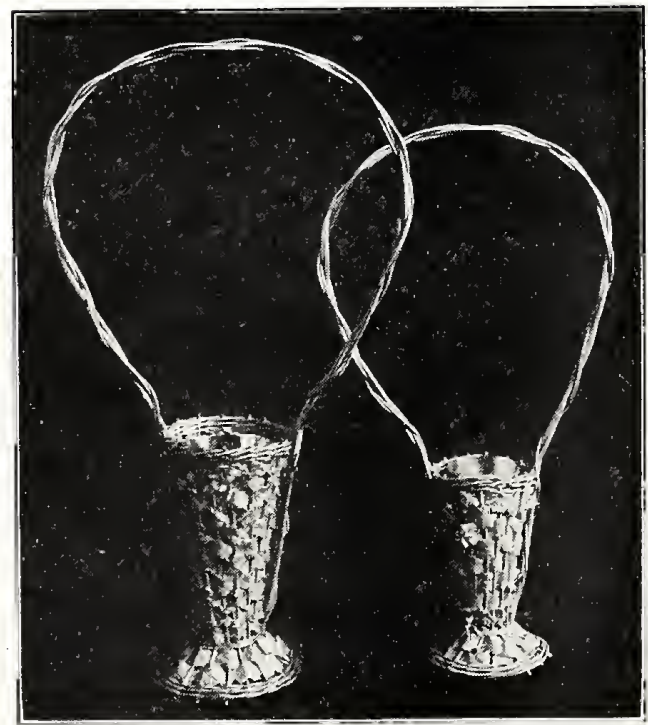

$900 / 5$

$900 / 4$

FLOWER BASKETS

No. 900/5. 38 in. high; 13 in. deep; 8 in. diam. $\$ 1.10$ ?each; doz., $\$ 12.50$.

No. 900/4. 33 in. high; 10 in. deep; $6 \frac{1}{2}$ in. diam. 85c. each; doz., $\$ 10.00$.

\section{FLOWER AND PILLOW BASKET}

No. 246/15. 17 in. high; $121 / 2$ in. long; $61 / 2$ in.wide; 5 in. deep. $\$ 1.35$ each; doz., $\$ 15.50$.

Our baskets are fitted with watertight tin liners, painted in colors to harmonize with the basket itself.

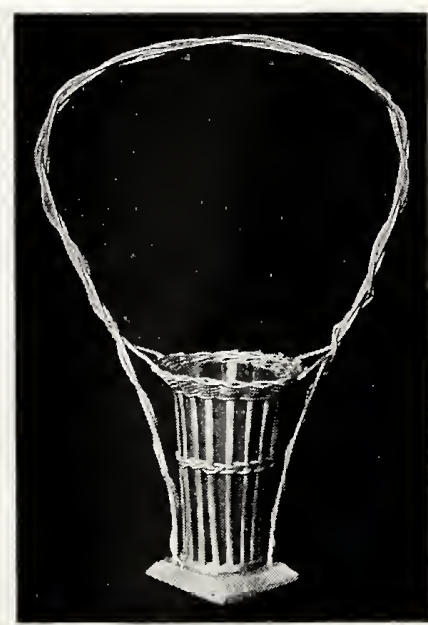

$071 / 3$

\section{FLOWER BASKETS}

No. 071/3. 30 in. high; 12 in. deep; $81 / 2$ in. diam. 85c. each; doz., $\$ 10.00$.

No. 071/4. 34 in. high; 14 in. deep; 9 in. diam. $\$ 1.25$ each; doz., $\$ 14.00$.

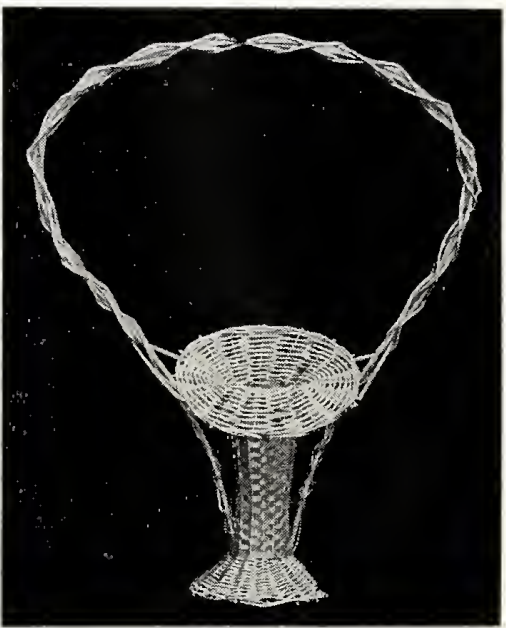

$850 / 4$

\section{FLOWER BASKETS}

No. 850/4. 32 in. high; 10 in. deep; 6 in. diam. $\$ 1.50$ each; doz., $\$ 17.00$. No. 850/6. 34 in. high; 15 in. deep; 6 in. diam. $\$ 2.25$ each; doz., $\$ 25.50$.

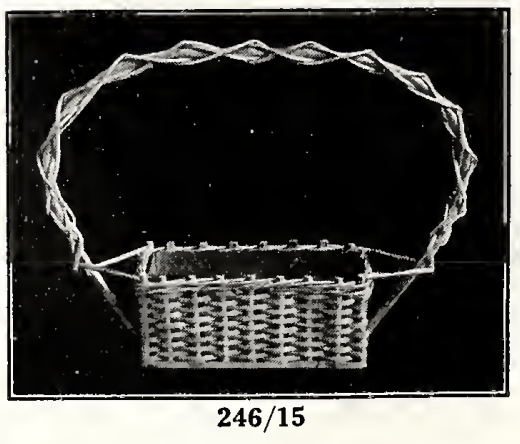




\section{MICHELL'S FLOWER BASKETS GOLD STAR}

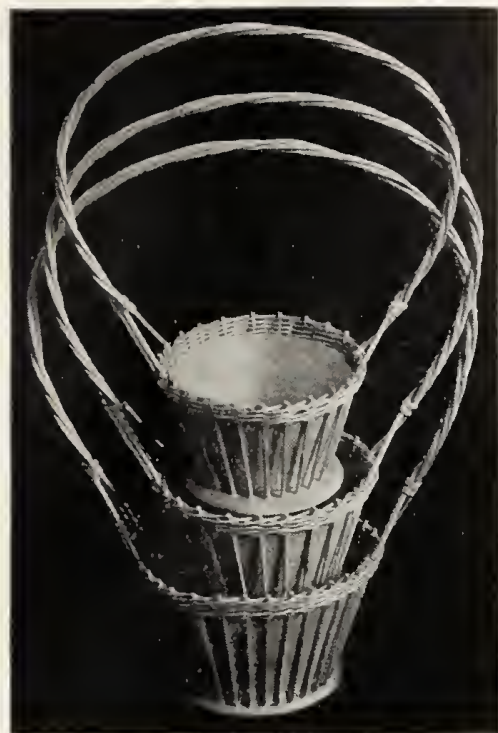

$996 / 6$

BULB PAN BASKETS

No. $996 / 6.20$ in. high; $51 / 2$ in. deep in. diam. 80c. each; doz., $\$ 9.50$.

No. 996/7. $21 \frac{1}{2}$ in. high; 6 in. deep; 10 No. 993/7. 27 in. high; 6 in. deep; 10 in. in. diam. \$1.00 each; doz., \$11.25.

No. 996/8. $231 / 2$ in. high; 6 in. deep; $11 \frac{1}{2}$ No. 993/8. 28 in. high; 7 in. deep; 11 in. in. diam. $\$ 1.25$ each; doz., $\$ 14.00$.

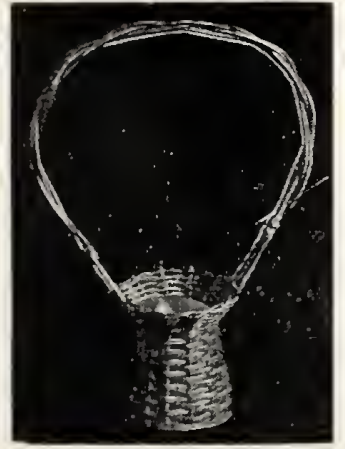

$158 / 1$

FLOWER BASKET

No. 158/1. 21 in. high; 6 in. deep; 6 in. diam. 60c. each; doz., $\$ 7.00$

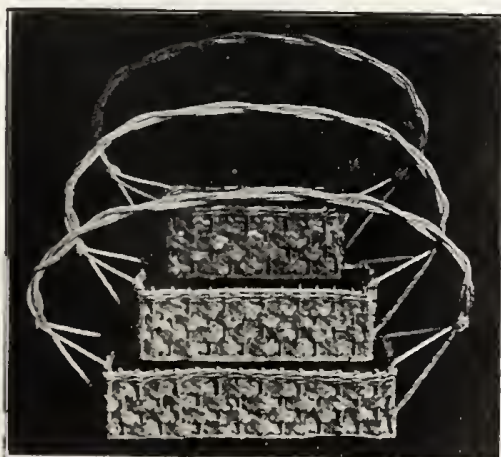

$742 / 1$

PILLOW BASKETS

No. 742/1. 18 in. high; 14 in. long; 5 in. wide; 5 in. deep. $\$ 1.10$ each; doz., $\$ 12.00$

No. 742/2. 18 in. high; 18 in. long; 6 in. wide; 5 in. deep. $\$ 1.25$ each; doz., $\$ 14.50$. No. 742 3. 18 in. high; 21 in. long; 6 in wide; 5 in. deep. $\$ 1.50$ each; doz., $\$ 17.00$.

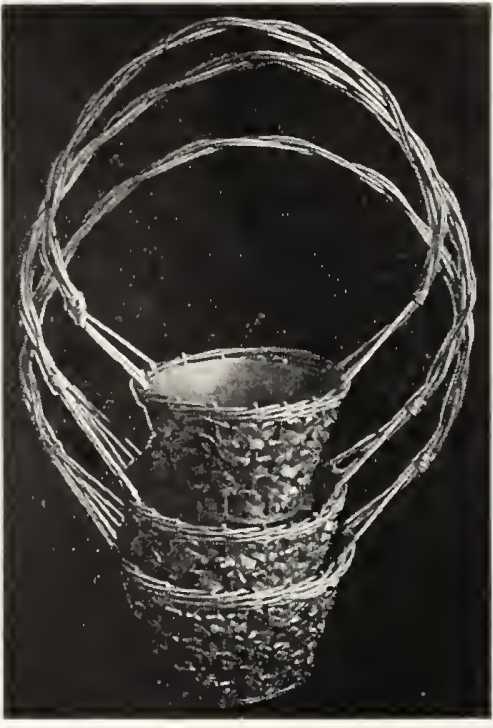

993

BULB PAN BASKETS

o. 993/6. 22 in. high; 6 in. deep; 8 in. diam. $\$ 1.05$ each; doz., $\$ 12.00$. diam. \$1.35 each; doz., \$15.75.

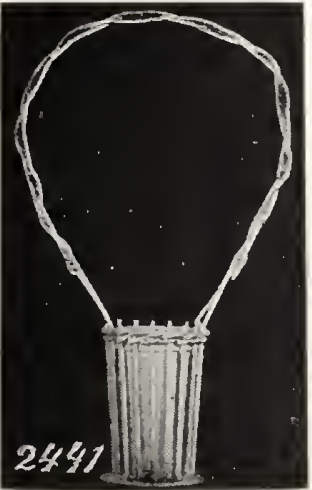

FLOWER BASKET

No. 2441. 20 in. high; 6 in. deep; $31 / 2$ in. diam. 0 c. each; per $100, \$ 35.00$.

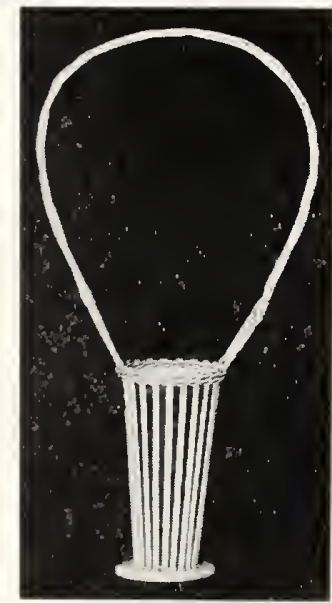

$129 / 3$

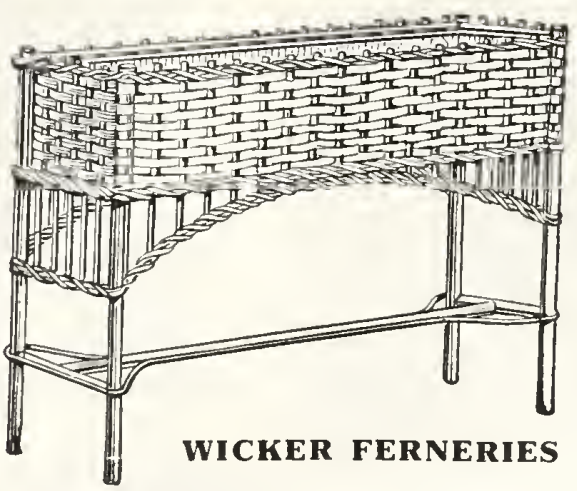

Finished in two-tone, with metal liners complete.

No. 24. Top dimensions, $8 \times 24$ inches, 30 inches high. Price, $\$ 4.00$.

No. 30. Top dimensions, $8 \times 30$ inches, 30 inches high. Price, $\$ 5.00$.

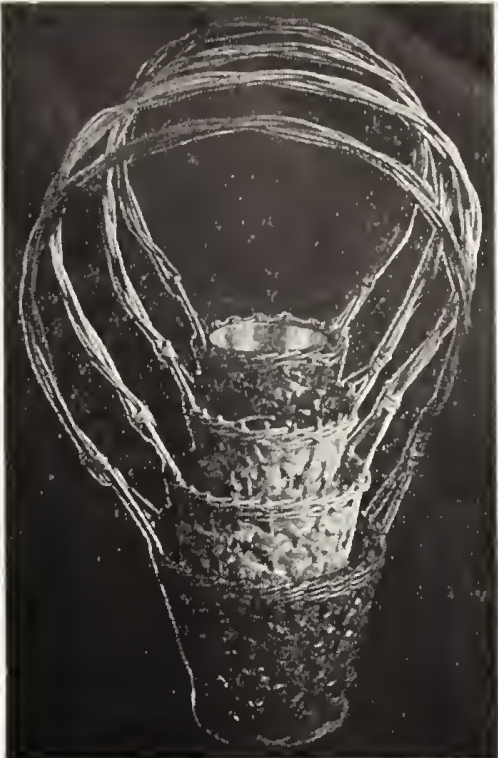

906

\section{PLANT BASKETS}

No. 906/4. 20 in. high; 6 in. deep; 6 in. diam. 60c. each; doz., $\$ 7.00$.

No. 906/5. 23 in. high; 6 in. deep; 7 in. diam. 75c. each; doz., $\$ 8.50$.

No. 906/6. 26 in. high; 7 in. deep; 8 in. diam. 85c. each; doz., $\$ 10.00$

No. 906/7. 29 in. high; 8 in. deep; $10 \mathrm{in.}$ diam. $\$ 1.05$ each; doz., $\$ 12.00$.

\section{FLOWER BASKETS}

No. 129/3. 26 in. high; 9 in. deep; 6 in. diam. 65c. each; per 100, $\$ 60.00$.

No. 129/4. 28 in. high, $101 / 2$ in. deep, 7 in. diam. 75c. each; doz., $\$ 8.50$

No. 129/5. $31 \frac{1}{2}$ in. high, 12 in. deep, 7 in diam. 95c. each; doz., $\$ 11.00$.

No. 1296.35 in. high, 14 in. deep, 7 in diam. $\$ 1.05$ each; doz., $\$ 12.00$.

\section{SPECIAL}

DE LUXE ASSORTMENT No. 1

This collection is just the thing for the busy florist; the assortment is composed of cut flower and plant baskets, all of our selected "Gold Star" brand, every one a work of art. 25 baskets, assorted colors, some plain and some two-tone. Each basket complete with liner. Price, $\$ 20.00$

\section{SPECIAL}

LUDLOW ASSORTMENT No. 2

Here is a collection of our "Gold Star" brand baskets that will please the florist who wishes a small collection that will meet every need.

There are 15 baskets in this lot, every one with a liner that won't leak; a beautiful range of colors; you will make no mistake ordering this lot. Price, $\$ 12.00$.

\section{SPECIAL}

GOLD STAR ASSORTMENT No. 3

There are 20 baskets in this assortment, which will meet the requirements of the most critical florist. An excellent combination of Plant and Cut Flower Baskets.

Each basket is complete with liner and the assortment of colors is the most that could be desired. There will be a basket in this assortment to meet every demand that the florist might have. Price, $\$ 15.00$.

The baskets which we offer are carefully selected and of the best quality. 


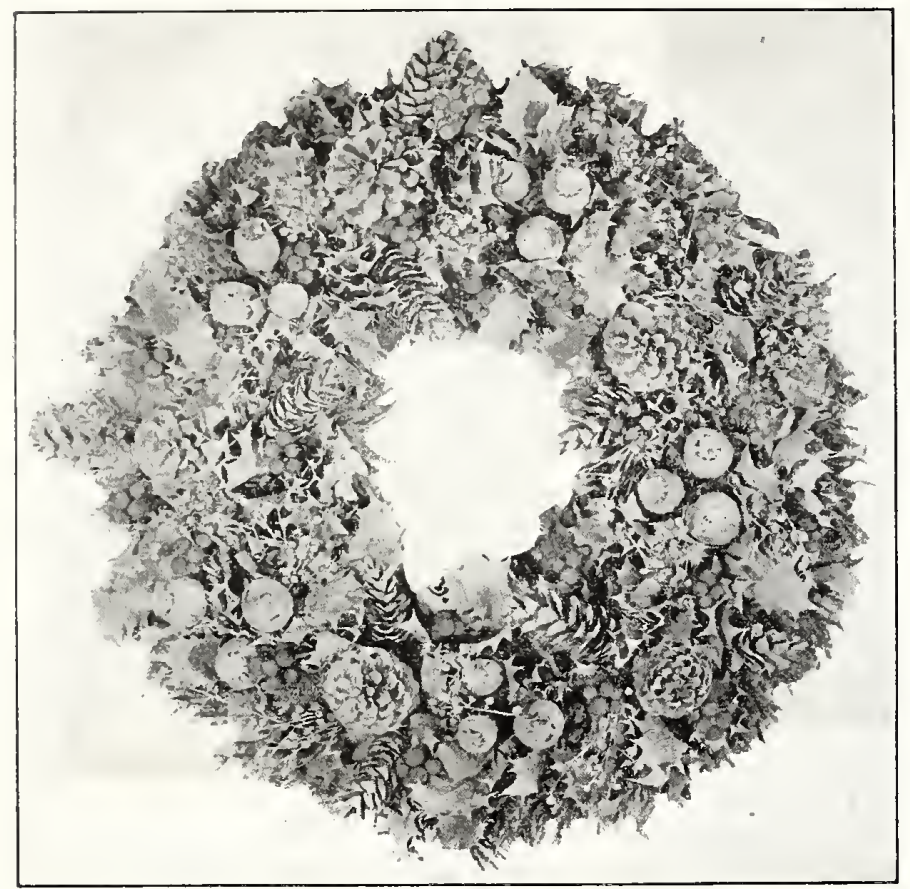

No. $300 / 1$

No. 300/1. Green and white frosted ruscus and lyco wreath with large cluster of silvered cycas leaves, green cones, red ruscus and other grasses. Through the body of the wreath are spread natural brown cones and red florabutts. 16-inch frame; 24 inches over all. $\$ 3.50$ each.

All Natural Prepared Wreaths are packed in individual boxes.

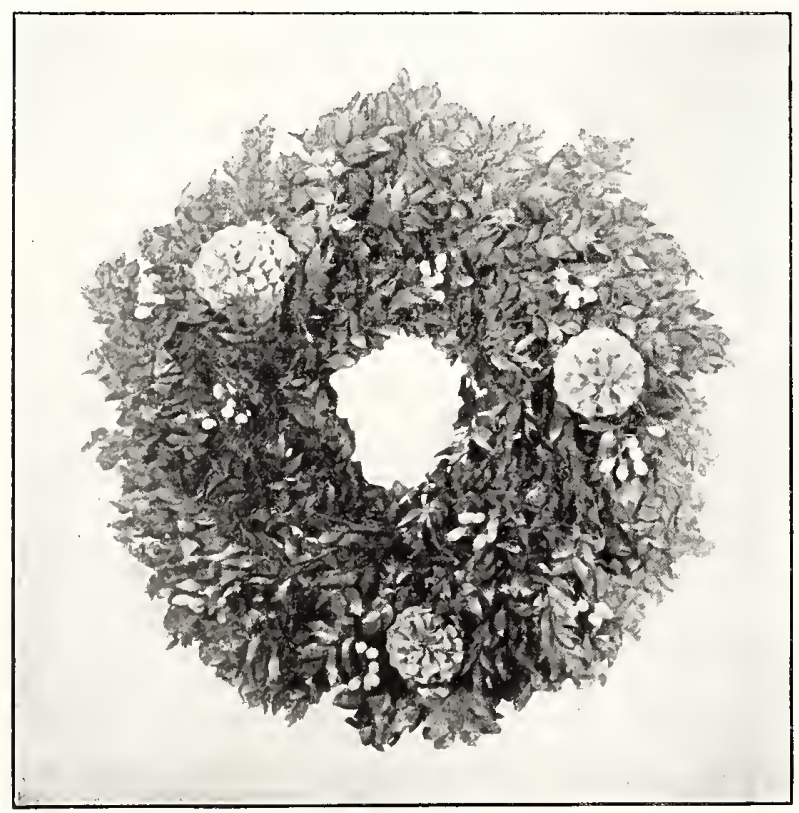

No. $340 / 3$

No. 340/3. Solid green ruscus wreath, with natural cone and red florabutt trimming. 16-inch frame; 22 inches over all. $\$ 2.50$ each.

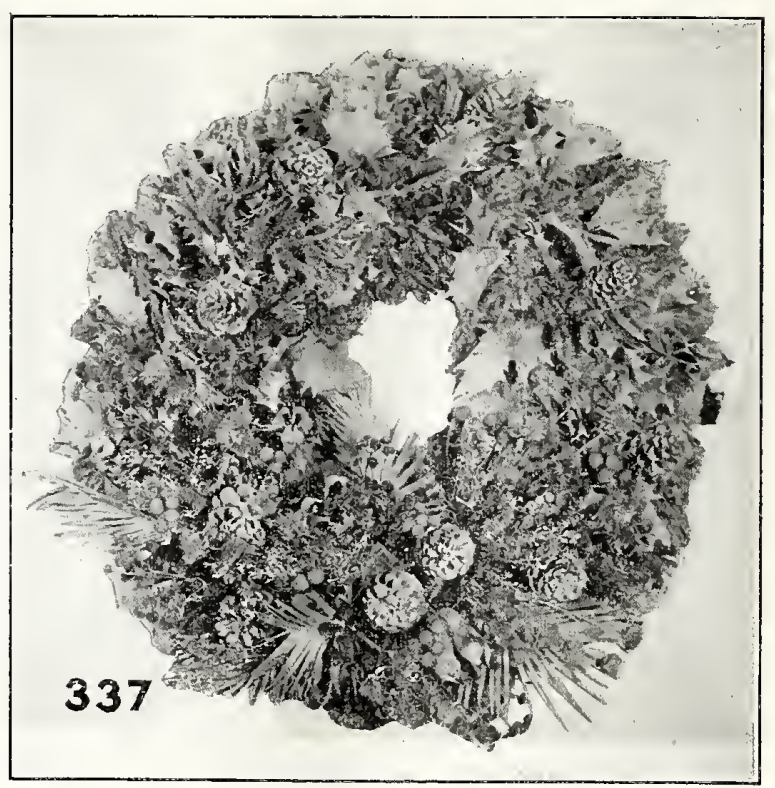

No. $240 / 3$

No. 240/3. Large cluster wreath, featuring natural prepared holly in a frosted green effect, with clusters of red florabutts throughout. 14-inch frame; 22 inches over all. $\$ 3.00$ each.

No. 210/1. Solid wreath of long cones, edged with ruscus in green frosted coloring, liberally trimmed with red florabutt clusters. A very natural looking wreath. 14-inch frame; 20 inches overall. $\$ 2.50$ each.

Our Wreaths have proven wonderful business builders for the retail florists' trade.

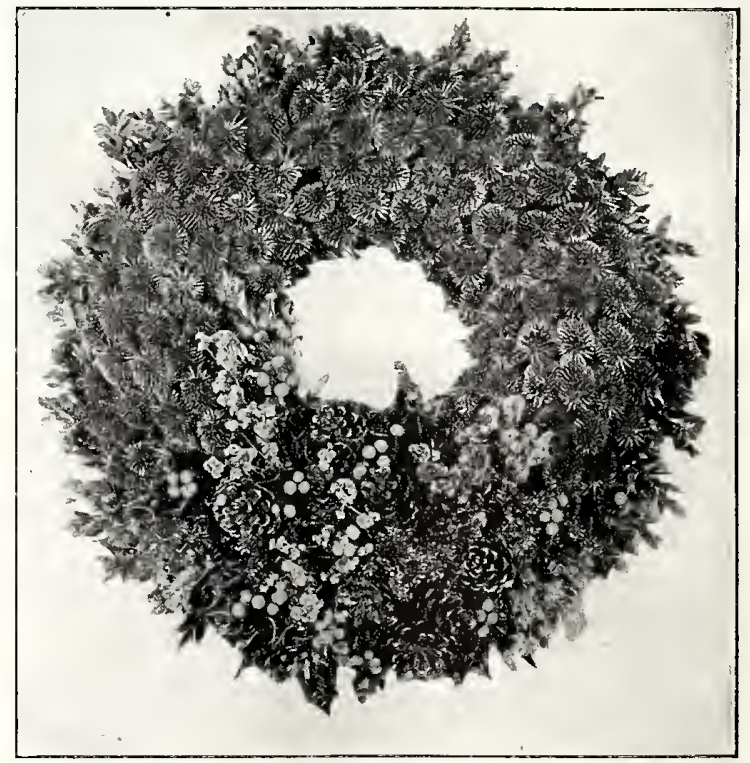

No. $480 / 2$

No. 480/2. Solid thistle wreath, edged with ruscus, in a lavender silvered finish. Big clusters of assorted grasses, holly sprays and cones. 16-inch frame; 24 inches overall. $\$ 6.50$ each.

No. 480/1. The same wreath in a red gold finish, with appropriate Christmas cluster. $\$ 6.50$ each. 


\section{MICHELL'S NATURAL PREPARED WREATHS}

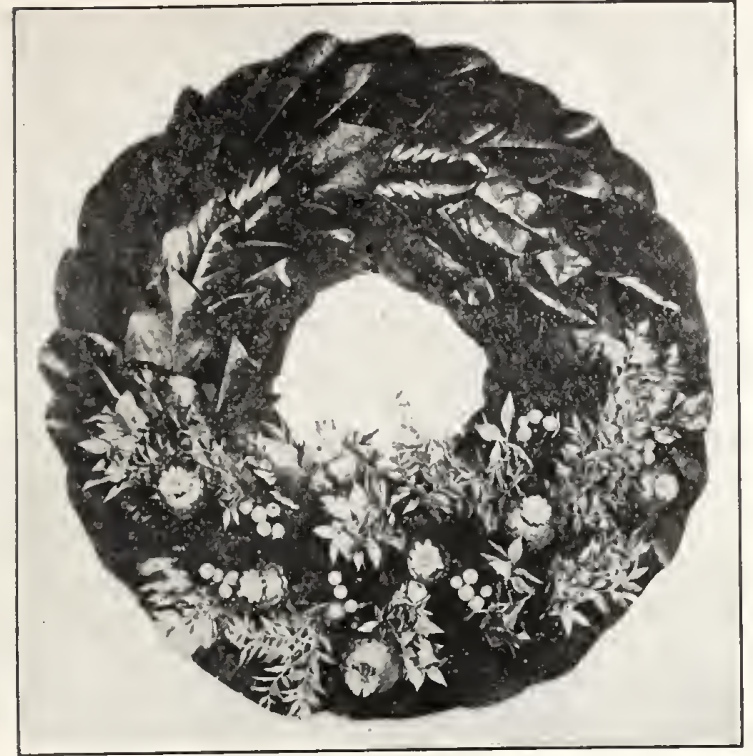

No. $106 / 3$

Brown magnolia wreath with clusters of red poinsettias, silver and green grasses and red holly berries.

No. 105/1. Size overall, 14 inches ............. \$ $\$ 0.80$

No. 106/1. Size overall, 16 inches.............. 1.00

No. 106/2. Size overall, 18 inches............... 1.50

No. 106/3. Size overall, 20 inches .............. 2.00

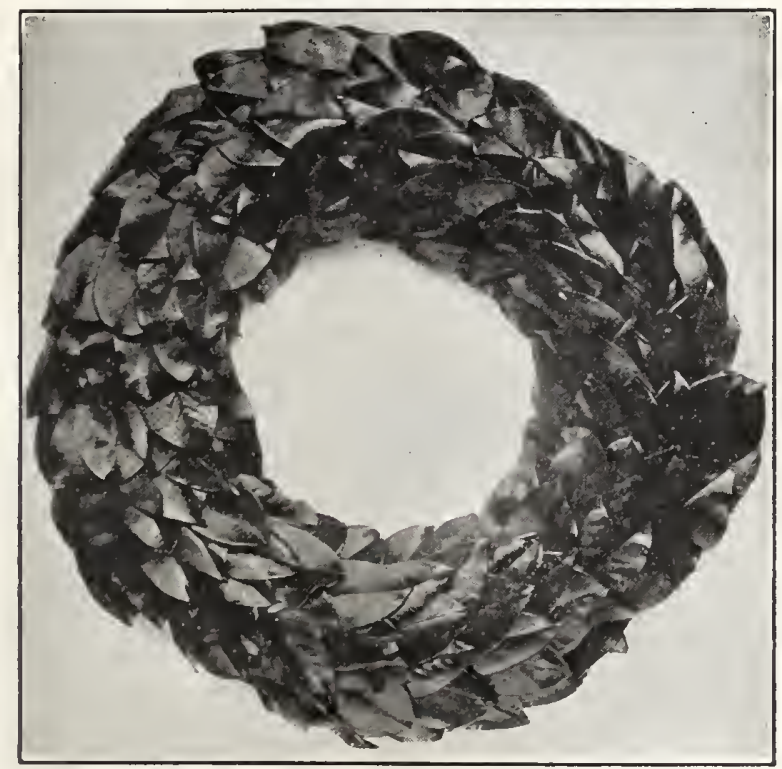

Magnolia Wreaths

\section{PLAIN ROUND MAGNOLIA WREATHS}

12 in. Frame

Made on Mossed Wire

14 in. Frame

Each Doz.

16 in. Frame

18 in. Frame

$1.10 \quad 12.00$

20 in. Frame
15.00

18.00

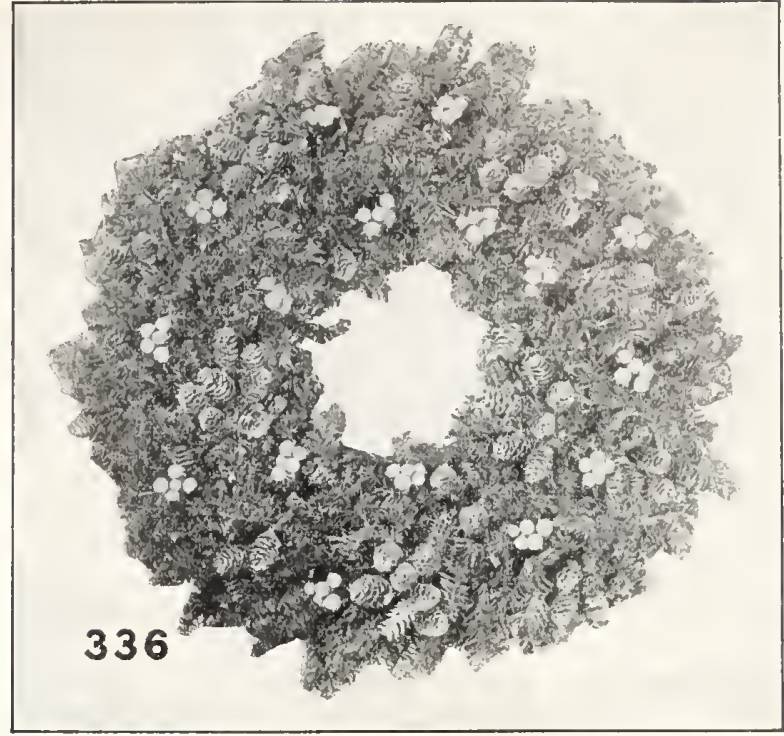

No. $240 / 1$

No. 240/1. Natural green prepared spruce wreath, with decoration of small natural spruce cones and clusters of red florabutts. A wreath fresh from the woods, but prepared to last indefinitely. 14-inch frame; 22 inches overall. $\$ 3.00$ each.

See page 61 for complete list of Florists' Wire Designs.

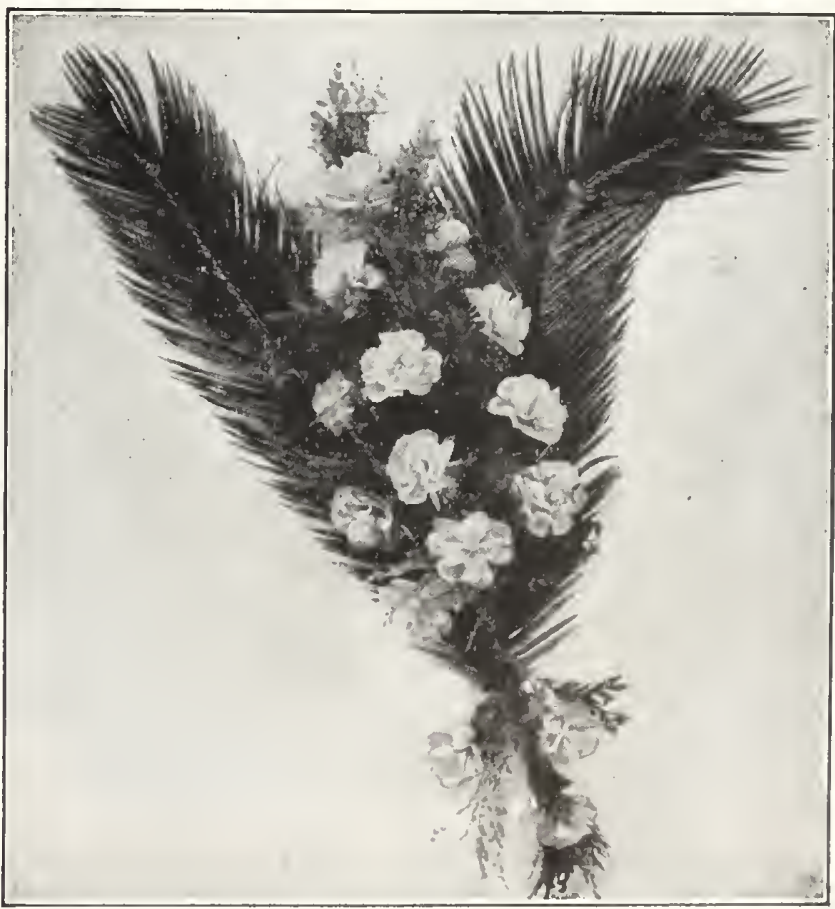

No. $76 / 30$

No. 76/30. Green cycas spray with trimmings in assorted wax flowers and in different colors. 30 inches long, $\$ 2.00$ each. 


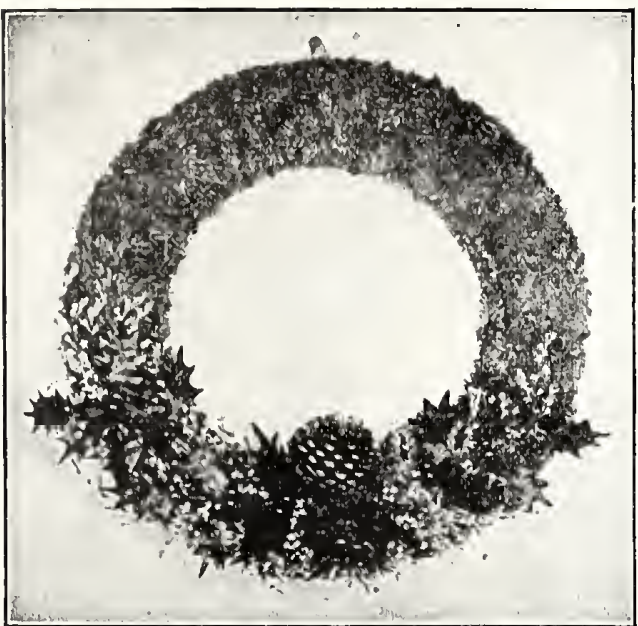

Trimmed Red Frieze Wreath

\section{TRIMMED RED FRIEZE WREATHS}

Made in two styles of trimming and on halfround wreaths. All packed singly in boxes.

No. Each Per doz.

$\$ 0.35$
$\$ 4.00$

No. 3/8. 8 in. $\operatorname{diam} . \ldots \ldots . .45 \quad 5.00$

No. $3 / 10.10$ in. diam....... $.60 \quad 6.50$

No. 3/12. 12 in. diam....... .75 8.50

No. $3 / 14.14$ in. diam.

$\begin{array}{rr}1.00 & 10.00\end{array}$

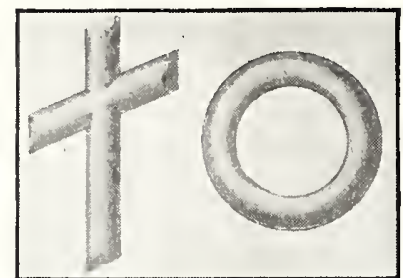

Wreath Form

CARDBOARD CROSS FORMS

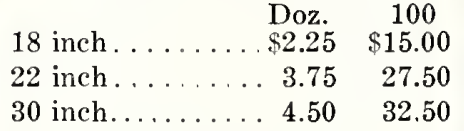

\section{CARDBOARD WREATH FORMS}

\begin{tabular}{|c|c|c|}
\hline diam & $\begin{array}{c}100 \\
\$ 0.65\end{array}$ & $\begin{array}{l}1000 \\
\$ 5.25\end{array}$ \\
\hline in. diam. & 1.00 & 7.75 \\
\hline in. diam. & 1.25 & 10.00 \\
\hline in. diam. & 2.25 & 18.00 \\
\hline a. diam. & 3.75 & 30.00 \\
\hline diam. & 4.50 & 36.00 \\
\hline diam. & 5.00 & 45.00 \\
\hline dian & 7.50 & 67.50 \\
\hline d & 12.0 & 115.00 \\
\hline
\end{tabular}

\section{CARDBOARD STAR FORMS}

Per 100

4 inch

6 inch

7 inch

9 inch

$12 \mathrm{inch}$

PINE CONES

(Assorted Colors) 100 in carton. Small, $\$ 2.50$ per 100 ; Medium, $\$ 3.50$ per 100; Large, $\$ 5.50$ per 100 .

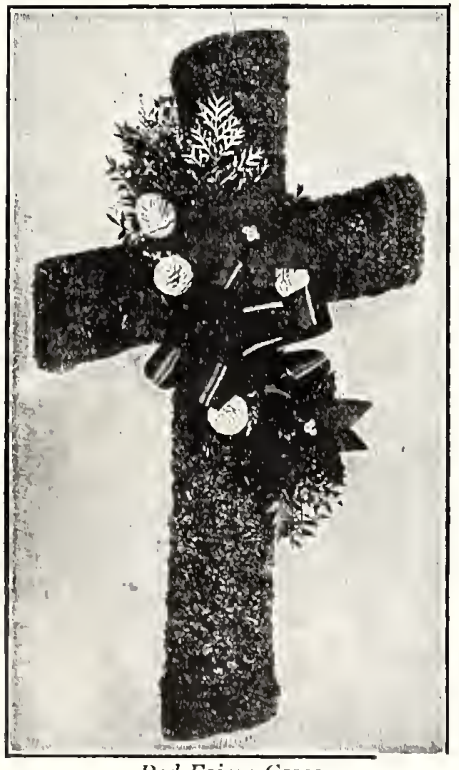

Red Frieze Cross
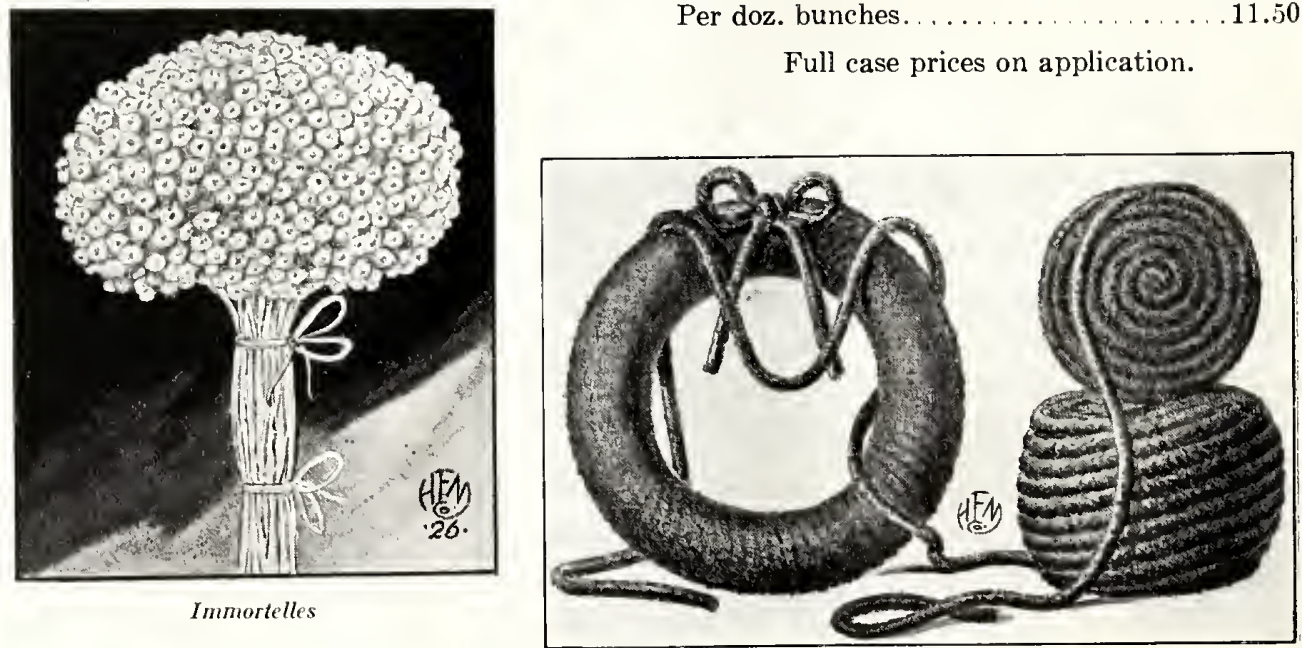

\section{RED FRIEZE CROSS}

Trimmed with ribbon, cones, poinsettias and leaves.

Each

No. 7. 18 in. high....... \$1.10

No. $7 / 2.22$ in. high......... 1.50

Per doz. bunches.

11.50

Full case prices on application.

\section{FRIEZE ROPING}

This is extensively used for decorating at the Christmas season; economical yet effective; fresh, fluffy stock, $3 / 4^{-}$ inch wide; a wide range of bright colors. Christmas Red, Green, Purple, Blue and White; 60 yards per ball. Price
$\$ 1.00$

2.25

3.00

4.00

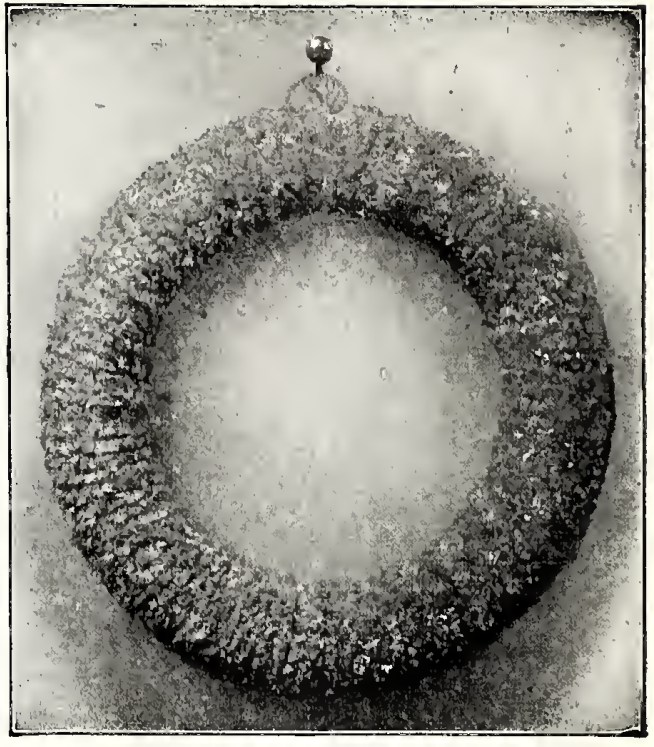

Red Frieze Wreath

\section{PLAIN RED FRIEZE WREATHS}

No. 2. Whole-round.

Size

Per doz.

No. $2 / 6 . \quad 6$ inch.............. $\$ 2.00$

No. $2 / 8 . \quad 8$ inch.............. 3.25

No. 2/10. 10 inch............... 4.00

No. 2/12. 12 inch............. 5.00

No. 2/14. 14 inch.............. 6.50

No. $2 / 16.16$ inch..... . . . . . . . . . 8.50

\section{IMMORTELLES}

New imported stock; large, full sized bunches; bright shades of red and purple.

Per bunch

$\$ 1.00$ per ball, 50c.; $\$ 4.75$ per 12 balls; per 100 balls, $\$ 35.00$. 


\section{MICHELL'S FLORISTS SUPPLIES}

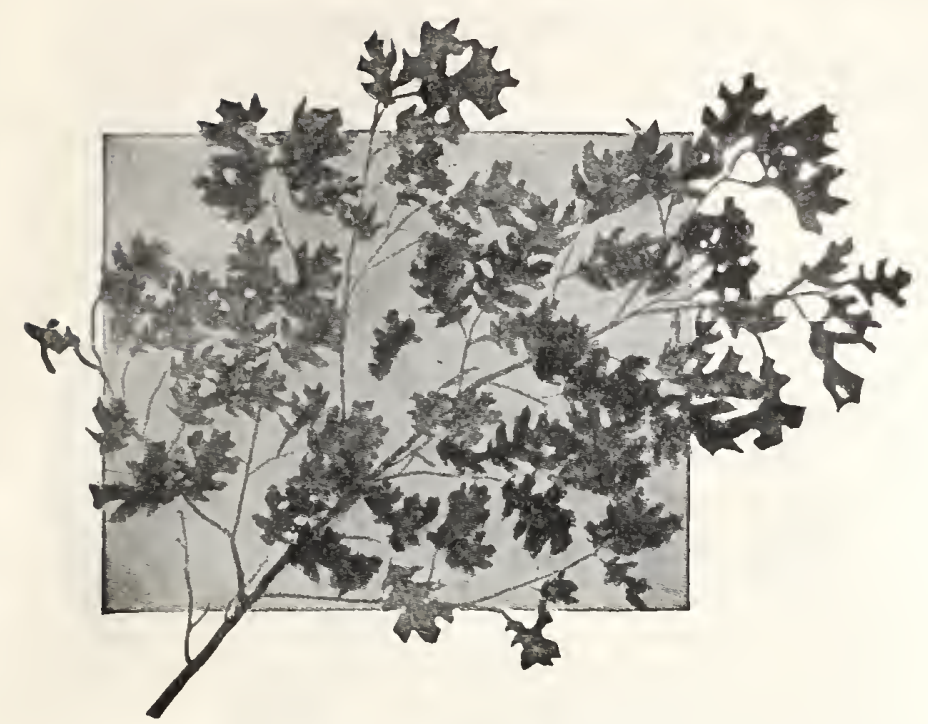

OAK LEAF SPRAYS

Natural preserved long sprays for decorative work; colors, red, brown and green. 25 lbs., $\$ 7.00 ; \$ 13.50$ per 50 lbs.; 100 lbs., $\$ 25.00$.

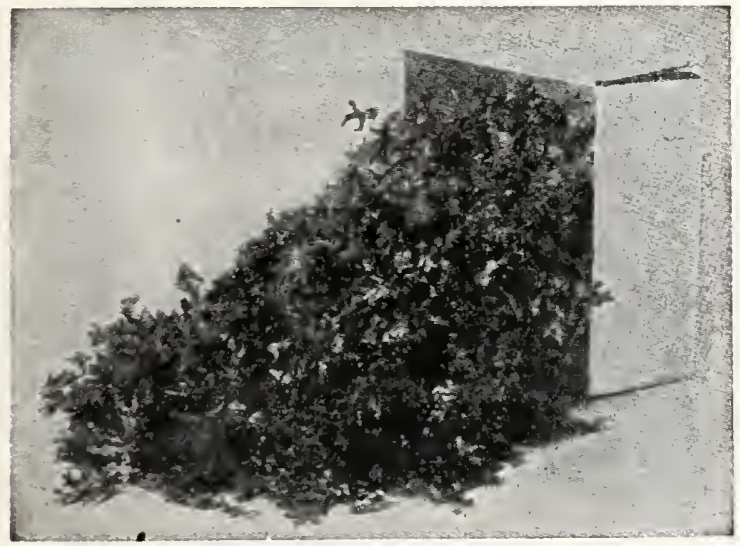

\section{CARTON OAK}

Small oak twigs especially adapted for wreath, wreathing or basket work. Colors, red, brown and green. 5 lbs., $\$ 2.00 ; \$ 6.75$ per $25 \mathrm{lbs}$.

\section{THE FLORISTS FRIEND}

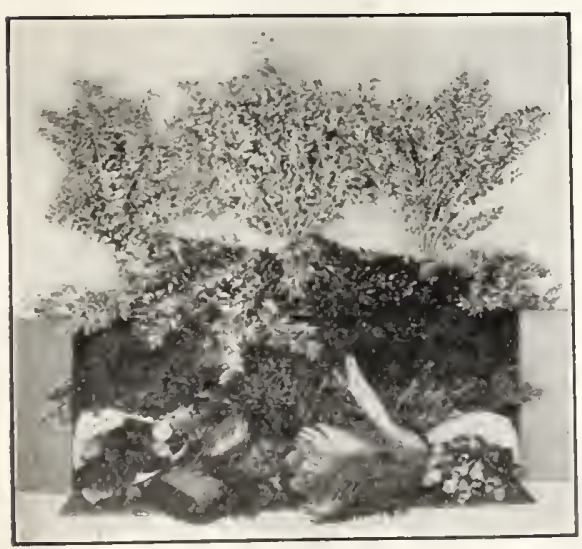

An extensive assortment of natural prepared items for wreath decorations and basket fillings, put up in an attractive carton, consisting of the following: $1 \mathrm{lb}$. assorted metallic ruscus; $1 \mathrm{lb}$. assorted tinted ruscus; 20 assorted metallic cycas; 50 assorted poppy pods: 50 assorted thistles; $1 / 2 \mathrm{lb}$. assorted dyedstatice. Just the thing for your Christmas and Memorial Dayneeds. Special price, $\$ 8.00$.

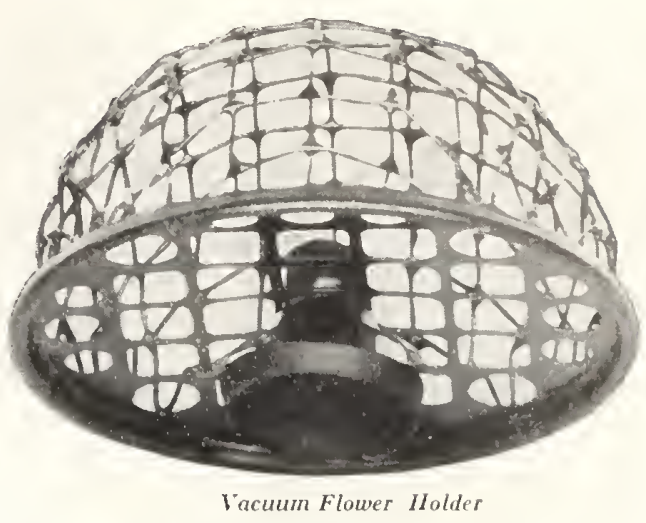

\section{VACUUM FLOWER HOLDER}

Made of metal, round shape, with square wire mesh dome. Finished in green bronze, with rubber vacuum cup in bottom, which prevents tilting over, when long stemmed flowers are used. A great seller for the florist.
No. 1. Small size
Each Doz
No. 2. Medium size
$\$ 0.35 \$ 3.50$
No. 3. Large size

\section{DAZEY FLOWER HOLDER}

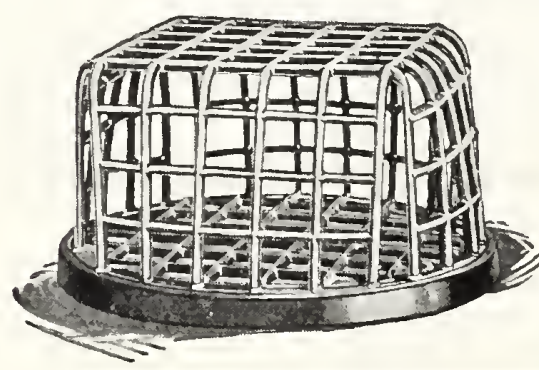

A heavy wire block flower arranger. Used in the center of flower bowls and baskets. Enameled green.

Diam. Size

of of Per

No. Base Mesh Doz.

G0 7 in. $7 / 8$ in. $\$ 18.00$

G1 $51 / 4$ in. $3 / 4$ in. $\quad 9.00$

G2 4 in. $1 / 2$ in. 7.20

G3 $31 / 2$ in. $1 / 2$ in. $\quad 5.40$

G4 $21 / 4$ in. $1 / 2$ in. 3.60

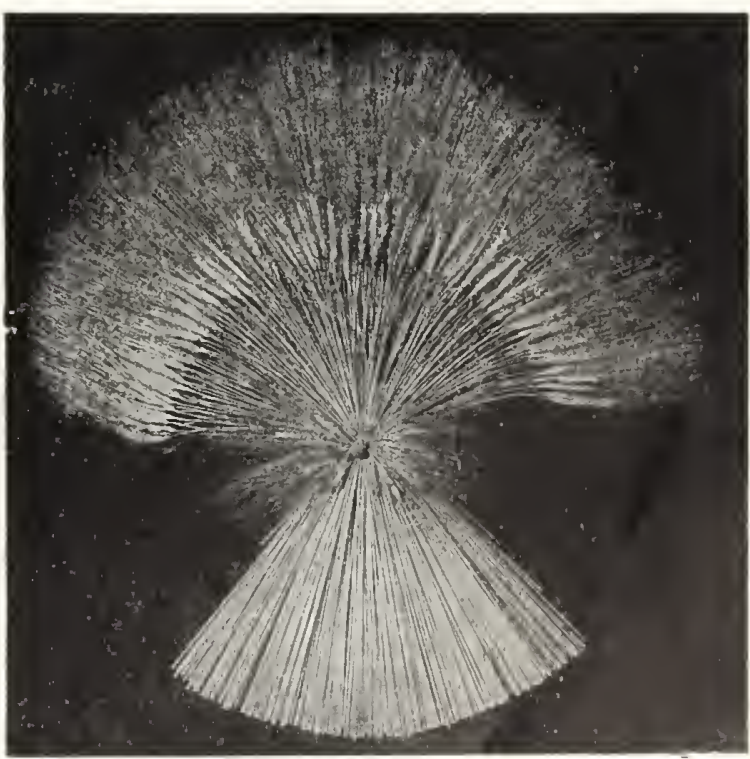

\section{WHEAT SHEAVES}

Extra heavy weight, fluffy stock; made of Selected Bleached Italian Wheat, by expert designers.

No. 1. $-15 \frac{1}{2}$ inch, flat

No. 2. -17 inch, flat

No. 3.-19 inch, flat

No. 4. -22 inch, flat

No. 5.-24 inch, flat.
Each Doz.

$\$ 0.50 \$ \$ 5.00$

$.60 \quad 7.00$

$.75-8.75$

$1.00 \quad 11.00$

$1.25 \quad 14.00$ 


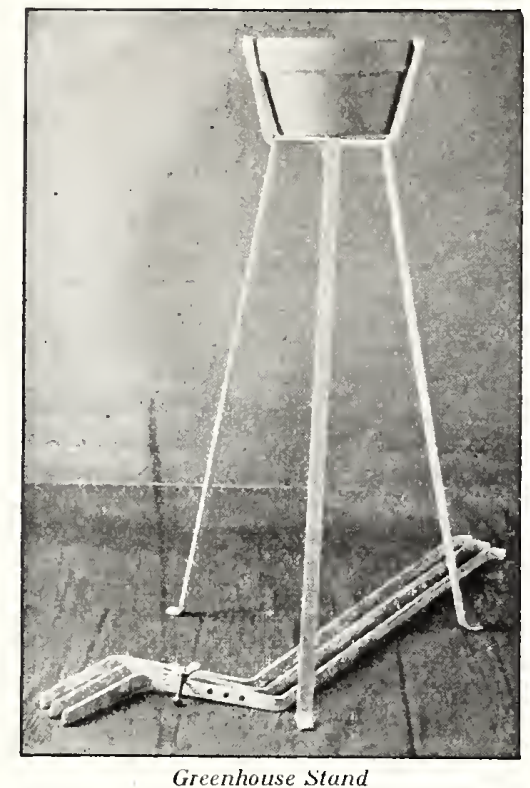

\section{KIFT'S PREMIER GREENHOUSE STAND}

Adjustable to hold 8, 9 or 10 inch pots, pans or tubs; 28 inches high. $\$ 1.50$ each; doz., $\$ 17.00$; $\$ 125.00$ per 100 .

\section{KIF'T'S PREMIER} PLANT STAND

Made of steel in three sections, heavily coated with palm green enamel. The 12,18 and 24 inch heights will hold 6 to 8 inch pots; the 30 and 36 inch heights will hold 9 to 10 inch pots.

Each

18 inch . . . . . . . 1.25

24 inch . . . . . . . 1.50

30 inch........ 1.75

36 inch . . . . . . . 2.00

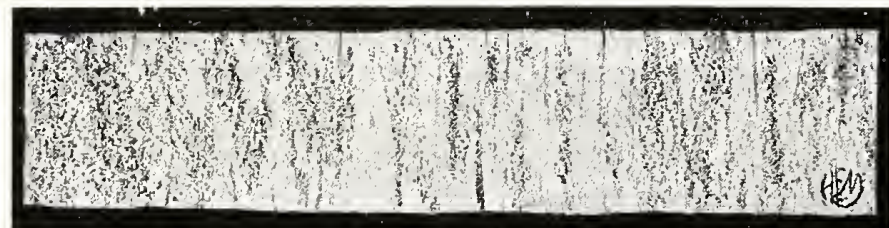

Birch Bark

\section{BIRCH BARK}

For use in covering window boxes and for baskets and decorations. Comes in sheets from 18 to 24 inches in width, runs about 10 feet long, weighs from 2 to 4 lbs. to the sheet.

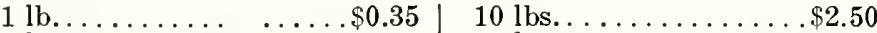

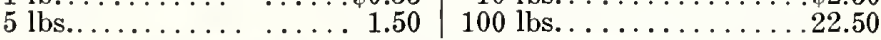

\section{RED CEDAR BARK}

For covering window boxes, baskets or any other article. Per sq. ft., $12 \mathrm{c}$.; $\$ 2.25$ per 25 sq. ft.; 50 sq. ft., $\$ 4.00$.

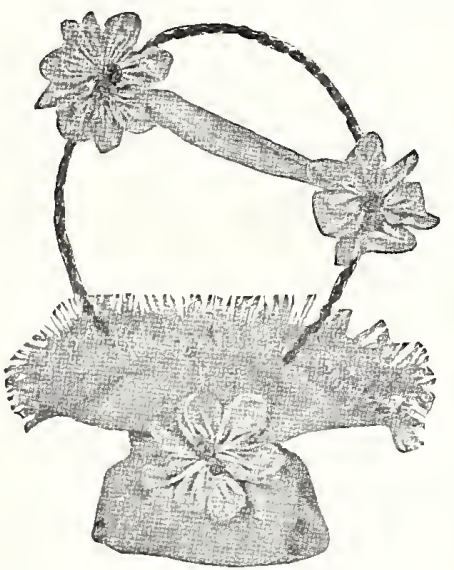

HANSON

HANDY HANDLE

With the Saw Tooth Grip

Fits any size flange. Colors: lavender, pink, blue, yellow, purple, nile green, red and green. Price, double wound in reed, $\$ 3.25$ per doz.; per $100, \$ 25.00$.

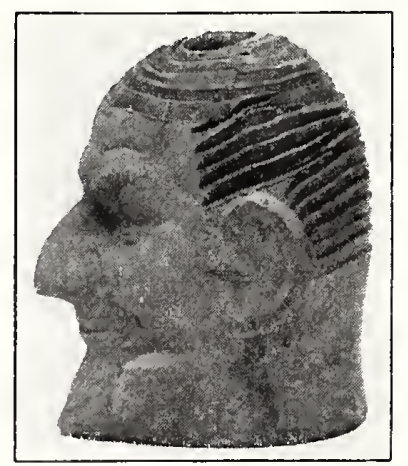

\section{EARTHEN} GRASS HEADS

This novelty has created quite a demand for itself. They are very interesting to watch developing. Seed sown thereon usually sprouts in from 4 to 5 days. Full directions and package of seed with each. Price, 50c. each; doz., $\$ 5.50$.

\section{NEW PHILLY FERN PIN}

A distinct achievement of real value to every florist.

Easier to push in place.

Easier to handle.

Easier on the fingers.

\section{The Bend Holds the Leaves Firmly}

No danger of leaves breaking loose as with the old-style pin. The S-shaped top presses securely on the leaf and the leaf stays where you put it.

\section{And they cost no more than ordinary pins}

\section{$\$ 2.25$ per $10 \mathrm{lb}$, box.}

$\$ 20.00$ for 10 boxes.

$\$ 19.50$ per $100 \mathrm{lb}$. carton.

Illustration shows the Philly Pin when on leaf. Notice how flat it lays and the firm hold it takes.

\section{GREENING OR FLORISTS HAIR PINS}

Save valuable time in making designs. Price, $\$ 2.00$ per $10 \mathrm{lb}$. box.
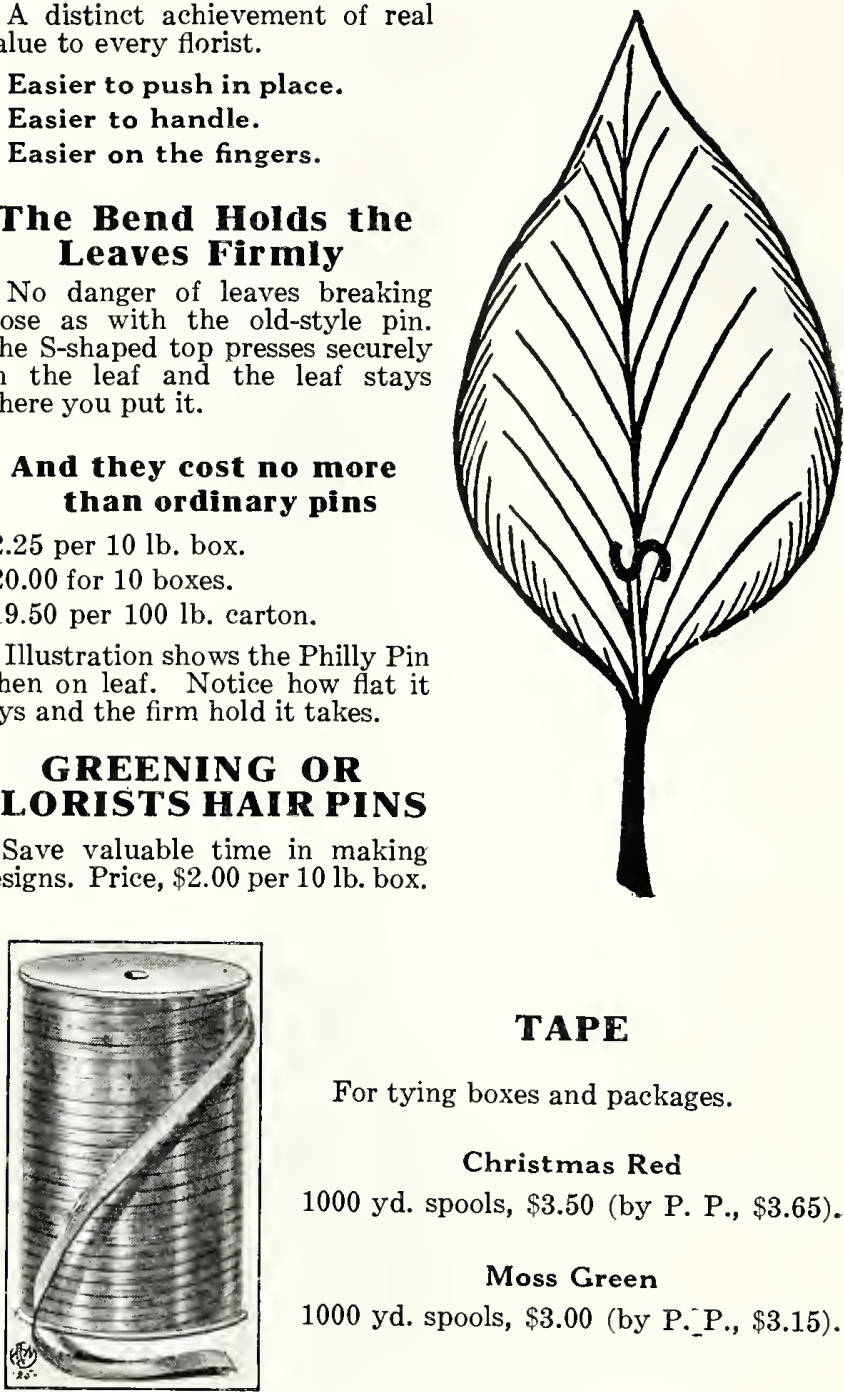

TAPE

For tying boxes and packages.

Christmas Red

1000 yd. spools, $\$ 3.50$ (by P. P., $\$ 3.65$ ).

Moss Green

1000 yd. spools, $\$ 3.00$ (by P._P., $\$ 3.15$ ).

\section{CORSA gE PINS}

The finest indestructible, domestic bouquet and corsage pin made; colors: Violet, Pink, Red, Green, Pearl and White.

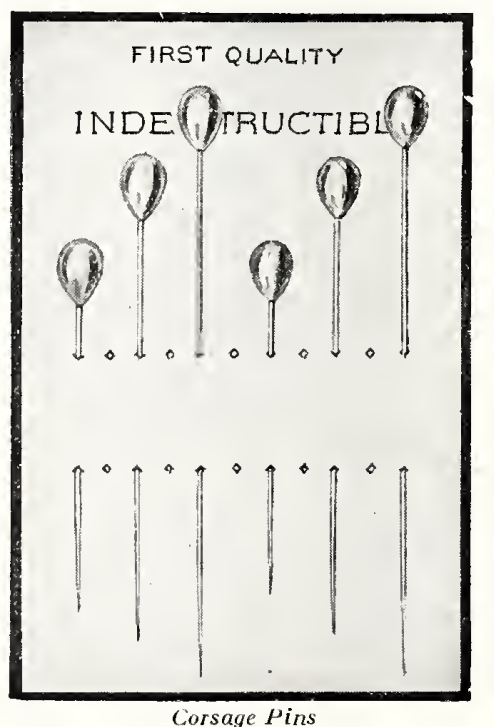

No. 13. Pear shaped, all colors.

Per gross

3 inch

4 inch............. 2.25

5 inch...........2.25

No. 14. Pear shaped, Violet and Green.

3 inch . Per gross

4 inch............ 1.50

5 inch........... 1.50

No. 15. Pear shaped, all colors. Mottled.

Per gross

inch..........\$2.25

4 inch........... 2.25

5 inch............ 2.25

No. 14F. Flat Head. Violet only.

Per 1000

21 inch...... \$3.25

3 inch............ 3.50

$31 / 2$ inch......... 3.75

4 inch......... 4.00 


\section{MICHELL'S FLORISTS SUPPLIES}

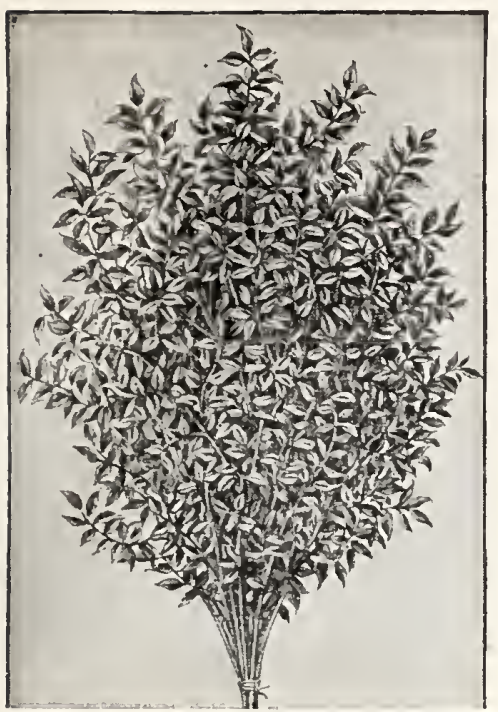

RUSCUS

Green (Painted). Per lb., 60c.; 10 lbs., at $50 \mathrm{c}$. per lb.; 100 lbs., $\$ 45.00$.

Green (Dyed). 85c. per lb.; $10 \mathrm{lbs}$. at 75c. per lb.; 25 lbs. at 70c. per lb.; 100 lbs., $\$ 65.00$.

Christmas Red. Per lb, 85c.; 10 lbs. at 75 c. per lb.; 25 lbs. at 70c. per lb.; 100 lbs., $\$ 65.00$.

Two-toned. Per lb., $\$ 1.10 ; 5$ lbs. at $\$ 1.00$ per lb.

Metallic (Assorted). Per lb., \$1.25; 10 lbs. at $\$ 1.00$ per lb.

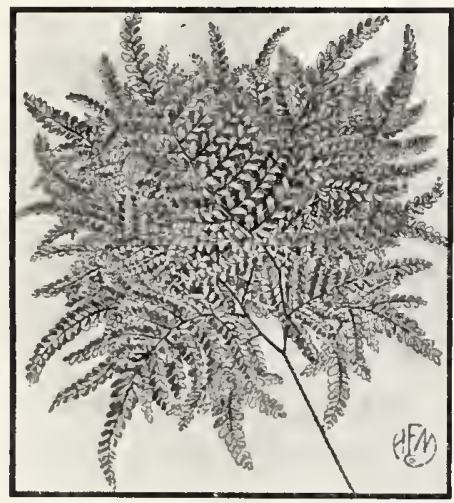

Adiantum, or Maiden IIair Fern

\section{ADIANTUM, OR MAIDEN HAIR FERN}

Per 100

Small..................... \$5.00

Medium.................... 7.00

Large........................ 8.50

Broken Adiantum. Per lb., $\$ 2.25 ; \$ 20.00$ per $10 \mathrm{lb}$. carton.

PREPARED ASPARA GUS

The natural sprays chemically treated and preserved.

Per 100

Small, 15 in. long.............. \$8.00

Medium, 24 in. long . . . . . . . . . . . 11.00

Large, 30 to 36 in. long. . . . . . . . . 12.50

\section{ASPARAGUS TIPS}

Selected quality; valuable between artificial flowers, bouquets and wreaths. $\$ 2.00$ per lb.

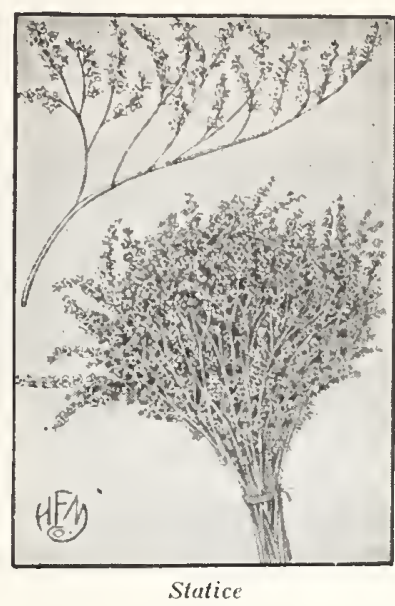

STA TICE

Natural. Per lb., 60c.; 10 lbs. at 50c. per lb.; 25 lbs. at $40 \mathrm{c}$, per lb.; 100 lbs., $\$ 35.00$. Colored (assorted colors dyed). Blue, green, pink, purple and lavender. $\$ 1.25$ per lb.; 5 lbs., at $\$ 1.10$ per lb.; 10 lbs. at $\$ 1.00$ per lb.

Special prices on case lots

\section{CAPE FLOWERS}

(About 1000 to a lb.)

Used considerably in funeral work, taking the place of carnations.

Natural. $\$ 1.25$ per $\mathrm{lb}$.

Dyed. Colors, red, green, pink, blue, purple, orange and mixed. $\$ 2.00$ per $\mathrm{lb}$.

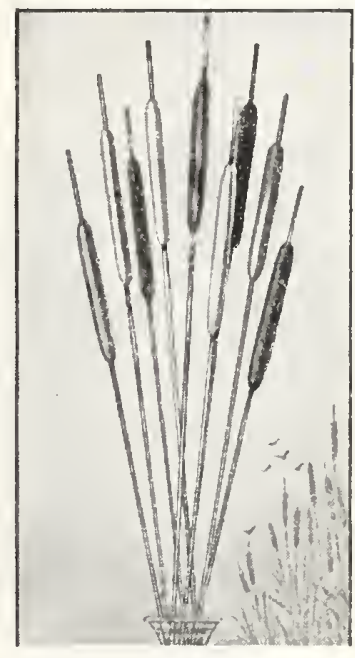

Cat Tails

CAT TAILS

Natural

Per

100

Tinted, all colors......... 3.00

$1 \mathrm{lb}$.
$5 \mathrm{lbs}$
$10 \mathrm{lbs}$
$25 \mathrm{lbs}$
$100 \mathrm{lbs}$

LYCOPODIUM

(Prepared and Dyed Green

$1 \mathrm{lb}$.

10 lbs....

25 ibs.

6.75

.25 .00

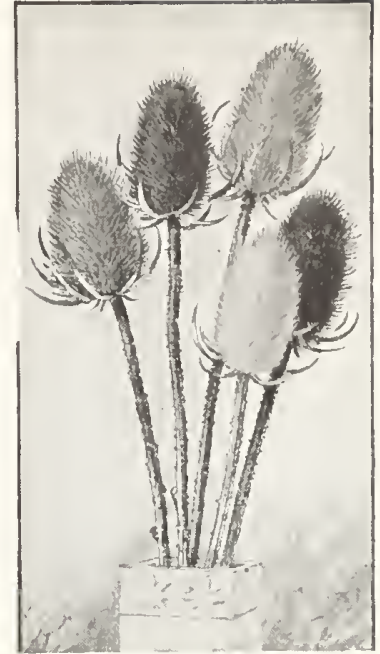

THISTLES

Plain, tinted and polychrome. In cartons containing an assortment of these colors. Per carton of $100, \$ 2.50 ; \$ 20.00$ per 1000 .

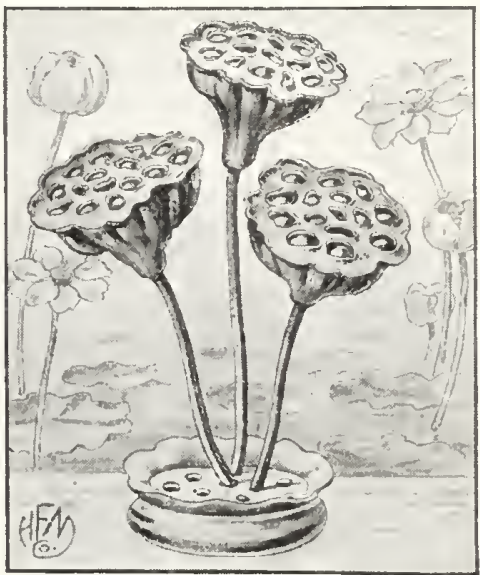

\section{LOTUS PODS}

Very effective for basket, vase or wreath (without stems, 100 to a carton).

Two-toned, per $100 \ldots \ldots \ldots \ldots \$ 7.50$

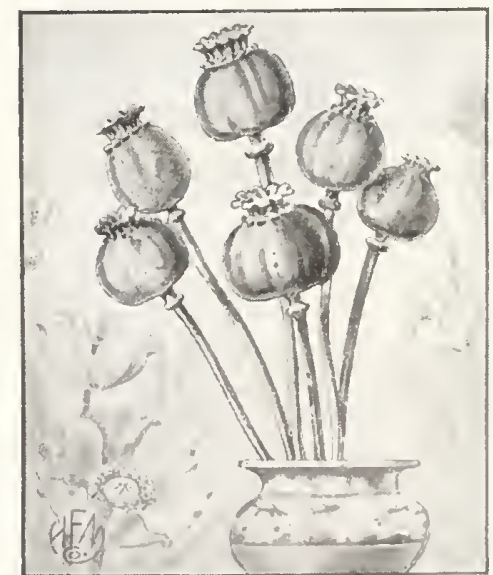

MOON BLOSSOMS, OR POPPY HEADS (Large)

Per 100 Per 1000 


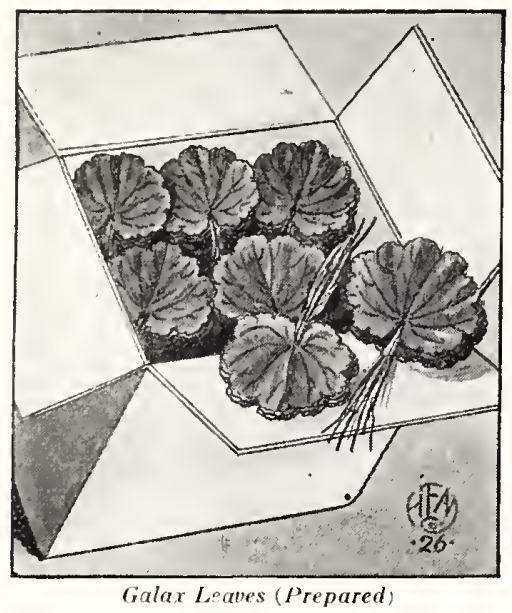

GALAX LEAVES (Prepared) (2000in carton)

Per 1000 Per carton

Green or Brown ....... \$2.50 $\$ 4.50$

\section{MA GNOLIA LEA VES}

Extra selected grade (Dux Brand).

We can supply these in green, bronze or brown and purple; extra fine quality. Standard cartons, $\$ 1.50 ; \$ 14.50$ per 10 cartons.

$50 \mathrm{lb}$. cases

$100 \mathrm{lb}$. cases

Red leaves, per carton............. 1.60

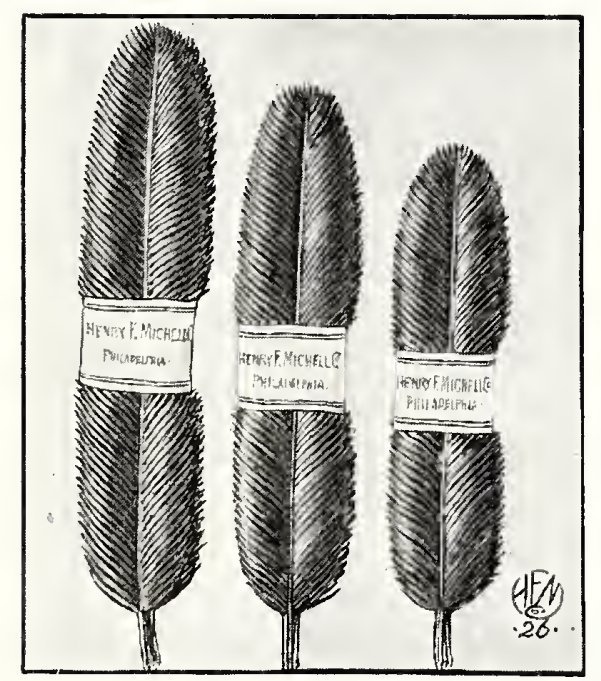

\begin{tabular}{|c|c|c|}
\hline \multicolumn{3}{|c|}{ CYCAS LEAVES (Green) } \\
\hline & Per 10 & Per 100 \\
\hline $6 / 8$ inch & $\ldots \$ 0.30$ & $\$ 2.75$ \\
\hline $8 / 12$ inch & .35 & 3.00 \\
\hline $12 / 16$ inch & .40 & 3.50 \\
\hline $16 / 20$ inch & .45 & 4.00 \\
\hline $24 \mathrm{inch}$ & .60 & 5.00 \\
\hline $4 / 28$ inch & .70 & 6.00 \\
\hline $28 / 32$ inch & .85 & 7.00 \\
\hline 32 & .95 & 8.00 \\
\hline $36 /$ & 1.10 & 10.00 \\
\hline $40 / 44$ inc & $\therefore 1.25$ & 11.50 \\
\hline $44 / 4$ & 1.40 & 13.50 \\
\hline
\end{tabular}

\section{CYCAS LEAVES (Metallic)}

Per 10 Per 100

$8 / 12$ inch . . . . . . . Pe. $\$ 0.60 \quad \$ 5.00$

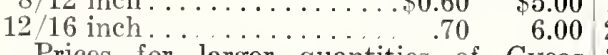

Prices for larger quantities of Cycas

Leaves on application.

\section{ARTIFICIAL LEA VES}

High grade leaves for stemming or design work.
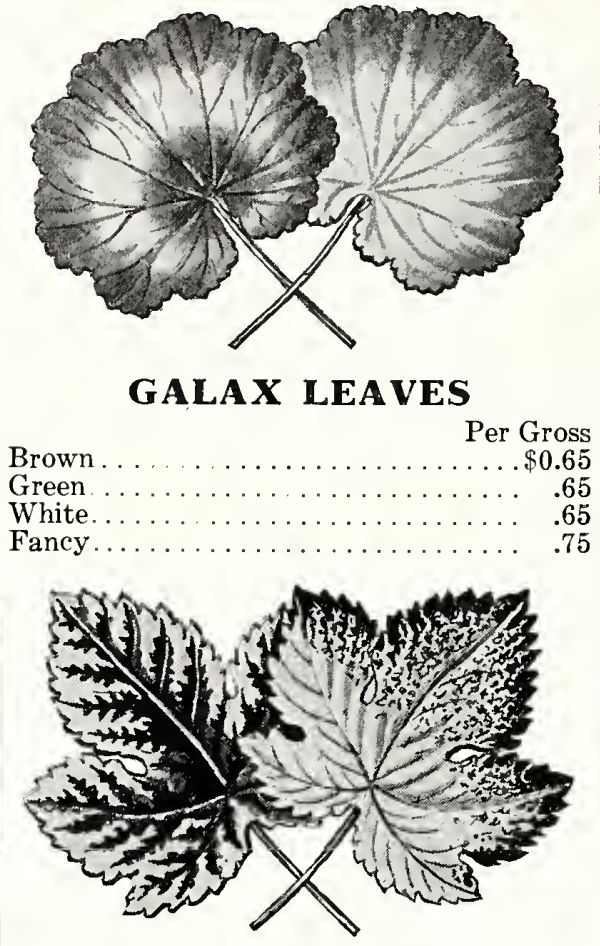

MAPLE LEAVES

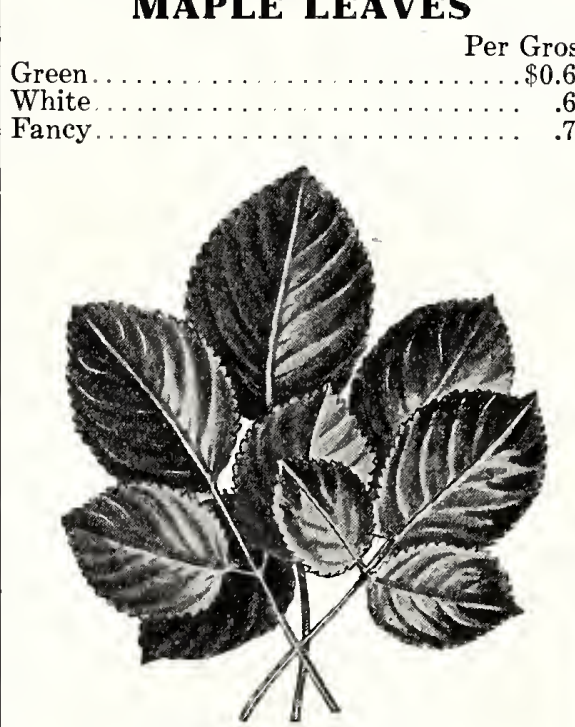

ROSE LEAVES

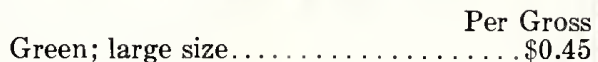

Green; small size . . . . . . . . . . . . .40

Shaded; large size . . . . . . . . . . .45

Shaded; small size.

\section{ARECA PALM LEAVES (Prepared)}

New crop of excellent quality.

Bundle of $25 \quad 100$

$18 / 24 \ldots \ldots \ldots \ldots \ldots \ldots 2.25 \quad \$ 8.00$

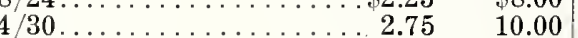

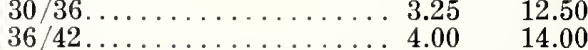

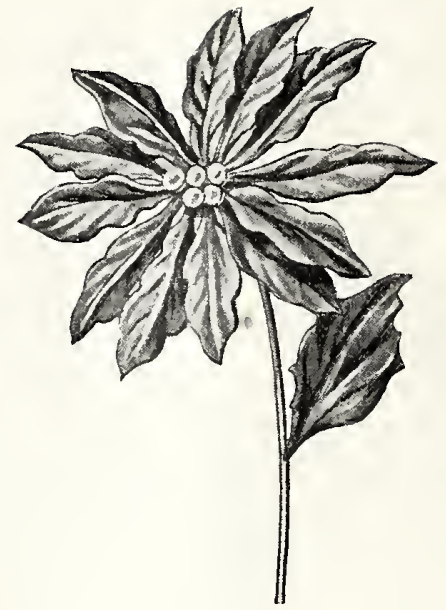

POINSETTIAS

Doz. Gross

No. 149. Velvet.......... . $30 \quad 2.75$

No. 1204. Velvet.......... $1.65 \quad 18.00$

No. 306. Velvetine.......... $1.00 \quad 10.00$

No. 309. Velvetine.......... $1.50 \quad 14.50$

No. 9161. Lacquered........ $1.50 \quad 15.00$

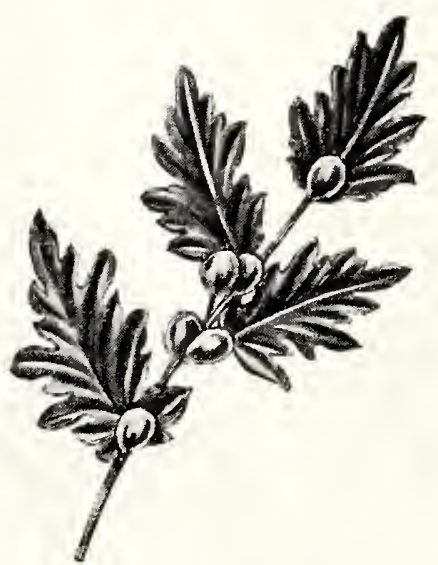

\section{HOLLY SPRAYS}

With Red Berries

No. 0150. Groens

No. 0152. Green leaves........... 5.00

No. 0161. Gold or silver leaves. . . . . 5.00

No. 0205. Gold or silver leaves.... . . 2.50

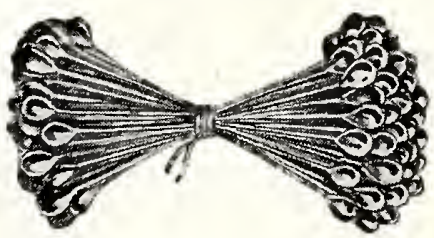

HOLLY BERRIES (On Stems)

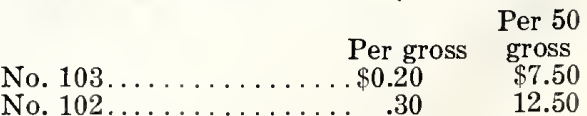

No. $102 \ldots \ldots . . . . .20 \quad \$ 0.20$

ARTIFICIAL MISTLETOE

14.00 No. 0164. Per gross............\$2.25 


\section{MICHELL'S FLORISTS SUPPLIES}

\section{ARTIFICIAL FLOWERS (Crepe)}

Suitable for wreaths and design work; best quality imported and domestic grades.

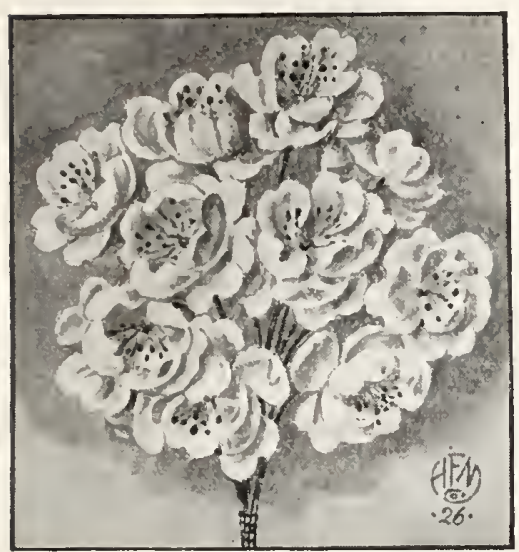

APPLE BLOSSOMS

No. 300. White, Pink, Lavender. Per gross.

\section{ASTERS}

No. 19. Pink, Lavender, White. Per 100 . . . .

\section{CORNFLOWERS}

\section{Bachelor's Buttons}

No. 389. Blue. Per gross........

\section{DAISIES}

No. 361. White, Yellow, Coral. Per gross

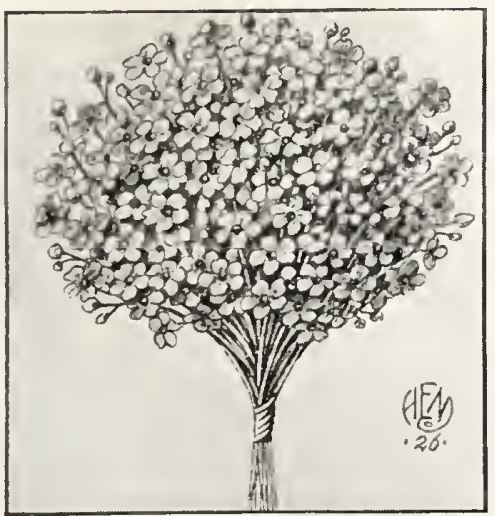

FOR GET-ME-NOTS

No. 490. Blue. Per gross........ \$1.50

\section{HYACINTHS}

No. 110. White, Pink, Lavender. Per gross

\section{NARCISSUS}

No. 344. Pink, White, Yellow. Per gross.

\section{ORCHIDS}

No. 25. Lavender, Pink, White with Lavender center. Per $100 \ldots \ldots \ldots \ldots . \$ 4.50$

\section{PANSIES}

No. 5. Lavender, Purple, Yellow, Lavender and White. Per $100 \ldots 1.50$

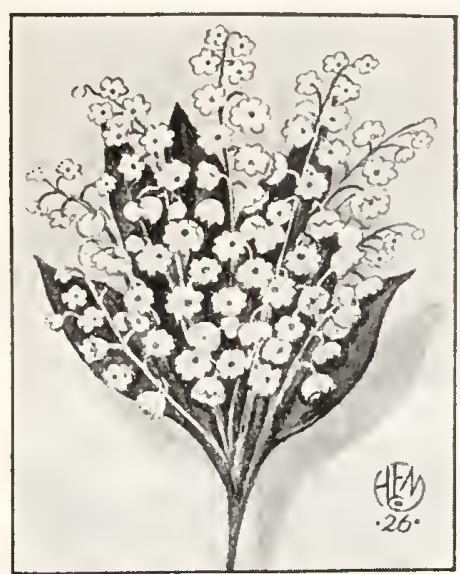

\section{LILY OF THE VALLEY}

No. 500. White. Per gross....... \$1.50

\section{POETICUS}

No. 105. White, Pink, Lavender.

\section{ROSES}

No. 47. Pink, White, Lavender, Tinted, Per 1000 Yellow, Ward, Red, Pink Tint.

Per gross...................\$3.00

\section{RAMBLER ROSES}

No. 289. Pink, White. Per gross..... \$2.25

\section{WAX FLOWERS}

Finest quality, heavily waxed.

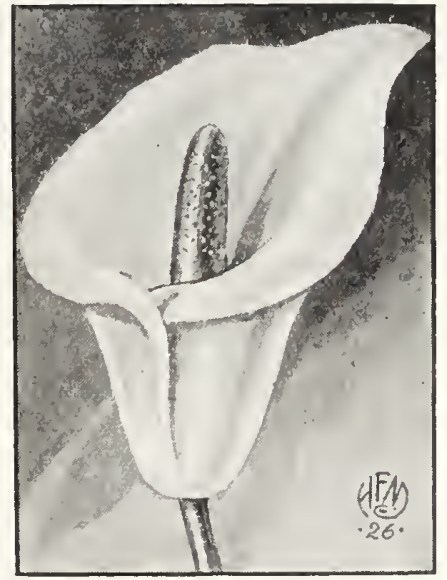

CALLA LILIES

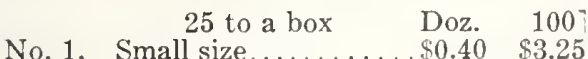
No. 2. Large size........ $\quad .50 \quad 4.00$

\section{CARNATIONS}

Pink and White; 100 to a box. Per $100, \$ 1.75 ; \$ 15.00$ per 1000 .

\section{CAPE FLOWERS (Paper)}

Blue, Lavender, Pink, Red and White. 2000 to box.

Per 1000 .
WAX FLOWERS - Continued

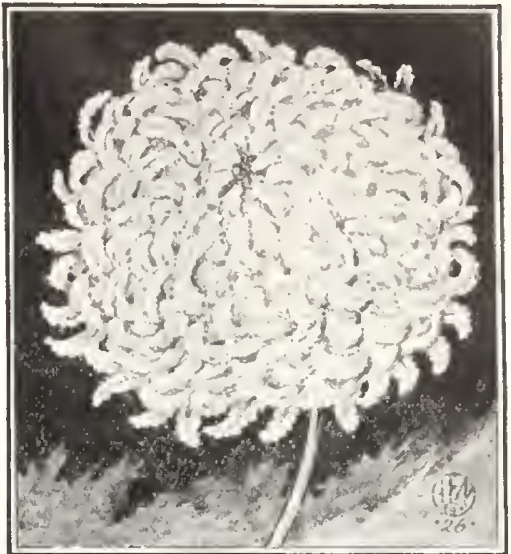

\section{CHRYSANTHEMUMS}

Lavender, Pink, White and Yellow. 100 to a box.

Per 100

$\$ 3.00$

Per 1000

25.00

\section{DAHLIAS}

Lavender, Pink, Purple, Red, White and Yellow. 100 to box.

Per 100

$\$ 2.75$

25.00

\section{EASTER LILIES}

Lavender or White; 100 to box. Per 100

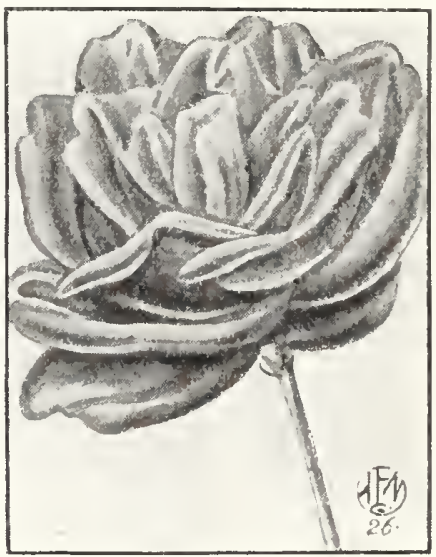

\section{ROSES}

Golden Gate, Pink and White; 100 to box.

No. 1. Small size

No. 3. Large size.............. 2.85

No. A. Special size; tight blossom. -2.25

SWEET PEAS

Lavender, Pink or White; 500 to box. Per $100,55 \mathrm{c}$; $\$ 5.00$ per 1000 .

\section{NATURAL FLOWER DYE}

For tinting fresh cut flowers by absorption through the stem. Yellow, Pink, Red, Blue, Violet, Orange, St. Patrick's Green. Any species of flower which absorbs moisture readily may be used. Directions on each $\$ 4.00$ package. Price, 50c. per pkg. 


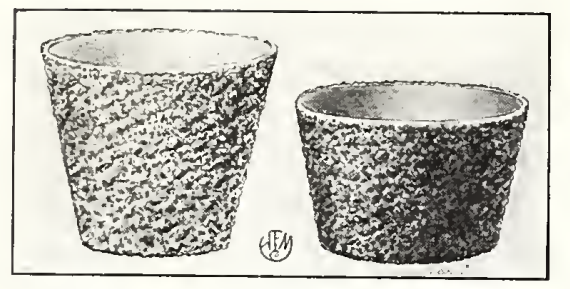

JARDIERS (New Style)

Colors: Green, Ivory, Lavender and Yellow.

4-in. for pots...... $\begin{array}{cccc}\text { Doz. } & 100 & 1000 \\ \$ 2.50 & \$ 18.00 & \$ 160.00\end{array}$ 6-in. for pots ....... $2.75 \quad 20.00 \quad 180.00$ $71 / 2$-in. for bulb pans.. $2.50 \quad 18.00 \quad 150.00$ $81 \frac{1}{2}$-in. for bulb pans.. $3.00 \quad 22.00 \quad 200.00$ $91 / 2$-in. for bulb pans.. $3.75 \quad 27.50 \quad 250.00$ $101 \%$-in. for bulb pans. $4.25 \quad 32.50 \quad 300.00$

\section{JARDIER VASE}

Most practical vase made ; unbreakable ; waterproof ; made of laminated cellulite; beautiful green and ivory tones. Per doz., \$2.50; $\$ 20.00$ per 100 .

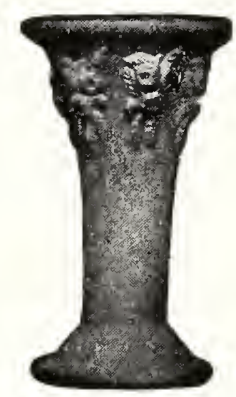

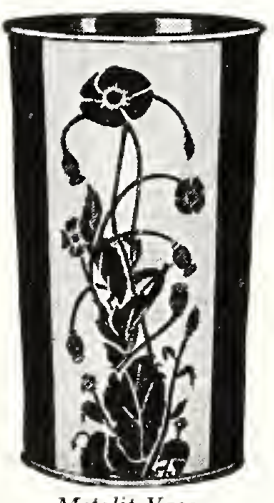

Metolit Vase

\section{METOLIT FLOWER VASES}

Furnished in many attractive designs, with body in assorted colors of old rose, baby blue, ivory, green, gold, etc.; inside and bottom finished in old gold baked enamel. No. Diam. Depth Doz. 64 in. $75 / 8$ in. $\$ 2.00$ 106 in. $93 / 4$ in. 3.00

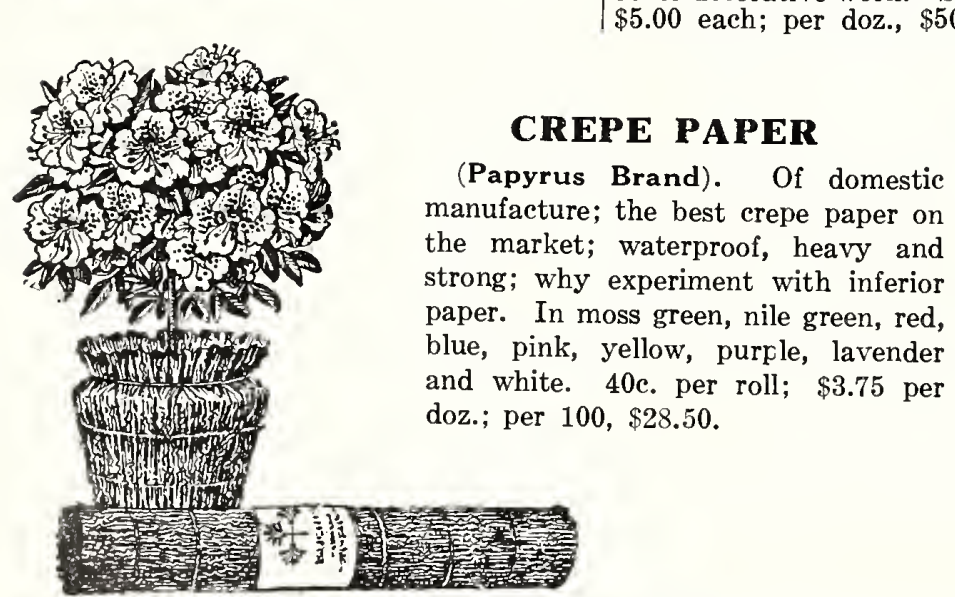

\section{EMPECO JARDINIERE}

PEACOCK DESIGN

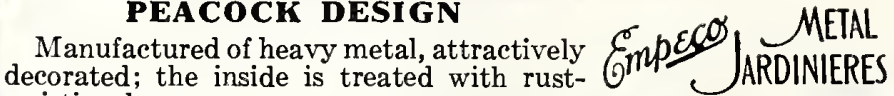
resisting lacquer.

$140 \quad 4$ inch

150

6 inch

7 inch

8 inch

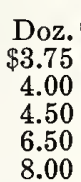

FIBEROC ICE BOX VASE

Made of pulp fibre. Color, walnut and mahogany with gold trim.

Size Height Top diam. Each Doz. A . . . . 81/2 in. $81 / 4$ in. $\$ 0.75 \$ 8.00$

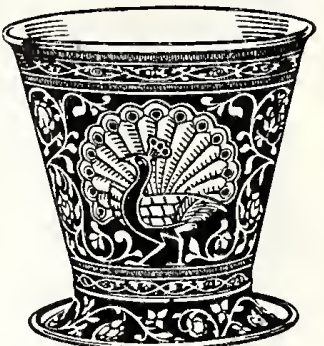
B.....

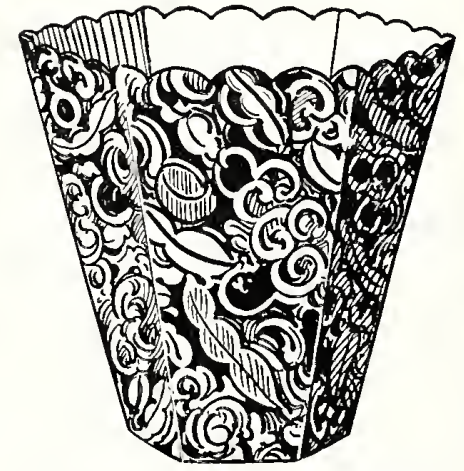

PERMO POT COVERS The New Pot Cover

Made of cardboard; four different designs; very attractive.

5-inch.

Per 100 Per 1000 6-inch .

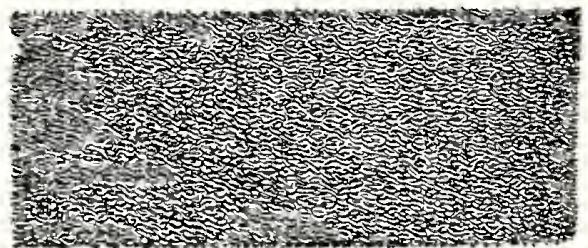

GRASS MATS OR RUGS

Made of Green Raffia on heavy burlap; they closely resemble real grass. Used extensively for store and window trim and in other decorative work. Size $36 \times 72$ inches. other decorative work. Size 36
$\$ 5.00$ each; per doz., $\$ 50.00$.
|FLOWER VASES (Galv. Iron) Top High Bottom No. Diam. In. Diam. Each Doz.

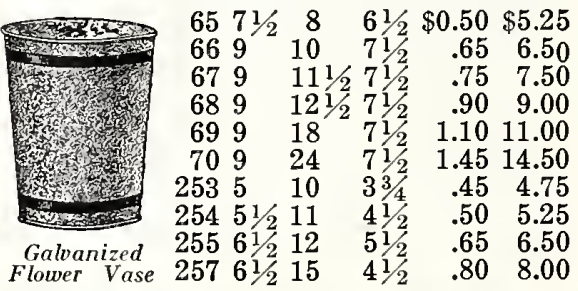

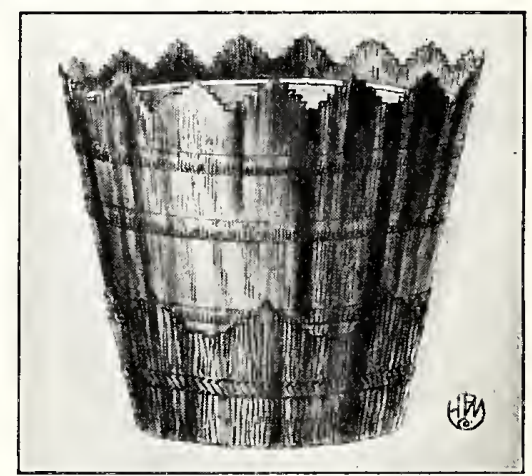

PAPER POT COVERS

Made of waterproof crepe paper; easily adjusted; colors: Green, Red, Pink, Blue and Purple.

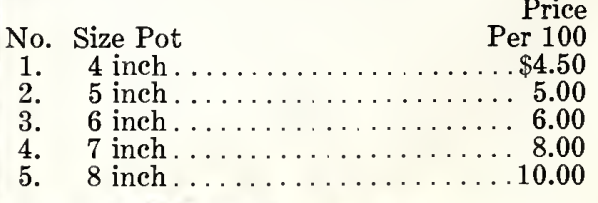

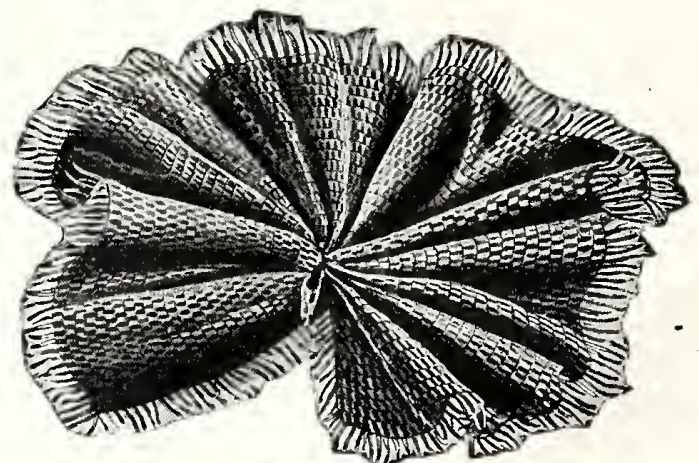

Japanese Mat

JAPA NESE MAT (FOr Pot Covers)

Assorted colors, plain. Doz., 85c.; per 100, $\$ 6.50$. Two-tone colors. Doz., 85c.; per 100, $\$ 6.50$. 
Felt Clock Dials

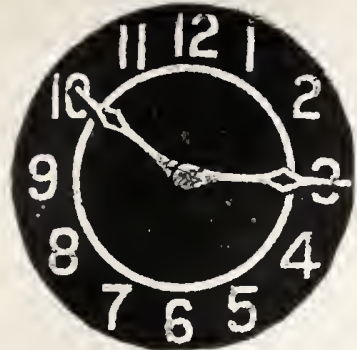

Colors: White and purple and white and gold.

Each Doz.

4 inch..............\$0.35 \$3.50

7 inch.................. .60 5.50

10 inch.............. $1.00 \quad 10.50$

\section{AMERICAN LEGION DESIGNS}

Blue with gold lettering and trimming. $71 / 2$ in.

Doz. 11 in

SCRIPT LETTERS Either in Gold or Purple.

Per 10, 30c.; $\$ 2.50$ per 100 ; per $1000, \$ 20.00$.

Ten words to each package and not less can be supplied.

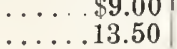

$\begin{array}{lll}\text { Father } & \text { Husband } & \text { Nephew } \\ \text { Mother } & \text { Aunt } & \text { At Rest } \\ \text { Brother } & \text { Uncle } & \text { Son } \\ \text { Sister } & \text { Comrade } & \text { Cur }\end{array}$

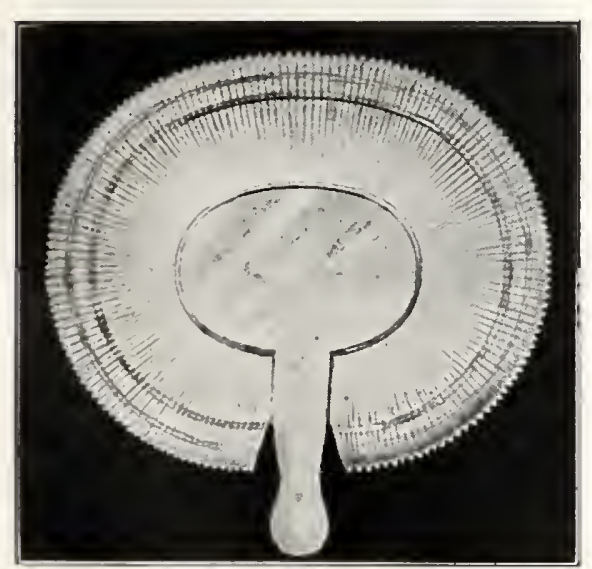

Corsage Shield No. 101

\section{CORSAGE SHIELDS}

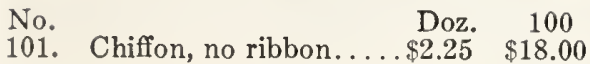

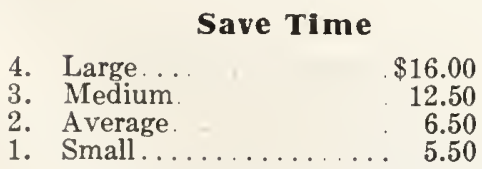

\section{SHOULDER SHIELDS}

Chiffon Edge Shield, in all flower shades. No. 103-A. . Doz. Gross $\$ 2.25 \$ 24.00$
LETTERS FOR DESIGN WORK

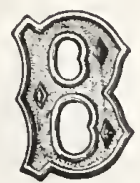

No. 6

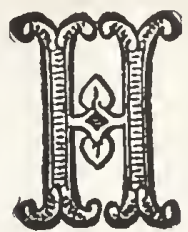

No. 4
No. 6. Gold only; per 100, 40c.; per 1000 , $\$ 2.75$.

No. 4. $3 / 4$ inch, gold only; per $100,40 \mathrm{c}$; per $1000, \$ 2.75$. Also numerals at the same price.

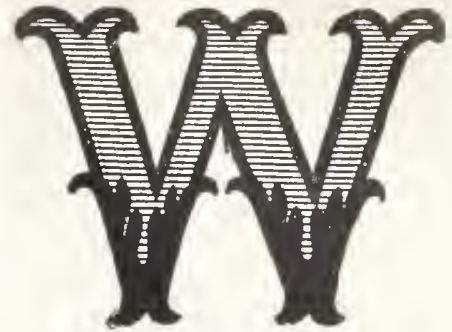

No. 1

No. 1. 11/4 inch, gold only, per $100,50 \mathrm{c}$; per $1000, \$ 3.25$. Also numerals at the same price.

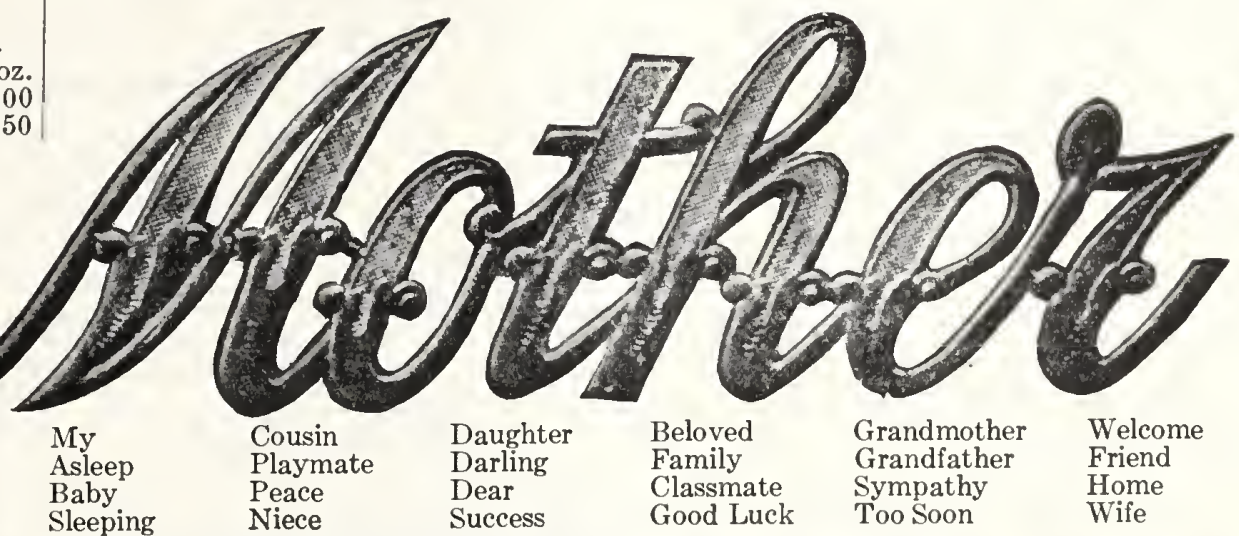

Sleeping

\section{WRIST SHIELDS}

No. 10. With rubber band, chiffon edge; all shades.

Per dozen......

Per gross .............

\section{GOLD STAR BRAND}

FEATHER SHOULDER SHIELDS

No. 104. All colors.

Per dozen. .

Per gross.

$\$ 2.25$

FEATHER WRIST SHIELDS

No. 105. With rubber band and ribbon for tying flowers on; all colors.

Per dozen....

Per gross...

$\$ 2.50$

\section{SINGLE FEATHERS}

Used in the making of bridal and corsage bouquets; all colors.

Per 100 .

Per 1000

$\$ 4.00$ No

$00 \ldots$

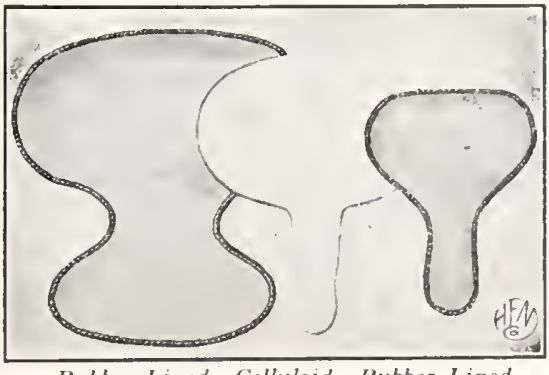

$\$ 2.25$

4.00

25

5.00

Too Soon

Wife

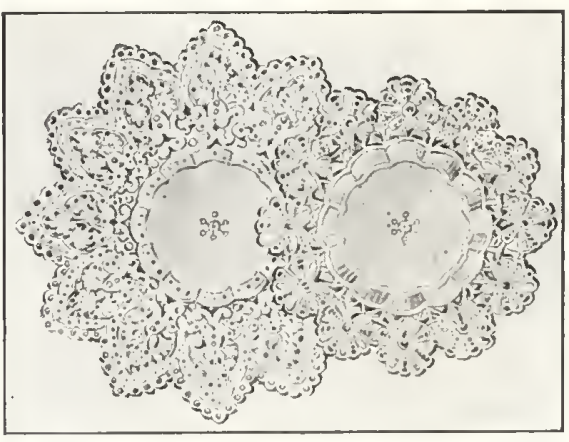

\section{PAPER BOUQUET}

SHIELDS (White)

Made of lace; put up in pkgs. of $1 \mathrm{doz}$. each.

\begin{tabular}{|c|c|c|c|c|}
\hline No & Bowl & Holder & Doz. & Gros \\
\hline 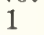 & $11_{2}^{\prime}$ in. & $31 / 2 \mathrm{in}$. & $\$ 0.35$ & $\$ 4.0$ \\
\hline 2 & $21 \%$ in. & $45 / 8$ in. & .40 & \\
\hline 3 & $21 \%$ in. & $51 / 2 \mathrm{in}$. & .45 & \\
\hline 4 & $31 / 4$ in. & in. & .65 & 7 \\
\hline 5 & $37 / 8$ in. & $91 / 4 \mathrm{in}$. & .80 & 9.0 \\
\hline 6 & in. & 11 in. & 1.00 & 10. \\
\hline
\end{tabular}

\section{RUBBERIZED}

CORSAGE SHIELDS

Large, per doz. .

$\$ 1.60$

Small, per doz.

1.00

Celluloid. In 4 colors: Green, Pink, Dull and Transparent. Doz., $85 \mathrm{c} . ; \$ 6.00$ per 100 (See opposite column.) 


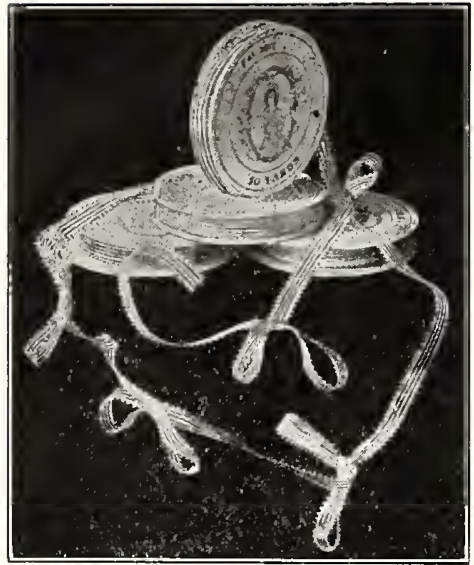

Picot Edge Shower Ribbon

\section{PICOT EDGE SHOWER RIBBON}

Pattern 3013

A dainty shower ribbon with picot edges; delicate yet firm. Colors, White, Pink, Lavender, Blue, Nile and Ward. Put up on 50 -yard reels.

Price per reel, $\$ 1.00 ; 12$ reel lots, at $90 \mathrm{c}$ per reel.

\section{PLAIN EDGE SHOWER RIBBON}

San!e as above, excepting with plain edge, colors the same.

50 -yard reel.

$\$ 1.25$

\section{BARY RIBBON}

For tying cards, etc. 50-yard spools. Each, 70c.

\section{METALLINE OR NEW YORKER}

This is a distinct novelty in ribbons and where something unusual is desired for flower pieces it fills the bill. All colors and color combinations, including tricolor. 6 inches wide; 40 yds. to piece.

Per yd., 8c.; 12 piece lots at $71 / 2 c$. per yd.

\section{GLORIETTA RIBBON}

A beautiful metalline gauze, exceptionally attractive; ideal for wedding and reception work; all colors to match any flowers. 6 inches wide, 40 yds. to bolt.

Per yd., 61/2c.; 12 bolt lots, 6c. per yd.

\section{SPADE ACE \\ Metalline}

An unusually high grade metalline with attractive border, woven edges; in all the popular colors. Especially adapted for high grade work and will increase the value of any piece. 8 inches wide, 40 yds. to piece.

Per yd., 15c.; 12 piece lots, $141 / 2 \mathrm{c}$. per yd.

\section{PLANTYE}

(Width, Number 5

An unusually attractive ribbon, made in all colors, including tricolor and margined with silver. Where a better grade of pot Premier, Ward, Bermuda, Laurel, Autumn, tie ribbon is required, this number will fill Hyacinth, Hortensia and Goldye. Put up the bill. 50-yd. spools, $75 \mathrm{c}$.; 12 spool lots, in 40-yard pieces.

at $65 \mathrm{c}$ per spool. Purple, Pernet, Nile, Blue, Scarlet, Gray,

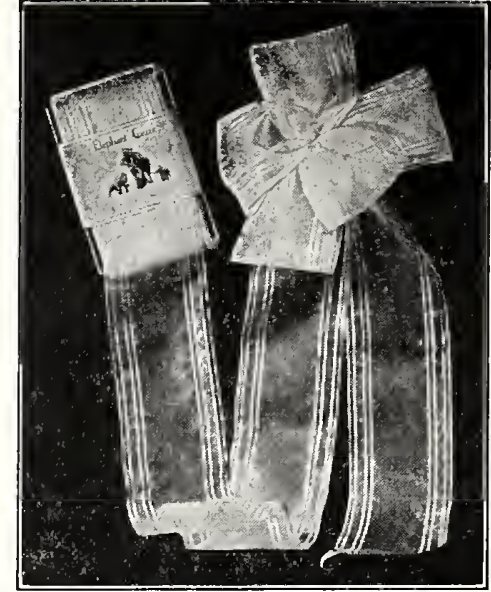

\section{METALLINE OR ELEPHANT} GAUZE

Moisture Proofed by the Allenosgo Process

The most practical Metalline Gauze we have yet seen. It has a beautiful lustre and is so finished it will make a bow that will hold its shape when tied and reach its destination in good condition. Colors: White, Purple, Ward, Gray, Moss and Premier. All pieces on $40-\mathrm{yd}$. bolts. Single piece lots, $51 / 2 \mathrm{c}$. per yd.; 12-piece lots, $5 \mathrm{c}$. per yd.

\section{CHENILLE}

\section{PLAIN WORSTED}

Comes 12 yds. to a piece. Colors: Purple, Red and White. Large size, per piece, 50c.; $\$ 5.50$ per dozen pieces.

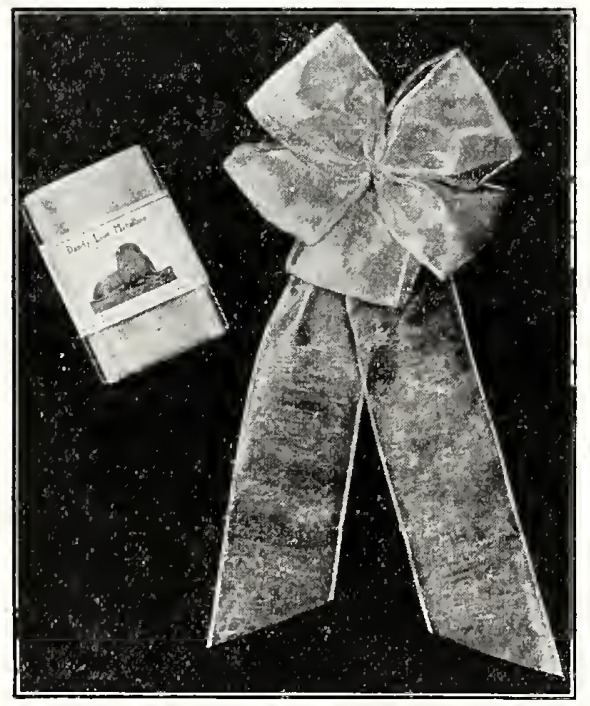

DANDY LION METALLINE Moisture Proofed by the Allenosgo Process

A superior quality, fit for the best work. When the charm of your flowers has faded, the bow remains as a lasting souvenir. Colors: White, Pink, Lavender, Violet, Per yard, 8c.; 12-piece lots, 71/2c. per yd. Pink, Blue, Yellow, Nile, Lavender, Violet,

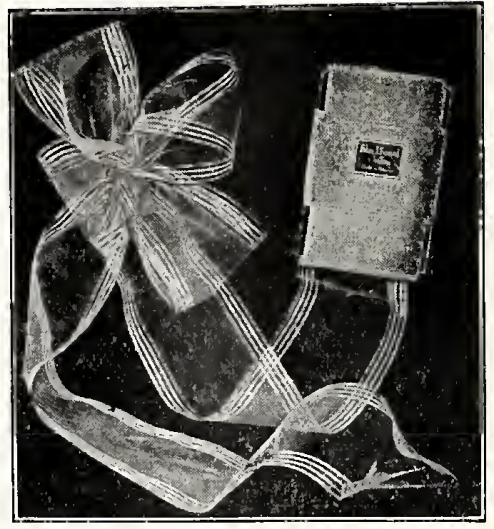

\section{CHIFFON (Blackboard)}

In bolts averaging $40 \mathrm{yds}$. long. White, Pink and Lavender.

4-inch. .......7c. per yd. 61/2c. per yd. 6 -inch...... 8c. per yd. $71 / 2$ c. per yd.

\section{CHIFFON (Lily of the Valley)}

White, Pink and Lavender, with Valley design; width, 6 inches; 40 -yd. pieces only. Per yd., 9c.; 12 piece lots, at $8^{3}{ }_{4}$ c per yd.

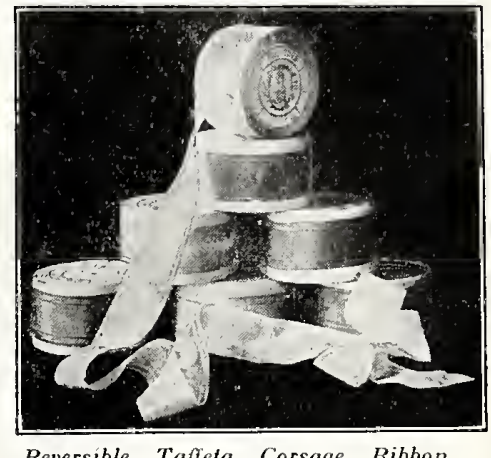

\section{REVERSIBLE TAFFETA CORSA GE RIBBON}

\section{Pattern 3106}

A firm quality of taffeta ribbon that can be used on any quality of corsage. Colors: White, Pink, Blue, Yellow, Nile, Ward, Ophelia, Columbia, Lavender, Violet, Orchid, Bronze and Moss. Put up in 10-yd. bolts; $75 \mathrm{c}$. per bolt; 12 bolt lots, at $70 \mathrm{c}$. per bolt.

\section{NEW IDEA FIBRE}

The finest quality pure silk fibre ribbon; can be used effectively for hours on baskets or plants. Colors: Red, Moss, Green, Lavender, Pink, Purple and White.

No. 5. 1 inch wide; in pieces of $50 \mathrm{yds}$., $\$ 1.30$ per piece; 6 pieces for $\$ 7.50$. 
Our Wire Designs are Carefully and Substantially Made

When ordering please state Number and Size

We make a slight charge at actual cost for packing Wire Designs, on account of the small profit at which they are sold.

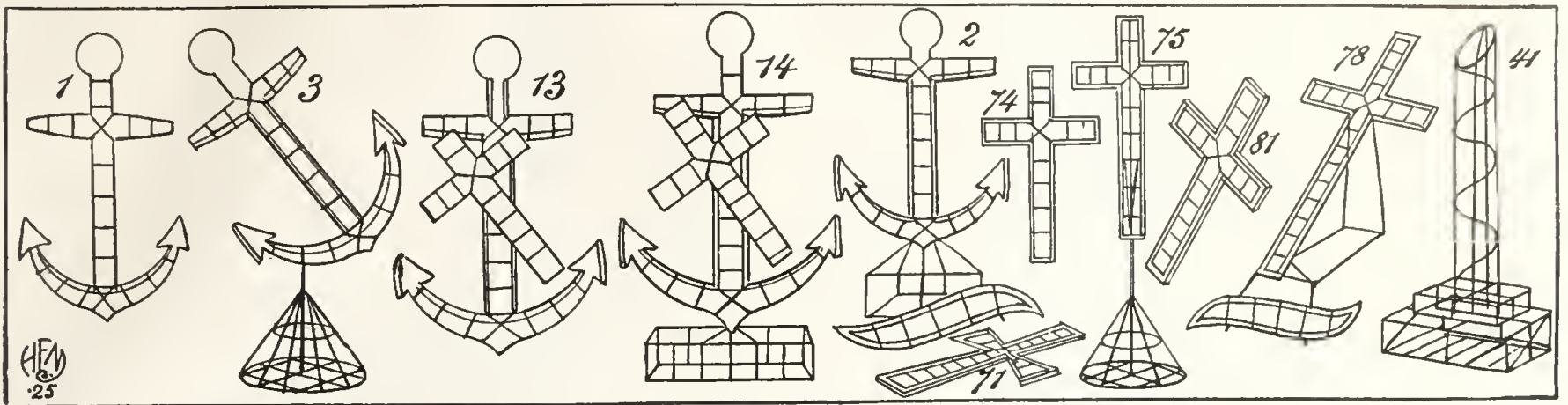

ANCHORS - FLAT

\begin{tabular}{lrrr|rrrr}
\multicolumn{8}{c}{ No. 1} \\
In. & Ea. & \multicolumn{1}{c}{ Doz. } & 25 & In. & Ea. & Doz. & 25 \\
10 & $\$ 0.20$ & $\$ 2.00$ & $\$ 3.75$ & 20 & $\$ 0.45$ & $\$ 4.75$ & $\$ 8.40$ \\
12 & .25 & 2.45 & 4.40 & 22 & .50 & 5.65 & 10.00 \\
14 & .30 & 2.95 & 5.10 & 24 & .60 & 6.60 & 11.80 \\
16 & .35 & 3.40 & 6.10 & 30 & 1.40 & 15.10 & 27.00 \\
18 & .40 & 3.80 & 6.75 & 36 & 2.25 & 23.60 & 42.15
\end{tabular}

ANCHORS ON BASE

No. 3

STANDING ANCHORS

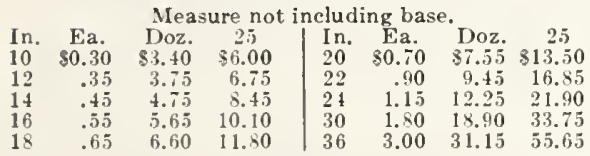

ANCHOR AND CROSS

\begin{tabular}{lrrr|rrrr|} 
& & \multicolumn{1}{c}{ No. 13} & & & \\
In. & Ea. & Doz. & 25 & In. & Ea. & Doz. & 25 \\
12 & $\$ 0.20$ & $\$ 2.25$ & $\$ 4.00$ & 21 & $\$ 0.45$ & $\$ 4.75$ & $\$ 5.45$ \\
15 & .30 & 2.85 & 5.00 & 24 & .55 & 5.65 & 10.10
\end{tabular}

ANCHOR AND CROSS STANDING No. 14

In. Ea. Measure not including base. Doz. 25

\begin{tabular}{lrrr|llll}
12 & $\$ 0.40$ & $\$ 4.15$ & $\$ 7.40$ & 21 & $\$ 0.70$ & $\$ 7.50$ & $\$ 13.50$ \\
15 & .45 & 4.70 & 8.45 & 24 & .90 & 9.45 & 16.85
\end{tabular}

ANCHOR ON RECLINING STAND No. 2

In. Ea. Doz. ${ }^{25}$ In. Ea. Doz. 25 \begin{tabular}{llll|llll}
12 & $\$ 0.55$ & $\$ 5.65$ & $\$ 10.10$ & 20 & $\$ 0.90$ & $\$ 9.45$ & $\$ 16.85$
\end{tabular} \begin{tabular}{llll|llll}
16 & .70 & 7.55 & 13.50 & 24 & 1.50 & 16.00 & 25.70
\end{tabular}

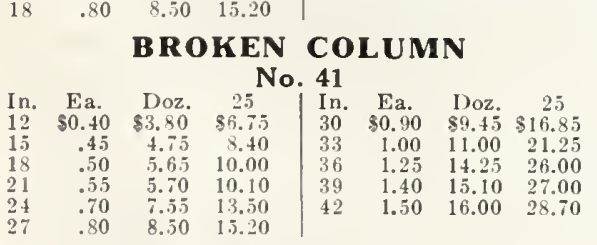

\section{CRESCENT}

\begin{tabular}{rrrr|rrrr} 
& \multicolumn{1}{c}{ No. 58 } & & \\
In. & Ea. & Doz. & 25 & In. & Ea. & 1 Joz. & 2.5 \\
8 & $\$ 0.15$ & $\$ 1.50$ & $\$ 3.70$ & 18 & $\$ 0.40$ & $\$ 3.80$ & $\$ 6.75$ \\
10 & .20 & 1.90 & 3.35 & 20 & .45 & 4.15 & 7.40 \\
12 & .25 & 2.25 & 4.00 & 22 & .50 & 4.70 & 8.45 \\
14 & .30 & 2.85 & 5.00 & 24 & .55 & 5.65 & 10.00 \\
16 & .35 & 3.40 & 5.00 & & & &
\end{tabular}

\section{CROSSES (Flat} No. 74

In,

\section{CROSSES ON STAND}

\begin{tabular}{crrr|rrrr} 
& \multicolumn{7}{c}{ No. $\mathbf{7 5}$} \\
In. & Ea. & Doz. & 25 & In. & Ea. & Doz. & 25 \\
10 & $\mathbf{8 0 . 3 0}$ & $\$ 2.85$ & $\$ 5.00$ & 22 & $\$ 0.70$ & $\$ 7.55$ & $\$ 13.50$ \\
12 & .35 & 3.40 & 6.00 & 24 & 80 & 8.50 & 15.20 \\
14 & .40 & 3.80 & 6.75 & 26 & .90 & 9.45 & 16.85 \\
16 & .45 & 4.70 & 8.45 & 30 & 1.25 & 13.25 & 23.60 \\
18 & .55 & 5.65 & 10.10 & 36 & 1.80 & 18.90 & 33.75 \\
20 & .65 & 6.60 & 11.80 & & & &
\end{tabular}

\section{CROSSES, FLAT SLANTING} No. 81

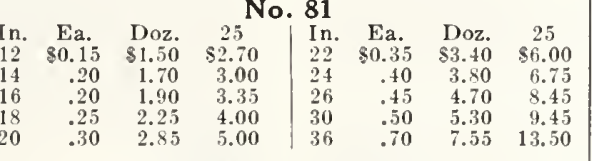

\section{CASKET CROSSES}

No. 71

\begin{tabular}{|c|c|c|c|c|c|c|}
\hline Ea & & 25 & & $F_{2}$ & 107 & \\
\hline$\$ 0.18$ & $\$ 1.90^{\circ}$ & 83.35 & 24 & $\$ 0.45$ & $\$ 4.70$ & 88.45 \\
\hline .20 & $\begin{array}{l}2.25 \\
265\end{array}$ & $\begin{array}{r}4.00 \\
+7\end{array}$ & $\begin{array}{l}26 \\
30\end{array}$ & .50 & $\begin{array}{r}5.30 \\
\end{array}$ & 9.45 \\
\hline .30 & 3.00 & $\begin{array}{l}5.40 \\
5.40\end{array}$ & $\begin{array}{l}30 \\
34\end{array}$ & 70 & $\begin{array}{l}0.02 \\
7.55\end{array}$ & $\begin{array}{l}10.10 \\
13.50\end{array}$ \\
\hline 3 & 3.40 & 6.00 & $\begin{array}{l}37 \\
36\end{array}$ & 80 & 8.50 & 15,20 \\
\hline
\end{tabular}

CROSS ON RECLINING STAND, WITH LETTERING FRAME

\section{No. 78}

In. Ea. Doz. $25 \mid$ In. Ea. Doz. 25 $\begin{array}{llllllll}14 & .60 & 6.60 & 11.80 & 26 & 1.35 & 14.15 & 25.30\end{array}$ $\begin{array}{llllllll}16 & .60 & .6 .60 & 11.80 & 26 & 1.35 & 1.150 & 2.5 .30 \\ 18 & .70 & 7.55 & 13.50 & 28 & 1.55 & 16.00 & 28.70\end{array}$ $\begin{array}{llll}18 & .80 & 8.50 & 13.20\end{array}$

CROSSES (Slanting) AND CROWN In. Ea. Doz. 25 No. 77 In. Ea. Doz. 25 \begin{tabular}{rrrr|rrrr}
21 & $\$ 0.60$ & $\$ 6.60$ & $\$ 11.80$ & 30 & $\$ 0.75$ & $\$ 8.00$ & $\$ 15.00$ \\
24 & .65 & 6.70 & 12.00 & 33 & .85 & 9.00 & 17.75 \\
27 & .70 & 7.55 & 13.50 & 36 & 1.00 & 11.00 & 21.25
\end{tabular}

\section{EASELS}

No. 52

A very pretty Stand for Designs

\begin{tabular}{cccc|ccc} 
In. & Ea. & Doz. & 25 & In. & Ea. & Doz. \\
15 & $\$ 0.15$ & $\$ 1.50$ & 82.70 & 27 & 80.30 & 82.50 \\
15
\end{tabular}

$\begin{array}{llllllll}18 & \$ 0.15 & \$ 1.50 & \$ 2.70 & 27 & 80.30 & 82.50 & \$ 5.00\end{array}$ \begin{tabular}{llll|lllr}
21 & .20 & 2.50 & 3.35 & 30 & .35 & 3.75 & 6.75 \\
1.70 & 36 & .55 & 5.65 & 10.10
\end{tabular}

\section{$\begin{array}{lll}25 & .25 & 2.25 \\ \text { GATES AJAR }\end{array}$}

No. 113. Double Gates Steps and Star, included in measure.

15 inch high, 1 step.

18 inch high, 1 step

21 inch high, 2 steps

24 inch high, 2 steps
27 inch high, 2 steps

27 inch high, 2 steps
30 inch high, 3 steps

33 inch high, 3 steps

HEARTS - OPEN
HEARTS -STANDING

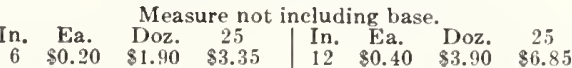
\begin{tabular}{rrrr|rrrr}
8 & .25 & 2.45 & 4.40 & 15 & $\$ 0.40$ & $\$ 3.90$ & $\$ 0.85$ \\
0 & .30 & 2.80 & 5.00 & 15 & .45 & 4.70 & 8.45
\end{tabular} \begin{tabular}{llll|llll}
10 & .30 & 2.80 & 5.00 & 18 & .50 & 5.65 & 10.00
\end{tabular}

PILLO WS - FLA T

No. 169

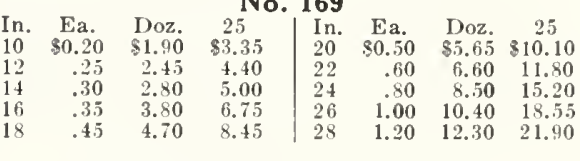

PILLOWS - OPEN TOP No. 170

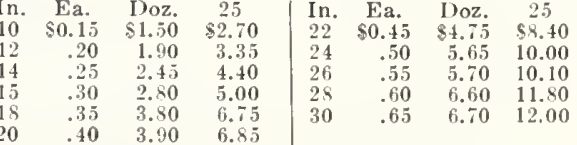

\section{STANDS ON BASES}

No. 202

For the florists who wish to make their own designs. Measure is taken across hottom.

\begin{tabular}{cccc|cccc} 
In. & Ea. & Doz. & 25 & In. & Ea. & Doz. & 25 \\
4 & $\$ 0.10$ & $\$ 0.9 .5$ & $\$ 1.70$ & 10 & $\$ 0.25$ & $\$ 2.45$ & $\$ 4.40$
\end{tabular} $\begin{array}{llllllll}5 & .12 & 1.15 & 2.00 & 12 & .35 & 3.40 & 6.00 \\ 6 & .15 & 1.50 & 2.70 & 14 & .40 & 3.80 & 6.75\end{array}$ \begin{tabular}{llll|llll}
7 & .18 & 1.70 & 3.05 & 16 & .45 & 4.70 & 8.75 \\
8 & .20 & 2.05 & 3.75 & 18 & .50 & 5.70 & 8.45
\end{tabular} \begin{tabular}{llll|l}
9 & .23 & 2.35 & 4.25 &
\end{tabular}

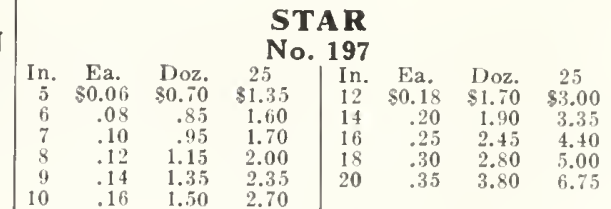

WREATHS

No. 220

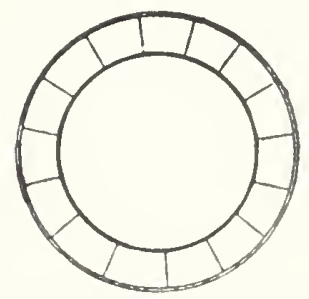

STANDING WREATHS ON STAND No. 226

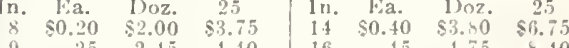




\section{DIRECTIONS FOR USING ANY OF THE FOLLOWING WILL, BE FOUND ON EACH PACKAGE}

PLEASE NOTE.-Insecticides marked * cannot be sent by parcel post. Where others are wanted in this way, add for postage as follows: 10c. for $1 \mathrm{lb}$; $15 \mathrm{c}$. for $2 \mathrm{lbs}$; 20c. for $5 \mathrm{lbs}$; 30c. for $10 \mathrm{lbs}$., up to and including the third zone; for other zones please add additional postage.

*Agri Pax. A contact insecticide which controls rose-bugs as well as soft bodied insects; can be used on currants, asparagus, lettuce, celery, etc. The manufacturers claim it is harmless to plants and is non-poisonous. Per qt., $\$ 1.25 ; \$ 4.00$ per gal.; 5 gals., $\$ 15.00$.

*Antrol A complete control system of combating ants, conThe complete of special glass containers and Antrol syrup. outside of the house or ant trails in the garden. Antrol sets containing 4 containers and one $4-\mathrm{oz}$. bottle of syrup, $95 \mathrm{c}$.; Antrol extra containers, 15c. each; Antrol syrup, 4-oz. bottle, $45 \mathrm{c}$.; 95c. per pt.; gal., $\$ 3.75$.

*Aphine. For destroying aphis, green fly, thrip, red spider and other greenhouse and outdoor insects. It dilutes readily in water about 1 part to 40 of the latter. Per $1 / 4 \mathrm{pt}$., 25c.; $40 \mathrm{c}$. per $1 / 2$ pt.; pt., 65 c.; $\$ 1.00$ per qt.; per gal., $\$ 3.00$.

Aphis Punk. A paper that has been saturated with nicotine for controlling green and black fly and many other forms of insects. Used for fumigating. Especially recommended for destroying many insects injurious to roses, chrysanthemums, sweet peas, smilax and ferns. (For use in greenhouses only.) Per pkg. of 12 sheets, $85 \mathrm{c}$.; $\$ 8.50$ per case of 12 pkgs.

*Aphistrogen. Makes a complete spray for aphis (plant lice) and for most sucking insects; also a plant disinfectant; prepared especially for roses and other plants. Per 4 oz., 70c.; $\$ 1.20$ per $1 / 2 \mathrm{lb}$.; 2 lbs., $\$ 3.25 ; \$ 14.50$ per $12 \mathrm{lbs}$.

*Arsenate of Lead (Coated). Especially valuable for proBeetle, also other insects; covers and sticks like paint Per lb., 50c.; $\$ 1.10$ per $21 / 2$ lbs.; 10 lbs., $\$ 3.25$; $\$ 6.50$ per 25 lbs.; 50 lbs., $\$ 12.00 ; \$ 18.50$ per $100 \mathrm{lbs}$.

*Arsenate of Lead (Powdered). $1 \mathrm{lb}$. to $1 \frac{1}{2} \mathrm{lbs}$. dilutes to 50 gals of water, or may be used dry, like Paris Green. Per lb., 45 c.; $\$ 2.00$ per 5 lbs.; 10 lbs., $\$ 3.75$; $\$ 5.00$ per 25 lbs., $\$ 16.00$ per 100 lbs.

*Arsenate of Calcium. Used for spraying potatoes, cotton, tobacco, etc., against chewing and leaf eating insects; kills quick; sticks to leaves. $1 \mathrm{lb}$. makes 40 to 50 gals. Per $1 / 2 \mathrm{lb}$., 20c.; 30c. per lb.; 5 lbs., $\$ 1.25 ; \$ 2.25$ per $10 \mathrm{lbs} . ; 25 \mathrm{lbs} ., \$ 5.00$; $\$ 18.00$ per 100 lbs.

*Black Leaf 40. Full directions on each package. Per $1 \mathrm{oz}$. bottle, 30c.; $\$ 1.00$ per 5 ozs.; lb., $\$ 2.50$; $\$ 3.75$ per 2 lbs.; 5 lbs., $\$ 7.00 ; \$ 11.85$ per 10 lbs.

*Bordeaux Mixture (Powder). A 12\% copper mixture for spraying purposes. Per lb., 35c.; $\$ 1.60$ per 5 lbs.; 10 lbs., $\$ 2.75$; $\$ 5.50$ per 25 lbs.; 100 lbs., $\$ 20.00$.

Bug Death. Largely used instead of Paris Green. The manufacturers say that it acts as a fertilizer as well as an insecticide; powder form, applied pure. Not poisonous to persons. Per lb., 25c.; 75c. per 5 lbs.; $121 / 2$ lbs., $\$ 1.50 ; \$ 10.00$ per 100 lbs.

Calcium Casenate. Used as a spreader to mix with other insecticides which do not mix readily. - Per $5 \mathrm{lbs}$., $\$ 1.00 ; \$ 1.90$ per 10 lbs.; 25 lbs., $\$ 4.50$.

* Carbolineum. A germicide and disinfectant for purifying poultry houses, stables, etc.; also an excellent wood preserver when used as a paint. Per gal., $\$ 1.40 ; \$ 6.50$ per 5 gals.

* Ceresan (DuBay). For treating the seed of small grains, such as barley, oats, wheat or rye against destructive grain diseases. 2 to 3 ounces are required for one bushel of seed. Per lb., 75c.; $\$ 3.00$ per 5 lbs.; 25 lbs., $\$ 12.50 ; \$ 49.00$ per 100 lbs.

*Copper Solution. Excellent spray for carnation and snapdragon rust and diseases of the grape, pear, apple and other fruits; also for leaf blight and mildew. It is diluted in water. Per qt., $\$ 1.25 ; \$ 3.50$ per gal.

*Cyanegg. For generating Hydrocyanic Acid Gas. Claimed to be the best remedy for killing the white fly. Do not use on Sweet Peas as it destroys them. Per lb., 60c.; $\$ 2.50$ per 5 lbs.

* Cyanogas (Calcium Cyanide). G grade. For fumigating. A valuable insecticide for greenhouse fumigation; eliminates aphis, thrips, white fly or soft scale. Per 5 lbs., $\$ 3.00$; $\$ 10.00$ per 25 lbs.; 100 lbs., $\$ 30.00$.
* Cyanogas (Calcium Cyanide). A grade. For dusting. For Per 1/2 lb., k5c.; 75c. per lb.; 5 lbs., $\$ 3.00$.

*Derrisol For the control of plant lice, leaf hopper, green \$1.25 flies, thrips, red spider, etc. Per 1 oz. bottle, $35 \mathrm{c}$.; $\$ 1.25$ per $1 / 2$ lb. bottle; 1 lb. can, $\$ 2.25 ; \$ 3.25$ per 2 lb. can;
10 lb. can, $\$ 12.00$.

Evergreen Insecticide A non-poisonous insecticide, recominsects on plants and for killing a wide variety of insects on plants and flowers. Per $1 \mathrm{oz} ., 35 \mathrm{c}$.; $\$ 1.00$ per 6 ozs.; 16 ozs., $\$ 2.00$; $\$ 3.50$ per qt.; gal., $\$ 13.00$; $\$ 50.00$ per 5 gals.

Fish Oil Soap. An excellent summer spray, when something stronger cannot be used, where the San Jose Scale exists. It is nice for washing off lemon trees, oleanders, and almost anything that would be infested with soft shelled or in fact most any kind of insect. Dissolved in water according to various purposes. Per lb., 20c.; 80c. per 5 lbs.; $10 \mathrm{lbs} ., \$ 1.50 ; \$ 3.25$ per 25 lbs.; 50 lbs., $\$ 5.00 ; \$ 9.00$ per $100 \mathrm{lbs}$.

Fish Oil Soap (Good's Caustic). This comes in a soft soap form and is easily dissolved, $1 \mathrm{lb}$. to 10 gals. water. Per lb., 20c.; $90 \mathrm{c}$. per 5 lbs.; $10 \mathrm{lbs}$., $\$ 1.65$; $\$ 3.25$ per $25 \mathrm{lbs}$; 50 lbs., $\$ 5.25$; $\$ 9.00$ per 100 lbs.

Fish Oil Soap (Rosin). Especially recommended for the destruction of boxwood maggot, bag worm and caterpillars. Full directions on each package. Per 5 lbs., $\$ 1.25 ; \$ 2.25$ per 10 lbs.; 25 lbs., $\$ 3.75 ; \$ 6.50$ per 50 lbs.; 100 lbs., $\$ 12.00$.

Fume Tobac (for Burning). A high nicotine content tobacco dust, for greenhouse fumigation. Per $25 \mathrm{lbs}$., $\$ 5.25 ; \$ 8.50$ per 50 lbs.; 100 lbs., $\$ 16.00$, f. o. b. Phila. Per 25 lbs., $\$ 5.00 ; \$ 8.00$ per 50 lbs.; 100 lbs., $\$ 15.00$, f. o. b. factory.

*Fungicide (Zenke's). For various forms of fungous diseases. Per 1/2 pt., 30c.; 55c. per pt.; qt., 90c.; $\$ 1.75$ per $1 / 2$ gal.; gal., $\$ 3.25$.

* Fungtrogen A highly concentrated form of fungicide that will conquer mildew and control black spot on roses. It also supplies an essential fertilizer. Dilute 1 part with 60 parts of water. Per $1 / 2$ pt., $70 \mathrm{c}$.; $\$ 1.15$ per pt.; qt., $\$ 1.80 ; \$ 3.25$ per $1 / 2$ gal.; gal., $\$ 5.50$.

Getz There Soap. Ideal for washing palms and spraying in place of Whale Oil Soap. Per 2 lbs., 50c.; $\$ 1.50$ per 8 lbs.; 25 lbs., $\$ 4.00$; bbl. lots, 11c. per lb.

Grape Dust. A powder preparation used for mildew, aphis, black fly and other insects, also for fungous diseases, principally in greenhouse. Per 5 lbs., $85 \mathrm{c}$.; $\$ 1.60$ per 10 lbs.; 25 lbs. $\$ 3.75 ; \$ 13.75$ per $100 \mathrm{lbs}$.

*Hellebore. An ideal material for destroying rose bugs, currant worms and other soft-shelled insects that infest the garden. It can be applied dry or in liquid form. Per $1 / 2 \mathrm{lb} ., 30 \mathrm{c} . ; 55 \mathrm{c}$. per lb.; 5 lbs., $\$ 2.50$.

*Hydroxcide (Mechling's). A combined spray-insecticide and fungicide-kills quickly. Per $1 / 2$ lb., 20c.; 40 c. per lb.; 5 lbs., $\$ 1.60$.

*Insectrogen A complete spray, for leaf-chewing insects, Japanese Beetles; also for black spot mildew and red spider. Per $1 / 2$ pt., 90c.; $\$ 1.60$ per pt.; qt., $\$ 2.50 ; \$ 4.25$ per $1 / 2$ gal.; per gal., $\$ 7.00$.

*Kerosene Emuision (Liquid) (Miscible Oil). Makes an excellent spray for all mild forms of scale and soft lice such as infest rose and fruit bushes, vegetables and trees. Dilutes 1 part to 20 parts of water. Per pt., 45c.; 80c. per qt.; gal., $\$ 1.65$.

*Lemon Oil Insecticide. Used by nearly all the leading growers. It effectually destroys mealy bug, scale, thrip and red spider. Per 1/2 pt., 30c.; 55c. per pt.; qt., 90c.; $\$ 1.65$ per $1 / 2$ gal.; gal., $\$ 2.75 ; \$ 10.50$ per 5 gal. keg.

* Lime Sulphur. For scale insects on trees and shrubs and such fungous diseases as can be treated in winter or early spring; also for leaf curl of peaches. Per qt., $40 \mathrm{c}$.; $\$ 1.00$ per gal.; 5 gals., $\$ 3.60$; $\$ 9.50$ per $1 / 2$ bbl. (30 gals.); bbl. (50 gals.), $\$ 13.00$.

\section{CARBONDALE HYDROMETERS}

For testing the gravity of Lime-Sulphur solution. Price, $\$ 1.00$. (Postpaid, $\$ 1.10$.) With directions. 


\section{MICHELL'S INSECT DESTROYERS, ETC.}

DIRECTIONS FOR USING ANY OF THE FOLLOWING WILL BE FOUND ON EACH PACKAGE

PLEASE NOTE.-Insecticides marked * cannot be sent by parcel post. Where others are wanted in this way, add for postage as follows: 10c. for $1 \mathrm{lb}$; $15 \mathrm{c}$. for $2 \mathrm{lbs}$.; $20 \mathrm{c}$. for $5 \mathrm{lbs}$; $30 \mathrm{c}$. for $10 \mathrm{lbs}$., up to and including the third zone; for other zones please add additional postage.

Lime Sulphur (Dry Powder Form). Instantly soluble in either cold or hot water; dilute $1 \mathrm{lb}$. to $6 \mathrm{gals}$. of water; does not separate, keeps indefinitely. Per lb., 30c.; $\$ 1.30$ per 5 lbs.; 10 lbs., $\$ 2.10 ; \$ 4.25$ per 25 lbs.; 50 lbs., $\$ 7.50 ; \$ 13.00$ per 100 lbs.

Mag-O-Tite Protects crops against the ravages of the root Mag-O-Tite maggot and other garden pests; also eradicates earth worms from lawns, etc.; a valuable stimulant and fertilizer. Per lb., 45c.; $\$ 1.40$ per 5 lbs.; 25 lbs., $\$ 4.50 ; \$ 8.25$ per 50 lbs.

Mexogen. Kills and repels Mexican bean beetles; non-poisonous to humans, animals, or birds, when directions are followed. Per $1 / 2$ pt., 70c.; $\$ 1.90$ per qt.; gal., $\$ 5.75$.

* Mo Lo. A preparation for destroying and driving away moles. per pkg., 22c.; $\$ 2.25$ per doz.

* Nico Fume (Liquid). A modern insecticide for vaporizing and spraying. Per $1 / 4$ lb., $75 \mathrm{c}$.; $\$ 2.00$ per lb.; 4 lbs., $\$ 6.25 ; \$ 11.50$ per 8 lbs. Special contract price on large orders.

*Nico Fume Paper. For fumigating greenhouses, conservatories, etc. Per box of 24 sheets, $\$ 1.25 ; \$ 5.00$ for 144 sheets; 288 sheets, $\$ 8.75$. Special contract price on large orders.

*Nico Fume Fumigating Powder. A $121 / 2 \%$ nicotine fumigator for greenhouse use; burns efficiently and dispenses dense fumes of nicotine; complete with directions in each can. Per $1 \mathrm{lb}$. tin, $\$ 1.00 ; \$ 3.75$ per $5 \mathrm{lb}$. size; $10 \mathrm{lb}$. size, $\$ 6.85$.

*Nikoteen ( $30 \%$ solution). One of the very best forms of tobacco or nicotine preparations; usually diluted in water; makes a most satisfactory spray as well as vapor; excellent for pea lice in the garden. Per 1 oz. bottle, $25 \mathrm{c} . ; \$ 2.50$ per doz.; $40 \mathrm{c}$. per $13 / 1$ oz. bottle; $1 / 2$ lb. bottle, $\$ 1.25 ; \$ 2.00$ per $1 \mathrm{lb}$. bottle; $4 \mathrm{lb}$. bottle, $\$ 6.25 ; \$ 11.50$ per 8 lb. bottle.

*Nikoteen $(40 \%$ solution). Per 4 lbs., $\$ 7.00 ; \$ 13.00$ per 8 lbs.

* Para Dichlorobenzine. For peach tree borers; full directions on each package. Per $1 \mathrm{lb}$. can, 55c.; $\$ 2.25$ per $5 \mathrm{lb}$. can; 10 lb. can, $\$ 3.75 ; \$ 9.00$ per $25 \mathrm{lb}$. keg; $100 \mathrm{lb}$. keg, $\$ 30.00$.

*Paris Green. A poisonous powder for potato bugs, worms, caterpillars, slugs, etc. It may be used in liquid form, 1 pound in 50 gallons of water, or with Land Plaster at the rate of 1 pound Paris Green to 100 pounds Land Plaster. Per $1 / 4$ lb., 13c.; 25c. per $1 / 2$ lb.; lb., 50c.; $\$ 2.25$ per 5 lbs.; 14 lbs., $\$ 4.75$.

Pomo Green or Massey Dust. A leaf green dust for protecting roses and other flowering plants against insects and fungus diseases. Per lb., 45c.; $\$ 1.85$ per 5 lbs.

Pyrethrum Powder. Valuable as a poison for plant lice, water bugs, roaches, etc., also the strawberry moth. Per lb., 60c.; $\$ 2.75$ per 5 lbs.; 10 lbs., $\$ 5.00$.

*Pyrox. A combined insecticide and fungicide for all leaf eating insects, blights and fungous troubles; it is a pasty substance and needs only to be mixed with cold water. Per lb., $45 \mathrm{c}$.; $\$ 1.75$ per 5 lbs.; 10 lbs., $\$ 3.00$; $\$ 6.25$ per 25 lbs.; 50 lbs., $\$ 10.75$; $\$ 15.50$ per 100 lbs.; 300 lbs., $\$ 43.50$.

*Rat Paste (Zelio). The most efficient poison for destroying rats, mice and other rodents. Per $2 \mathrm{oz}$. tube, 50c.

Red Arrow Insect Spray (Pyrethrum Soap). A nonfor use against sucking and chewing insects, such as Japanese beetles, rose chafers, aphids (plant lice), leaf hoppers, Mexican bean beetles, etc., either outdoors or in the greenhouse. Per 1 oz. bottle, $35 \mathrm{c}$.; $\$ 1.00$ per $1 / 1$ pt.; $1 / 2$ pt., $\$ 1.75 ; \$ 6.00$ per qt.; gal., $\$ 20.00$.

* Revivo Controls the Japanese beetle grub, by destroying the grub in the soil; also prevents the growth of crab grass: stunts the growth of chickweed, plantain and dandelion. 10 lbs. will cover a space of 250 square feet. Per $10 \mathrm{lbs} ., \$ 1.50$; $\$ 3.50$ per 25 lbs.; 100 lbs., $\$ 10.00 ; \$ 45.00$ per 500 lbs.

* Scalecide Used for the destruction of the San Jose Scale. Dilute at the rate of one gallon Scalecide to 15 gallons water. Spray during the winter or early spring when the trees are dormant. Per qt., $70 \mathrm{c}$.; $\$ 1.60$ per gal.; 5 gals., $\$ 6.00$; $\$ 10.00$ per 10 gals.; 30 gals., $\$ 24.50$; $\$ 34.00$ per 50 gals.

*Scale Oil. An efficient oil spray for controlling scale insects, aphis, thrip, red spider, etc. Per qt., 70c.; $\$ 1.60$ per gal.; 5 gals., $\$ 6.00 ; \$ 10.00$ per 10 gals.; 30 gals., $\$ 24.50$; $\$ 34.00$ per 50 gals.

* Semesan (DuBay). A mercuric disinfectant for the control of many seed, plant and soil diseases. Per 2 oz., 50c.; $\$ 2.75$ per lb.; 5 lbs., $\$ 13.00 ; \$ 56.25$ per 25 lbs.; $\$ 220.00$ per 100 lbs.

*Semesan Bel (DuBay). For treating seed potatoes before planting, controlling seed borne diseases; $1 \mathrm{lb}$. treats 16 to 20 bushels of seed. Per 4 oz., 50c.; $\$ 1.75$ per lb.; 5 lbs., $\$ 8.00 ; \$ 31.25$ per 25 lbs.; 100 lbs., $\$ 120.00$.
*Semesan, Jr. (Du Bay). For controlling seed borne diseases of seed field and sweet corn; protects the seed from rotting in the ground. Per 4 oz., 50c.; $\$ 1.75$ per lb.; 5 lbs., $\$ 8.00 ; \$ 31.25$ per 25 lbs.; 100 lbs., $\$ 120.00$.

Slug Shot The standard remedy for currant worms, rose nsects that slugs, cabbage worms and almost any soft-shelled carton, 16c.; 55c. per 5 lbs.; 10 lbs., $\$ 1.10 ; \$ 2.65$ per 25 lbs. $100 \mathrm{lbs} ., \$ 10.00$; full barrel lots (about $250 \mathrm{lbs}$.), $91 / 4 \mathrm{c}$. per lb. f. o. b. Philadelphia.

* Snarol For the control of cut worms, snails, slugs, etc.; noninjurious to vegetation and very economical to use on lbs.; 15 lbs., $\$ 3.50$

* Soap Spray (Imp.). An all-around outdoor and greenhouse insecticide. Per pt., 60c.; 85c. per qt.; gal., $\$ 2.75$; $\$ 11.00$ per 5 gals.; 10 gals., $\$ 20.00$.

*Sulphate of Copper. For destroying fungous diseases of all kinds; also used in making Bordeaux mixture, and for spraying potato vines in connection with Paris Green. Per lb., 13c.; 60c. per 5 lbs.; 10 lbs., $\$ 1.10 ; \$ 2.50$ per 25 lbs.; 100 lbs., $\$ 8.50$.

Sulphur. Used principally in greenhouses for checking mildew. It is also used as a preventative and cure for San Jose Scale, when it is used in connection with lime and salt. Per lb., 8c.; 40c. per 5 lbs.; 10 lbs., 75 c.; $\$ 1.75$ per 25 lbs.; 100 lbs., $\$ 6.50$; barrel lots (about $200 \mathrm{lbs}$.), 6c. per lb.

Sulphur Candles. For fumigating in sick rooms, also in conservatories and greenhouses. 12c. each; per doz., $\$ 1.25$.

* Sunoco Spray Oil For the control of scale insects, red ive and pleasant to handle; complete directions with each can. Per gal., $\$ 1.40 ; \$ 5.25$ per 5 gals.; 15 gals., $\$ 10.50 ; \$ 18.00$ per 30 gals.; 50 gals., $\$ 25.00$.

*Thrip Juice (Hammond's No. 2). This preparation is very effective against aphis, red spider, mealy bugs and sucking insects generally. Per pt., 75c.; $\$ 1.25$ per qt.; gal., $\$ 3.50$.

Tobacco Dust (for dusting). Excellent for lettuce and other plants to destroy soft, creeping insects. Per 1 lb. can with sifter top, 20c.; 30c. per 5 lbs.; 10 lbs., 50c.; $\$ 1.00$ per 25 lbs.; 100 lbs., $\$ 3.25 ; \$ 15.00$ per 500 lbs.; $1 / 2$ ton, $\$ 27.50 ; \$ 50.00$ per ton.

Tobacco Dust (for fumigating). A specially prepared article. Per 5 lbs., 40c.; $\$ 1.50$ per 25 lbs.; 50 lbs., $\$ 2.50 ; \$ 4.00$ per 100 lbs.; 500 lbs., $\$ 18.00$.

Tobacco Soap (Sulpho). A combination of tobacco extract and sulphur; fine for washing and spraying plants; dissolve in warm water. 3 oz. pkgs., 90c. per doz.; per 100, $\$ 6.50 ; 6$ oz. pkgs., $\$ 1.50$ per doz.; per $100, \$ 12.00$.

Tobacco Stems (Fresh). Used principally for fumigating and under benches in greenhouse; may also be steeped in hot water and used as a spray. 5 lbs., 25c.; $40 \mathrm{c}$. for $10 \mathrm{lbs}$.; $25 \mathrm{lbs}$., 75c.; large bales at $13 / 4 \mathrm{c}$. per lb.; $1 / 2$ ton, $\$ 12.50 ; \$ 22.50$ per ton.

Tree Tanglefoot A paste preparation for painting around the pillars and other crawling pests cannot form of a band. Cater$55 \mathrm{c}$; $\$ 2.60$ per $5 \mathrm{lb}$. can; $10 \mathrm{lbs}$., $\$ 5.10 ; \$ 10.50$ per $25 \mathrm{lbs}$.

Volck A spray for the garden, nursery and greenhouse; effectively controls red spider, mites, white flies, scales, mealy bugs, caterpillars, aphis, thrips, etc.; not only kills the insects, but also acts as a repellent. Per $1 / 2$ pt., $45 \mathrm{c}$.; 70c. per pt.; qt., 90c.; $\$ 2.75$ per gal.; 5 gals., $\$ 11.50 ; \$ 23.00$ per 10 gals.; 14 gal. drum, $\$ 24.00 ; \$ 37.50$ per 28 gal. drum.

*Wilson's O.K. Plant Spray A powerful yet harmless and red spider, mildew, scale, etc., for inside and outside spraying. Per $1 / 2$ pt., $40 \mathrm{c}$.; $\$ 1.00$ per qt.; gal., $\$ 3.00 ; \$ 12.00$ per 5 gals.; 10 gals., $\$ 20.00$.

Worm Destroyer (for Earth Worms). This is a powder, and is distributed over a given surface and soaked with water, which cause the worms to come to the surface and die where they may be scooped up readily. It also acts as a fertilizer as well as worm destroyer. Per $100 \mathrm{lb}$. bag, $\$ 3.75$; $\$ 17.50$ per 500 lbs.; $1 / 2$ ton, $\$ 30.00 ; \$ 55.00$ per ton.

*X. L. All Insecticide Compound. An English preparation for spraying, harmless to very delicate plants; kills mealy bug, red spider and many other insect pests. Per gal., $\$ 7.00$.

Lamps for Vaporizing Nicotine Solution. 70c. each (by parcel post, 80c.); 6 for $\$ 3.75$ (by parcel post, $\$ 4.00$ ). 
Index to Contents of Michell's Wholesale 1931 Bulb Catalog

SEEDS

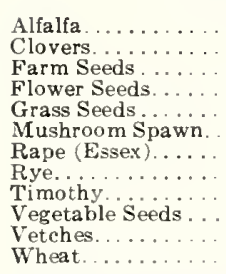

BULBS AND PLANTS

Aconite........
Amaryllis......
Anemone.....
Antirrhinum...
Asparagus Fern

Asparagus Roots.

Azaleas......

Begonias
Bellis Seedlings

Bleeding Heart.

Brodiaeas. .

Calceolarias

Callas

Calochortus.

Camassia.

Chinese Lilies

Chiondoxa...

Cineraria.....

Crassula.

Crocus....

Cyclamen

Daisies.

Diacenas.

Epiphyllum.

Erythronium

Euphorbia......

Ferns......

Freasias.

Gritillaria

Gerbera.

Gladiolus.

Grape Hyacintlis

Hyacinths...

Hydrangeas.

Iris.....

Jonquilis.

Laucoju

Lilies of the Valley

Montbretias.

Myosotis

Ornithogal um

Oxalis

Pandanus.....

Pansy. .

Pelargonium

Peonies.

Perennial Plants

Primula.

Ranunculus.....

Rock Garden Bulbs

Roses...

Scillas.

Scillas......

Smilax.

Snapdragons

Snowdrops.

Spirea.

Tritonia

Tulips.

Vinca.

Zephyranthe

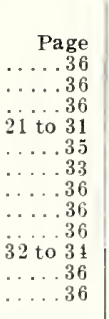

Automobile Heaters.

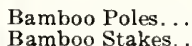

Bark

Baskets.

Bellows.

Birch Bark

Black Leaf 40

Blood (Dried)

Blood Flour

Bone (Coarse Ground)

Bone Flour

Bordeaux Mixture

Bottle Sprayer.

Bouquet Shields.

Bouquet Wire

Boxes.

Broom Rakes.

Brooms.

Bug Death

Bulb Fibre.

Bulb Pans...
Bull Dog Clips

10, 16 Calcium Casenate

Cane Stakes.

Carbolineim

Carnation Dye

Carnation Menders

Carnation Supports

Carton Oak

Cat Tails.

Celery Paper.

Celery Tape. ...

Cel-O-Glas.

Chesan.

Charcoal

iit, 16

Chenille

10, 18

Clay's Fertilizer Manure....3rd Cover

Clock Dials...

Coal for Wagon Heaters

Copper Solution.

Corsage Pins.....

Cottonseed Meal

Cow Manure

Crepe Paper

Crosses

Cut Flower Boxes.

Cut Flower Vases.

Cyanegg.

Cycas Leaves.

Dahlia Stakes.

Derrisol . .

Design Boxes.

.11 Dibbles....

15,12 Driconure.

1, 6,7 Dusters

Evergreen Insecticide

Extension Pipes. .

Feathers

Fern Dish Liners

Ferneries.

Fern Pins.

Ferogen

Fertilizers.

Fibre.

ish Oil Soap

Floranid

Florists' Friend

Flower Baskets

Flower Holders.

Flower Pots.

Flower Vases.

Frieze Roping

Frieze Wreaths..

Fume Tobac. .

Fumigator

Fungtroge

Galax Leaves. . .

Garden Labels.

Gauze

Getz-There Soap

Glass Cleaner

Glass Cutters.

Glazing Cement..

Glazing Chise

Glass Repair Clamps

Glazit Gun

Glazing Point

Grafting Tool

Grafting Wa

Grape Dust.

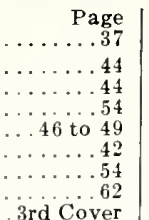

Grass Mats.

Grass Rakes.......

Greening Pins. . .

Handy Handle

Heaters

Hedge Shears

3rd Cover

3rd Cover

3rd Cover

Holly Berries.

Holly Sprays

Horn Sha ving.
Hortobacco.

Hose (Rubber)

Hose Bands.

Hose Connections.

Hose Couplings.

Hose Menders.

Hose Nozzles.

Hose Washers . .

Hotbed Mats.

$\begin{aligned} 4 \text { th Cover } & \begin{array}{l}\text { Hotbed Sash } \\ \text { Hyacinth Glasses } \\ \text { Hyacinth Stakes }\end{array}\end{aligned}$

Hyacinth Stakes.....

Hydrometer

Hydroxcide

Hyper-Humus

Immortelles.

Insectrogen

Insect Destroyers

Japanese Mats .

Jardiers.....

Kainit. .

Kerosene Emulsion

Knives.

Labels.

Land Plaster

Lawn Dressing........... 3rd Cover

Lawn Rakes...

Lawn Sand

Lemon Oil.

Letters.

Lime.

Limestone.

Lime Sulphur

Loma.

3rd Cove

Lopping Shears.

Lotus Pods.

Magnolia Leaves.

Mag-O-Tite

Manure.

Marking Pencils .

Mastica

Mastica Machine

Masticote

Mats

Metalline

Mexogen

Moon Blossoms

Moss.

Mum Manure

Muriate of Potash

Nico Fume

Nico Fume Paper

Nico Fume Tobacco Powder

Nitrate of Soda . . . . . . . . . 3 r Cover

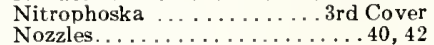

Oak Leaf Sprays.

O. K. Plant Spray

Orchid Peat

Paper.

Paper Flower Pots

Para-Dichlorobenzine

Paris Green
Pearl Chips

Peat

Peat Moss

Pebbles.

Philogan

Phosphate.

Pine Cones.

Plantabbs.

Plant Stakes

Plant Stands.

Plant Tie.

Plantye.

Plaster

Poinsettias.

Poles.

Pomo Green

Poppy Heads.

Pot Hangers.

Pot Labels.

Pot L.

Protecting Cloth

Protecting Cloth.....
Pruning Compound

Pruning Gloves

Page

Pruning Saws. ...

Pruning Shears

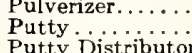

Putty Distributor...
Pyrethrum Powder

Pyrethrum Powder.

Raffia

Raffia Tape................ 43

Rat Paste.................

Red Arrow Insect Spray

Revivo.

Road Brushes

Rubber Apron

Rubber Sprinklers

Ruscus

Salt

Sand

Saucer

Saws.

Scalecide

Scale Oil......

Seed Pans

Shaderine.

Shading Cloth. .

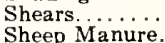

Sheep

Sieves...

Snapdragon Supports

Snaro

Soap Spray

Soil Pulverizer

Soot.

Spade Ace.

Sprayers.

Stake Fasteners.

Star Forms. 
From

Post Office

MICHELL'S SEED HOUSE 518-516 MARKET STREET 


\section{DON'T FORGET TO WRITE}

YOUR

NAME AND ADDRESS 
PLEASE NOTE.-No smaller quantity of Fertilizer than here offered can be supplied.

Acid or Rock Phosphate (16\%). Apply 1,000 lbs. per acre. 200 lbs., $\$ 3.00 ; \$ 11.50$ per $1 / 2$ ton; ton, $\$ 20.00$.

Adco. A bacterial food for making artificial manure with leaves, grass cuttings, etc. Per 25 lbs., sufficient to make one-half ton of manure, $\$ 1.75 ; \$ 10.00$ per 150 lbs.; 600 lbs., $\$ 40.00 ; \$ 138.00$ per 2,100 lbs.

Ashes, Canada Hard Wood. Apply 1,000 lbs. per acre. Per 25 lbs., 85c.; $\$ 1.50$ per 50 lbs.; 100 lbs., $\$ 2.50 ; \$ 4.25$ per 200-lb. bbl.; $1 / 2$ ton, $\$ 18.00$; per ton, $\$ 35.00$.

Blood (Dried). For indoor culture of flowering plants like roses, carnations, etc. 5 lbs., 50c.; 80c. per 10 lbs.; 25 lbs., $\$ 1.75$; $\$ 3.00$ per 50 lbs.; 100 lbs., $\$ 5.50 ; \$ 10.00$ per 200 lbs.; 500 lbs., $\$ 22.50 ; \$ 42.50$ per $1 / 2$ ton; ton, $\$ 80.00$.

Blood Flour. Similar to dried blood. $\$ 6.00$ per $100 \mathrm{lbs}$; 200 lbs., $\$ 11.00 ; \$ 50.00$ per $1 / 2$ ton; ton, $\$ 95.00$.

Bone (Coarse Ground). Apply 800 to $1,000 \mathrm{lbs}$., per acre. 200 lbs., $\$ 7.00 ; \$ 32.50$ per $1 / 2$ ton; ton, $\$ 60.00$.

Bone Flour. 25 lbs., $\$ 1.25$; $\$ 2.25$ per 50 lbs.; 100 lbs., $\$ 4.00$; $\$ 7.00$ per 200 lbs.; $1 / 2$ ton, $\$ 32.50 ; \$ 60.00$ per ton.

Bone Meal (Michell's Special Florist's Brand). Apply 800 to 1,000 lbs. per acre. 3 lbs., 20c.; 30c. per 5 lbs.; 10 lbs., 55c.; $\$ 1.15$ per 25 lbs.; 50 lbs., $\$ 2.00$; $\$ 3.50$ per 100 lbs.; 200 lbs., $\$ 6.00$; $\$ 27.50$ per $1 / 2$ ton; ton, $\$ 50.00$.

Chrysanthemum Manure (Thompson's Special). Per 28-lb. sack, $\$ 3.50 ; \$ 6.25$ per 56 -lb. sack.

Clay's Fertilizer. An English chemical fertilizer for forcing greenhouse plants and vegetables. $28 \mathrm{lbs}$., $\$ 3.25 ; \$ 5.50$ per 56 lbs.; 112 lbs., $\$ 10.00$.

Cotton Seed Meal. Apply 800 lbs. per acre. 5 lbs., 30c.; 55c. per 10 lbs.; 25 lbs., $\$ 1.15 ; \$ 2.00$ per 50 lbs.; 100 lbs., $\$ 3.50$; $\$ 31.50$ per $1 / 2$ ton; ton, $\$ 60.00$.

Cow or Cattle Manure (Pulverized or Shredded). 'Thoroughly sterilized and weedless. In 100-lb. bags f. o. b. Philadelphia, $\$ 3.50$ per 100 lbs.; 500 lbs., $\$ 16.00 ; \$ 27.50$ per $1 / 2$ ton; ton, $\$ 52.50$.

Cow or Cattle Manure. F. o. b. Chicago, 100 lbs., $\$ 2.50 ; \$ 9.00$ per 500 lbs.; $1 / 2$ ton, $\$ 17.00 ; \$ 32.00$ per ton.

Driconure. A desirable lawn and garden top dressing and soil conditioner. 50 lbs., $\$ 2.50$.

Ferogen. A spring and summer ground dressing. Per lb., 65c.; $\$ 1.15$ per 2 lbs.; 5 lbs., $\$ 2.50 ; \$ 10.00$ per 25 lbs.; 100 lbs., $\$ 37.00$.

Floranid. A concentrated organic nitrogen fertilizer; $1 / 2 \mathrm{lb}$. is sufficient to treat 100 square feet of ground. Per lb., 45c.; $\$ 1.90$ per 5 lbs.; 10 lbs., $\$ 2.90 ; \$ 4.75$ per 25 lbs.

Horn Shavings. Used principally for mixing in potting soil. 5 lbs., 55c.; $\$ 1.00$ per 10 lbs.; 25 lbs., $\$ 2.00 ; \$ 3.50$ per 50 lbs.; 100 lbs., $\$ 6.50 ; \$ 12.00$ per 200 lbs.

Hortobacco (Michell's). A complete combined fertilizer and insecticide. 5 lbs., 25c.; 40c. for 10 lbs.; 25 lbs., 90 c.; $\$ 1.60$ per 50 lbs.; 100 lbs., $\$ 2.75 ; \$ 12.50$ per 500 lbs.; $1 / 2$ ton, $\$ 23.50 ; \$ 45.00$ per ton, f. o. b. Phila. ( $\$ 40.00$ per ton, f. o. b., Lancaster.)

Hyper-Humus. Especially desirable for mixing with potting soil. 5 lbs., 25c; 40c. per 10 lbs.; 25 lbs., 75c.; $\$ 1.25$ per 50 lbs.; 100 lbs., $\$ 2.00 ; \$ 8.00$ per 500 lbs.; $1 / 2$ ton, $\$ 13.00 ; \$ 22.50$ per ton. Carload lots in bulk, $\$ 9.00$ per ton, f. o. b. factory.

Kainit (Potash Salts). Apply 800 to 1,000 lbs. per acre. $5 \mathrm{lbs}$., 25 c.; 40 c. per 10 lbs.; 25 lbs., 75 c.; $\$ 1.35$ per 100 lbs.; 200 lbs., $\$ 2.50 ; \$ 11.00$ per $1 / 2$ ton; ton, $\$ 20.00$.

Land Plaster. Apply about 1,500 to 2,000 lbs. per acre. Per 25 lbs., 60c.; $\$ 1.00$ per 50 lbs.; 100 lbs., $\$ 1.75 ; \$ 3.00$ per 200 lbs.; per $1 / 2$ ton, $\$ 13.50 ; \$ 25.00$ per ton.

Lawn Sand (Climax). A weed destroyer as well as a fertilizer. $31 / 2$-lb. tin, 65 c.; $\$ 1.25$ per 7 lbs.; 14 lbs., $\$ 2.25 ; \$ 3.75$ per 28 lbs.; 56 lbs., $\$ 6.00 ; \$ 11.50$ per 112 -lb. bag.

Lime (Hydrated or Powdered). 40c. per 10-lb. box.; 50 lbs., $\$ 1.00$; $\$ 1.75$ per 100 lbs.; 500 lbs., $\$ 7.00 ; \$ 13.00$ per $1 / 2$ ton; ton, $\$ 23.00$.

Limestone (Pulverized). Apply 1 ton per acre. Per 100-lb. bag, $\$ 1.75 ; \$ 6.50$ per 500 lbs.; $1 / 2$ ton, $\$ 11.00 ; \$ 20.00$ per ton.

Loma. A scientifically prepared plant food for lawns, flower gardens, vegetable gardens, shrubbery and potted plants; rich in life-giving nitrogen, also potash and phosphates. Per lb., 25c.; 50c. per 5 lbs.; 10 lbs., 85c.; $\$ 1.75$ per 25 lbs.; 50 lbs., $\$ 3.00 ; \$ 5.00$ per 100 lbs.

Michell's Lawn Dressing and Fertilizer. Apply 1,000 lbs. per acre. Per 5 lbs., $30 \mathrm{c}$; $50 \mathrm{c}$. per 10 lbs.; 25 lbs., $85 \mathrm{c} . ; \$ 1.50$ per 50 lbs.; 100 lbs., $\$ 2.75 ; \$ 25.00$ per $1 / 2$ ton; ton, $\$ 45.00$.

Mum Manure (Smith's). A perfect food for Mums and other flowers, either under glass or in the garden. Per 100 lbs., $\$ 3.75 ; 500$ lbs. or over, at $\$ 3.50$ per $100 \mathrm{lbs}$.
Muriate of Potash. Apply 100 to $150 \mathrm{lbs}$. per acre, usually with other fertilizers. 5 lbs., $30 \mathrm{c}$.; $50 \mathrm{c}$. per 10 lbs.; 25 lbs., $\$ 1.00$; $\$ 2.00$ per 50 lbs.; 100 lbs., $\$ 3.75 ; \$ 7.00$ per 200 lbs.; $1 / 2$ ton, $\$ 31.50 ; \$ 60.00$ per ton.

Nitrate of Soda. Apply 100 to $150 \mathrm{lbs}$. per acre, mixing with land plaster or other fertilizers to render application more easy. Use only after plants are above ground. 5 lbs., $40 \mathrm{c}$.; $75 \mathrm{c}$. per 10 lbs.; 25 lbs., $\$ 1.35 ; \$ 2.50$ per 50 lbs.; 100 lbs., $\$ 4.50 ; \$ 8.50$ per 200 lbs.; $1 / 2$ ton, $\$ 39.00 ; \$ 75.00$ per ton.

Nitrophoska. A well-balanced, quick acting food for all purposes in the garden or lawn. Analysis: Nitrogen, 15\%; Phosphoric Acid, $30 \%$; Potash, $15 \%$. Lb., 45c.; $\$ 1.90$ per 5 lbs.; 10 lbs., $\$ 2.90 ; \$ 4.75$ per 25 lbs.; 100 lbs., $\$ 8.00$.

Philogan. A natural manure for all crops. Organic material, manufactured by scientific process; no waste, all available, absolutely safe; the ideal food for carnations, roses, sweet peas, etc. 100 lbs., $\$ 2.00 ; \$ 19.00$ per $1 / 2$ ton; ton, $\$ 35.00$.

Phosphate, Michell's High Grade. Apply 800 to $1,000 \mathrm{lbs}$. per acre broadcast. 5 lbs., $25 \mathrm{c}$.; $45 \mathrm{c}$. per 10 lbs.; 25 lbs., $\$ 1.00$; $\$ 1.75$ per 50 lbs.; 100 lbs., $\$ 3.00 ; \$ 5.25$ per $200 \mathrm{lbs}$; $1 / 2$ ton, $\$ 23.75 ; \$ 45.00$ per ton.

Plantabbs. An odorless plant food in tablet form, for all plants in the house or garden. Pkgs. of 30 tablets, $\$ 2.00$ per doz.; pkgs. of 75 tablets, $\$ 4.00$ per doz.; pkgs. of 200 tablets, $\$ 8.00$ per doz.; can of 1,000 tablets, $\$ 28.00$ per doz.

Salt. For agricultural purposes. Apply 800 lbs. per acre. 100 lbs., $\$ 1.50 ; \$ 2.75$ per 200 lbs.; $1 / 2$ ton, $\$ 12.00 ; \$ 22.00$ per ton. Sheep Manure (Wizard Brand). Apply 1,000 lbs. per acre. 25c. per 3 lbs.; 5 lbs., 35c.; 60c. per 10 lbs.; 25 lbs., $\$ 1.00 ; \$ 1.80$ per 50 lbs.; 100 lbs., $\$ 3.50 ; \$ 16.00$ per 500 lbs.; $1 / 2$ ton, $\$ 27.50$; $\$ 52.50$ per ton.

Sheep Manure (Wizard Brand). F. o. b. Chicago. For our western and southwestern customers shipment can be made from Chicago at considerable saving in freight charges. 100 lbs., $\$ 2.50 ; \$ 9.00$ per 500 lbs.; $1 / 2$ ton, $\$ 17.00 ; \$ 32.00$ per ton. Soot (Imported Scotch). 5 lbs., 60c.; $\$ 1.00$ per 10 lbs.; 25 lbs., $\$ 1.75$; in sacks of about 100 lbs., $4 \mathrm{c}$. per lb.; 5-sack lots, at $31 / 2$ c. per lb.

Stimugerm. A pure culture of nitrogen-fixing bacteria for inoculating all leguminous crops. Special garden size, for Garden Peas, Beans and Sweet Peas, $25 \mathrm{c}$. For Alfalfa and all Clovers,
$1 / 4 \mathrm{bu}$. size, $35 \mathrm{c}$.; $1 / 2$ bu. size, $60 \mathrm{c}$; 1 bu. size, $\$ 1.00 ; 21 / 2$ bu. size, $\$ 2.25$. For Cow Peas, Soy Beans, Canada Peas, Vetch, Beans, Peas and Sweet Peas, $1 / 2$ bu. size, $35 c_{\text {. }} ; 1$ bu. size, $60 \mathrm{c} . ; 2$ bu. size, $\$ 1.10 ; 5$ bu. size, $\$ 2.25$.

Stim-U-Plant. A plant food in tablet form. Per pkg. of 30 tablets, 25c.; 75c. per pkg. of 100 tablets; 1,000 tablets, $\$ 3.50$.

Sulphate of Ammonia. Apply 75 to 100 lbs. per acre only with other fertilizers deficient in nitrogen. Analysis: equal to $25 \%$ of ammonia. 5 lbs., 60c.; $\$ 1.00$ per 10 lbs.; 25 lbs., $\$ 1.65$; $\$ 2.75$ per 50 lbs.; 100 lbs., $\$ 4.75 ; \$ 8.50$ per 200 lbs.

Sulphate of Potash. Apply 100 to $125 \mathrm{lbs}$. per acre, usually with other fertilizers. Analysis: Equal to $50 \%$ of actual potash. 5 lbs., 35c.; 60c. per 10 lbs.; 25 lbs., $\$ 1.25 ; \$ 2.25$ per 50 lbs.; 100 lbs., $\$ 4.25$; $\$ 7.75$ per 200 lbs.

Tankage. This is usually applied to plants such as roses, etc., under glass. 5 lbs., 30c.; 50c. per 10 lbs.; 25 lbs., $\$ 1.00 ; \$ 1.75$ per 50 lbs.; 100 lbs., $\$ 3.25 ; \$ 6.00$ per 200 lbs.; $1 / 2$ ton, $\$ 28.00$; $\$ 55.00$ per ton.

Terogen. A new autumn and winter ground dressing, acting both as a fertilizer and an insecticide. Lb., $65 \mathrm{c}$.; $\$ 1.15$ per 2 lbs.; 5 lbs., $\$ 2.50 ; \$ 4.50$ per 10 lbs.; 25 lbs., $\$ 10.00 ; \$ 37.50$ per 100 lbs.

Tobacco Stems. 5 lbs., 25c.; 40c. per 10 lbs.; 25 lbs., 75 c.; bale lots at $13 / 4$ c. per lb.; $1 / 2$ ton, $\$ 12.50 ; \$ 22.50$ per ton.

Tree Food, Evergreen (Michell's). A wonderful fertilizer for fruit and shade trees. 25 lbs., $\$ 1.50 ; \$ 2.75$ per 50 lbs.; 100 lbs., $\$ 5.00 ; \$ 20.00$ per $500 \mathrm{lbs}$; $1 / 2$ ton, $\$ 36.00 ; \$ 70.00$ per ton.

Velvet Lawn Fertilizer (Sulphate of Ammonia). For lawns, golf courses, truck gardens, small fruits, orchards, shrubs, house plants and wherever quick, luxurious, weedless vegetation is wanted. 26 oz. carton, 20c.; 55c. per 5 lbs.; 10 lbs., $\$ 1.00$; $\$ 2.00$ per 25 lbs.; 50 lbs., $\$ 3.00 ; \$ 4.50$ per 100 lbs.

Vigoro. Especially adapted for the lawn and vegetable garden. 5 lbs., 50c.; $\$ 1.75$ per 25 lbs.; 50 lbs., $\$ 3.00 ; \$ 5.00$ per 100 lbs.

Wheat Fertilizer. For grass and grain crops. Apply $800 \mathrm{lbs}$. per acre. $\$ 4.50$ per 200 lbs.; $1 / 2$ ton, $\$ 21.00$; $\$ 40.00$ per ton.

Wonder Worker Fertilizer. A high grade animal base fertilizer, for growing all vegetable crops. Per $100 \mathrm{lbs}$., $\$ 5.00 ; \$ 9.00$ per 200 lbs.; 500 lbs., $\$ 22.00 ; \$ 35.00$ per $1 / 2$ ton; ton, $\$ 65.00$. 


\section{MICHELL'S FLOWER POTS, TUBS, ETC.}

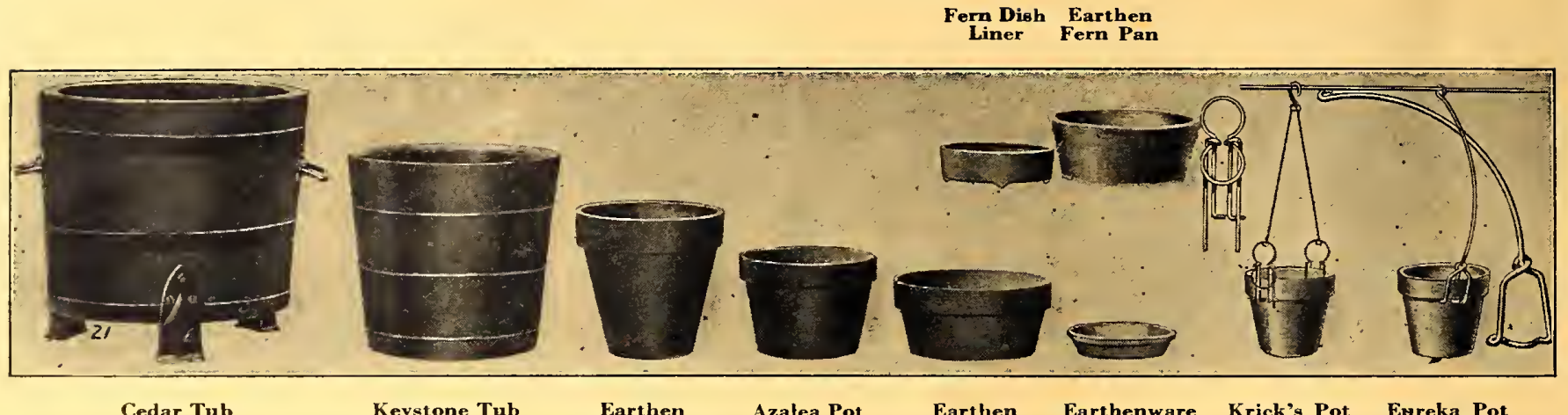

Cedar Tub

Earthen
Flower Pot

Hanger Eureka Pot

\section{CEDAR TUBS}

Equipped with Strong Iron Hoops

These are made by hand, of the very best white cedar, painted green. All measurements are inside.

No. 0......243/in. 24 in. $\$ 11.00$

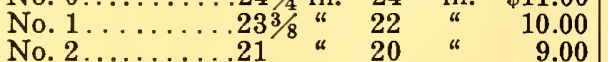

No. $2 \ldots \ldots .21$ ". 20

No. $4 \ldots \ldots \ldots \ldots 16 \frac{16}{2}$ " 16

No. $5 \ldots \ldots \ldots \ldots 14 \frac{7}{16}$ " 14

$\begin{array}{ll}\text { No. } 6 \ldots \ldots \ldots 12 \frac{7}{16} \text { " } & 12 \\ \text { No. } 7 \ldots \ldots \ldots 11 \% 4 & 10\end{array}$

No. 8 .

$10 \frac{11}{16}$

9.00
7.25
6.00

6.00
5.25

4.50
4.00

4.00
3.50
NEPONSET BLACK PAPER POTS

\section{For Growing}

This new development makes it possible to take advantage of the economy, ease and convenience of paper pots for the full growing period of young plants without any damaging or retarding of root growth. The special water-proofing treatment of these pots seems to encourage healthy growth; not 9.00 necessary to use clay pots.

\section{MICHELL'S KEYSTONE TUBS}

Made of white cedar, painted green and bound with strong wire hoops. Handles are sold separately at $25 \mathrm{c}$. per pair.

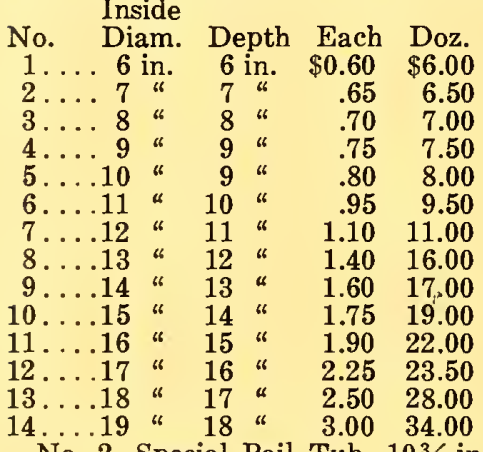

100
$\$ 45.00$
46.50
48.00
49.50
60.00
72.00
87.00
100.00

-in. deep. Per doz., $\$ 8.50 ; \$ 65.00$ per 100 .

\section{AZALEA POTS}

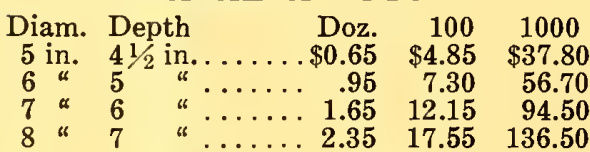

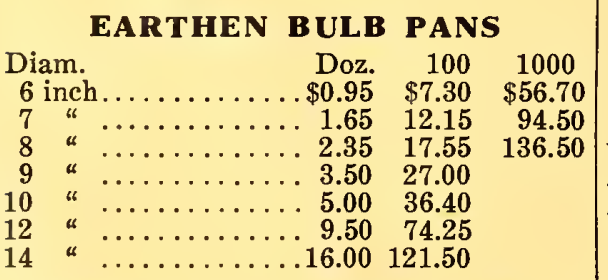

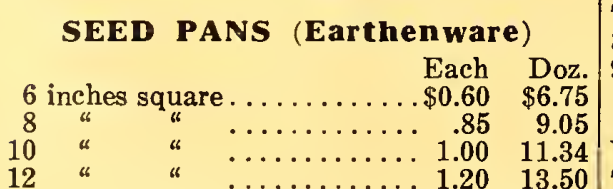

$\begin{array}{ccc}\text { Size } & \begin{array}{c}\text { Weight } \\ \text { per } \\ 1000\end{array} & \begin{array}{c}\text { Price } \\ \text { per } \\ 1000\end{array} \\ 1 / 2 \text { inch } \ldots \ldots \ldots \ldots \ldots \ldots \ldots 22 \text { lbs. } & \$ 5.00 \\ \text { inch } \ldots \ldots \ldots \ldots \ldots \ldots 28 \text { lbs. } & 7.00 \\ \text { inch } \ldots \ldots \ldots \ldots \ldots \ldots 2 \text { lbs. } & 11.00\end{array}$
Special prices will be quoted f. o. b. factory.

\section{EARTHEN FLOWER POTS}

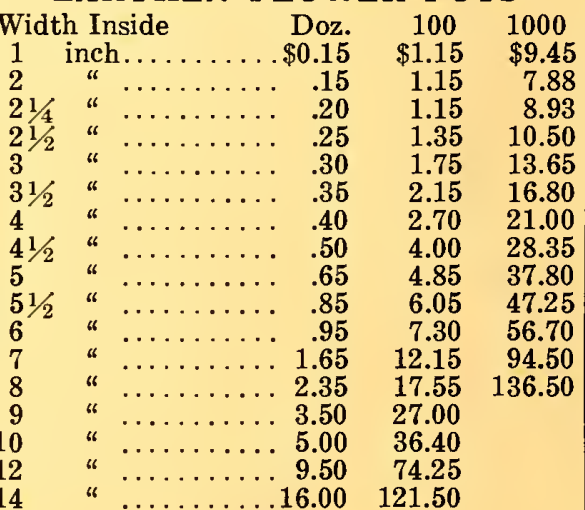

$\mathbf{E}$

Diam.

AARTHENWARE SAUCERS

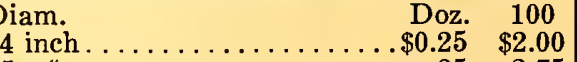

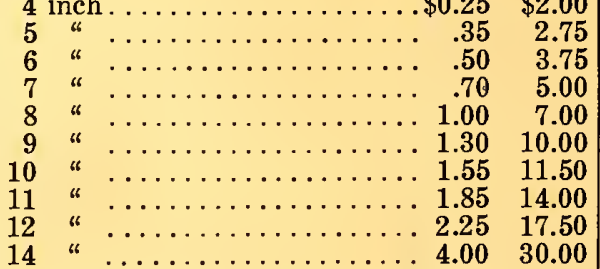

EARTHEN FERN PANS

Width Height Each Doz. 100 4 in. $17 / 8$ in. . . . . \$0.05 $\$ 0.50 \quad \$ 4.00$ $43 / 4$ \& $21 / 8$ \& $\ldots \ldots \ldots .08 \quad .08 \quad .70 \quad 5.00$ $51 / 2$ " $21 / 4$ " $\ldots \ldots \ldots . .10 \quad .85 \quad 6.25$ $61 / 4$ " $21 / 2$ " $\ldots . . .6 .12 \quad 1.00 \quad 7.50$

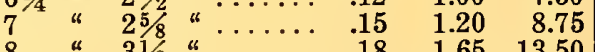

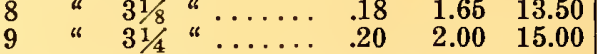

\section{FERN DISH LINERS}

Depth $17 / 8$ in \begin{tabular}{ccc|c} 
Each & Doz. & 100 & 16 \\
$\$ 0.15$ & $\$ 1.56$ & $\$ 11.88$ & 18
\end{tabular}

\section{POT HANGERS}

P. Post

to 5 in. pots.. $\$ 0.06 \quad \$ 0.55 \quad \$ 0.65 \quad \$ 4.75$

$\begin{array}{lllll}\text { Krick's No. 2, } 6 & & & & \\ & & \end{array}$

$\begin{array}{ccccc}\text { and } 7 \text { in.pots. } & .07 & .65 & .75 & 5.00\end{array}$

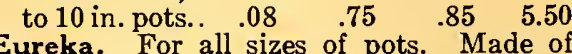

Eureka. For all sizes of pots. Made of
galvanized wire. 12c. each; per doz., $\$ 1.25$ (by P. P., \$1.35); $\$ 9.00$ per 100 .

\section{PAPER FLOWER POTS}

\section{Weight Per P. Post}

per $1000 \quad 100$ per $100 \quad 1000$

$\begin{array}{lllll}2 & 10 \mathrm{lbs} . & \$ 0.38 & \$ 0.48 & \$ 3.40\end{array}$

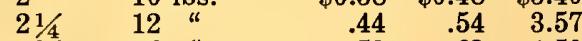

$\begin{array}{llllll}21 / 2 & 16 & & .44 & .54 & 3.57 \\ 3 & 24 & & .52 & .62 & 4.50\end{array}$

$\begin{array}{llllll}3 & 24 & \text { " } & .70 & .85 & 6.09 \\ 31 & 34 & & .71 & 1.06 & 7.82\end{array}$

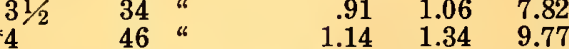

\begin{tabular}{llllll}
$* 5$ & 74 & " & 1.77 & 2.02 & 15.07 \\
\hline & 102 & & 1.37 & 2.67 & 20.05
\end{tabular}

$\begin{array}{llllll}* 6 & 102 & \text { * } & 2.37 & 2.67 & 20.05\end{array}$

130 " $\quad 2.95 \quad 3.25 \quad 24.75$

Sizes marked * are packed 500 to a crate, other sizes 1000 . Special price will be quoted on paper pots f. o. b. factory.

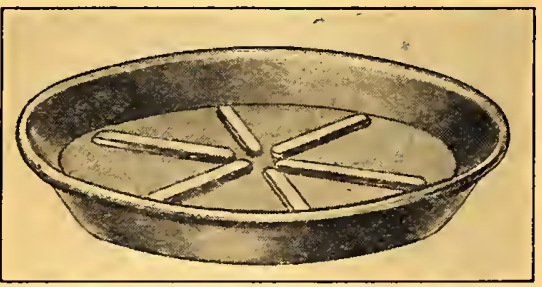

RUBBER SAUCERS

Durable and waterproof.

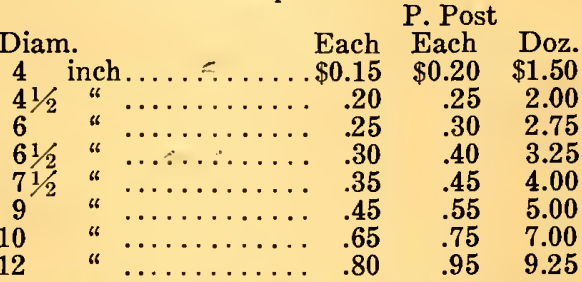

WOOD FIBRE SAUCERS Outside

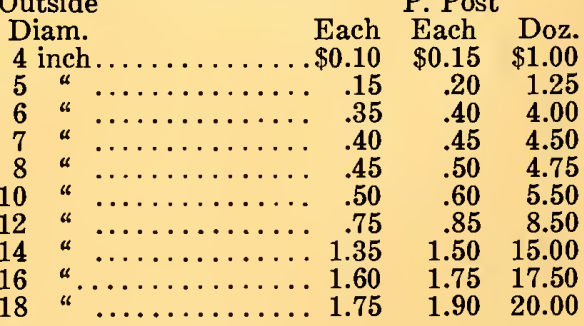

